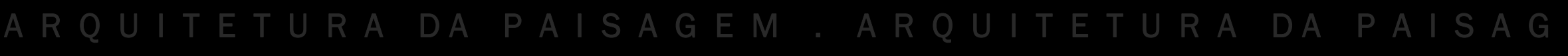
EM. ARQUITETURA DA PAISAGEM. ARQUITETURA DAPA

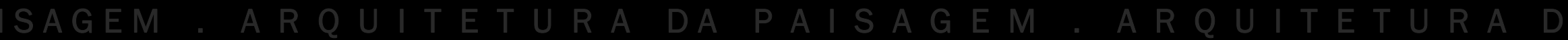
A PAISAGEM:ARQUITETURA DA PAISA G M : ARQUITETUR

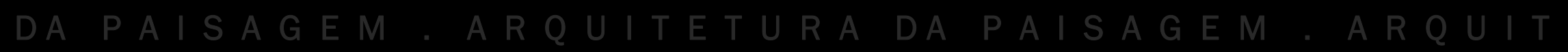

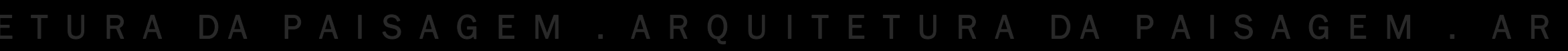
QUVTETURA DAPAISAGEM.ARQUITETURA DAPAISAGE A R Q U TETURA DA PAISA G E M A R U I T T U R A D PA I

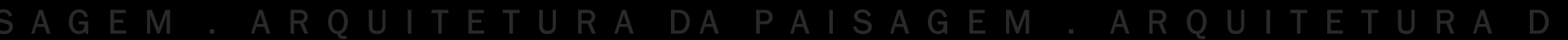
A PAISAGEM:ARQUITETURA DAPAISAGEM. ARQUITET URA DA PAISAGEM.ARQUITETURA DAPAISAGEM. A R Q TETURA DA PAISAGEM . AR Q U I TE T URA DA PAISA G M entre o Pinturesco, OImsted e o Moderno

$\begin{array}{llclrr}\text { I u ciana bongiovanni martins schenk } \\ \text { UNIVERSIDADE } & \text { DE } & \text { SÃO } & \text { PAULO } \\ \text { ESCOLA DE } & \text { ENGENHARIA } & \text { DE } & \text { SÃO } & \text { CARLOS } \\ \text { DEPARTAMENTO } & \text { DE } & \text { ARQUITETURA } & \text { E } & \text { URBANISMO }\end{array}$




\section{ARQUITETURA DA PAISAGEM - entre o Pinturesco, Olmsted e o Moderno}

TESE DE DOUTORADO

Luciana Bongiovanni Martins Schenk

Orientador

Prof. Dr. Carlos Roberto Monteiro de Andrade

Tese de Doutorado apresentada à Escola de Engenharia de São Carlos da Universidade de São Paulo, Departamento de Arquitetura e Urbanismo, como parte dos requisitos para a obtenção do título de Doutor em Arquitetura e Urbanismo.

São Carlos . junho de 2008 
AUTORIZO A REPRODUÇÃO E DIVULGAÇÃO TOTAL OU PARCIAL DESTE

TRABALHO, POR QUALQUER MEIO CONVENCIONAL OU ELETRÔNICO,

PARA FINS DE ESTUDO E PESQUISA, DESDE QUE CITADA A FONTE.

Ficha catalográfica preparada pela Seção de Tratamento

da Informação do Serviço de Biblioteca - EESC/USP

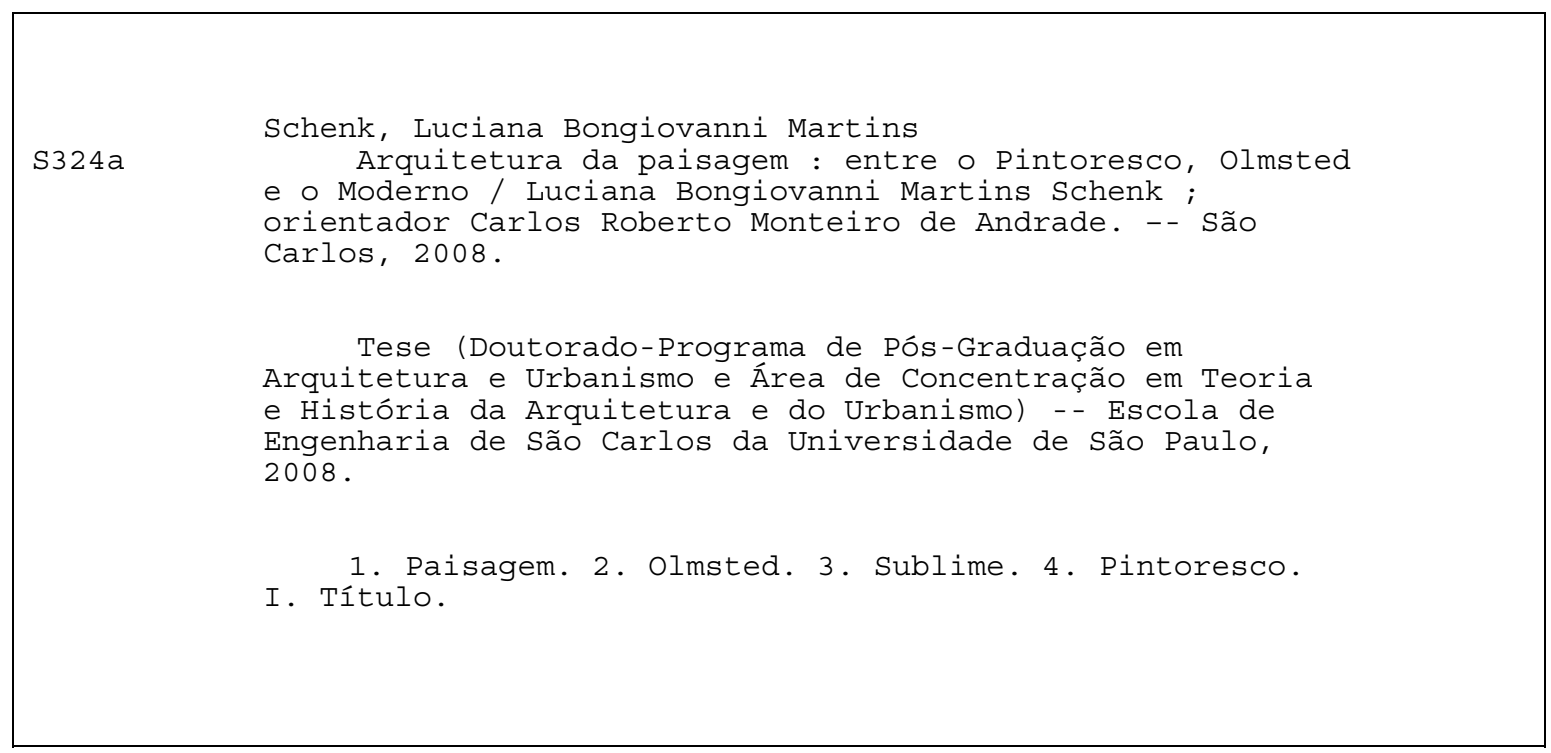


FOLHA DE JULGAMENTO

Candidata: Arquiteta LUCIANA BONGIOVANNI MARTINS SCHENK

Tese defendida e julgada em 27/08/2008 perante a Comissão Julgadora:

Cales de theles.

aprovada

Prof. Dr. CARLOS ROBERTO MONTEIRO DE ANDRADE (Orientador)

(Escola de Engenharia de São Carlos/USP)

Whiniva Movtalin

Prof. Dr. VLADIMIR BARTALINI

(Faculdade de Arquitetura e Urbanismo/USP)

aprovade

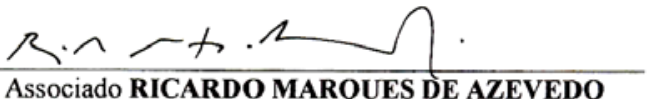

aprovada.

Prof. Associado RICARDO MARQUES DE AZEVEDO

(Faculdade de Arquitetura e Urbanismo/USP)

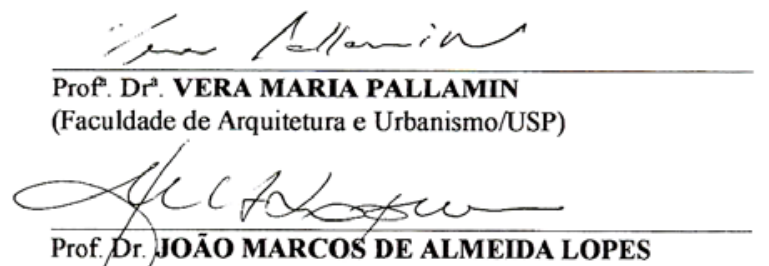

AnNoutin

(Escolade Engenharia de São Carlos/USP)

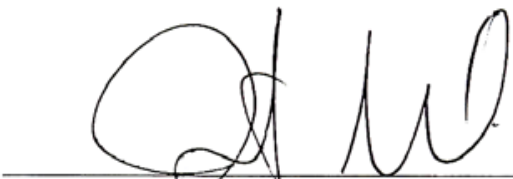

Prof. Titular RENATO LUIZ SOBRAL ANELLI

Coordenador do Programa de Pós-Graduação em Arquitetura e Urbanismo

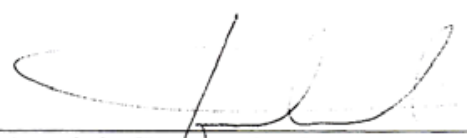

Prof. Associado GERALDO ROBERTO MARTINS DA COSTA Presidente dáComissão da Pós-Graduação da EESC 

Ao professor orientador, Carlos Roberto Monteiro de Andrade, Mancha, por sua seriedade, interesse e refinada interlocução.

Ao Departamento de Arquitetura e Urbanismo da EESC-USP, pelo apoio para a realização desse trabalho; em particular aos professores Carlos Alberto Ferreira Martins, João Marcos de Almeida Lopes, Rui Sardinha Lopes e Cibele Saliba Rizek, pelo empréstimo de preciosos livros e aulas memoráveis; e aos funcionários, Antônio João Tessarin, Sérgio Carlos Celesti, Fátima Maria do Norte Lourenço Leal Mininel, Paulo Ceneviva, Lucinda de Brito Torres, Alessandro Maurício de Souza e Willian Thomazo Vaz, pela gentileza e apoio sempre presentes.

Aos funcionários da Biblioteca Central da EESC-USP pela dedicação e profissionalismo.

Pelo trabalho de diagramação preciso e inspirado, sou grata a Daniela Zavisas Hladkyi e Daniel Morais Paschoalin, e pela preparação das imagens realizada por José Fernando Treviso Filho e Mailton Sevilha.

À amiga e designer Lorenza Pavesi pela interlocução e auxílio bibliográfico.

Ao primo Evaristo Pereira Goulart pelas traduções cuidadosas e pelo apoio amigo.

Um especial agradecimento a Leandro e Lia Schenk, pelo afeto fundamental. 



\section{Arquitetura da Paisagem entre o Pinturesco, Olmsted e o Moderno}

resumo:

Esse trabalho pretende investigar as diferentes percepções de significado da palavra paisagem e seus desdobramentos na atividade do arquiteto urbanista.

Para tanto, percorre um primeiro desenvolvimento que associa paisagem às diferentes concepções que se têm dela, procurando distinguir a qualidade que nos parece fundamental: a de ser um grande articulador de temas, lugar de múltiplas valências estéticas que dão significado à relação entre homem e natureza.

A confusão entre paisagem e o que venha a ser natureza, associado ao fenômeno de supremacia de uma suposta ciência e conseqüente crescimento da figura do planejamento corroboram a redução do complexo significado da paisagem.

A questão da possível sobrevivência em tempos modernos de chaves estéticas ligadas ao século XVIII constitui o cenário para a distinção da figura de Frederick Law Olmsted como pioneiro da atividade da arquitetura da paisagem com dimensões para toda a cultura de uma época.

A paisagem como a construção de um olhar comparece nessa elaboração, tecendo a partir de exemplos históricos uma multiplicidade de significados que recusam os estreitamentos, apontando algumas fontes de possíveis enganos. A tese afirma a dimensão cultural e estética da arte como pivô nas criações de uma arquitetura da paisagem. 


\section{Landscape Architecture amid Picturesque, Olmsted and Modernity}

abstract:

This research intends to explore the several meaning perceptions of the word Landscape and their connection to the activity of the architect.

Therefore, it runs at first the different concepts of the term Landscape, trying to sort out of them the quality that seems fundamental to us: to be the great link to different themes, the place of multiple aesthetic values that makes meaningful the human-nature relationship.

The confusion between concepts of landscape and nature, due to the supremacy of so-called science, and the subsequent outgrowth of planning corroborate the reduction of the complex meaning of the landscape concept.

The question of a possible survival in modern times of aesthetic keys from the $18^{\text {th }}$ century constitutes the background to the distinction of Frederick Law OImsted as a pioneer in the activity of landscape architecture, of great significance of a whole era.

Landscape as a construction of the eye appears in this elaboration, interlacing from historical examples a multiplicity of meanings that rejects to be straitened, and points to sources of possible misunderstandings.

This work reaffirms the cultural and aesthetic dimension of art as motor for the inventions of landscape architecture. 
91 pequena introdução

92 anos de formação

97 caminhando e refletindo sobre a Inglaterra

100 um período no sul do país e a configuração de uma nova atividade

102 uma atividade sob medida

104 a premiação

109 a guerra civil e sua participação

111 a experiência em Mariposa Estate

114 o retorno ao parque e os anos de produção da Olmsted, Vaux \& Company

116 congruências, o princípio orgânico e o amadurecimento de um processo reflexivo

118 sistema de parques I - Brooklyn

121 sistema de parques II - Boston

126 Riverside

129 a contribuição na distinção de uma atividade profissional

\section{CAPÍTULO V - CONCLUSÕES}

138 primeira parte

141 segunda parte

150 parte final

156 BIBLIOGRAFIA

161 IMAGENS 
A proposta de doutorado teve como intenção original investigar o papel da arte na produção de projetos da paisagem contemporâneos. Partia-se da hipótese de que a arte pudesse operar como um pivô na elaboração desses projetos. A idéia nascia da experiência didática e profissional e se fundamentava em hiatos: a distância entre discursos e representações, entre discursos e obra construída, constatados desde nossa dissertação de Mestrado ${ }^{1}$. Acreditávamos ser a arte caminho, uma possível ponte entre essas instâncias.

O desenvolvimento da pesquisa trouxe à luz o fato de que essa percepção provavelmente nascia do envolvimento com um especial campo disciplinar ligado à paisagem e denominado Paisagismo na maior parte dos cursos de Arquitetura e Urbanismo do Brasil. Para o Paisagismo, o contato com a realidade do lugar, com sua natureza física e forma de ocupação são sempre questões relevantes. O Paisagismo, cujas estratégias de projeto incluíam intensivo relacionamento de informações de diferentes naturezas, parecia mais refratário às abstrações 2 que as outras disciplinas de projeto.

Desde o princípio nos interessava investigar como o processo de desenho, o comumente conhecido design process dos praticantes da área acontecia; se seria possível de algum modo auxiliar ou estimular sua experimentação tendo a arte como horizonte: ele seria o meio através do qual a idéia se transformava, o meio pelo qual potencialmente a questão da arte poderia se tornar manifesta.

Até o exame de qualificação investigou-se a origem do campo disciplinar nos Estados Unidos e Brasil, especialmente Rio de Janeiro e São Paulo, ao mesmo tempo em que se procurou levantar as referências bibliográficas e historiográficas disponíveis a esses profissionais e estudantes. Esse processo, associado ao

\footnotetext{
1 Elevado Costa e Silva: processo de mudança de um lugar. Programa de Pós Graduação Faculdade de Arquitetura e Urbanismo - Universidade de São Paulo, 1997.

2 "A ciência manipula as coisas e renuncia habitá-las. Estabelece modelos internos delas e, operando sobre esses índices ou variáveis as transformações permitidas por sua definição, só de longe em longe se confronta com o mundo real. Ela é, sempre foi, esse pensamento admiravelmente engenhoso, desenvolto, esse parti pris de tratar todo ser como 'objeto em geral', isto é, ao mesmo tempo como se ele nada fosse para nós e estivesse no entanto predestinado aos nossos artifícios”. MERLEAU-PONTY, Maurice. O Olho e o Espírito / seguido de A linguagem indireta e as vozes do silêncio e A dúvida de Cézanne. São Paulo : Cosac \& Naify, 2004, p13.
} 
percurso elaborado nos trabalhos programados, foram fundamentais para a determinação do que agora se apresenta.

A partir de ambos os trabalhos programados, Moderno e Paisagem e o Sublime e a Paisagem, recortaram-se com maior nitidez questões que conformam não só o próprio campo disciplinar do Paisagismo desde sua origem, mas especialmente a questão da cultura como construtora do significado de uma paisagem.

A historiografia revelou a figura de Frederick Law Olmsted como um dos pioneiros da atividade profissional e um dos seus maiores defensores acerca de suas específicas qualidades relacionadas à arte. De modo que nossa hipótese primeira se reapresentava: a arte como pivô de um desenvolvimento em projeto; entretanto, seria necessário esclarecer a qualidade da arte que se tinha em mente nesse período inaugural para relacioná-la ao tempo presente. A arquitetura dessas passagens, como configurar esses nexos entre as informações que havíamos reunido tornou-se o desafio desse trabalho.

A questão se deslocava dos objetos para as condições de possibilidade dos objetos ${ }^{3}$. Atenta à pluralidade das histórias, a pesquisa não pretendeu apenas uma incursão à vida e projetos de Olmsted, que ao utilizar o termo landscape architecture, [arquitetura da paisagem], buscou distingui-la também como um campo de saberes ligado à arquitetura; ao reconstruir essa história procurou-se sobretudo perceber qual seria o universo de autores e experiências que poderiam ter participado de suas afirmações, crenças e defesas. Quando essas questões são investigadas, toda uma genealogia que não diz respeito apenas a Olmsted surge, e é elaborada nos três primeiros capítulos com a clara intenção de sustentar a idéia do contato entre chaves estéticas do século XVIII e o Moderno.

O primeiro capítulo Paisagem procura abordar alguns lados envolvidos em sua possível definição. Desse movimento emergem duas constatações fundamentais: a paisagem é fruto de uma construção cultural e histórica, e a paisagem não é natureza, da qual nasce o segundo capítulo.

\footnotetext{
3 HANSEN, João A. A temporalidade na cultura contemporânea. In Conversas no Ateliê, palestras sobre Artes e Humanidades. Direção Vera M. Pallamin, coordenação Joaci Furtado. São Paulo : FAU - USP, 2002.
} 
O capitulo intitulado Natureza apresenta sua origem na primeira definição ocidental conhecida, a grega, até o século XVIII, para então nos determos com maior atenção nesse período - nele pareciam estar dispostas chaves estéticas que compareciam, ainda que sob traduções, num suposto contato com o Moderno.

O terceiro capítulo investiga tais chaves, pinturesco e sublime, como pontos distintivos no que diz respeito à construção de uma paisagem. Essa elaboração, que atribui sentido à relação entre homem e natureza, interessa substancialmente porque antecipa e mesmo revela questões importantes relacionadas à experiência e à percepção estética.

A conclusão se faz em três partes. a primeira busca apresentar a questão do Moderno - que havia sido trabalhada no último trecho do primeiro capítulo, paisagem - , em relação a esse precursor da reflexão sobre o planejamento das cidades que foi Olmsted. Na segunda parte trazemos à tona a ainda presente pouca visibilidade da atividade profissional e do campo disciplinar, ela parece ligar-se ao modo como desenvolvemos os projetos, bem como à qualidade das reflexões teóricas e posturas relacionadas às investigações estéticas realizadas no tempo presente.

A intenção foi revelar parte dessa potencial especificidade, tornando mais nítida nossa participação dentro da atividade de arquitetura e urbanismo. Como veremos no decorrer do desenvolvimento não são poucas as questões implicadas na construção da paisagem; a confusão dela com natureza, que também aparece reduzida nessa ordem de razões, leva à compreensão do paisagista como aquele que realiza projetos verdejados. Desse modo, e a partir de sua própria história, da qual, a que escrevemos participa e não pretende ser a única, esse trabalho busca ainda explicitar as qualidades de sua dimensão artística e técnica, argumentando acerca da denominação que acreditamos, melhor a define: Arquitetura da Paisagem. 


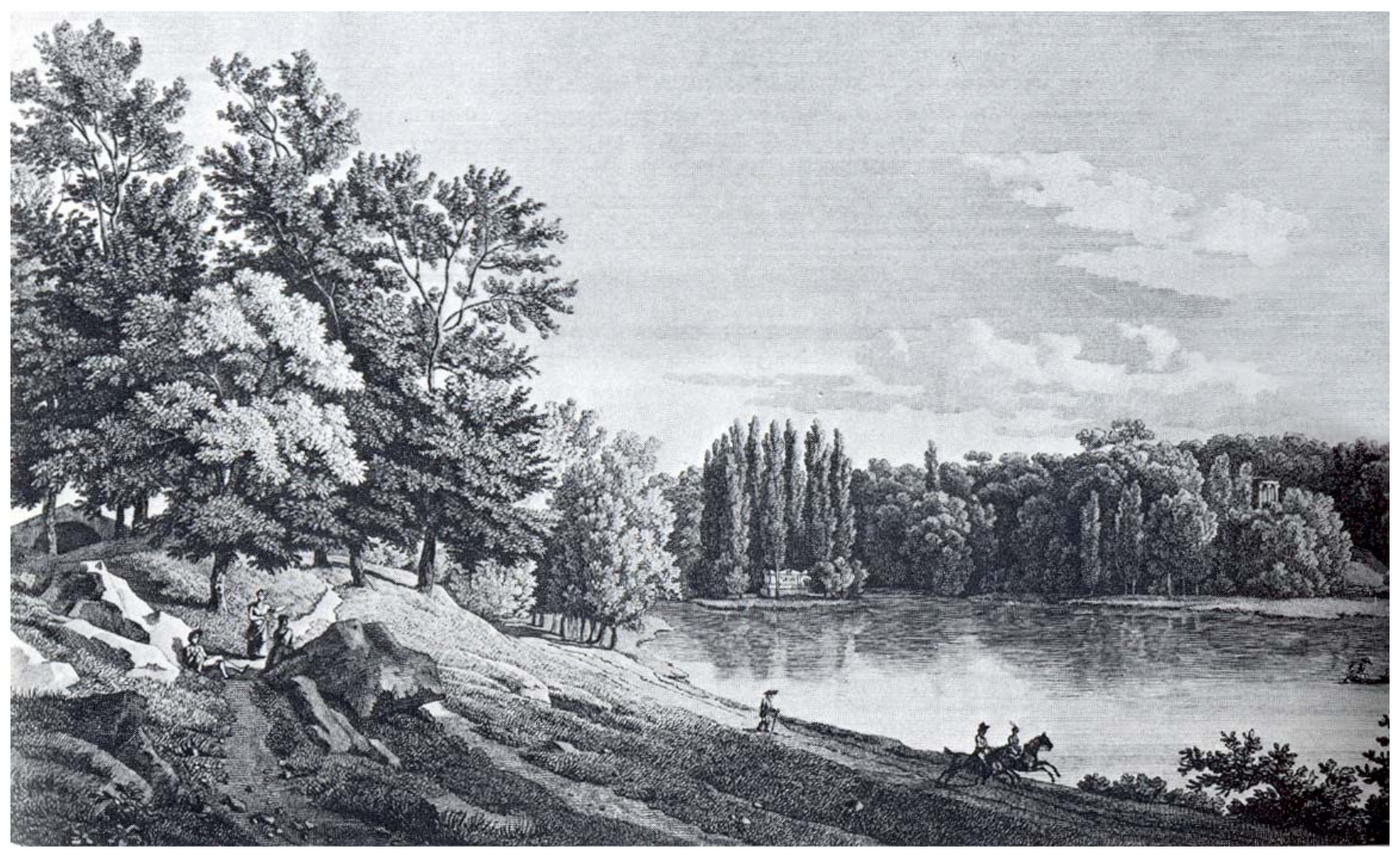

PAISAGEM

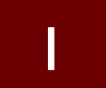


Alexander von Humboldt, cuja obra mestra Cosmos ${ }^{1}$, 1845, Ihe confere forte participação na fundação da Geografia como campo de conhecimento, concede à pintura um status privilegiado como meio de contemplação da fisionomia da natureza. Embora o naturalista prussiano defendesse o mérito da experiência sobre a representação, percebia na arte de pintar paisagens e apresentá-las ao observador remoto, um meio de fazê-lo participar desse momento único de comunhão e totalidade; ele recomendava aos pintores que, evitando as estufas ou obras de botânica, trabalhassem nos sítios de onde extraiam suas paisagens, de modo que pudessem entrar em comunicação com a natureza e, graças a isso, obter uma representação que possuísse a emoção dos lugares mesmo 2.

As ilustrações dos livros, fruto de suas expedições, mostram uma noção de paisagem que transparece nas imagens: do lado direito se representa com técnicas de figuração da época, o esquerdo em detalhes e inscrições nomeando cada planta e analisando sua fitogeografia. Humboldt é crítico do modo de descrever francês calcado apenas numa representação eminentemente técnica e opta pelas diversas formas iconográficas, explicativas, ou mesmo evocativas que podem oscilar entre a poesia, a perspectiva pictórica e a descrição literária 3 , seu horizonte é aquele que pretende educar e informar para além do conhecimento objetivo, visando a formação humanística.

A geografia passa no decorrer desses séculos pelo embate da construção de sua epistemologia, e o tema da paisagem ocupa nesse desenvolvimento diferentes lugares. No século XX, Milton Santos, no segundo capítulo do livro intitulado A Natureza do Espaço, apresenta seu percurso intelectual e a tentativa de definição de espaço

\footnotetext{
1 Kosmos, A Geral Survey of Physical Phenomena of the Universe. London : Hippolyte Bailliere, 1848 . Humboldt viaja entre 1799 e 1804 pela América do Sul em companhia do botânico Aimé Bonplant. Entre 1814 e 1825 os trinta volumes da expedição são publicados em França; na Inglaterra a tradução aparece entre 1814 e 1829. Cf. MARTINS, Luciana de Lima. A Pintura inquieta da Paisagem Tropical, apud 10.Colóquio Internacional de História da Arte: Paisagem e Arte. Coordenação Heliana Angoti Salgueiro. São Paulo: CBHA/CNPq/FAPESP, $2000, \mathrm{p} 127$.

2 FERNÁNDEZ, BOLET e ESTEVA-GRILLET. Ideas de Humboldt sobre a Paisagem, apud SALGUEIRO, 2000 , pp 209 e 211.

3“Não existe nesse ponto uma só convenção, (...), as paisagens que mostra para educar tocam a sensibilidade estética e kantianamente, assim, através do prazer desinteressado educam na diversidade do mundo natural e humano", (p 101), in SILVESTRI, Graciela y ALIATA, Fernando. El Paisaje como Cifra de Armonía - relaciones entre cultura y naturaleza través de la mirada paisajística. Buenos Aires : Nueva Vision, $2001, \mathrm{p} 101$.
} 
como grande objeto de investigação da Geografia. Suas primeiras considerações, ainda na década de 70 , definiam o espaço como par: fixos e fluxos, duplo que amadureceria até a tese que acreditava, melhor expunha esse objeto fundamental: “... cabe estudar o conjunto indissociável de objetos e sistemas de ações que formam o espaço". Seu esforço era, segundo seu depoimento, auxiliar na construção do campo disciplinar, evitando a utilização de conceitos migrados de outras áreas, carregados de outros percursos e estranhos à questão investigada. Ele se apercebera de que o debate filosófico, bem como interdisciplinar, aconteceria apenas a partir dessa construção, daí a importância de precisar termos e afinar idéias. A paisagem, segundo sua conceituação, é um conjunto de formas que num dado momento exprimem as heranças e representam as sucessivas relações localizadas entre homem e natureza. Essas formas somadas à vida que as anima seria o espaço.

A paisagem é afirmada, então, como construção transversal, uma imagem de diferentes tempos que une objetos presentes e passados; um sistema material que existe através da coexistência de suas formas, expressando diferentes momentos históricos ${ }^{4}$. Aqui, a definição de paisagem carrega uma fixidez que só ganha movimento a partir da idéia de espaço, esse sim, articula as ações humanas e cria as condições de existência, portanto de realidade filosófica.

0 contemporâneo e também geógrafo Aziz Ab'Sáber 5, compartilha a dimensão histórica e de herança que o termo paisagem guarda; entretanto, a matriz natural ganha contornos mais definidores. Essas particularidades denotam existir, num mesmo campo disciplinar, dissensões e ênfases quer seja sobre o objeto de estudo, quer seja sobre a qualidade desse objeto.

Digna de nota, uma vez que testemunha o contato com a perspectiva humboldtiana, é a fala de um expoente anterior da geografia, que manteve estreito contato com o território brasileiro, Pierre Monbeig. Em aula inaugural

\footnotetext{
4 SANTOS, Milton. A Natureza do Espaço. Técnica e Tempo. Razão e Emoção. São Paulo : Edusp, 2002, p. 103 e 104.

5 “Todos os que se iniciam no conhecimento das ciências da natureza - mais cedo ou mais tarde, por um caminho, ou por outro - atingem a idéia de que paisagem é sempre uma herança. Na verdade, ela é uma herança em todo sentido da palavra: herança dos processos fisiogeográficos e biológicos, e patrimônio coletivo dos povos que historicamente as herdaram como território de atuação de suas comunidades". AB'SÁBER, Aziz. Os Domínios de Natureza no Brasil; Potencialidades Paisagísticas. São Paulo : Ateliê Editorial, 2003, p. 9.
} 
para o curso em 1935, Monbeig 6 , que seria um dos responsáveis pela formatação do curso de Geografia no Brasil, afirmaria ser o campo de estudo do geógrafo a paisagem e, para compreendê-la, seriam necessárias incursões nas demais ciências afins. Em seus Ensaios de Geografia Humana Brasileira 7 estabelece o ponto de partida do método geográfico: abrir os olhos para as paisagens, ir além da mera descrição e perceber para além das linhas e cores o significado profundo e o valor humano da paisagem; nesses escritos o autor questiona inclusive a existência de uma paisagem natural: o mote mesmo da paisagem implica na ação humana 8.

O termo paisagem participa de diversas áreas do conhecimento; uma gama de profissionais, especialidades, ou simplesmente interesses operam sobre essa temática, recortando, de acordo com sua formação, uma especial perspectiva, de sorte que se parte da hipótese que a paisagem do geógrafo, ecólogo, biólogo, literato ou arquiteto-urbanista relaciona-se a distintas percepções. Interessa aqui reter que essa percepção diferenciada redunda em distintas qualidades reflexões e prioridades, experiências e propostas, o que gera um grande desafio no estabelecimento de uma epistemologia relacionada à questão da Paisagem. Contudo, algo parece comparecer em todas elas: a compreensão da paisagem como algo que se relaciona à história, à soma dos tempos que conforma os lugares, o que implica numa construção cultural e num modo de perceber essa relação.

\section{a paisagem como método/meio/caminho/significado}

O fenômeno de transposição contemporâneo da complexa noção de paisagem em equivalente a conceitos como os de meio-ambiente, território, ou mesmo espaço, observável em muitos dos campos do conhecimento que

\footnotetext{
6 "Para o discípulo da escola francesa, a geografia era uma descrição explicativa sendo essencial reter que a paisagem era o campo de estudos do geógrafo (...) diante da paisagem , a experiência sensivel da observação deveria associar-se às ciências vizinhas, ou afins da geografia humana: a geologia, a botânica, a sociologia a etnografia, a economia, política e outras, delas escolhendo o que Ihe parecesse mais útil para fazer a síntese geográfica". SALGUEIRO, Heliana A. Pierre Monbeig e a Geografia Humana Brasileira; a dinâmica da transformação. Bauru : Edusc, 2006, p 94.

7 MONBEIG, Pierre. Ensaios de Geografia Humana Brasileira. Rio de Janeiro : Livraria Martins, 1940.

8 SALGUEIRO, Heliana A. Pierre Monbeig: A Paisagem na Óptica Geográfica, apud SALGUEIRO, 2000, p 165.
} 
tratam do assunto, denota um desvio da dimensão original da idéia de paisagem e uma redução de suas qualidades formativas.

A proposta apresentada pelo livro de Silvestri e Aliata, El Paisaje como Cifra de Armonía (2001), que investiga as alternativas do habitar humano que a sensibilidade paisagística ilumina nos parece fundamental para recuperar, e fazer soar uma vez mais, a dimensão da paisagem, percebendo-a como o grande elemento articulador de temas que aparentemente transcorrem em separado 9.

O esvaziamento da noção de paisagem e sua equivalência a conceitos oriundos do campo das ciências chamadas aplicadas em especial revelam um hiato maior: a paisagem e suas valências estéticas tecem, através da perspectiva histórica, a brecha entre o homem e o mundo. Ela é um poderoso meio que auxilia na criação do nexo e sentido de nossa existência.

A paisagem não é natureza ${ }^{10}$. Gombrich afirmaria ser necessário um ponto de vista e a fala de um espectador que experimenta e dá sentido à experiência; é fundamental segundo essa reflexão, a separação entre homem e mundo produzida pela existência de uma linguagem.

Entretanto, é a própria natureza estética dessa experiência, paisagem, que estabelece uma especial dimensão para essa sutura; mais que total separação, em tempos posteriores ao advento da fenomenologia em que sujeito e objeto não constituem mais um par, trata-se antes de uma ambígua forma de relação, na qual o que se olha se reconstrói a partir de recordações, perdas, nostalgias próprias e alheias, que remetem às vezes a grandes períodos da sensibilidade humana, outros a modas efêmeras 11.

Anne Cauquelin ${ }^{12}$, em sua investigação sobre a origem da confusão entre natureza e paisagem, afirma que esse equívoco é fruto de um aprendizado de séculos: a arte nos ensina a olhar a natureza; essa hipótese que

9 SILVESTRI y ALIATA, op cit, 2001, p 10 e 11.

10 GOMBRICH, Ernst. "Nature and Art as Needs of the Mind”, (1981) in The Essential Gombrich - Selected Writings on Art and Culture, edited by Richard Woodfield. London : Phaidon Press, 1996, p 567.

11 SILVESTRI y ALIATA, op cit, 2001, p 11.

12 CAUQUELIN, Anne. A Invenção da Paisagem. São Paulo : Martins Fontes, 2007. 
transforma a natureza contemplada em paisagem, torna o olhar do paisagista um olhar estético, implicando numa conexão inseparável entre forma percebida e seu significado.

Parece residir nessa lógica, parte da resposta sobre o significado, bem como a origem da maior confusão sobre a paisagem.

paisagem e história: a construção de um olhar

Se nos voltarmos à origem do termo veremos que a distinção do léxico surge apenas no século XV 13, e acontece de modo correlato em diversas línguas a partir da palavra que designa terra, no sentido de território e país. Land / Landschaft, em alemão; land / landscape, em inglês; Pays / Paysage, em francês; Paese / Paesaggio, em italiano; País / Paisagem, em português - essa estreita ligação descortina uma noção histórica do termo paisagem presente em sua raiz. A configuração de um território e suas qualidades, o desenvolvimento da noção de pertencimento a esse lugar e, finalmente, a associação dessas a um povo, com as implicações culturais que a questão representa são aspectos fundamentais dessa construção.

Segundo autores essa ligação descortina um complexo processo cultural. A argumentação de que a noção de paisagem nasce em primeiro lugar no olhar que se modela pela percepção, e que se amplia a partir desse contato com as artes em geral e com a pintura em particular, é defendida por Alain Roger que explora a hipótese culturalista no estabelecimento das idéias de beleza e paisagem. 0 autor retoma um termo inaugurado por Montaigne no século XVI e traduzido aqui por artealização, cujo significado seria a afirmação de que nossa experiência é fruto de uma percepção gerada a partir de modelos artísticos, são aquisições, ou melhor, invenções culturais que podemos datar e analisar ${ }^{14}$.

13 ROGER, Alain. La Naissance du Paysage em Occident. Apud SALGUEIRO, 2000, p 34.

14“Existem dois modos de artealizar um terreno para transformá-lo em paisagem. A primeira consiste em inscrever diretamente o código artístico na materialidade do local, sobre o terreno, a base natural. Artealiza-se in situ. É a arte milenar dos jardins, o landscape gardening a partir do século XVIII, e, mais próxima de nós, a Land art. A outra maneira é indireta. Não se artealiza mais in situ, mas in visu, opera-se sobre o olhar coletivo, fornece-se lhe modelos de visão, esquemas de percepção e de fruição." ROGER, apud SALGUEIRO, op cit, p 33. 
Contudo, persiste a questão, a partir de quando se pode falar em paisagem? A história da paisagem reconhece diversos inícios. Certos livros remontam essa história às primeiras manifestações da cultura humana ${ }^{15}$, mas há momentos em que a paisagem como fenômeno aparece com maior nitidez. A Grécia Clássica e o chamado Século de Ouro Romano coincidem com o primeiro assinalar do que constituiu uma paisagem, especialmente sob a forma de jardim, para autores como Pierre Grimal ${ }^{16}$. Uma segunda emergência colocar-se-ia em relação à historicamente conhecida Idade Moderna, mas que se informa e reinventa esse passado clássico a partir da grande fonte que é a palavra escrita, participando ativamente desse modelar da percepção e formação de um olhar.

Augustin Berque 17 enunciaria as condições de existência da paisagem enquanto expressão cultural em uma sociedade: em primeiro lugar há que existir a representação lingüística, o termo; em segundo a representação literária, oral, ou escrita, nas quais se descrevem as belezas da paisagem; o terceiro ponto diz respeito às representações pictóricas sobre o tema e, enfim, as representações concretas dos jardins.

Embora seja possível pensar numa paisagem, uma vez que se encontra em Vitrúvio, em sua De Architectura, o neologismo: topia, forjado a partir do grego topos (país), e que designaria o que hoje denominamos paisagens, ou ainda a presença, na Historia Natural de Plínio ${ }^{18}$, o Velho, da expressão "topiaria opera", (obras topiárias, paisagísticas), para designar os frescos murais que, nas vilas imperiais, representam as paisagens, urbanas ou rurais. $O$ conjunto de condições seria satisfeito para Berque em relação à Europa Ocidental apenas em finais do século XV, de maneira que a partir de então, segundo a hipótese apresentada, nossa experiência em relação à paisagem passa a ser guiada por esses modelos artísticos e seus desdobramentos.

\footnotetext{
15 JELLICOE, Geoffrey \& Susan. The Landscape of Man. London : Thames and Hudson, 1995.

16 GRIMAL, Pierre. Les Jardins Romains. Paris : Presses Universitaires de France, 1967, (1943).

17 BERQUE, Augustin. Les Raisons du Paysage, in ROGER, 2000, p 34.

18 Gaius Plinius Secundus nasce ao norte da Itália, Transpadane Gaul em 23, ou 24 aC. durante o principado de Tibério. Sua extensa obra inclui os 37 livros da História Natural cujo principal objetivo seria "explicar o universo e seus fenômenos em termos racionais de modo a libertar as mentes dos homens do medo através da grande compreensão do mundo". PLINY, THE ELDER, Natural History, a selection. London : Penguin Books, 1991, Introduction, p xvii.
} 
Até o chamado Renascimento a pintura não ocupara posição de destaque nas artes da representação; a descrição ou criação poética, o léxico era a forma de representação dominante. 0 que merece atenção é o papel desempenhado por esse poderoso meio que nos vem supostamente pela visão e que toma o existente: não é a pintura que informa a arte dos jardins, mas ambas são informadas pela mesma produção, pelo mesmo modo, a perspectiva. De sorte que a outra chave que se manifesta na construção da noção de paisagem diz respeito à sua configuração enquanto desenho, representação; Anne Cauquelin credita a construção do equívoco que torna equivalentes natureza e paisagem a essa dupla: a palavra e a representação.

A paisagem grega não se oferece à visão, mas ressoa no ouvido, na luz da inteligência. A Natureza fora tratada fundamentalmente pela palavra na cultura clássica, e a metáfora seria a grande instrumento de criação de seu significado; a metáfora, figura de linguagem que implica numa transposição, termina por gerar uma folga nesse significado, uma licença que engendra a possibilidade de equivalência entre os termos natureza e paisagem em tempos posteriores.

A literatura seria a pioneira na invenção da paisagem: a Ítaca descrita por Palas-Atena a um Ulisses cego, ou a existência da palavra grega kepos-hortus e sua descrição como lugar de descanso e meditação, ou ainda, a desconhecida forma pela qual se mostraria ao mundo os Jardins de Epicuro, restando apenas a metáfora de um lugar para ensinamentos; a imagem desses lugares foi recriada pelas épocas a partir dos modelos artísticos então disponíveis ${ }^{19}$.

A força da representação perspectivista se torna realidade graças às novas estruturas de percepção por ela inauguradas; essa hipótese de autonomia informa nosso modo de perceber bem como as construções mentais: a visão que mantemos da natureza, a idéia que fazemos das distâncias, das proporções, da simetria. Essa

\footnotetext{
19 Evitando anunciar a gênese desse processo de invenção da paisagem como conjunto estruturado a partir de um corpo de doutrina e os meios de realizá-la, a perspectiva, a autora opta, estrategicamente, pela arbitrariedade da origem:“Autores confiáveis situam seu nascimento por volta de 1415. A paisagem (termo e noção) nos viria da Holanda, transitaria pela Itália, se instalaria definitivamente em nossos espíritos com a longa elaboração das leis da perspectiva e triunfaria de todo obstáculo, (...) a paisagem adquiria a consistência de realidade completamente autônoma, ao passo que de início, era apenas uma parte, um ornamento da pintura." CAUQUELIN, op cit, pp 35 a 37 .
} 
técnica enquanto síntese e seu papel na estrutura de intelecção do mundo tornam possível a equivalência entre artifício e natureza: Tocar a paisagem, modelá-la ou destruí-la, é tocar a própria natureza 20.

Essa implicação, em curso ainda nos atuais tempos, põe em xeque e distorce a principal qualidade original da paisagem, a saber: um meio, passagem para pensar e estabelecer relações entre artifício e natureza, entre homem e mundo.

\section{paisagem, história e arquitetura}

Não é possível fundar rigorosamente uma origem para a atividade do projeto do jardim 21; contudo, se pensarmos num período quando a autoria desses lugares passa a ser explicitada teremos uma suposta origem, ainda que uma vez mais arbitrária, junto ao século XV 22.

A noção de paisagem participa ativamente da constituição desses lugares, é no jardim humanista plenamente estabelecido no século XVI que se desenrola uma singular relação entre artifício e natureza; não se trata apenas do local do ócio e do prazer, mas também o lugar onde o pensamento acontece: alegorias, símbolos e jogos de significados fazem falar esse fragmento do mundo ${ }^{23}$. Trata-se ainda de uma parcela do território que se transforma com o objetivo de fruição não apenas do jardim em si, mas de uma totalidade, a cidade aqui participa como cenário do jardim, compondo-Ihe a paisagem.

\footnotetext{
20 CAUQUELIN, op cit, p 38 e 39.

21 Autores como o mencionado Pierre Grimal discordam dessa origem ligada à possibilidade de distinguir seus autores, na pesquisa histórica e arqueológica, desde que seja possível inferir a existência de um lugar que tenha sido objeto de projeto, aí se têm um início. O próprio conceito de paisagem é para esses autores, correlato ao momento em que romanos, sob a informação da cultura helênica e sua poesia, escritos e representação, concebem seus jardins não mais como simples plantio de árvores, mas uma profusão de espécies, tanques, estatuária e modelagem do relevo: “a grande novidade consistia na composição de paisagens". Cf GRIMAL, L'Art des Jardins. Paris : Presses Universitaires de France, 1974, p 24.

22 Sob a égide dos escritos clássicos, como os de Plínio,o jovem (século I aC) em meados do século XV, é realizada a Villa Médici nos arredores de Florença, por Miquelozzo para Cosimo de Medici. Nesse mesmo lugar Alberti, responsável por boa parte dessa leitura dos clássicos, a partir de 1468, conviverá com humanistas como Marsilio Ficino. Por sua vez, Bramante projeta no Vaticano o Jardim Belvedere em 1503, esse se constitui num primeiro período do chamado jardim Italiano. Cf. LAURIE, Michael. Intruducción a la architectura del paisaje. Barcelona : Gustavo Gili, 1983, (1975).

${ }^{23}$ Cf. CLIFFORD, Derek . A History of Garden Design. London : Faber \& Faber, 1962, Capítulo I Pliny and the Renaissance Garden.
} 
O resgate do Clássico no Renascimento através da literatura acontece a partir da leitura e tradução de textos nos quais as paisagens são o cenário onde transcorre a ação proposta por escritores do primeiro século antes de Cristo: Virgílio, Horácio e Ovídio. A questão, uma vez mais, é a da percepção e do sentido uma vez que a base que fundamenta toda a comunicação é o cânone da retórica.

Embora se tratasse de um jardim marcadamente arquitetônico, há o contraponto entre o bosque que participa da composição e as formas rigorosamente geométricas das construções. 0 modelo de beleza está ancorado no equilíbrio, e a simetria é sua razão de ordenamento24: os atributos da graça e amenidade são conquistados através de uma variedade controlada.

A existência desse jardim era garantida pela retórica graças à sua capacidade de mediação; suas figuras de linguagem ampliavam e desdobravam o estatuto de significação do representado criando um mundo no qual se inscrevia a paisagem. A compreensão dessa linguagem, a leitura dessas disposições era fundamental: um skéma sem morphé permaneceria vazio ${ }^{25}$, asseverava Leon Battista Alberti, pensador, escritor e arquiteto do Quatroccento: o mero desenho sem a forma que Ihe atribuía significado restava emudecido.

A historiografia da paisagem costuma iniciar seu percurso pela História do Jardim, articulando lugar e contexto, civilização e cultura. Se no século XVI o foco está na futura Itália, o século XVII corresponderia ao modelo chamado jardim formal francês e estaria relacionado ao domínio político, cultural e econômico de França durante esse período. Uma das faces desse domínio se encontra na paisagem; o território francês não oferecia a mesma qualidade de relevo acidentado presente na vizinhança de Florença ou Roma; os limites naturais menos presentes são cenário para o jardim se tornar a expressão de um grande poder precocemente concentrado nas mãos do soberano.

24 A simetria por sua vez, tivera naqueles dias uma compreensão para além de seu estreitamento enquanto eixo, significando objetos mensuráveis pelo mesmo padrão, redutíveis a uma unidade, a um número; a simetria era, para Vitrúvio, proporção, concordância entre o todo e as partes. SILVESTRI y ALIATA, op cit, pp 45 e 46.

25 LE DANTEC, Denise and Jean Pierre. Reading the French Garden: Story and History. Cambridge : MIT Press, 1990. 
O meio de composição operante se dá ainda através da retórica e pela leitura dos clássicos, porém um especial contato entre a França e o chamado Renascimento é proposto pelos autores Denise e Jean-Pierre Le Dantec; diz respeito tanto à própria definição de Renascimento, quanto à criação de paisagem como uma questão cultural e histórica: a origem do manuscrito Hypnerotomachia, ou Sonho de Poliphilo, editado pela primeira vez em 1499 na cidade de Veneza, e que passa quase despercebido nessa época. Trata-se de um escrito hermético ${ }^{26}$, neoplatônico e humanista, relacionado à busca primordial, e que se direciona para a redescoberta da beleza e virtudes clássicas. 0 que se apresenta é a chave de uma estética que reorienta a história do jardim letrado, escrito que os autores tributam ao próprio Alberti 27. A hipótese de autoria coteja a vinda de Alberti para Florença, sua convivência na casa dos Medici, o contato com Prospero e Francesco Colonna e as rusgas e perseguições papais ao Humanismo.

Independentemente do fato dessa hipótese ser verídica ou não, o que está em jogo aqui é o fenômeno não de Renascimento, mas de recriação de um antigo do qual participa a paisagem.

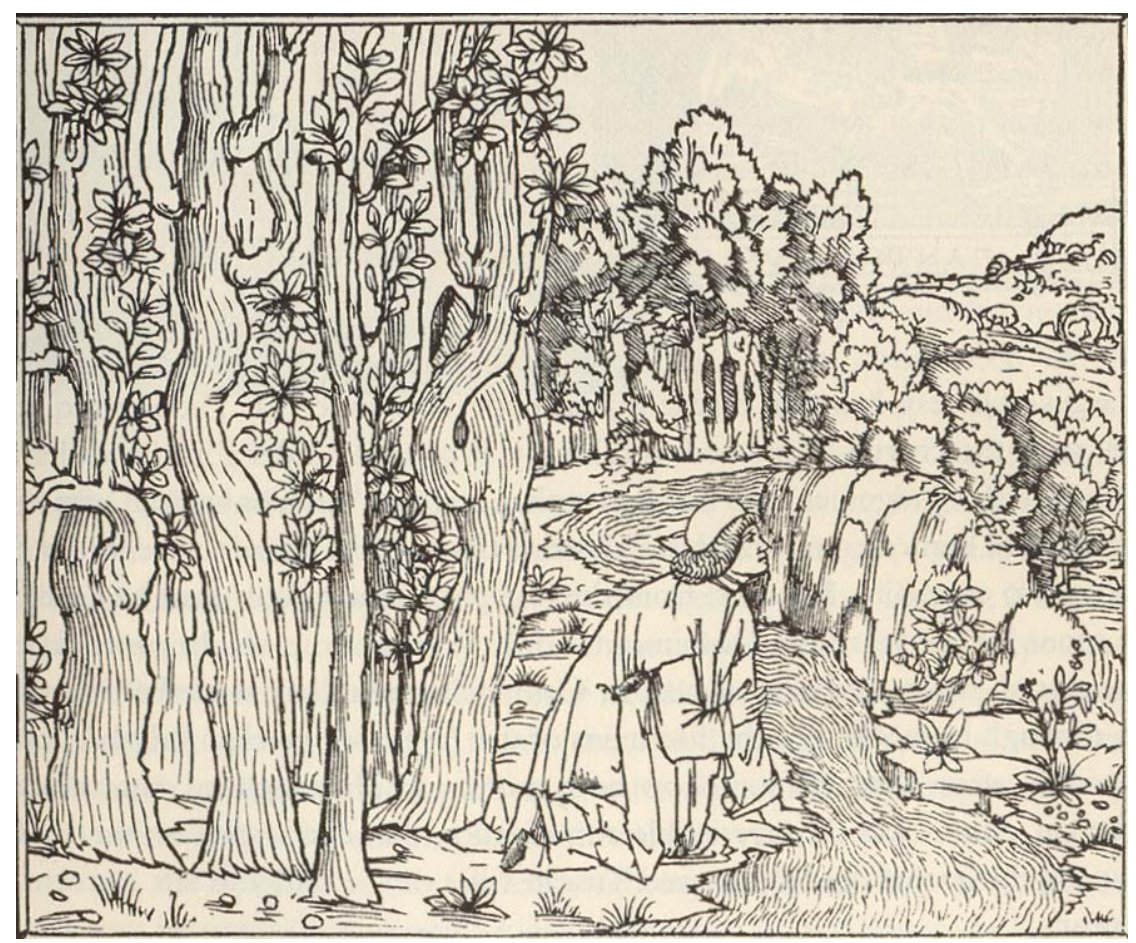

fig. 1 - Hypnerotomachia ou Sonho de Poliphilo

26 "O reconhecimento geral do macrocosmo e microcosmo relacionados à grande cadeia do Ser é a chave para a aceitação das correspondências que existem por toda a parte entre os mundos celestial e sublunar. No mundo antigo tais crenças parecem dar sólida base para a astrologia. (...). Os textos Herméticos adicionam novo ingrediente a essa visão de mundo. Eles seriam a base para que o homem pudesse ser visto como um elo favorecido dessa grande cadeia". DEBUS, Allen G. Man and Nature in the Renaissance. Cambridge, NY : Cambridge University Press, 1990, (1978), p 12.

27 LE DANTEC, op cit, p 48. 
Os significados do jardim e da paisagem que se constroem nesses tempos ultrapassam sobremaneira a mera descrição desses espaços, é necessário possuir o domínio das chaves que apresentam um dos lugares mais elaborados do período 28 ; chaves que fazem falar as imagens e descortinam os elos que constituíam os saberes humanos, esse é o significado da costura elaborada pela paisagem.

O contato entre Renascimento e França dá-se pela mesma casa dos Medicis. Maria de Medici ordena a Jacques Boyceau de la Baraudière, nos princípios do século XVII, a criação de um jardim para Luxemburgo inspirado na Hypnerotomachia, mesmo livro que, agora com quase cem anos de idade, será utilizado pelo preceptor de Luis XIV, Cardeal Mazarin, para informar-lhe acerca da estética dos jardins e da paisagem.

A especial condição de Jacques Boyceau, aristocrata letrado, pela virtude de posição e cultura, conspira para a mudança de status dos praticantes da profissão relacionada aos jardins, que têm lugar de destaque na corte: a encomenda de Maria de Médici de um novo Boboli para Luxemburgo redunda na transformação de algo originalmente Italiano num lugar inteiramente francês, uma tradução na forma e no espírito. Jacques Boyceau de la Baraudière será publicado apenas após sua morte em 1638; seu Tratado de Jardinagem de acordo com as Razões da Arte e da Natureza constitui a maior referência teórica sobre o jardim francês na época e significa, grosso modo, a vitória da razão sobre a sensibilidade 29 . A formação de Le Nôtre, principal homem à frente dos projetos de Vaux-le-Vicomte e Versailles, dar-se-á sob os auspícios de Boyceau e sua defesa da razão como a pedra de toque para a compreensão das questões da natureza.

É em França que o domínio sobre o território a partir das tecnologias se estabelece de modo mais contundente, isso se alicerça em termos de educação; aqui a paisagem se articula uma vez mais à percepção e se modela através da qualidade de formação de seu corpo de profissionais: a representação científica e técnica do território têm um papel central nesta transformação na medida em que a burocracia formada nas escolas de

28“O jardim é esse lugar no qual acontece a compreensão do território em transformação e sua fruição como paisagem, laboratório de técnicas agronômicas, lugar de reunião do exótico e do estranho, jogo de significados, alegorias e símbolos; fragmentos do Paraíso na Terra não apenas porque se propõe utopias literárias, ou ilusões poéticas, mas sim por que se constrói e experimenta. In, SILVESTRI E ALIATA, op cit, p 41.

29 “Em primeiro lugar, o arranjo do jardim deverá proceder a partir de um controlado processo de reflexão, não de modo a obedecer a qualquer princípio a priori, mas porque os interesses envolvidos são de natureza filosófica. 0 trabalho deverá ser inteiramente comandado pela razão e a razão é a medida necessária para o conhecimento das leis que regem a natureza, de modo que a arte depende disso". LE DANTEC, op cit, p 89. 
alto nível tende a identificar a realidade com o plano, e consequentemente projetá-la de acordo com a simplificação da representação ${ }^{30}$.

Recebe atenção o especial momento em que o jardim vai perdendo suas qualidades formativas baseadas na retórica, ao mesmo tempo em que a paisagem vai ganhando status de significação através de outras chaves relacionadas ao desvio da regra. O jardim dito inglês, também chamado paisagístico, é a expressão desse momento no qual liberdade e natureza tornaram-se intercomunicáveis na paisagem da Inglaterra do século XVIII.

\section{paisagem e filosofia}

Metafísica e ciência ainda convivem no século XVII, porém, não se trata de convivência pacífica, sobretudo no século XVIII quando a mesma ciência se torna a grande instrumento de desencantamento do mundo; a ela pouco interessará o que está para além das coisas físicas: a alma, o espírito, o interior. O século XVII apresenta problemas relativos à existência e ao Ser que serão suprimidos por uma ontologia cientificista que estreita uma miríade de significados latentes em uma perspectiva externa, que desemboca no que Merleau-Ponty 31 chama pequeno racionalismo: em 1900, o Ser será explicado pela ciência, mas em meados do século XVIII o Ser não estava totalmente vergado ou achatado sob o plano do Ser exterior. Esse embate terá na paisagem um lugar privilegiado: Pinturesco e Sublime são territórios nos quais as regras de composição são desafiadas, e o tido como confuso adquire singular sentido.

Desde o Renascimento a troca se dera através de chaves determinadas, havia confiança no intercâmbio simbólico; a crise, ou desconfiança dessa unidade alicerçada em bases metafísicas gera alternativas de representação que anunciam questões relacionadas à modernidade. Na Inglaterra do século XVIII o tema da

\footnotetext{
30 SILVESTRI E ALIATA, op cit, p 76.
}

31 "O século XVII é esse momento privilegiado em que o conhecimento da natureza e a metafísica acreditaram encontrar um fundamento comum. Cria a ciência da natureza sem, contudo, tomar o objeto da ciência como cânone da ontologia. Acredita que uma filosofia sobrepasse a ciência, sem ser sua rival". MERLEAU-PONTY, Maurice. 'Em toda e em nenhuma parte'; in Textos Selecionados, coleção Os Pensadores. Org. Marilena Chauí. São Paulo: Abril Cultural, 1984. 
paisagem nesse momento de ruptura com a retórica normativa e novos estabelecimentos supõe uma nova articulação entre moral, beleza e verdade.

A questão de fundo é que a população inglesa desse período procurava recriar o que, talvez, nunca houvesse de fato sido objeto de experiência daquela sociedade. Historiadores diferem na porcentagem, Simon Schama revela que nos tempos de Guilherme, o conquistador, por volta do ano 1100, apenas 15\% do território ainda permanecia florestado ${ }^{32}$, enquanto Keith Thomas 33 afirmaria que 20\% do país tinha cobertura vegetal à época do Domesday Book; na verdade, antes mesmo da chegada dos romanos, a geografia histórica data a retirada da mata selvagem, de maneira que não existia muito de um exemplo original a ser seguido. No tempo dos Tudors e Stuarts, as matas continuariam a dar lugar às pastagens e ao cultivo, até que a situação em relação aos combustíveis para o aquecimento durante o inverno e a matéria prima para a construção de embarcações tornam o desmatamento uma questão relevante. A derrubada ilegal de matas já sofria penalidades desde o século XVII; o rei James em 1610 manifestara-se pela preservação das matas e temor do desperdício, mas a origem da preocupação seria estabelecida partir do ponto de vista econômico e não de preservação, predominando a percepção das matas como lócus do selvagem, da marginalidade, em resumo, do medo.

O mapa de Cambridge de autoria de John Hammond, 1593, mostra bosques e o plantio de espécies ornamentais. No início do período Moderno, o plantio inspirado pelo desejo da amenidade e beleza se torna mais comum, especialmente relacionado às cidades nas quais se estabelecem as Universidades e o contato com os chamados Antigos. A comunidade letrada da Inglaterra do século XVIII acreditar-se-ia herdeira dos Antigos e como tal, natural detentora do conhecimento clássico. Desenvolviam sua capacidade de projetar e fruir lugares, traduzindo e ambientando na paisagem Inglesa o que de fato era uma nova criação ${ }^{34}$.

32 SCHAMA, Simon.Landscape and Memory. New York : Vintage Books, 1995, p 142.

33 THOMAS, Keith. O Homem e o Mundo Natural - as mudanças de atitudes em relação às plantas e aos animais (1500 - 1800 ). São Paulo : Companhia das Letras, 1988, p 229.

34 "Raramente a terra que se trabalha é uma paisagem. O próprio conceito de paisagem implica separação e observação. (...) o observador consciente de sê-lo: o homem que não apenas contempla a terra, mas também tem consciência do que está fazendo, como uma experiência em si, e preparou modelos sociais e analogias tiradas de outros campos para apoiar e justificar a experiência: esta é a figura que precisamos 
A paisagem desse jardim adquiria valor político e boa parte da sociedade se viu envolvida nesse entusiasmo relacionado ao bosque e às árvores: sem a paisagem não haveria cenário para as ações que se esboçavam: não é possível compreender esse movimento e essa mudança de atitude em relação à Natureza se não passarmos ao cenário maior que susteve a ficção de continuidade progressiva com o mundo greco-romano, [que] sustentou a revolução de 1688, e se manteve como símbolo das liberdades civis, garantia do progresso material e social: liberdade e natureza tornavam-se intercomunicáveis e paisagem expressava essa síntese ${ }^{35} \mathrm{e}$, ao mesmo tempo, a oportunidade e o desejo de empreender o novo, a mistura, a surpresa, o espanto, distendiam a harmônica idéia anterior de Beleza.

Uma nova Arcádia se desenha, mas dialeticamente, o aparato retórico não resistirá ao que vêm acontecendo ao redor: o mundo como experiência, as descobertas, os contatos entre civilizações; o desenvolvimento científico, o grande motor de compreensão e construção da paisagem, convive com um olhar de desconfiança que mira os desastres naturais: a paisagem como expressão de harmonia natural sofria duro golpe.

"Em fins do século XVIII e por todo o século XIX, doutrinários das Artes se conformam com a evidência de que o verdadeiro, se o há, nem sempre corresponde ao bom, nem ao belo, e, assim, vislumbra-se as frinchas através das quais novas poéticas virão a se insinuar. E não tardará que se admita ao gênio que não siga a regra, que a desconsidere, pois é esta que àquele deve submeter" ${ }^{36}$.

Perceber o trânsito entre uma concepção mecânica, para uma concepção orgânica de mundo é fundamental para que se compreenda, tanto os caminhos das artes, quanto a centralidade que a noção de paisagem passa a ter a partir de meados do século XVIII. $O$ artista é aquele que passa a falar pelas coisas sem mediação, o olhar sem filtros do poeta inspirado, uma reação à descrição das ciências da exterioridade e redução à quantidade.

procurar: não é um tipo de natureza, mas um tipo de homem." WILLIAMS, Raymond. O Campo e a Cidade, na história e na literatura. São Paulo : Companhia das Letras, 1989, pp 167 e 168.

35 SILVESTRI e ALIATA,op cit, p 75.

36 AZEVEDO, Ricardo Marques. Antigos Modernos: Contribuição ao Estudo das Doutrinas Arquitetônicas, (séculos XVII e XVIII). Tese de Livre Docência apresentada ao Departamento de História da Arquitetura e Estética do Projeto. Faculdade de Arquitetura e Urbanismo, Universidade de São Paulo, revisão de abril de 2007, p 7. 
De modo que se configuram oposições que antes não tinham razão de ser: formal versus vital, mecânico versus orgânico, abstrato versos concreto ${ }^{37}$.

O labirinto Romântico tem como único fio condutor a vontade e o estado de ânimo do poeta. Na doutrina estética de Schelling, Deus aparece como alfa e ômega da totalidade das coisas, o alfa é a inconsciência, o ômega a pura consciência: o artista busca em si, adentrando as forças obscuras e inconscientes que o habitam e as saca para a luz mediante violenta e agonizante luta interior 38 . Essa luta encontra correlato na Natureza física; as erupções vulcânicas e a energia eletromagnética são interpretadas como pulsos de vida: a verdadeira obra de arte seria então análoga ao que admiramos e percebemos na natureza, especialmente como força produtiva, não a mera cópia. 0 poder a força que antes causavam medo, são agora associados ao espetáculo, esse momento único de extrema vitalidade.

A Naturphilosophie ${ }^{39}$, filosofia da natureza, mas que em finais do século XVIII pode ser compreendida como filosofia da vida, representava a intenção de constituir uma ciência sob novas bases, que contemplassem a totalidade das coisas. Foi idealizada especialmente por não filósofos; Schelling era médico, Goethe, poeta e naturalista; Novalis, poeta e engenheiro de minas; Humboldt, criador da Geografia moderna; Ritter, pioneiro da eletroquímica.

A perspectiva se desloca da compreensão baseada nas ciências físico-matemáticas e se localiza numa alternativa baseada no Cosmos, o universo das coisas e da vida enquanto unidade, não aceitando o hiato existente entre matéria e espírito característico do domínio llustrado 40. A continuidade atestada pela experiência leva a uma percepção do mundo dita orgânica: a apreensão procura levar a um novo estado harmônico, pautado em novo patamar que não o exclusivamente racional.

\footnotetext{
37 SILVESTRI e ALIATA,op cit, p 86.

38 BERLIN, Isaiah. Las Raíces del Romanticismo. Madrid: Taurus, 2000, p 135.

39 “No início do século XIX a Naturphilosophie alemã é referência básica para as interpretações totalizantes e intuitivas do universo, (...). Distingue-se da ciência positiva, clássica material, corpuscular e mecânica, instituída por Galileu e Newton, em que se priorizam o conhecimento físico matemático, a morfologia estrita e a objetividade sem a problematização do sujeito." SEGALA, Lygia. A natureza Virgem e a Paisagem Humana no Projeto Fotográfico de Victor Frond. Apud SALGUEIRO, op cit, nota 11, p 131.

40 GUSDORF, George. Le savoir romantique de la natur. Payot : Paris, 1985.
} 
Entretanto, essa natureza que parece ser apreendida sem mediações fora preparada para ser percebida, os modelos haviam se instalado há muito tempo, sofrendo atualizações nas suas recepções; um singular estado harmônico que repercute chaves clássicas uma vez mais, como acontecerá, por exemplo, em relação à figura do sublime. A paisagem tornou-se capaz de incorporar o que fora uma vez percebido como assustador e desmedido, o principio orgânico une as manifestações assimétricas e naturaliza o desastre.

É na dimensão da paisagem que se estabelecerá a união mais singular: o artista inspirado não se diferenciará do vulgo, afirma Simmel 41: na contemplação da paisagem todos somos artistas em potência. No momento em que a separação entre homem e mundo se reforça concretamente nas instâncias da vida comum e especialmente pelo saber científico, a paisagem aparece como esse elo, a trama que resiste à separação e a possibilidade de comunhão dos homens com o mundo através de sua presença maior: a experiência da natureza tornada paisagem.

a paisagem e o moderno

A pretensa ruptura que possa significar o Modernismo ${ }^{42}$ em relação ao passado e à história será apresentada uma vez mais pelo jardim; entretanto, é a paisagem em suas formas complexas que resistirá ao esvaziamento provocado pelo desenvolver desse período.

A teoria do Jardim Moderno nunca foi sistematizada, embora sua prática tenha concentrado questões importantes do século XX 43; essa afirmação de Jane Brown é apresentada junto à hipótese de que é na América que esse jardim alcançará sua autentica potência, até ser convertido numa interpretação (sic) de paisagem moderna, tendo seu ocaso dez anos depois de haver sido reexportado para a Europa do pós-guerra. Suscetível

41 SIMMEL, George. Filosofia da Paisagem, in O Indivíduo e a Liberdade, Ensaios de Crítica e Cultura, Barcelona, 1986, pp 175 e ss.

42 "Sob o nome genérico de Modernismo resumem-se as correntes artísticas que, nas últimas década do século XIX e na primeira do século XX, propõem-se a interpretar, apoiar e acompanhar o esforço progressista, econômico-tecnológico da civilização industria. São comuns às tendências modernistas: fazer uma arte em conformidade com sua época e a renúncia a evocação de modelos clássicos..." ARGAN, Giulio Carlo. Arte Moderna. p 185.

43 BROWN, Jane. El Jardín Moderno. Introdução. Barcelona : Gustavo Gili, 2000. 
ao clima e a especificidades geográficas, o jardim é um desdobro de sua localidade: solo, clima, geografia são informações fundamentais, o que leva à percepção das particularidades de cada lugar e ao desafio de pretensões a uma suposta internacionalidade.

A paradigmática mostra acorrida em Paris, Exposition des Arts Décoratifs de 1925, apresenta exemplares dos espaços livres entre arquiteturas revolucionárias que pretendiam localizar o jardim em novo patamar; do lugar associado ao privilégio à expressão da continuidade entre exterior e interior submetidos à mesma razão moderna que atacaria o urbanismo culturalista, as cidades jardins e o próprio jardim como afetação elitista nos Congressos Internacionais de Arquitetura Moderna, CIAM.

A disposição desses jardins na mostra foi dirigida por Jean Claude Nicolas Forestier ${ }^{44}$, (1861-1930),

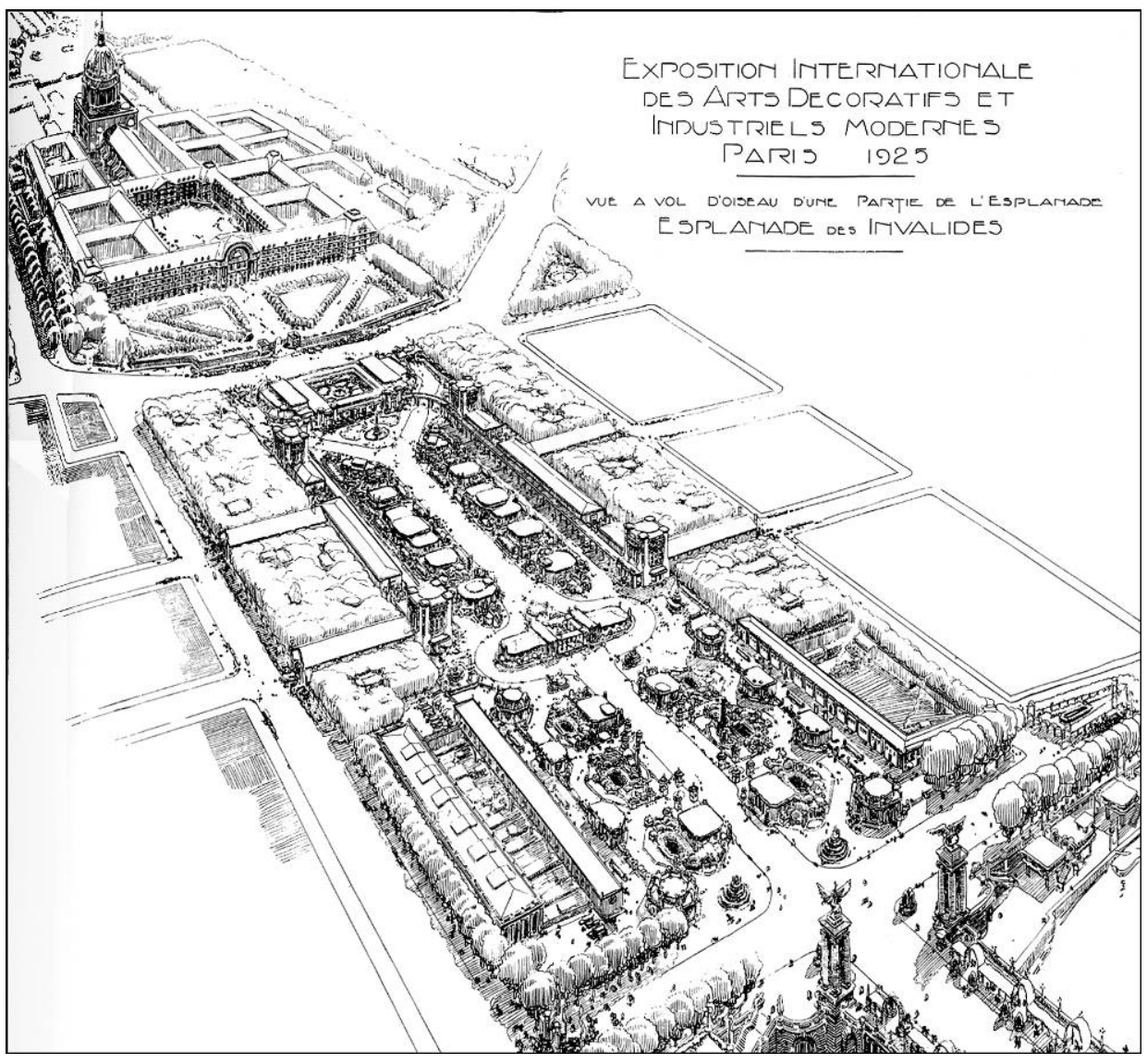

fig. 2 - Exposição Internacional de Artes Decorativas e Industriais Modernas - Paris 1925

44 O currículo de Forestier inclui o Campo de Marte, (1908), projetos na Espanha, (os parques Maria-Luisa em Sevilha e Montjuich em Barcelona), Lisboa e Havana. "Mas Forestier não adere inteiramente a nenhuma dessas tendências. Evitando ambos extremos, ele desenha a partir dos dois estilos: paysager e régulier. Nessa posição, como administrador e designer, ele domina a evolução do jardim em França do jardim horticole do 
cujo singular percurso estabelece o contato entre chaves estéticas do período, relacionando-se tanto à escola herdeira de Adolphe Alphand, (1817-1891), e à tradição urbana de projetos de parques segundo o modelo paisagístico, quanto ao retorno do formalismo do final do século XIX, propostos especialmente por Henri e Achille Duchêne.

A Exposição de Artes Decorativas apresentou nomes de vanguarda na arte dos jardins como Mallet-Stevens, Guevrékian e os irmãos Vera. O conjunto das intervenções causou revolta, comoção e críticas. A reflexão mais comum acerca desses exemplos é que seu grau de abstração causava estranhamento, como se as pinturas do cubismo geométrico em precisas linhas tivessem sido lançadas à tridimensionalidade, o que resultava num espaço ao qual carecia proximidade com o real. Esse, de qualquer modo, não era o ponto para esses criadores: essa realidade propunha uma vida que aconteceria sob novas bases relacionadas ao standart e às séries, à simplicidade geométrica e ao progresso. A proposta não perdura, e seu ocaso relaciona-se às próprias qualidades formais que a constituem, à permanência de certos modelos nos quais o paisagístico enquanto estilo aparece, e à definidora mudança do foco dos debates estéticos para os programas de vinculação social.

Contudo, o jardim paisagístico, tributário do pinturesco inglês e grande motivo de desenho dos parques dos finais do século XIX, está excluído dos debates acerca da modernidade, deixando de participar do debate estético e do pensamento arquitetônico. Esse

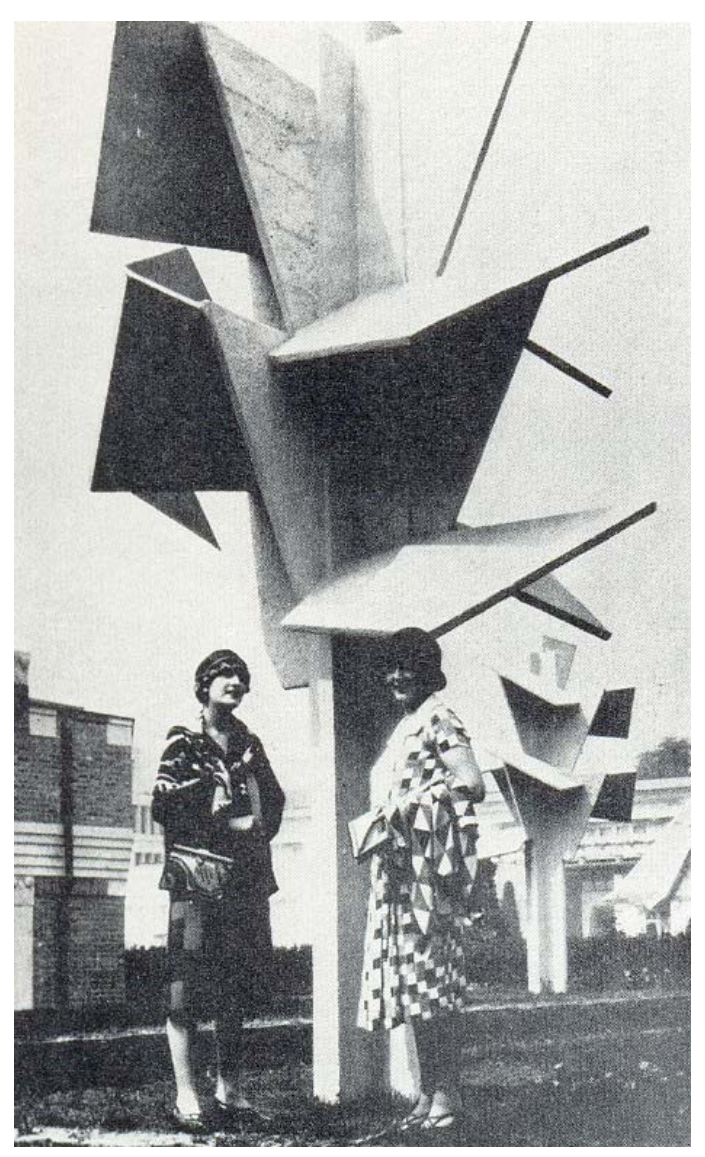

fig. 3 - Árvores de concreto de Jan e Joel Martel nos jardins de Mallet-Stevens

segundo Império para o exercício Cubista/Modernista de 1920." In IMBERT, Dorothée, The Modernist Garden in France. Yale University Press : New Haven and London, 1993. 
desaparecimento liga-se não só a sua possível associação ao histórico e à tradição, mas também a um processo que passa a perceber esses lugares que anteriormente tinha dimensão e significado na vida das pessoas, como o informe espaço verde. De fato, é toda a questão do jardim em particular e da paisagem de modo geral que são atingidos por esse esvaziamento associado ao fenômeno de supremacia da técnica e conseqüente crescimento da figura do planejamento 45 .

Nesse complexo desenvolvimento, a paisagem vê seu matiz tornar-se crescentemente científico e suas qualidades artísticas serem subsumidas como correlatas, ou inerentes à técnica; a paisagem como meioambiente é uma construção que se apresenta como contraparte do desenvolvimento científico. 0 termo meioambiente, também complexo e inclusivo, parece querer guardar a síntese do que seja natureza e paisagem; estende-se, parece englobar essas idéias. Porém, trata-se de uma equivalência com pretensas dimensões culturais, e implica numa redução da paisagem em sua poética e estética como questões menores, ou mesmo desprovidas de sentido, estetismo inútil 46.

A hipótese culturalista postula a necessidade de investigação do que venha a ser paisagem ${ }^{47}$, procurando elaborar sua atualização a partir de investigações estéticas; para a prática profissional do arquiteto da paisagem, a vinculação a essa chave se traduz pela dialética recusa do selo ambientalista, ao mesmo tempo em que afirma a necessária compreensão das lógicas atinentes ao meio ambiente.

45“O espaço verde é um conceito nascido com o planejamento urbano, (...) em inícios de 1910, surge uma específica linguagem, resultado do esforço teórico de racionalização buscado para regular as desorganizadas flutuações da cidade moderna dividindo o território de acordo com a segregadora idéia de zooning, (...). A redução do jardim ao verde poderia não ter sido catastrófica, afinal tratava-se apenas de uma questão de modo lingüístico, uma peça do discurso técnico em processo de codificação. Mas infelizmente, isso ocorre dentro da perspectiva da mais poderosa das tendências das vanguardas artísticas entre guerras: a condenação da ornamentação, cubismo, neoplasticismo e abstração. Essa colisão toma forma de fusão inscrita no desejo desses movimentos de romper com a tradição, inventando a visível modernidade.". In LE DANTEC, op cit, pp 228 e 229.

46 CAUQUELIN, op cit, p 10.

47 "É moda hoje em dia na Europa ocidental denunciar e anunciar a morte da paisagem. Não acredito em nada disso. Longe de se empobrecer, nossa visão da paisagem não cessa de se enriquecer, a ponto dessa exuberância - cada década nos confia já seu lote de novas paisagens, onde a arte e a técnica se prestam mútuo apoio - arriscar de nos sobrecarregar os olhos e de provocar, com a saciedade, a nostalgia de tempos quando, sozinho, o campo bucólico, querido de certos ecologistas, tinha direito de cidadania em nossa visão estética. A invasão dos meios audiovisuais, a aceleração das velocidades, as conquistas espaciais e abissais nos abriram e nos forçaram a viver em novas paisagens, subterrâneas, submarinas, aéreas, planetárias... Paisagens sonoras, as soundscapes de Murray Schafer, olfativas, smellscapes de Nathalie Poiret, cinestésicas, coenestésicas, para não evocar as paisagens virtuais..." ROGER, in SALGUEIRO, op cit, p 38. 
Na contramão dos abstratos espaços verdes dos planos, a sensível e mediada construção de uma paisagem que inclui espaços livres e edificados, a compreensão possível de suas lógicas e a proposição de um lugar, nova paisagem. 0 que não pode ser descartada é a dimensão de arte, a construção estética, cultural e histórica presente nessa ação de projeto.

O debate atual sobre a paisagem, a partir de falas que pretendem inseri-la uma vez mais dentro do contexto cultural posterior ao Moderno, está baseado num simples tom, mas este com infinitas ressonâncias: o confronto entre o dado e o artifício, o naturalmente colocado em relação aos esforços da cultura 48. Essa investigação procura rearticular as valências neutralizadas enfatizando uma vez mais o contato entre as questões da natureza e da arte.

De modo que o percurso nesse momento investiga outro dos pontos que alicerçam nossa questão, a saber, a idéia de Natureza e suas dimensões.

48 In LE DANTEC, op cit, p 233. 


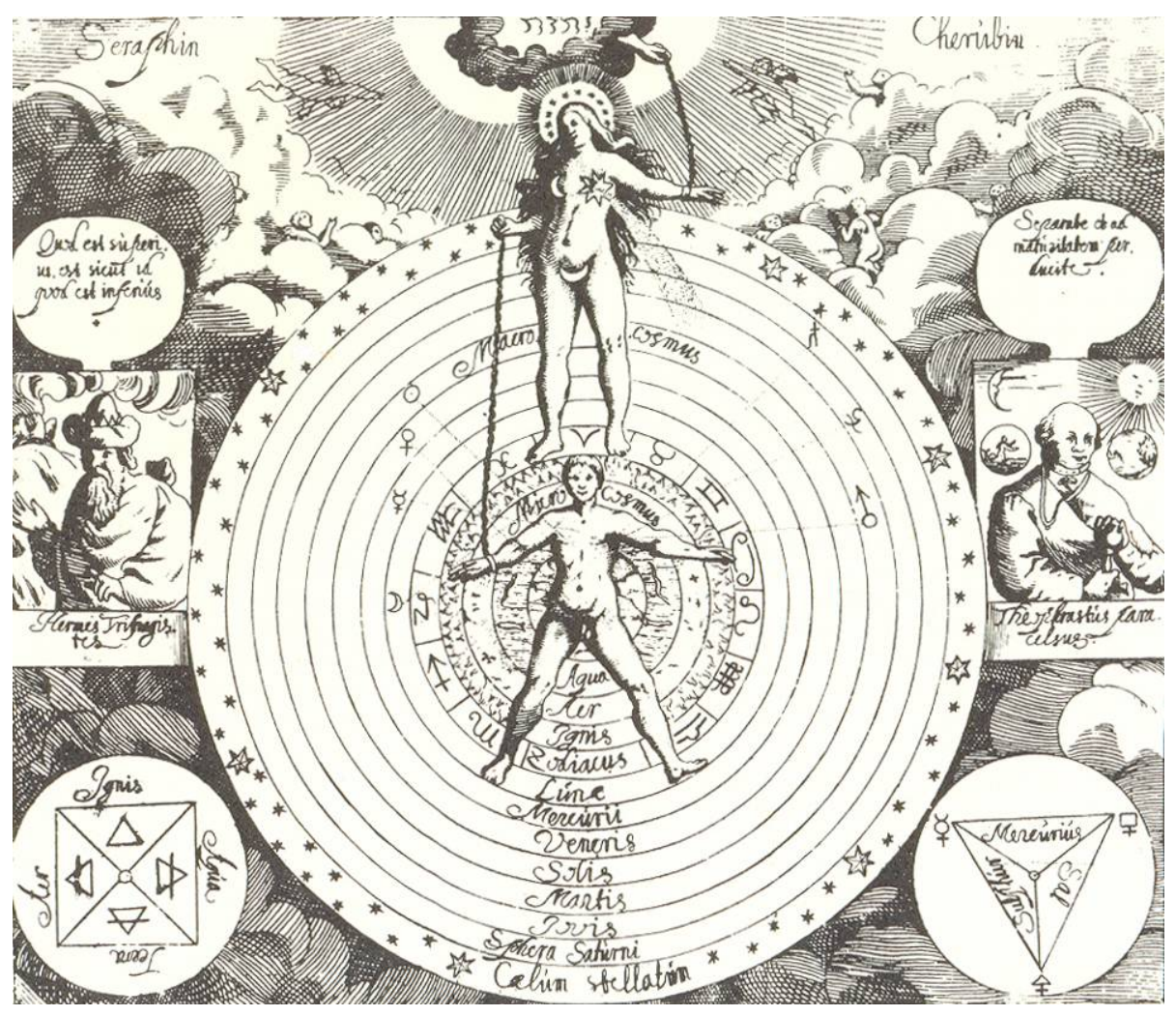

NATUREZA 
A Natureza é um objeto enigmático, um objeto que não é inteiramente objeto, seu sentido existe, mesmo na ausência do pensamento que o elabore; a natureza não está inteiramente diante de nós, como objeto em separado. É nosso solo, não aquilo que está adiante, mas aquilo que nos sustenta. ${ }^{1}$

\section{natureza, entre a origem e sua transformação em objeto}

A idéia de Natureza se altera no decorrer da história do pensamento humano, trata-se de um termo que já apresenta significados múltiplos desde sua origem ocidental. Na língua grega se associa ao vegetal a partir da palavra phýsis, embora nos pré-socráticos essa phýsis já signifique a totalidade das coisas - para os estóicos, por exemplo, a Natureza expressa, inclusive, uma idéia de ordem atinente a essa totalidade.

Em Aristóteles, “...a Natureza é o princípio e a causa de movimento e do repouso da coisa à qual reside imediatamente e na qualidade de atributo essencial e não acidental dessa coisa" 2; há pois, um sentido de orientação e essência que veremos reaparecer sob a forma de destino noutra chave semântica.

A cultura grega também trata a Natureza através da retórica e suas figuras. No mesmo Aristóteles a Natureza é relacionada pela metáfora à boa dona de casa, aquela que dispõe de suas reservas da melhor forma possível, embora sempre haja espaço para o acaso no privilégio de alguns, e na falta para outros... De maneira que os acidentes são encarados como questões correntes pelas quais passam tanto as gestoras do lar, quanto a Natureza. Contudo, de modo geral, cúmplices da vida, tanto uma, como outra, a mãe natureza e a senhora da casa, aquinhoa seus entes de modo a levarem suas vidas na conformidade ${ }^{3}$.

Do latim temos a raiz da palavra como aparecerá na língua Portuguesa: nascor, da qual derivará nascer, cujo significado está na direção de um sentido primeiro, de origem ${ }^{4}$. 0 romano Cícero denominava a paisagem

\footnotetext{
1 MERLEAU-PONTY, Maurice, in A Natureza. São Paulo : Martins Fontes, 2000.

2 Aristóteles, Física II, 192 b 20.

3 CAUQUELIN, op cit, p 45.

4 Verbete Natureza, in Dicionário de Filosofia de Nicola Abbagnano. São Paulo : Mestre Jou, 1982.
} 
cultural, construída, de segunda natureza, como aquela que é fruto do artifício humano. Essa idéia implica numa natureza primeira, um mundo anterior à alteração humana, uma origem que coincidiria com o selvagem, sobre o qual não deitara ainda o artifício $^{5}$ e é essa que se vê perpetuar-se em detrimento da segunda.

O livro de Robert Lenoble, História da Idéia de Natureza, 6 estabelece um primeiro período quando a concepção de Natureza fora anímica e relacionada aos temores humanos frente ao desconhecido, algo que corresponderia ao período anterior ao florescimento da filosofia e da Pólis. Em Aristóteles não se trata mais da relação entre fenômenos da Natureza e divindades, mas um outro tipo de analogia que observa a Natureza e percebe na sua hierarquia uma possível correspondência com a sociedade e sua organização. Lenoble distingue a Natureza dos antigos daquela que será instituída pela cristandade; o destino cristão se projeta para um tempo no qual não existiria a Natureza e nem mesmo o tempo. A origem está em Deus e a partir dele que, eterno, é criador e anterior a essa nova e finita Natureza construída pela Igreja 7.

No século XII, a Natureza do medievo é hostil e permanece, ou parece estar, do lado de fora dos muros que cercam a cidade; esta reproduz pequenos idílios de uma Natureza perdida, anterior talvez à maçã e à queda, mas conquistada pelas ilustrações, pinturas e tapeçarias. 0 que comparece nos espaços livres de edificação dessas cidades comumente muradas $^{8}$ é a presença humana nas ruas e praças posteriormente chamadas secas, significando a ausência de vegetação, que estaria circunscrita aos pequenos pomares e hortas das abadias e casas senhoriais. A percepção de natureza nesse momento transita entre a possível experiência do não dominado, o mundo exterior, e uma projeção de natureza associada ao privilegio do pequeno jardim, portanto a uma paisagem construída, mediada pela representação.

\footnotetext{
5 HUNT, John Dixon. Gardens and the Picturesque. Studies in History of Landscape Architecture, The MIT Press : Cambridge/Massachussets, 1992, pp 3 e 4.

6 LENOBLE, Robert. História da Idéia de Natureza. Edições 70 : Lisboa, 1969.

7 "Nada menos familiar ao pensamento antigo. A Natureza é o todo, sempre existiu, sempre existirá, é nela que o homem encontra sua realização". LENOBLE, op cit, p 189.

80 estudo realizado por Jacques Le Goff e Cesare de Seta, A Ciudad y las Murallas, Catedra : Madrid, 1989, relaciona o fenômeno urbano e a construção de muralhas, contemplando um longo período da antiguidade tardia ao século XIX. Aqui interessa a questão da muralha e seu papel de circunscrever a cidade, limite entre o exterior /selvagem e o interior /refúgio; entre a fome e a segurança do lugar no qual se dão as trocas. A muralha como imagem é aquela que estabelece a razão de ser da cidade, contraponto entre o natural e o civilizado.
} 
Essa visível incompatibilidade entre uma natureza criada por Deus em sua perfeição e essa que o homem desses tempos é capaz de experimentar, fonte de temor, forja o cenário para uma distinção que atravessará séculos; a reflexão acerca da Natureza a desdobra em duas naturezas: a partir de Averróis, século XII, passando por Santo Tomás de Aquino até Espinosa no século XVII, de um lado a Natura naturans, ou naturante, perfeita expressão do próprio poder criador de Deus, e a Natura naturata, como a totalidade das coisas, essas naturalmente corrompidas.

Pensadores irão associar a cada uma dessas compreensões outras questões. Dante Alighieri na Divina Comédia torna a Natureza profundamente cristã enquanto comunhão, punindo nos três últimos círculos do inferno a violência que destrói a Natureza, o ateísmo e a violência contra a verdade e o instinto;

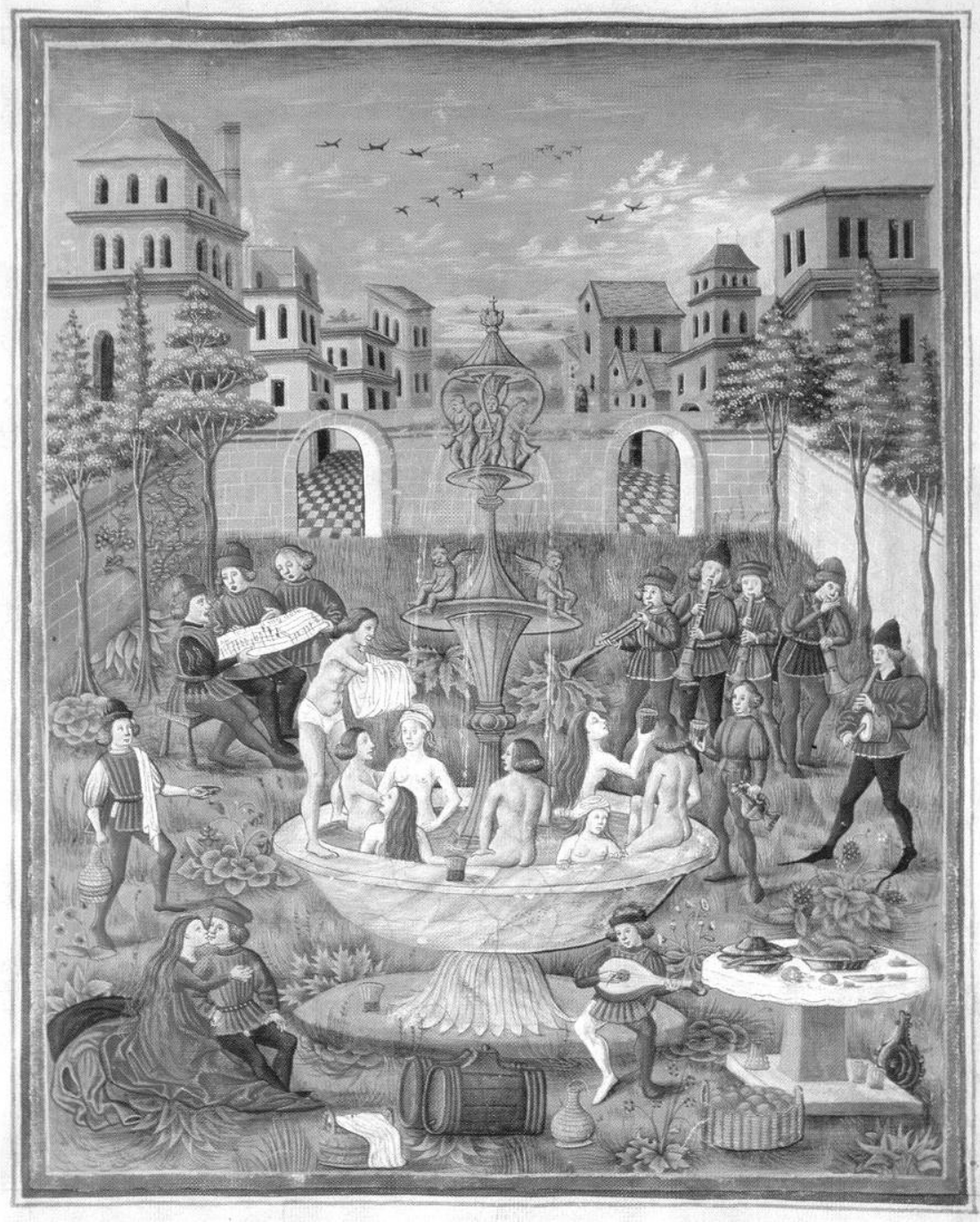

fig. 4 - Fonte da juventude miniatura da De Sphaera ele não só distinguiria a Natureza daquela que Santo Ambrósio qualifica como danação e negativo devir, como afirmaria ser o desenvolvimento humano parte dessa Natureza. Trata-se de um embate que afirma de um lado 
uma natureza como lócus de desenvolvimento e constituição; e de outro que vislumbra na natureza o lugar da corrupção.

O período relacionado ao chamado Renascimento, que interpreta e por vezes elabora a Antiguidade como se viu no capítulo sobre a paisagem, termina por nublar a Natureza presente em Dante, relacionada à totalidade e construção, e a apresenta na direção de um pensador anterior ao próprio Santo Ambrósio. Segundo o argumento de Lenoble, é a partir de Lucrécio ${ }^{9}$, romano, contemporâneo de César e de um tempo no qual as liberdades estão em declínio, que se desenvolve a idéia dominante que se terá sobre Natureza a partir desse período. Leitor e admirador do grego Epicuro, Lucrécio sustenta a compreensão de um mundo imune aos caprichos dos deuses, defendendo uma ciência cuja base não estivesse calcada nos astros e oráculos, essa percepção de mundo seria passível de ser associada à concepção mecanicista 10 que será desenvolvida a partir do século XVII.

Embora a ordem cósmica ainda seja garantida pela figura de Deus no século XVII ${ }^{11}$, a concepção mecanicista que se desenvolve, o mundo como uma grande máquina, percebe uma Natureza que participa e expressa essa lógica. A diferença vital está no fato da entrada em cena de um Deus cuja perfeição tem paralelo na matemática, que é conquista do engenho humano; a partir disso, uma compreensão de Natureza como mecanismo a ser investigado e mesmo ratificado pela ciência e pela técnica, trata-se de encontrar a justa medida que desvenda a ordem que ali guardada.

Merleau-Ponty atribui à René Descartes, nesse século XVII, a primeira formulação de uma nova idéia de Natureza. Ainda que mais uma vez a extraia da idéia de Deus, a Natureza será sua imagem: uma realização

\footnotetext{
9 Apenas uma cópia do De rerum natura de Lucretius, (99-55 aC), sobreviveu à antiguidade, descoberta por Poggio Bracciolini, (1380-1459), em 1417; a busca de manuscritos antigos guarda passagens dramáticas como o naufrágio do navio vindo de Constantinopla, de Jacopo Ângelo em 1406, e o resgate da Geografia de Ptolomeu ainda desconhecida no Ocidente de então. DEBUS, op cit, pp 4 e 5.

10 "Lucrécio exibe as reconhecíveis marcas de um espírito científico: ele observa o mundo natural criticamente, e insiste na universalidade das causas naturais, (...). Seu trabalho, 'Sobre a Natureza do Universo'(...)o instala entre os precursores das publicações científicas modernas”. HEALY, John F. "Introduction”, in PLINY, THE ELDER, op cit, p xvii.

11 o Cosmos é obra sublime de um Deus artista em finais do século XVI. As chaves herméticas, mitos e alegorias, perderão sua força a partir do desenvolvimento técnico científico, de modo que o pensamento humanista procurará ler a Natureza a partir do mesmo lugar que o pensamento: a mente reconhece nessa Natureza a ordem que tudo conforma, inclusive a si própria. Cf. SILVESTRI e ALIATA, op cit, p 43.
} 
exterior de uma racionalidade que está em Deus. Para Descartes, a Natureza e o homem não estão mais num mesmo plano, o cogito é anterior e a Natureza é exterioridade regida a partir de um sistema de leis derivadas de um Deus infinito e perfeito ${ }^{12}$.

O século XVIII é comumente descrito como profundamente anti-cartesiano uma vez que os intelectuais ligados à Encyclopedie condenam o esforço de Descartes em ligar física e metafísica, e de fato nesse século se projeta a ruptura dessa relação: Natureza e Deus serão duas chaves não necessariamente comunicantes. A Natureza tornar-se-á nesse tempo distinta não só de Deus, mas também do Homem, de modo que é através da completa separação que se tem a possibilidade de fazê-la objeto de uma ciência desencantada.

Seria possível pensar que a idéia de Natureza se alterou a partir do desenvolvimento técnico e tecnológico, em outras palavras, é porque descobrimos coisas e inferimos acerca dessas descobertas que o chamado mundo natural e a própria idéia de Natureza foi sofrendo modificações, desde sua origem anímica até sua transformação em objeto, destacada do homem e de Deus. Contudo, a filosofia da ciência testemunha o contrário: não foram as descobertas científicas que provocaram a mudança da idéia de Natureza, mas sim as mudanças da idéia de Natureza que tornaram possiveis as descobertas: porque se foi capaz de pensar num mundo que não fosse plano, que a idéia das circunavegações deixou de ser absurda viagem ao abismo; foi porque se ousou pensar numa lógica que deslocou a Terra do centro do universo, que um novo céu se tornou visível ${ }^{13}$.

natureza, arte e ilustração: século XVIII

Do início do século XVII aos finais do XVIII, uma mudança significativa ocorrerá na base do conhecimento a partir da chamada llustração ${ }^{14}$. Os letrados das luzes procuram desvendar o mundo como algo apreensível,

12 MERLEAU-PONTY, op cit, p 10. Embora a idéia de Natureza como algo inteiramente exterior tenha sua primeira manifestação já nos estóicos, e seja defendida também por Lucrécio, séc I, a construção cartesiana a partir do cogito garante-lhe a originalidade segundo o autor.

13 KOYRÉ, Alexandre. Do Mundo Fechado ao Universo Infinito. Rio de Janeiro: Forense, 1979.

14 "A progressiva laicização promovida pelos autores da llustração leva a que não mais se atribua a fins situados em algum além imponderável o fundamento e o horizonte da ordem social, (...). Em vez das complicadas e abstrusas regras vassalas de superstições, tradições, convenções ou 
afastando-se das pretensas explicações religiosas ou metafísicas em geral, e afirmando uma razão capaz de realizar essa tarefa. As teorias newtonianas fazem crer numa organização do mundo e do universo aos quais, analogamente, são propostos ordenamentos para as demais instâncias da sociedade 15 .

Três princípios referendam o horizonte desses tempos llustrados e permitem o contato e analogias entre campos do conhecimento: toda pergunta de caráter genuíno é passível de ser respondida, se não agora, em algum outro tempo; a segunda das proposições afirma que todas as respostas são cognosciveis e podem ser descobertos os meios de ensiná-las, em resumo, o conhecimento seria transmissível e não revelado; e finalmente a terceira assevera o fato de que todas as respostas obtidas devem ser compatíveis entre si, significando que, proposições, desde que verdadeiras, não se contradizem 16 .

Immanuel Kant, 1724-1804, difunde essa qualidade do conhecimento afirmando estar o fenômeno subsumido a leis ${ }^{17}$. 0 homem livre, emancipado pela razão, é aquele que percebe e recorta a constância de um evento, escolhe e distingue segundo julgamento, e elabora a lei. A natureza aqui deixará de ser imagem de Deus para ser objeto da razão humana e seus princípios devem ser expressos através de enunciados racionais.

A razão universal que tudo perpassa postula uma natureza equânime, que distribui seus dons de maneira equilibrada, que provê e promove seus seres. Essa analogia constitui o centro da argumentação acerca da igualdade entre os homens, uma ordenação social justa tinha como mote fundamental a lei natural. Entretanto, a reunião de pensadores tão diversos sob o mesmo movimento denota a complexidade do período; a pretensa convergência entre a totalidade de seus participantes quer seja sobre o tema Razão, quer seja acerca do tema

modas, difundidas nos tempos do Ancien Régime -, aspira-se por uma ordenação social regida com simplicidade pelo bom senso e pela lei natural". AZEVEDO, op cit, pp 5 e 6.

15 Sir Isaac Newton, (1642 - 1727), demonstrou existir um equilíbrio dinâmico atinente ao sistema solar e, portanto, ao Universo, apreensível pela razão. "Com poucos movimentos magistrais, Newton logrou reduzir este enorme caos em uma relativa ordem. Ele havia sido capaz de deduzir com umas poucas proposições físico- matemáticas a posição e velocidade de toda partícula do universo; (...)se esse tipo de ordem poderia instituir-se no mundo da física, os mesmos métodos poderiam produzir resultados equivalentes - esplendidos e permanentes - no mundo da moral, da política, da estética, e no resto do caótico mundo da opinião humana”. BERLIN, op cit , pp 46 e 47.

16 BERLIN, op cit, p 43.

17 "Pela expressão Natureza entendemos a conexão dos fenômenos, por sua existência segundo regras necessárias, ou leis. Existem, portanto, certas leis, e leis a priori, que tornam antes de tudo possivel uma Natureza; as leis empíricas podem estar aí e serem descobertas somente através da experiência...". Crítica da Razão Pura, cap II, terceira analogia. KANT apud MERLEAU-PONTY, op cit, p 57. 
Natureza, nubla-se quando diminuída a distância e observadas as mediações realizadas por cada um deles. Pense-se na coexistência de Rousseau e sua natureza harmônica e na desconfiança de Voltaire sobre uma natureza capaz de causar morte e dor como nos terremotos em Lisboa.

Para a construção pretendida nesse trabalho, o foco de atenção volta-se para Rousseau; sua idéia de Natureza será informação vital para os desenvolvimentos posteriores acerca da paisagem e sua arquitetura.

Também o significado de lei natural para Rousseau difere substancialmente da definição de Kant. Segundo Rousseau a lei natural não é um enunciado exposto na língua da reflexão filosófica. Para ser ouvida e seguida, ela não requer nenhum saber ${ }^{18}$. No desenvolvimento intitulado $A$ voz da natureza, o pensador Jean Starobinski apresenta o convite feito por Rousseau para que se procure por essa lei natural aquém do reino humano da palavra; contrariamente aos recursos discursivos que procuram definir a lei, ele propõe a ausência de mediação: por definição a voz da natureza deve falar antes de toda palavra.

A Natureza é necessidade, ela clama por satisfação, comanda o animal; o homem é livre para optar pela decisão moral, tomando posse de sua vontade, cede ou recusa à pressão que a necessidade imprime. A elaboração de Jean-Jacques define o homem em primeiro lugar não porque fala, mas porque escuta. Para ele a voz da natureza é uma informação que não se inscreve diretamente na forma do comportamento ${ }^{19}$, porque se estivesse inscrita seria instinto, necessidade pura. Contudo, se a mediação inexiste não se trata de um emissor e um receptor, esse ato de ouvir falar a natureza é algo que repercute no próprio homem: é nele próprio que o homem percebe a voz da natureza.

A contraparte dessa argumentação localiza o homem civilizado como aquele que se tornou incapaz de reconhecer essa voz: ao trabalhar contra ela, ao interpor a linguagem de que é inventor, o homem torna-se surdo à voz que Ihe falava na origem. A existência moral não é mais regida pela lei natural: é preciso enunciar lei positivas, convenções, contratos. Quando isso acontece discursos de outra natureza argumentativa são

18 STAROBINSKI, Jean. Jean-Jacques Rousseau: a transparência e o obstáculo; seguido de sete ensaios sobre Rousseau, São Paulo : Companhia das Letras, 1991, p 312.

19 STAROBINSKI, op cit, p 313. 
necessários para que se redescubra, se relembre o que foi apagado: o filósofo é esse grande mediador para Rousseau: necessário à sociedade, é ele que torna audível, uma vez mais, a voz da natureza.

Porém, por mais que Rousseau se considerasse solitário como alguém reprovado por toda uma geração 20 , o século XVIII, a par de ser aquele combate às crenças sem fundamento, também exalta o profícuo consórcio de Entendimento e Sentimento. A Razão desses tempos não negligencia as nuanças da Sensibilidade ou aos contrastes da Imaginação, pois é por elas que se gestam o arrebatamento e o entusiasmo - possessão divina a que aspira a alma. É próprio, destarte, à Arte o telos de capturar e cativar o interesse do homem de gosto, de potencializar a superação das reiterações do habitual e sobretudo, de facultar à alma o desjungir-se do tédio 21 .

Há espaço para a imprecisão nessa Razão ilustrada, uma percepção de que existe uma parte da experiência e mesmo do conhecimento que não é operado pela razão, enquanto clareza e distinção. Trata-se de uma cognição confusa porque dependente das relações e sugestões que a conformam e que possam surgir a partir dela 22.

Kant argumentaria na defesa da individualidade do gosto: não há ciência do belo, mas apenas sua crítica uma vez seu motivo determinante é o sentimento do sujeito e não o conceito do objeto. A beleza se revela numa ordem sem conceito, cabe ao juízo revelar seu significado ${ }^{23}$. De maneira que a natureza em Kant será bela quando possuir aspecto de arte, em outras palavras, quando mediada por esse jogo que conspira pela harmonia do todo e que reverbera no espírito pois, o que se pretende da arte é que ela seja capaz de comover e nos sacar do tédio que sempre espreita 24 .

20 STAROBINSKI, op cit, p 267.

21 AZEVEDO, op cit, p 18.

22 "O sentimento está sempre certo - porque o sentimento não tem outro referente senão ele mesmo, e é sempre real, quando alguém tem consciência dele. (...) Ele se limita a assinalar uma certa conformidade, ou relação entre o objeto e os órgãos ou faculdades do espírito, e, se essa conformidade não existisse, o sentimento jamais poderia ter ocorrido. A beleza não é uma qualidade das próprias coisas, existe apenas no espírito de quem as contempla, e cada espírito percebe uma beleza diferente." HUME, David. Do Padrão do Gosto, apud AZEVEDO op cit, p 14.

23 JUSTINO, Maria José. Criticar é... entrar na crise. In GONÇALVES, Lisbeth R. e FABRIS, Annateresa. Os Lugares da Critica de Arte. São Paulo : Imprensa Oficial, 2005.

24 "Cabe dizer que, no concernente às Artes e às suas preceptivas, - rebelando-se contra a rigidez dos sistemas que transitaram pelo século XVII-, o XVIII não teria sido, como se propala, apenas o século da Razão, mas também o da Comoção." AZEVEDO, op cit, p 19. 
Certas filosofias, como as de Hobbes e Locke, informam a cultura e engendram uma lógica que ganhou espaço crescente: a personalidade como uma forma alterável a partir de padrões institucionais, o que significa acreditar que os mecanismos da sociedade são capazes de moldar o homem. Também reagem os filósofos idealistas alemães no século XVIII contra essa vaga que emudece as particularidades do ser humano, eles clamam pela capacidade individual e pela liberdade desse indivíduo de utilizar seus poderes imaginativos na apreensão das razões que controlam o universo. Esse grupo de homens, contrários à percepção de uma humanidade homogenia, informará o Romantismo elaborando sobre uma individualidade especial, mais apurada que as outras e a própria expressão da natureza em si, de modo que são eles potencialmente capazes de mudar a sociedade 25 .

O chamado movimento Romântico é constituído dentro da perspectiva de reação ao mecanicismo e seus desdobramentos tornaram a existência da Natureza algo em separado 26 . Na carta número $\mathrm{VI}$ de $A$ Educação Estética do Homem, Schiller, (1759-1805), assinala o ponto de separação e a possível volta a um estado de união entre Homem e Natureza: a cultura abrira a fenda, o desenvolvimento de uma racionalidade mecanicista afastara o homem desse estado primeiro e verdadeiro ${ }^{27}$. Para o idealismo alemão, o restabelecimento de uma totalidade destruída pelo artifício do pensamento depende de coragem e criação.

O desafio é retornar a um pretenso estado original no qual inexistira a separação, sem contudo recair na infantilidade anterior à autonomia conquistada pela razão. A estratégia para alcançar essa reconciliação entre homem e natureza logra-se pela arte. A Spieltrieb proposta por Schiller é a adoção de uma atitude ou instinto

25 “Para os românticos é o indivíduo, através do seu gênio, que molda a sociedade e cria os símbolos que inspiram à ação." FISHER, Irwing. Frederick Law Olmsted and the City Planning Moviment. Michigan : Columbia University, 1976, p 38.

${ }^{26}$ A ligação entre Idealismo alemão, Romantismo e a filosofia de Rousseau, transparece na poética de Hölderlin: Rousseau é um "filho da Terra", um semideus que fala numa loucura divina, como Dionísio. É um dos eleitos que podem sem esforço acolher o Todo, que carregam nos ombros o peso do céu e da alegria, HÖLDERLIN apud STAROBINSKI, op cit, p 268.

27 "Por que o indivíduo grego era capaz de representar seu tempo, e porque não pode ousá-lo o indivíduo moderno? Porque ele recebia suas forças da natureza, que tudo une, enquanto este as recebe do entendimento que tudo separa. Foi a própria cultura que abriu essa fenda na humanidade moderna. (...) O entendimento intuitivo e o especulativo dividiram-se como intenções belicosas em campos opostos" . SCHILLER, Friedrich. A Educação Estética do Homem. São Paulo : Iluminuras, 1995, p 41. 
dos jogadores, algo que remete à proposição kantiana de compreensão da arte como jogo no qual as partes concorrem na direção de uma harmonia entre o objeto que se produz e o espírito que o apreende. Entretanto, há o afastamento de Kant quando Schiller afirma a criação ${ }^{28}$. A questão instintiva que permeia a atitude do jogador seria análoga à do gênio, nem sempre seus movimentos são frutos do cálculo, a intuição rege boa parte das ações, a natureza de suas decisões tateia o resultado pretendido. A arte é um jogo cuja principal qualidade é a liberdade e o decisivo entrave é reconciliar as necessidades da natureza da qual participa, às coerções criadas pelo artifício humano: A única maneira de lograr essa reconciliação é colocando-nos na posição de pessoas que imaginam ou que inventam livremente ${ }^{29}$.

O gênio criativo participa dessa totalidade como manifesta união entre matéria e espírito; através de uma ação que requer espontaneidade e intuição intelectual, sua imaginação parte do mundo da matéria e o transcende coincidindo com o domínio do espírito. Significa o reencontrar da própria natureza num estado indiviso no qual se exerce a percepção.

O ímpeto de Schiller inflama e apresenta uma possibilidade de retorno a um estado original, por sua vez a Natürphilosophie de Schelling, (1775-1854), apresenta a Natureza em nossa experiência perceptiva como fato anterior à reflexão: A Natureza para Schelling não é um produto, nem do capricho divino, nem da necessidade humana, essa Natureza está para além do mundo e aquém de Deus ${ }^{30}$. Essa percepção participa da construção de um Universo orgânico e sua força vital; sob essa perspectiva a Natureza se torna capaz de criar possibilidades de transcendência através de sua experiência: ela não é apenas a imagem da perfeição divina, ela é o meio pelo qual participo, estabeleço contato entre inconsciente e consciente, fala por mim essa grandiosidade e perfeição do próprio Universo.

\footnotetext{
28 Sobre a incisiva diferença que o separa de Kant afirma Schiller em Carta a F.H.Jacobi, de 29/06/1795: "Ali onde eu apenas destruo e procedo na ofensiva contra as opiniões doutrinais, sou rigorosamente kantiano; apenas ali onde eu construo, encontro-me em oposição à Kant”. Cf. nota 4, apud SCHILLER, op cit, p 12.

29 BERLIN, op cit, p 119.

30 Merleau-Ponty, op cit, p 60. A afirmação de uma não divisão entre matéria e espírito produz uma filosofia em contínua tensão e introduz a Natureza, sua compreensão e definição, na filosofia transcendental - sem transformar a Natureza em mera construção humana. Cf Lukács apud Merleau-Ponty, op cit p 82
} 
O Universo orgânico compreende e implica na transcendência entre o mundo material e o espiritual, o mundo objetivo é investido pelo espírito de modo que o que existe na mente humana e na natureza externa é essencialmente o mesmo ${ }^{31}$.

Schelling apresenta a resolução da dialética das oposições, sujeito/objeto, natureza/artifício, liberdade/necessidade, unificando os dois pólos numa teoria da identidade. A obra de arte, a criação artística, para esse autor não ocorre apenas em uma das instâncias, inconsciente ou consciente; sua força está justamente na união dessas duas ocorrências: o artista não está submetido à lei, a um modelo ditado pela razão, porém a consciência cria oportunamente as leis próprias ao desenvolvimento da energia inconsciente, a lei emerge do processo criativo.

Participante do círculo desses pensadores está o já mencionado Alexander von Humboldt. Nas intenções da publicação do segundo volume de Cosmos, em 1845, argumenta por uma experiência de Natureza que busca uma unidade que a simples utilização instrumentalizada da razão destrói. Ela procura antes, uma contemplação dos objetos naturais como meio de estimular o mais puro amor pela natureza, e investigar as causas deste, especialmente nesses tempos recentes, quando, pelo ativo recurso da imaginação, tão grandemente se encorajou o estudo da natureza e a predileção pelas viagens remotas ${ }^{32}$. Esse excerto testemunha questões que se tornaram correntes nesse século XVIII: a experiência da Natureza como uma necessidade, física e imaginativa, que se dá concretamente e pelas representações, literárias, pictóricas, artísticas enfim. São estratégias de aproximação dessa noção que se tornou poderosa matriz da vida, um sentimento e uma compreensão: Natureza, a um só tempo afeto e razão.

Referindo-se ao que se passa na segunda metade do século XVIII acerca da questão natureza e arte, Schiller afirmaria a potencial excelência desses tempos: a contemplação da natureza não fora de todo desconhecida

\footnotetext{
31 FISHER, op cit, p 38.

32 HUMBOLDT, Alexander von. Cosmos, a Sketch of a Physical Description of the Universe. Baltimore and London : The Johns Hopkins University Press, 1997, (1845),vol II, p 19.
} 
pelos antigos, o sentimento era, entretanto, muito mais raro e menos vívido que os expressos pelos tempos modernos ${ }^{33}$.

Essas questões são particularmente importantes para que se possa compreender as chaves estéticas que se desdobram a partir dessa singularidade de percepção defendida e operada pelos homens desse século, e que repercutem, sob alguma forma, até os tempos atuais.

Schelling torna-se referência para escritores americanos e ingleses no século XIX. Em suas formulações filosóficas que buscam o conhecimento através da intuição intelectual suplanta várias dualidades. A Natureza nessa construção identitária possuirá poderes sanificadores; a obra de arte, por sua vez, afirmaria Schelling, seria a mais pura expressão de uma filosofia natural incorporada pela identidade. 0 papel que Rousseau a princípio destacara como sendo a razão de ser do filósofo passa a ser também a expressão do gênio e sua arte. O esforço do artista, tanto quanto o do filósofo foi há um tempo, é revelar essa ordem que não é mais de matriz matemática, mas transcendente. Esse é o pivô do sistema do idealismo transcendental de Schelling: Arte como o organon universal da filosofia 34 .

Contemporâneo de Schiller, Johann Gottfried von Herder 35 elabora uma analogia a partir do crescimento semente como processo vital e espontâneo relacionada ao desenvolvimento do próprio ser humano, numa natureza compreendida como totalidade. Essas disposições são fundamentos gerais sob as quais teóricos e filósofos criarão aplicações particulares, especialmente no que diz respeito à natureza do gênio na arte. Elas também participam decisivamente dos autores que dão desenvolvimento ao chamado princípio orgânico, um tema recorrente no século XIX.

33 SCHILLER, Friedrich. Sämmtliche Werke, 1826, apud HUMBOLDT, op cit, p 21 e 22. Ao que soma Humboldt sobre os antigos nesse seu tempo tido como moderno: “...específicas descrições da natureza acontecem apenas como acessórios, porque, na arte Grega, todas as coisas estão centradas na esfera da vida humana. A descrição da natureza em suas múltipla riqueza de formas, como um distinto ramo da literatura poética, era completamente desconhecida pelos gregos."

34 SCHELLING, Friedrich W.J. von. "System des Trancendentalen Idealismus", Sämmtliche Werke, I, 3:624. Cf. nota 40 e 41, FISHER, op cit, pp 38 e 39.

35 Johann Gottfried von Herder, (1744-1803), foi contemporâneo de Schiller e promissor aluno de Kant. Intelectualmente influencia toda uma geração que inclui nomes como Humboldt e Goethe. A matriz filosófica de sua argumentação derivava de analogias construídas a partir da idéia de Natureza, sendo grande encorajador das questões democráticas ligadas à identidade de um povo e ao nacionalismo. 0 estudo do papel do inconsciente na formação de um povo e nação ganha força graças as suas disposições teóricas. 
Thomas Carlyle 36 é um dos primeiros a realizar o contato entre essas filosofias para cultura de língua inglesa em escritos de 1820. Sua obra Sartor Resartus apresenta uma teoria na qual o Universo orgânico liga-se ao trânsito inconsciente/consciente e têm na arte uma manifestação singular: Carlyle dá ao inconsciente uma posição privilegiada na atividade criativa ${ }^{37}$.

A visão orgânica de mundo e sua estreita ligação com o inconsciente orientarão toda a produção do pioneiro da arquitetura da paisagem Frederick Law Olmsted, (1822-1903). Muito embora não tenha sistematizado suas estratégias de ação e reflexão em projetos de espaços livres, é possivel reconstituir através de fragmentos presentes em sua correspondência e relatórios suas concepções relacionadas ao processo criativo. Entre suas leituras, existe a presença referenciada de Horace Bushnell, Thomas Carlyle, Samuel Coleridge, Ralph Emerson, leitor dos filósofos alemães em geral, e de Schelling em particular. Esses, ao lado de John Ruskin, seriam autores que Olmsted denominaria profetas, dada a qualidade e propriedade das informações que ele tivera acesso graças a eles.

Horace Bushnell, (1802-1876), teólogo e figura de referência na comunidade de Hartford onde viveu a família de Olmsted, faz em 1841 seu sermão sobre o tema da influência do inconsciente, delineando sua força como uma comunicação involuntária; uma espécie de simpatia que torna o inconsciente algo com dimensões bastante diferenciadas das do espectro romântico mais radical 38; em território americano a tradução do ideário alemão, especialmente vindo de Schelling, amplifica o matiz social: $O$ inconsciente absorve e sintetiza a experiência individual humana e é um reservatório de potencialidades que podem afetar o pensamento e o comportamento individual e de toda uma comunidade 39.

\footnotetext{
36 Thomas Carlyle, 1795-1881, é ensaísta e historiador escocês ligado à Universidade de Edimburgo que a partir de 1817 passa a ler e traduzir os filósofos alemães para a língua inglesa.

37 FISHER, op cit, p 53.

$38 \mathrm{O}$ inconsciente aqui expressa seu tormento e insatisfação congênita: a síndrome fundamental de Lord Byron diz respeito à impossibilidade de ajuste em relação a qualquer das estruturas presentes no mundo, algo que contagia o século e aparece em Lamartine, Vitor Hugo e Nodier. Schopenhauer representa a existência humana como uma frágil embarcação posta à deriva nas profundas águas da vontade; a questão que move todo o ciclo dos Nibelungos de Wagner é um desejo impossível de ser saciado. Cf. BERLIN, op cit, p 178.

390 ser humano não é moldável, mas seu inconsciente pode, e deve ser alimentado; afirmaria Olmsted em carta à irmã Bertha que viajava para a Europa em 1855: "Os melhores pensamentos nos vêm inconscientemente, não pelo estudo diretamente. Contudo, inteiramente sem o estudo
} 
Samuel Taylor Coleridge, (1772-1834), era ensaista, poeta e tradutor que passa a trabalhar os textos de Kant para a língua inglesa a partir de 1798. Amigo e companheiro de viagem de Wordsworth 40, concebe uma obra na qual compara poetas anteriores a atuais; segundo Coleridge o gênio é capaz de fundamentar sua obra dentro de parâmetros morais - Shakespeare faria seus leitores melhores e mais sábios; Milton tem trechos sublimes em seu Paradise Lost, 1670, nos quais se revelam a grandeza e pureza do espírito de seu autor.

A intensidade da relação de Olmsted com a estética romântica se ampliaria especialmente através de Ralph Emerson, que procurou demonstrar que a moralidade é o maior atributo do gênio. Porém, a mais forte posição acerca do propósito moral na arte parece vir do autor inglês do Modern Painters, John Ruskin ${ }^{41}$. Na primeira edição do livro nos Estados Unidos de 1847, Olmsted encontraria princípios atinentes à pintura da paisagem que seriam um verdadeiro guia para seu próprio trabalho artístico. Contudo, é justamente na sublime articulação entre inconsciente e consciente na percepção e apresentação da relação entre natureza e obra artística, a noção de gênio, que está sua maior admiração pelo autor ${ }^{42}$.

Olmsted procurou oportunidades para incorporar o princípio orgânico em sua atuação participando de modo inspirado desse processo que se revela na Natureza pelo transcorrer do tempo. Seus escritos testemunham esse contato com as matrizes teóricas e defendem uma prática que tem como horizonte revelar essa congruência entre homem e natureza através do projeto de espaços livres da cidade. A explicitação da verdade

você não terá conhecimento suficiente, ou a força suficiente para colher o ouro que se esconde em você. (...) o que você quer é inconscientemente e incidentalmente cultivar sua visão e a visão de sua mente e coração". OLMSTED, Collect Papers, Volume II, pp 341 e 342 , apud, FISHER, op cit, p 52.

40 E.D.Hirsh aponta que Wordsworth e Schelling, escrevendo contemporaneamente, desenvolvem e expressam metafísicas bastante semelhantes: cada um de forma independente desenvolve idêntica Weltanschaung, visão de mundo, embora , acusem os fatos, nunca tenham se conhecido. Cf. FISHER, op cit, $p 40$.

41 FISHER, op cit, p 58; SCHAMA, op cit, p 451.

42 A reutilização de um termo datado como gênius loci no 'Modern Painters', (V, cap 13), remete à cultura clássica, Virgílio, séc I, e foi reelaborado por comentadores do Renascimento como Polydore Vergil in 'De Inventoribus', 1499, (no qual discute sobre o gênio do lugar e dos edifícios), ou em Natale Conti em 'Mythologiae', (no qual argumenta sobre a origem do gênio como filho de Jove e da Terra). No tempo de Milton, 1670, em 'Paradise Lost', é comum falar-se de gênio como designando ainda o espírito ou deus do lugar. 0 estatuto de gênio vai sendo modificado do original virgiliano até o final do século XVIII. Quando o próprio Turner articular sobre ele falará antes sobre uma escondida e anônima vida da natureza que só é percebida com dificuldade, e que é passível de ser captada pelo artista. Ruskin, crítico da obra de Turner, reitera e desenvolve essa disposição. Cf. HUNT, op cit, p 221. 
das sementes e da natureza do lugar, suas propriedades vitais, são captadas e postas em jogo graças à arte do gênio.

O objeto de investigação a seguir diz respeito às teorias particularmente relacionadas à paisagem que tiveram domínio nesse período e como elas, associadas à filosofia, construíram um imaginário: duas idéias e seu trânsito, a intenção é desvelar os lugares pelo quais caminhavam os viajantes desse período, que qualidades de imagens eram objeto da experiência desses amadores da natureza.

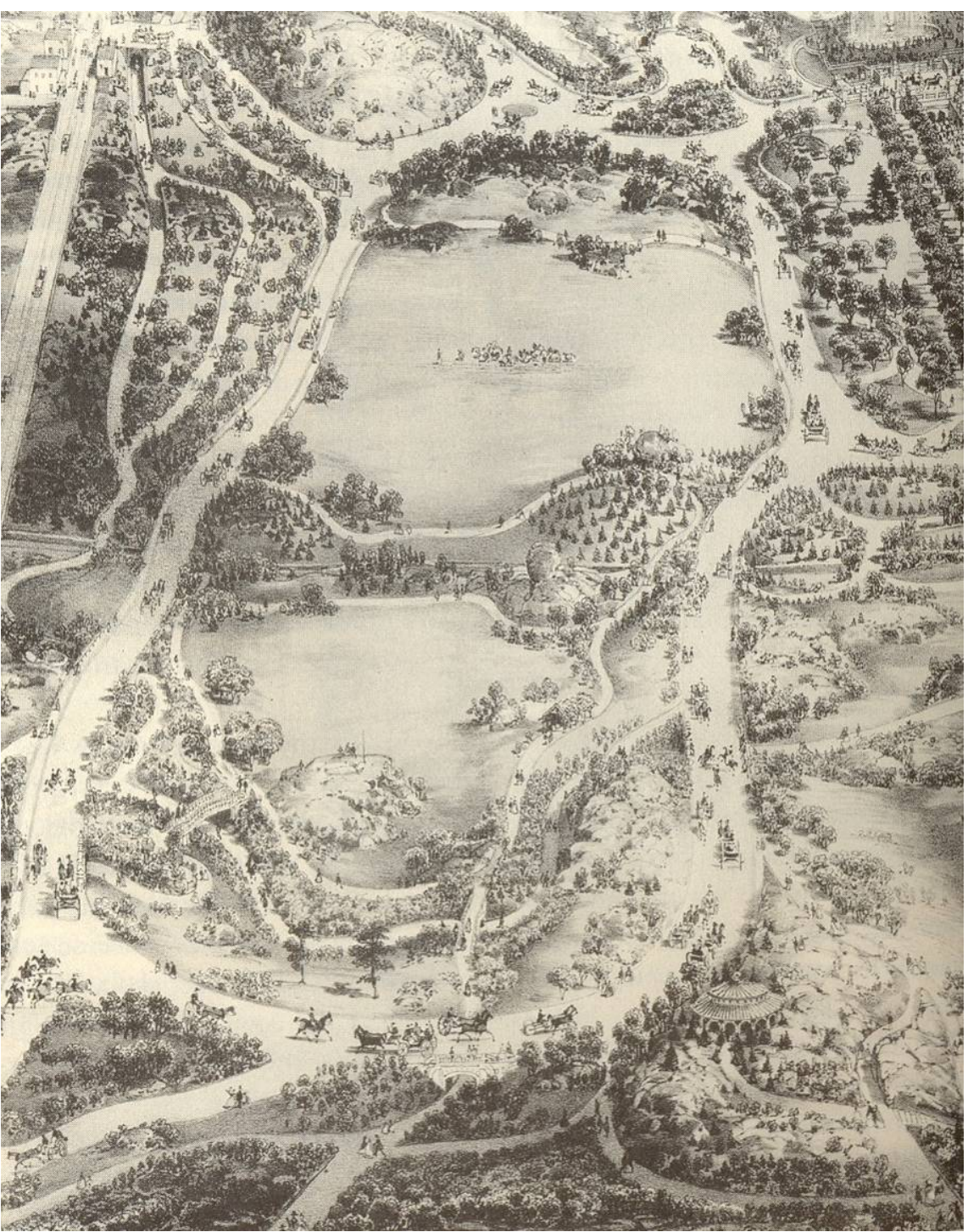

fig. 5 - Detalhe do Central Park de autoria de Frederick Law Olmsted e Calvert Vaux 


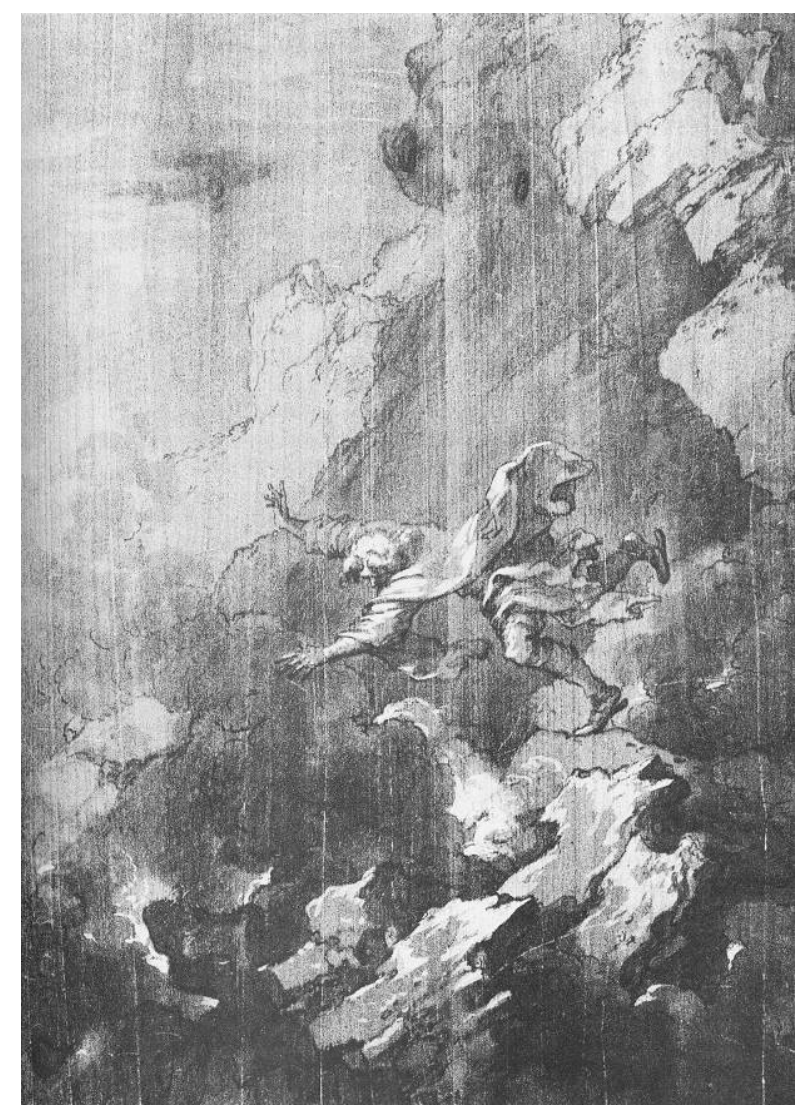

PINTURESCO E O SUBLIME 
Significados distintos de Natureza criam, para aqueles que pensam seu projeto a cada tempo, diferentes abordagens; o que significa imitar a Natureza e produzir uma Paisagem? Essas concepções, originalmente próprias dos pensadores e dos literatos, têm sua visualidade e tectônica desenvolvidas pela arte e arquitetura. A questão é precisar esse momento em que a percepção passa por uma importante mudança; o significado, antes relacionado a símbolos e alegorias, será liberto do domínio retórico e o preço dessa liberdade é um tempo no qual a incompletude, o inexato e o irregular ganham estatuto de arte.

A idéia de recuperação da Antigüidade e seus valores como a unidade entre homem e natureza é pressuposto programático para o Humanismo que funda o ciclo Moderno 1; a verdade natural que participará da base do naturalismo romântico do século XVIII passa por aproximações a primeira vista conflitantes. Esse capítulo procura compreender essas tentativas de estabelecimento de uma unidade a partir da figura da mímesis, bem como ensaia uma investigação acerca de sua possível sobrevivência num cenário Moderno.

No jardim do século XVI tudo que participa de sua variedade fala; nessa narrativa a retórica é o meio que assegura a ausência de monotonia, instrumento que permite a interpretação da natureza. 0 chamado jardim humanista do Renascimento resgata o Clássico através da leitura e tradução de textos; a narrativa da paisagem feita pelo grego está em segundo plano em relação ao primeiro que é o da ação humana ${ }^{2}$. 0 modelo não se baseia em imagens, o sentido que fundamenta toda a comunicação é garantido por determinadas percepções, os gêneros, subsumidos ao cânone da retórica e, nesse sentido, públicos: todo cidadão educado possuía as chaves para compreender o que se passava.

Marcadamente construído, esse jardim deveria possuir como atributos graça e amenidade, conquistados através de uma variedade controlada. Esse jardim transforma de modo radical parte do território, a imagem

1 SILVESTRI e ALIATA, op cit, pp 15 e 45. Essa sensibilidade remonta especialmente a Virgílio e seus escritos: As Bucólicas, escritas entre 42 a 37 aC. tratam da nostalgia do idílio Arcádico, quando pastores viviam em meio aos deuses. As Geórgicas, escritas entre 37 e 30 aC., ligam-se à destruição do mundo rural durante as guerras civís e vontade heróica de recuperação dos valores rurais.

2 HUNT, op cit, p120. 
resultante estabelece o contraponto entre a geometria das arquiteturas, inclua-se aí a topiaria da vegetação, e espaços em forma de bosque, portanto mais naturalizados ou pretensamente selvagens, do entorno; a água aparece sob controle em tanques e canais, mas seu movimento garante a aparente dissolução da forma: o modelo de beleza está ancorado na idéia de harmonia entre contrários. A questão da unidade entre partes remete ao todo, a simetria se pauta na idéia clássica de proporção e concordância entre partes. Esse modo de conceber o jardim perderá sua força a partir do desenvolvimento técnico-científico. Os mitos e alegorias que auxiliam na construção da variedade de significados irão se desvincular do pensamento nos períodos seguintes.

A retórica, que segue como meio de expressão e estabelecimento de uma linguagem até o século XVIII, tem na mímesis uma de suas figuras. A mímesis poderia ser traduzida num primeiro momento como imitação, o que nos levaria à idéia de cópia, contudo, essa significação é por demais confrontada quando se percebe o quanto mais elaborada é a apreensão desse copiar.

Na mímesis grega, a idéia de eleição é ponto de partida; seja a eleição de um especial que se emula, ou a escolha, entre vários, dos mais singulares elementos congraçados em uma composição ${ }^{3}$. Longino, século I, afirmaria ser a mímesis não a mera cópia, mas a exaltação arrebatada pelo exemplo; não a coisa, ou objeto em si, mas a força que a produz; uma estratégia que pretenderia tornar o artista apto a ter a visão, rivalizando desse modo a percepção do mestre 4 .

A abordagem Renascentista a partir de Alberti, explicitado no livro Da Pintura ${ }^{5}$, repercute a grega conforme atesta seu elogio à Zêuxis: pintor que sabiamente retira de cada corpo a singular beleza, e engenhosamente os arranja em perfeita composição - a natureza não deu a uma só pessoa, ou coisa, toda a beleza, a arte é então o apropriado meio de reuni-las.

\footnotetext{
3 “Narra-se em, antigo apólogo que Apeles e Praxíteles, mimetizando o natural aparente, valeram-se das gráceis formas de Frinéia - enaltecida como a mais famosa cortesã - como modelo para retratar Afrodite. Zêuxis, entretanto, quando foi incumbido de pintar a excelsa beleza de Helena, atinou outro procedimento: considerando não ser possível discriminar exemplar que conjugasse em um único corpo a completude das perfeições, selecionou, (...), de vários, suas excelências parciais, para congraçá-las em uma composição. AZEVEDO, op cit, p 16.

4 LONGINO, Pseudo Longino ou Dionísio. Do Sublime. São Paulo : Martins Fontes, 1996.

5 ALBERTI, Leon Battista. Da Pintura. Campinas : Unicamp, 1999, livro III, parágrafo 56; pp 143 e 144.
} 
A afirmação no século XVII, de que as disposições dos jardins em França seguiam de acordo com as Razões da Arte e da Natureza, leva ao fundamental postulado que impregna a época em que o tratado já mencionado de Boyceau foi escrito, comparecendo em suas pretensões penetrar a razão das coisas: que é o guia de todo bom trabalho, e necessidade para levá-lo ao fim. Para tanto se distinguem duas classes de razões; a que comanda a natureza da qual dependem as plantas: solos, climas, ar e águas, com a qual devemos operar em conjunto; e aquela razão, também pertencente à natureza, mas que nos capacita a julgar a tarefa, antes de executá-la, de modo que descendo à tarefa nós apenas trabalhamos reduzindo (sic) à grande escala as mesmas coisas que havíamos desenhado nas menores ${ }^{6}$.

Essa atitude engendra uma mudança na teoria da mímesis 7: a simetria e a variedade permanecem recomendáveis, como em Alberti, porque elas são princípios da natureza; no entanto, pretender alcançar a compreensão das leis naturais sem a Razão que dos homens participa e distingue, é permanecer ainda num anterior e ignorante estado. Afirmaria Boyceau, no final da introdução de seu terceiro volume: tanto quanto nossos primeiros tratados dependeram de um conhecimento da natureza e das razões da filosofia, eles também dependeram de nossas ciências de representação, a base e fundação de toda mecânica 8 .

Pintor, escultor e arquiteto serão assim capazes de forjar uma beleza superior que à comumente perceptível, e essa engenhosidade é fruto da razão, nesse sentido emulam o Criador e sua obra, ao mesmo tempo em que o exaltam uma vez que essa habilidade é fruto de sua generosidade 9 .

A apaixonada referência Clássica defendida por Johann Joachim Winkelmann, teórico de estética mais original do século XVIII 10, consagra nesse século a eleição da nobre simplicidade e da calma grandeza como o grande

6 BOYCEAU DE LA BARAUDIÉRE, Jacques. Treatise of Gardening According to the Reasons of Art and Nature, (1638). Apud LE DANTEC, op cit, $p$ 86.

7 LE DANTEC, op cit, p 89.

8 BOYCEAU apud LE DANTEC, op cit, p 90.

9 "Nas disputas entre eruditos no século XVIII é corrente o assentimento com o velho adágio que enuncia que a Arquitetura, como as demais artes, imita a Natureza. Inscrevendo-se numa retórica da elocução, a imitação não tem por objetivo a cópia simiesca do acontecer acidental da Natureza, ela tem por ofício o desvelamento de sua substancialidade: antes que macaquear a circunstâncias naturatas da criatura, cabe emular a constância naturante do Criador." AZEVEDO, 2007, p 31 
paradigma antigo a ser emulado. Esse ideal participaria ativamente de um novo padrão de gosto apresentado nesse período.

A revolução do gosto expressa pela historiografia em relação aos jardins na Inglaterra do século XVIII 11 poderia ser compreendida a partir da concepção de mímesis e sua singular relação entre natureza e artifício na paisagem. Até aproximadamente o primeiro terço do século, os jardins ainda transitam em chaves retóricas, ocorre que emular o Clássico implica, nesse momento, numa tradução dessa cultura, em especial da literatura atinente aos jardins.

A propriedade que Alexander Pope concebe em Twickenham a partir de 1718 apresenta disposições já presentes em seu Essay on criticism, (1711), no qual assevera acerca da subserviência francesa em relação aos antigos escritos: “...e Boileau ainda fiel a Horácio acata / Mas nós, bravos Bretões, leis estrangeiras desprezamos..." 12 .

melancolia, literatura e jardins

Os jardins da Inglaterra do século XVI, embora apresentem características da Renascença numa sucessão de partes variadas e aprazíveis, nenhum deles dispõe a mais decisiva qualidade do jardim do Renascimento: a concepção do lugar como totalidade. A interelação das partes dos jardins ingleses não é uma questão relevante, de modo que a crítica elaborada pelo autor Derek Clifford ${ }^{13}$, acerca da frivolidade desses lugares, do quanto eles ficavam dever à imaginação, só seria contornada quando do aparecimento da noção de unidade proveniente do jardim ideal de Bacon, (1597). Os Ensaios de Bacon demarcariam o início de uma idéia mais elaborada de jardim na Inglaterra.

\footnotetext{
10 Winkelmann não supõem que todos os antigos possuíssem essas características, mas elegendo o período no qual essas qualidades são representadas crê que os escultores que imortalizaram esses traços particulares, desvendam para nós o ideal de homem que se pode alcançar. BERLIN, op cit, pp 51 e 52.

11 GRIMAL, Pierre. Le Jardin Pittoresque, op cit, p 90. LE DANTEC, op cit, p128. CLIFFORD, op cit, p 124.

12 POPE, Alexander apud PEVSNER, Nikolaus. Estudios sobre Arte, Arquitectura y Diseño; del Manierismo al Romanticismo, era Victoriana y Siglo XX. Barcelona : Gustavo Gili, 1983, p 100.

13 CLIFFORD, op cit, pp 87 a 90. 0 autor afirma ser o tempo do reinado dos Tudors um período no qual o caráter dos jardins não parece ainda distinguir nenhuma qualidade nacional.
} 
O jardim descrito por Bacon não está totalmente emancipado, algumas qualidades medievas aparecem, como o mote do ver perpetuum, ou eterno verde, como se fosse possível que todos os meses reproduzissem o primaveril mês de maio; ou ainda, a idéia de que perfumes e fragrâncias acompanham e demarcam um passeio. É um jardim estabelecido de forma literária; tem a dimensão metafórica de ser um lugar do privilégio, embora sem qualquer qualidade extravagante, é o mais puro dos deleites humanos: o jardim de Bacon dispõe o contato com aqueles do jovem Plínio ${ }^{14}$, o lugar no qual se restabelece e refugia o espírito.

A descrição do lugar distingue três partes: a primeira equivalente a um parterre, ou terraço, uma ligação entre a construção e o jardim propriamente dito, a ocupação por um gramado se afasta do domínio francês e acumula as primeiras notas do que será tido como genuinamente inglês. A preocupação em fazer com que nas bordas do gramado estejam dispostos caminhos que proporcionam, graças ao treliçado, um ambiente confortável, tornam sua previsão mais próxima da proposta de uma experiência e mais afastada de domínios retóricos. 0 jardim descrito na seqüência contempla uma diversidade de aléias, o convite para prosseguir o passeio é apresentado parte a parte, não se desvelando o todo; não se tratam de meros corredores, mas de percursos que acessam pequenas clareiras de formas circulares que criam obstáculos à vista, algo que remete aos jardins conclusos medievais. A terceira parte diz respeito ao jardim selvagem: existe uma clara distinção entre o selvagem do medievo ${ }^{15}$ e o que apresenta Bacon; trata-se de uma imitação, conforme a natureza segundo seu relato: não há árvores, mas o aconselhamento de plantio de certas espécies, como a madressilva, as rosas amarelas e os morangos em abundância e sem ordenamento.

\footnotetext{
14 Plínio, o jovem, possuíra um jardim, o Laurentinum, no qual cultivava uma variedade de espécies de modo massivo, naturalizado, sem regularidades; era um lugar de descanso e refúgio da vida citadina, (distava aproximadamente $11 \mathrm{Km}$ de Roma), Plínio deixou dele descrições de um lugar aprazível e confortável, em apologias retratadas em cartas que foram traduzidas em 1728 para o inglês por Robert Castell, Ancient Villas, tornando-se modelo para toda uma geração. Cf. GRIMAL, op cit, p 34 e SCHAMA, op cit, pp 529 e 530.

15 “No século XII, por exemplo, em geral, os espetáculos naturais não têm interesse estético, talvez porque períodos de penúria venham lembrar periodicamente que a natureza não é uma mãe, mas uma inimiga contra a qual se deve sempre precaver". GRIMAL, Pierre. Les Jardin Romains. Paris : Presses Universitaires de France, 1967, p 5.
} 
Em 1621, Robert Burton publicaria sua análise sobre o que se costumou chamar a doença Elizabetana, The Anatomy of Melancholy ${ }^{16}$. 0 autor recomendava para a possivel cura, ou pelos menos para atenuar esse mal da melancolia, longas caminhadas por jardins e ambientes quer sejam os artificialmente selvagens, bem como os lugares naturais. John Evelyn 17, distinto horticulturista, escreve em 1643 sobre um pequeno jardim que constrói ainda na juventude, descrevendo-o como um lugar para despender suas horas melancólicas à sombra de árvores e junto ao silêncio. 0 mesmo Evelyn, convencido das benesses que os jardins poderiam produzir, especialmente relacionadas à moralidade e à espiritualidade, começa, em 1653, a reunir informações num grande trabalho que contemplaria os vários aspectos do assunto, inclusive sua história. Seria chamado Elysium Britanicum e, embora nunca tenha sido finalizado, seus escritos acumulam um enorme compêndio sobre jardim ${ }^{18 .}$

A ligação entre a melancolia e jardim remonta a tempos anteriores. 0 Renascimento promovera os quatro humores da natureza humana: colérico, fleumático, sanguíneo e melancólico. O filósofo humanista Marsílio Ficino popularizou a idéia, supostamente a partir de Aristóteles 19 , de que a melancolia estivesse sob o domínio de Saturno; os indivíduos melancólicos buscavam a solidão. 0 mesmo Ficino já aconselhava, contra os males melancólicos da alma, o verde da natureza e as caminhadas ao longo dos meandros dos rios; o desfrutar desses lugares teria efeitos de sutura na alma do sofredor.

O jardim por sua vez, também é percebido como o lugar que expressa a transitoriedade, seja porque repercute o clima e as estações, seja porque sua não manutenção delimita seu ocaso. Há também uma possível analogia elaborada entre o jardim e a brevidade da vida, sua inexorável mortalidade. Coffin em seus escritos procura mostrar como particularmente na Inglaterra dos inícios do século XVIII, algumas qualidades que participam da

16 A melancolia, entretanto, não apenas dominou o período Elizabetano e Stuart na Inglaterra, mas ocorre com igual proeminência durante o século XVIII, quando é também conhecida como spleen, sendo notada como uma particular doença inglesa na dissertação do dr George Cheyne de 1733. COFFIN, David. English Garden - Meditation and Memorial. Princenton (New Jersey): Princenton University Press, 1994, p 3.

17 John Evelyn será o autor de Silva, or a Discurse of Forest Trees, cuja primeira edição foi apresentada por ocasião da Restauração ao rei Charles II. A segunda edição já em 1669 é prova do imenso sucesso da obra, segundo Schama um casamento entre o prático e o fantástico, a precisão científica não prevalece sobre a poética, é mais que um livro de botânica. Evelyn pretende que ele "constitua parte do catecismo político de todo homem de Estado". SCHAMA, op cit, pp 159 e 160.

18 COFFIN, op cit, p 60 a 63.

19 KLINBASKY, R. PANOVSKY, E. and SAXL, F. Saturn and Melancholy. London 1964. apud COFFIN, nota 8, Introdução, op cit, p 225. 
construção do jardim denotam essas questões, quer seja na utilização do relógio de sol, a demarcar um tempo que até os finais do século XIII não era submetido à mecânica e que agora participa da vida dominando as necessidades e desejos ${ }^{20}$, quer seja na explicitação do gosto pela ruína; o tempo como um mote que se desdobra em diferentes reflexões e formas. Do mesmo modo, no transcorrer do século, a qualidade selvagem que aparece em Bacon será distinguida e elaborada como consolo da alma.

A proposta de estabelecimento de um nexo entre o apreço a esses lugares que expressam a transitoriedade, ruinosos e selvagens e um padrão de comportamento inglês, meditativo e menos acalorado, conjugado a esse pathos da personalidade bretã, a melancolia, constitui boa parte do cenário espiritual no qual se constrói o jardim inglês. O tema antigo da Natureza como lugar de consolação presente nas Éclogas de Horácio ou na Eneida de Virgilio, traduzidos e interpretados por diferentes pensadores, terá ainda, associado aos seus significados, a dimensão da liberdade.

\section{jardins, literatura e pintura: a natureza da alegoria à expressão}

Jardins como os da Condessa de Bedford, estabelecido em Hertfordshire desde meados do século XVII, são elogiados por Sir William Temple em sua obra Sobre os Jardins de Epicuro, (1685), no qual descreve o jardim mais belo e perfeito em todos os sentidos, ao menos como figura e disposição ${ }^{21}$; segundo Pevsner não é possivel ter claro se ele fora elaborado segundo padrão francês, com parterres e avenidas axiais, ou o holandês, com numerosos compartimentos como nos mostram as

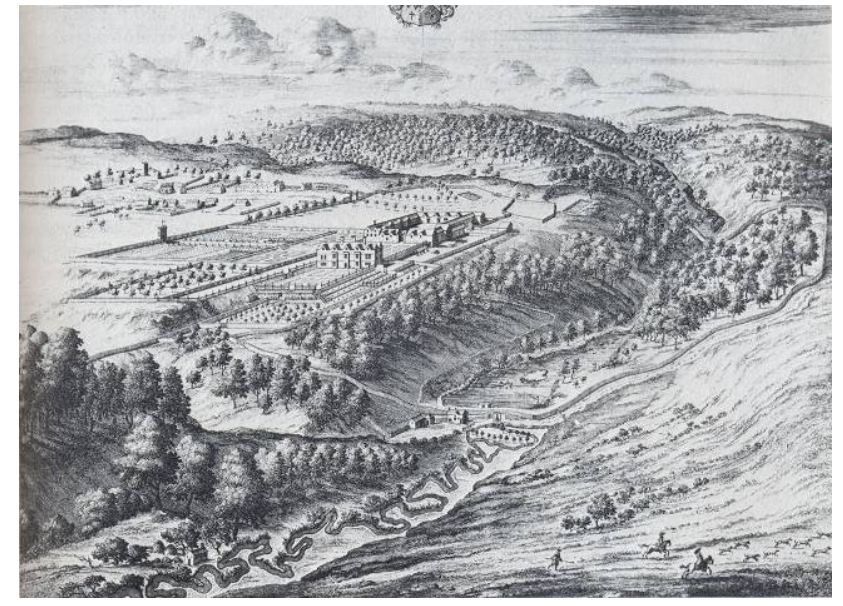

fig. 6 - propriedade de William Sandy, desenho de Jan Kip

20 "When I do count the clock that tells the time/ And see the brave day sunk in hideous night; SHAKESPEARE, William. Sonet XII, apud Coffin, $p 5$. 21 PEVSNER, Nikolaus. Estudios sobre Arte, Arquitectura y Diseño; del Manierismo al Romanticismo, era Victoriana y Siglo XX. Barcelona : Gustavo Gili, 1983, p 91e 92. 
gravuras de Kip. Para Clifford, entretanto, o Parque Moor, objeto de descrição de Temple, estava disposto sem desvios dentro das chaves holandesa e francesa da moda de então, tratando-se de um jardim bastante construído com terraços, fontes, estatuária, edificações e pavimentação; a afirmação de que o jardim segue a Natureza parece colocar Temple em consonância com o ideal de relação estabelecido entre Natureza e Razão, próprio da época. Contudo, o que se segue nesse escrito testemunha um autor cujo contato com as experiências possíveis nessa mesma época, especialmente em relação às viagens, fazem-no elogiar a irregularidade e a beleza proveniente de uma disposição aventurosa que capta o olhar e que resulta, enquanto conjunto, comovente 22 .

Ele afirmaria ainda que dificilmente poderia aconselhar qualquer dessas disposições de figura em jardins entre nós (ingleses) ${ }^{23}$, porém introduz um termo que posteriormente se torna bastante popular, pretensamente adaptado do chinês, sharawaggi, pelo qual se compreende as dessimetrias graciosas e pinturescas do jardim chinês 24 .

Esse trânsito entre simetria e assimetria, natureza e artifício nos inícios do século XVIII tem em seus primeiros movimentos as figuras de proprietários gentis homens como Charles Howard Carslile, Anthony Ashley Cooper, conde de Shaftesbury e o já mencionado poeta Alexander Pope; escritores incansáveis como Joseph Addison e Batty Langley; jardineiros com qualidades teatrais, botânicas e arquitetônicas como John Vanbrugh, Stephen Switzer e William Kent.

\footnotetext{
22 "Cabe que haja outras formas totalmente irregulares que possam, pelo que alcança meu saber, possuir mais beleza que qualquer das outras, mas as devem a certas disposições extraordinárias da natureza, ou a alguma grande competição de fantasia ou juízo no artifício, capazes de produzir várias partes em desacordo em um determinada figura, que, apesar de tudo, em conjunto, resulte muito agradável(...). Entre nós, a beleza da edificação e da plantação é adjudicada principalmente por certas proporções, simetrias, ou uniformidades, TEMPLE apud PEVSNER, op cit, p 94 e 95. Continua TEMPLE apud CLIFFORD, op cit, p 111: (...). Os chineses desdenham essa forma de plantar, (... ) seu maior poder de imaginação é empregado na criação de figuras, na beleza que deverá ser grande e atrair o olhar, mas sem nenhuma ordem, ou disposição de partes que seja comum ou facilmente observado. Ambos excertos de Upon the Garden of Epicurus.

23 CLIFFORD, op cit, p 128.

24 GRIMAL, op cit, p 93.
} 
Na Inglaterra do século XVIII, a forte admiração pela cultura clássica, legado acessado através dos textos originais ou especialmente vindos da Renascença ${ }^{25}$, passa por mais que uma simples tradução. Do contato entre essas fontes e o tido como autóctone inglês, natural ou artificial, desenha-se uma coexistência entre antigo e moderno através da fascinação pelo Gótico; sua recriação gradualmente tomará corpo no decorrer do século como forma original da cultura 26.

Alguns clássicos resistiam a estratégias de tradução, outros, como Plínio e Horácio eram aclimatados 27; um processo cultural que inclui a perspectiva de pensar esse período como o natural desenvolvimento de uma perspectiva que resgata o antigo, iniciada no Renascimento, e que segue na direção do que se pensava ser a apoteose dessa redescoberta na Inglaterra desse período.

Um exemplo dessa interpretação está na produção dos jardins e paisagem do castelo de Howard. Por volta da segunda década do século XVIII, seus idealizadores, o proprietário gentil homem Charles Howard Carslile e John Vanbrugh, escritor de peças teatrais, arquiteto e jardineiro, procuram equilibrar as chaves, Antiga e Moderna: Vanbrugh tinha entre seus livros o I Quattri Libri de Palladio, ao mesmo tempo em que era fervoroso defensor de edifícios Góticos quando julgava necessário utilizá-los ${ }^{28}$. A recusa do modelo francês e o anúncio da continuidade do jardim do Renascimento em seu território são revelados graças ao esforço de incorporação de técnicas desse período que sejam pertinentes às questões defendidas: a solução do bosque próximo atualiza o bosco, próprio dos jardins do século XVI, e estabelece o contato entre uma natureza pretensamente selvagem e o artifício da casa 29 .

\footnotetext{
${ }^{25}$ As primeiras edições de Virgílio se tornam disponíveis após a metade do século XV, o cenário pastoral se torna modelo a partir do qual as Villas eram então projetadas. 0 modelo Renascentista desse pastoral é apresentado também pelo exilado Jacopo Sannazaro em sua Arcádia, publicada em Veneza em 1519. Banido de Nápoles como Virgílio fora de Roma, Sannazaro recria o tema das Éclogas ampliando sua doçura, o que aqui não implica em um elogio, segundo SCHAMA, op cit, pp 530 e 531

26 CLIFFORD, op cit, p 125.

${ }^{27}$ Alexander Pope, gentil homem, poeta e jardineiro diletante foi intimado por um amigo em 1720 'a fazer Homero falar bom inglês'. In HUNT, op cit, $\mathrm{p} 11$.

28 HUNT, op cit, pp 24 a 27.

29 Horace Walpole, um dos críticos mais influentes do século XVII, convidava seus leitores a perderam-se na "grande criação cênica do Castelo de Howard, (...), nunca antes havia ficado tão gratamente surpreendido com a primeira visão de um lugar, (...). Em resumo, vi lugares gigantescos
} 
Enquanto os partidários Modernos acreditavam na idéia de progresso proveniente das experiências que cotejavam o cânone antigo ao imaginativo, os defensores dos Antigos firmavam a imutabilidade dessa representação e apenas por sua emulação é que a beleza poderia ser plenamente alcançada. Na argumentação dos Modernos, o Antigo fora, uma vez, o novo: a obra grega do período clássico produzida por um grego era, em seu tempo, o que de mais novo se poderia produzir; não havia porque desmerecer esse mesmo engenho humano desacreditando na sua capacidade de melhorar o já disposto, assim, o cânone era passível de receber modificações. A crítica se dirigia à crença na permanência do padrão clássico que terminava por engessar a Arte e especialmente a percepção. Eleger o Gótico, associado a um passado de glórias militares, como a possibilidade de afirmação do nacional, e transformá-lo numa questão corrente, era do mesmo modo essencial para esses homens que investiam na analogia entre os impérios, romano e inglês; ao mesmo tempo em que se sentiam iluminados por essa comparação, capazes de atualizar uma vez mais a idéia de arte e beleza. 0 êxito, que procuram lograr na disposição desse misto entre Clássico e Gótico, pretenderia apresentar a Inglaterra como o grande árbitro final na velha batalha entre Antigos e Modernos ${ }^{30}$.

Anthony Ashley Cooper, conde de Shaftesbury, escreve The Moralist em 1711, um livro sob a forma de diálogos platônicos no qual declara a paixão pelas coisas de índole natural, nas quais nem a arte, nem o capricho do homem tenham desviado da origem genuína. O ponto de vista corrente até então fora de matriz aristotélica e expressava a crença num estado original de perfeição; a diferença é que, longe desse estado ter sido modificado por acidentes, e caber ao homem restaurar a perfeição da natureza corrigindo-a pelo artifício, o estado natural nesse período inclui o homem; ele, partícipe dessa natureza busca não corrigi-la, mas convergir, buscar e encontrar a concordância que fora espoliada pelo excessivo artifício.

antes, mas nunca um tão sublime”. WALPOLE, apud STEENBERGEN, Clemens/ REH, Wouter. Colaboração de SMIENK, Gerrit. Arquitectura y Paysaje - La Proyectación de los Grandes Jardines Europeus. Barcelona : Gustavo Gili, p 16.

30 AZEVEDO, op cit, pp 10 e 11:"Por um lado, ponderam os partidários dos antigos que o cânone da Arte, a verdade - resultante de escrupuloso escrutínio do substancial na Natureza - , sendo uma e mesma, não pode se estear na incerteza de experiências individuais e subjetivas, e tampouco pode ser susceptível à volubilidade de alguma invenção imaginativa; (...). Por outro lado, argumentam os modernos que, mesmo para o reto e sensato Entendimento, a mediação dos sentidos e a ação dos sentimentos não podem ser menoscabadas, (...) com o aprimoramento das ciências, dos conhecimentos e das habilidades, as técnicas e ofícios são passíveis de apuramento - , às Artes, à Arquitetura - (...) também será facultado o melhoramento". 
A idéia do gênio do lugar, genius loci virgiliano comparece como referência antiga nos escritos de Shaftesbury, um divino princípio que se revela pela e na natureza, ele auxilia no desvendar da visão de unidade: "a Natureza e o genius loci são apenas nossa ajuda terrestre para obter ao menos uma leve e distante visão do Gênio soberano e da primeira beleza" 31.

Uma série de ensaios é publicada no periódico The Spectator por Joseph Addison, (1672-1719), entre junho e julho de 1712. Esses ensaios, conhecidos como Os prazeres da imaginação, são de especial relevância porque trabalham noções estéticas que serão reapresentadas durante todo o século XVIII, participando da formação do gosto de toda uma geração 32; argumentando que a natureza é melhor que a arte, a rudeza melhor que a nitidez, a árvore em seu livre crescimento, melhor que a podada, enaltece uma natureza em detrimento do artifício, e a associa à promoção de uma razão e virtudes inglesas. Sua estratégia desafia a moda de então e sua fala termina por auxiliar na criação da brecha pela qual se assistirá a derrocada dos projetos afeitos à regularidade, isso se dá em consonância com quedas ocorridas em outras instâncias 33 .

Pierre Grimal apresenta os primeiros jardins desse novo estilo, entre 1720 e 1730, como direta e conscientemente inspirados nos motivos orientais ${ }^{34}$, afirma ainda que possivelmente essa singular estética não imite o jardim chinês senão em seu aspecto exterior, sem a compreensão de seu espírito. Porém, a questão que parece estar por trás dos elogios e vitupérios de Addison é a complexa construção de uma nova relação entre arte e natureza: a imagem que o Oriente apresenta, preenche a expectativa dessa liberdade que se desenha no espírito.

\footnotetext{
31 COOPER apud PEVSNER, op cit, p 96.

32“A descrição que Addison dá à Imaginação (a faculdade de apresentar as imagens ao espírito) é uma herança antiga e medieval na Renascença; as categorias que ele propõe: O Grande, o Novo e o Belo - têm quaisquer antecedentes, mas são importantes para a posteridade, e contribuem para fixar os conceitos do século XVIII; a distinção entre o Grande e o Belo foram reapresentadas por Burke sob a forma de Sublime e Belo; o Novo se transforma nos estudos sobre o papel estético da surpresa. MARTINET, Marie-Madeleine. Art et Nature en Grande-Bretagne. De l'harmonie classique au pittoresque du premier romantisme, 17e - 18e siècles. Paris : Aubier-Montaigne, $1980, \mathrm{p} 74$.

33 “Todas as forças para uma fundamental mudança estão agora dispostas na Inglaterra contra o jardim arquitetônico. Os filósofos haviam descoberto a beleza do mundo anterior à Queda. Os economistas apontavam que a organização da vegetação era excessivamente cara. Os jardineiros achavam bastante difícil introduzir novidades dentro das velhas convenções. O olhar do mundo da moda havia sido familiarizado com os padrões assimétricos da porcelana chinesa, os laqueados, as sedas. A monarquia despótica estava morta, o despotismo clerical estava sendo rejeitado, a mente...e o paladar...estavam livres para explorar, e o mundo estava pleno de surpresas e suspense." CLIFFORD, op cit, p 129.

34 GRIMAL, op cit, p 95.
} 
Alexander Pope defende que a natureza deve ser estudada; seu jardim em Twickenham, construído entre 17181725 é um comentário cultural no qual transparece uma natureza metodizada 35. Grimal afirmaria ser um curioso paradoxo esse que une Pope e Boileau. A Natureza como fonte, como medida serve para justificar na Inglaterra um estilo em contraste absoluto com o estilo francês ${ }^{36}$. A percepção desse paradoxo, tanto quanto a acusação de uma pretensa acomodação na arte dos jardins em França parecem se revelar à luz da compreensão do que venha a ser Natureza nessas distintas culturas.

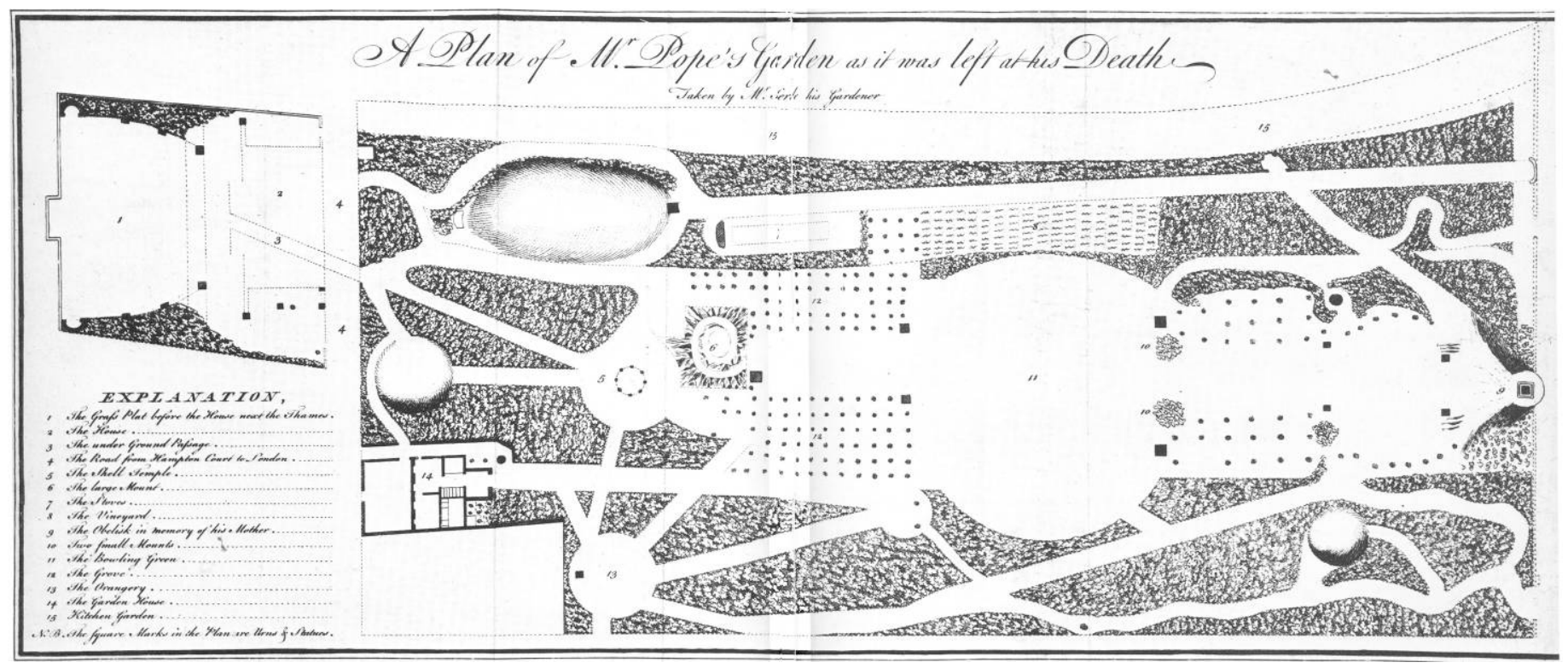

fig. 7 - Twickenham, propriedade de Alexander Pope

\footnotetext{
35 Alexander Pope, Essay on criticism (1711), apud PEVSNER, op cit, p 103: Primeiro siga a Natureza, e teu padrão de julgamento/ pela sua norma justa, que ainda é a mesma... / Infalível Natureza...: deve conferir a tudo/ de imediato a fonte, e fim, prova final da arte / Arte daquela base que provê a cada um suprimentos adequados/Trabalhos preside sem exibição e sem pompa./ Aquelas antigas leis, descobertas, não planejadas/ São ainda Natureza, mas Natureza metodizada./ A Natureza, como a liberdade, é apenas governada/ Pelas mesmas leis que ela mesma estabeleceu primeiramente".

36"Não parece que a escola clássica francesa tenha sido consciente da contradição de uma arte que, na literatura, pregava o retorno à Natureza e ao Verdadeiro, e, para os jardins se acomodava confortavelmente no artifício e na geometria". GRIMAL, op cit, p 94.
} 
A razão e a natureza em Pope são par que expressa congruência e não correção; o que a princípio parece remeter ao século XVII, significa de fato uma mudança no matiz dessa razão que não se faz mais francamente mecânica 37. A maturidade de Pope expressa, em seu Essay on Man (1733), não um universo matemático, mas amoroso, não o amor sujeito à hybris apaixonada, mas sim na direção da construção de uma paisagem que revela essa percepção, sob especial e tensa harmonia entre natureza e artifício.

Seu jardim no tempo desse ensaio já está configurado e testemunha certos resultados bizarros, ou simplesmente estranhos se vistos isoladamente ${ }^{38}$, mas imensos se visualizados como metáfora da condição humana; a descrição da gruta em sua multiplicidade de materiais e disposição fazia com que visitantes do local narrassem efeitos visuais que a torrente dessas imagens provocava 39 - são significados que essa verdadeira máquina meditativa, o grotesco mundo submerso de Pope, é capaz de suscitar: ela se realiza através de emblemáticas representações, portanto uma de suas faces ainda mira o século XVII, ambientada na edição inglesa de Cesare Ripa, 1709, Iconologia ou Emblemas Morais, dedicada ao modo de representar as virtudes, paixões e vícios; mas a outra face visualiza um arranjo que leva a uma qualidade expressiva, por vezes selvagem e aterrorizante ${ }^{40}$.

Outros objetos e produções cumprirão também a vez de significar nesses jardins; eles apresentam uma irregularidade que passa a ser o tom desse gosto que se constrói ligado à metáfora ${ }^{41}$. 0 artifício tem uma vez mais seu papel, imprimindo através dessa outra figura de linguagem, que implica numa transferência, nova e ampliada significação à original.

\footnotetext{
37 “Look round our world, behold the chain of love / Combining all below and all above". POPE apud AZEVEDO, op cit, p 4. [Observa em torno nosso mundo, contempla a corrente de amor/ combinando tudo acima e tudo abaixo].

38 CLIFFORD, op cit, p 134.

39Próximo de Richmond, à margem do Tâmisa, Alexander Pope vai projetar, a partir de 1718, seu célebre jardim de Twickenham. Como o parque está separado da casa e do rio por uma longa estrada, Pope imagina, de modo a estabelecer uma comunicação, um longo túnel imitando os cryptoportiques, [passagens repletas de símbolos], romanos. Ali ele realiza um sacrifício à antiga tradição da "galeria de encantamentos", amontoado de amostras de minerais preciosos e raros. Uma estrela de vidro, ao centro, refletindo a luz de uma lâmpada de alabastro, (...). Os criptopórticos de Pope, a um só tempo gabinete de história natural e instrumento psíquico retorna ao que conformava o século anterior, o velho motivo do jardim conhecido como compêndio do Universo. GRIMAL, op cit, p 99.

40 HUNT, op cit, pp 75 e 76.

41 Diz Aristóteles: a Metáfora consiste em dar a uma coisa o nome que pertence a outra, cf ABBAGNANO, verbete Metáfora.
} 
A ruína nesse sentido é decoro, ornamentação de uma paisagem, mas ao mesmo tempo é expressão de uma transitoriedade, do efêmero. John Vanbrugh é o primeiro a atentar para suas qualidades estéticas e significantes em sua argumentação acerca da manutenção dos restos de uma casa senhorial do medievo, nas cercanias da nova mansão em Blenheim. Em retórica eloqüente, dirige carta à duquesa em 1709 assinalando que sua manutenção deixaria um dos mais agradáveis objetos que o melhor pintor de paisagem pudesse inventar, contudo a duquesa ordena que se limpem os terrenos.

A mudança no padrão de gosto, até a apaixonada frase de William Gilpin em 1772: a ruína é uma coisa sagrada, percorre o século em plena elaboração. Seu elogio, e mesmo necessidade, são expressos em ilustrações, por exemplo, no Principles of Gardening, 1728, de Batty Langley, que recomendam, na ausência dessas no território, sua representação sob a forma de pintura ou construção, realizadas em tijolos e recobertas com outro material maleável, moldável à guisa de pedra. A primeira ruína construída em 1733 aparece na propriedade de um amigo de Pope, Lord Barthust 42.0 ambiente no qual Gilpin desenvolverá sua paixão está sendo construído na primeira metade do século XVIII 43.

Ao que parece, Stephen Switzer é o único jardineiro que tentaria a exposição de uma nova doutrina nesse período, e a elabora a partir do Utile Dulci, uma judiciosa mistura e incorporação dos prazeres do campo à questão econômica 44: existe a intenção de melhoria na paisagem, como a incorporação de trabalhos em água, estatuária e caminhos sombreados, bem como uma disposição de libertar a vista para todo a campo adjacente, francamente associada à diminuição dos custos de manutenção da propriedade; asseverava ele, em primeiro lugar, que escrevia de modo a introduzir uma maneira mais econômica de jardinagem, para responder a demandas daqueles que estavam assustados com os custos da maneira corrente.

\footnotetext{
42 COFFIN, op cit, pp 30 a 37.

43 A reflexão realizada por Pevsner acerca da estranheza dos lugares e da aparente confusão teórica do período liga-se ao fato dos homens que se ocuparam da arte dos jardins nessa época serem educados na atmosfera do rococó, in PEVSNER, op cit, p 117. Essa perspectiva é rechaçada críticamente pelos Le Dantec em sua raiz: “Esse termo, (rococó), um tanto ridículo sugere um tipo de exaustão que afeta o 'grande estilo', a degeneração no maneirismo pela qual a ornamentação era o objetivo e a afetação o principal registro.(...) A teoria é certamente prática, mas grosseira, tanto para Luis XV quanto para a coleção de trabalhos memoráveis em todos os sentidos, iniciando-se com aqueles excepcionais pintores aos quais se pode dar o crédito de terem alçado a paisagem na direção do espaço da sensibilidade." LE DANTEC, op cit, p 127. ${ }_{44}$ SWITZER apud CLIFFORD, op cit, pp 126 e 133.
} 
Switzer era um homem de alguma formação e mente literária; publicaria o livro The Nobleman, Gentleman and Gardener's Recreation em 1715, que foi ampliado e reeditado em 1718 e novamente em 1742, agora com o nome Ichonographia Rustica. Ele procedia, segundo suas próprias palavras, num tipo de jardinagem extensiva ainda não muito comum, oposta ao que os franceses chamam Le Grand Manier, com sua topiária e decorações.

William Kent conheceria seu principal patrono e grande admirador, Lord Burlington, em Roma quando em viagem para estudar pintura. O elogio a esse arquiteto, cuja frase mais lembrada afirma que a Natureza abomina a linha reta ${ }^{45}$, foi inaugurado na historiografia por um contemporâneo de século, Horace Walpole, (1717-1797), que afirmaria ser Kent o responsável pela a invenção do novo estilo: Kent parecia possuir o inigualável mérito de lograr o que seria estabelecido como pinturesco na paisagem; a mistura que relaciona os

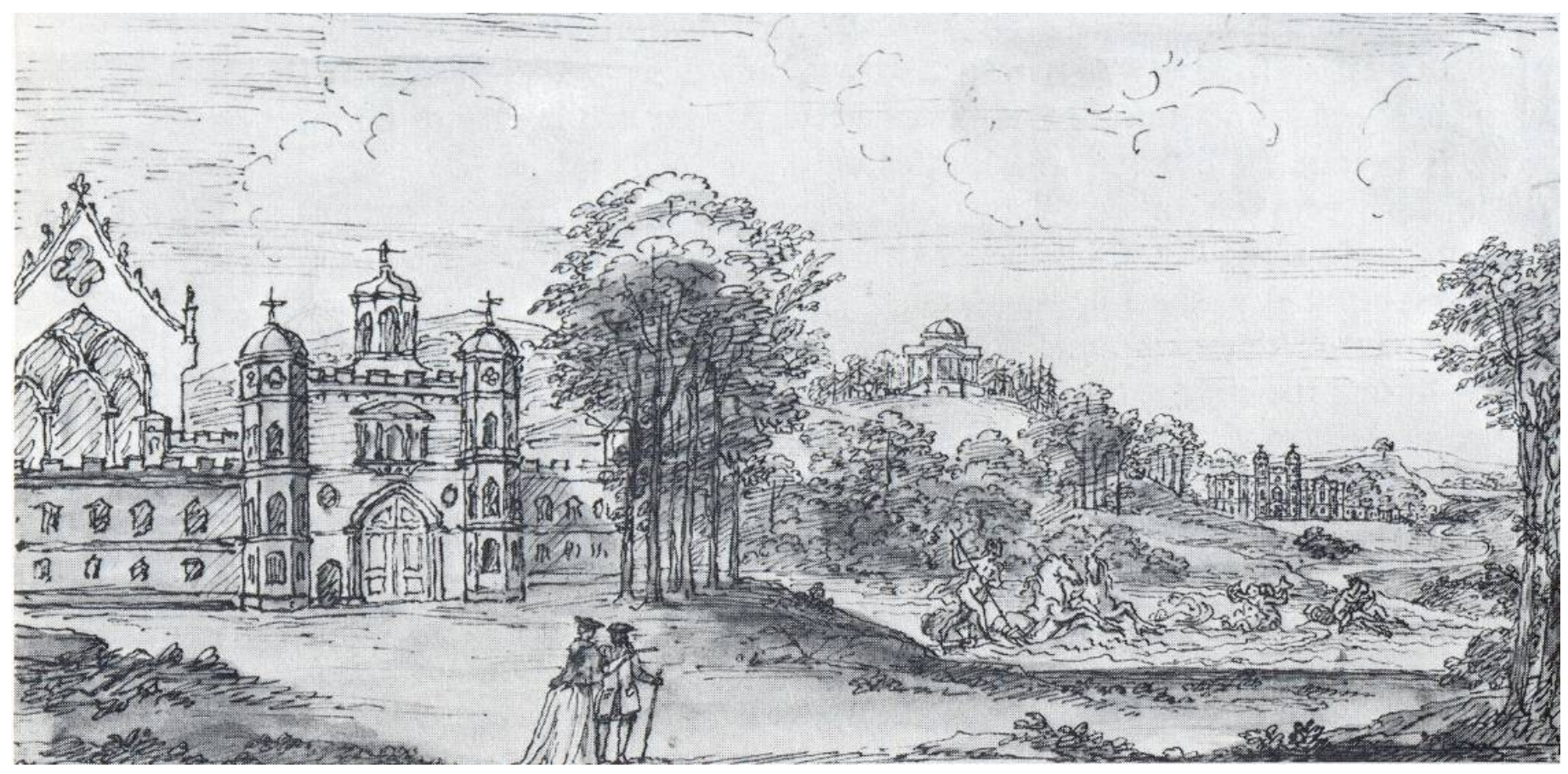

fig. 8 - Desenho de William Kent

45 CLIFFORD, op cit, p 135. 
elementos arquitetônicos e o lugar em que os dispõe, sua obra mestra em Stowe coleciona troféus de todos os tempos ${ }^{46}$. Evidentemente fundamentado nas descrições antigas sobre as qualidades da Villa Adriana em Tívoli, o trunfo de Kent é a ambientação pictórica que fora capaz de produzir associando natureza e artifício.

A grande conquista que relaciona técnicas e novas compreensões é a transformação do jardim em paisagem, essa qualidade de continuidade na percepção de uma natureza sem interrupções é obtida graças ao aperfeiçoamento de uma estratégia inaugurada em território inglês por Charles Bridgemann, o haha, ou cercamento em valas 47 .

O desenvolvimento do jardim de paisagem, ou paisagístico estabelece forte conexão entre as chamadas artes irmãs atestando, uma vez mais, o nexo entre dimensões artísticas; afirmaria Walpole que Poesia, Pintura e Jardinagem, ou Ciência do Jardim, serão chamadas pelos homens de gosto as três irmãs, ou as Três Novas Graças, que vestem e adornam a Natureza 48.

As dimensões das relações entre as artes irmãs desvendam imprecisões quando observadas na proximidade. Walpole, autor do History of the Modern Taste in Gardening, 1771, deixaria em seus escritos sua opinião: quando um francês lê acerca dos jardins do éden, eu não duvido que ele conclua que é algo próximo de Versailles com cantos tosquiados e trabalhos em treliças ${ }^{49}$; contudo em França o gosto também passa por uma revolução.

A percepção de que o espírito inglês diferia profundamente do francês e que isso era referendado no gosto e concretizado na paisagem é abalado quando se observa os planos para os domínios do jardim de Versailles de 1820. Embora seja verdade que Shaftesbury tenha visitado a Itália em finais do século XVII e, ao encontrar as

46“William Kent, maior arquiteto de jardins da primeira metade do século, soube ampliar a estética sharawaggi e integrar nas composições mais vastas onde se exerceu, uma vez mais, a influência italiana (...)Também o Barroco italiano faz uma aparição inesperada nesse estilo que se acreditaria, no entender dos teóricos, mais respeitoso da verdadeira Natureza." GRIMAL, op cit, pp 99 e 100.

47 PEVSNER, op cit, pp114 e 115.

48 WALPOLE apud HUNT, op cit, p 75.

49 SCHAMA, op cit, 538. 
pinturas de Claude e Poussin, compreendesse seu contraponto à paisagem Versailles 50, a brecha para a afirmação de uma natureza liberta, a mudança pela qual passa a época, inclui também os jardins franceses.

Temple, Pope, Walpole e Whately 51 estarão sendo traduzidos e devorados na França de meados do século XVIII 52. Muitos trabalhos falam da importância da descoberta pelos ingleses do jardim chinês. A sinomania traduz-se por uma paixão avassaladora pela irregularidade, bem como por um novo suprimento de decoros vindos sob a forma de pagodes e pavilhões. O papel desempenhado pelo pintor e desenhador Hubert Robert no desenvolvimento dos jardins do século XVIII na França é de especial importância; sua representação pictórica engendra o apreço pela ruína e pedras recobertas pelo musgo e hera, possivelmente alentados em sua estada em Itália. As reformas de Versailles, sob os auspícios de Maria Antonieta são obras grandiosas e envolvem o jardim e palácio, sendo também pintadas pelo próprio Hubert: a destruição é representada como captura desse tempo de transformações do gosto e

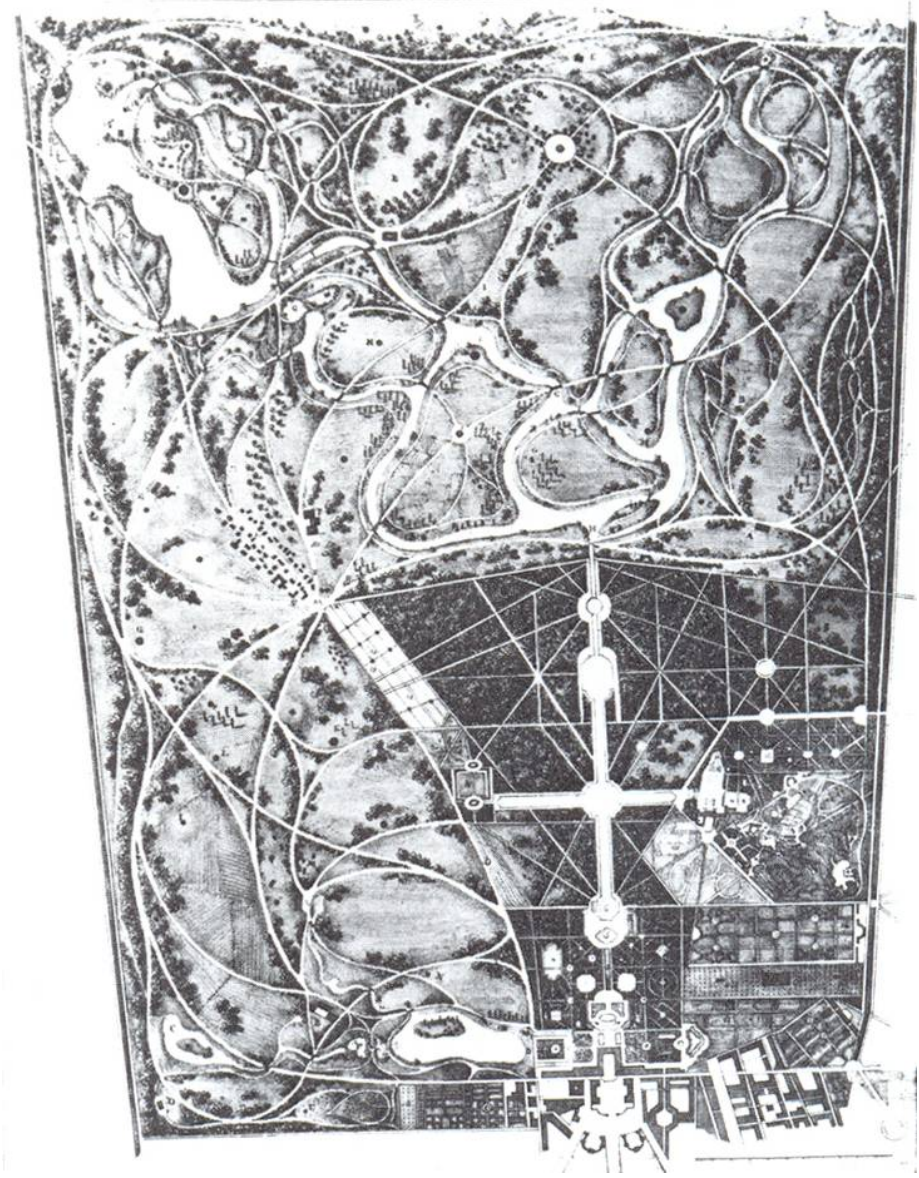

fig. 9 - Projeto para os domínios de Versailles

50 CLIFFORD, op cit, p 128.

51 “Escrito em 1765, cinco anos antes da publicação em Londres e Dublin, 'Observations on Modern Gardening' foi traduzido para o francês no mesmo ano em que chegava à sua 15a. edição inglesa, por volta de 1793. Whately, (às vezes )Whateley, propôs para a arte da jardinagem paisagística o que tinha sido frequentemente disposto para a pintura, a saber, um tratado com seus objetivos , métodos e realizações." In The Genius of the Place. The english Landscape Garden 1620-1820. Edited by John Dixon Hunt and Peter Willis. The MIT Press : Cambridge/London, 2000, (1988).

52 LE DANTEC, op cit, p 124. 
percepção do mundo; suas representações mostram parterres destruídas e árvores com a forma de caixas arrancadas, em meio a isso rei e rainha caminham com sua gente, ambientados na ruína 53.

Pintura e poesia dialogam na paisagem dessa época. Thomas Whately ressalta o quão vital se tornou o expressar para além da simples experiência, o provocar da visão para além do que se vê: Outra espécie de característica aparece da direta imitação; quando uma cena, ou um objeto, que está sendo celebrado na descrição, ou é familiar na idéia, é representado no jardim. Ruínas artificiais, lagos e rios participam dessa denominação; a atmosfera de um lugar expresso à distância, e cenas calculadamente provocativas da idéia de elegância Arcádica, ou simplicidade rural, (...). Mas a arte do jardim aspira mais que a simples imitação: ela é capaz de criar qualidades originais, e dar expressão a diversas cenas de modo superior à mera alusão. Certas propriedades, e certas disposições dos objetos da natureza são adaptadas para exercer particulares idéias e sensações 54 .

Não se trata mais da retórica como fora nos séculos anteriores, entretanto, certas figuras resistem e de fato fundamentam essa visão, mas subsistem ampliadas em sua complexidade nessa construção que se elabora entre homem e natureza. 0 furor hortensis, apontado por Gusdorf, afirma não se tratar apenas de uma paixão pelo jardim essa que se revela no século XVIII sob a forma de comentários, poesia, pintura e lugares mesmos. É antes uma determinação de unir o mundo sob uma forma, como um quebra-cabeças que une sensações, emoções, iniciação filosófica, didática social e estética, botânica, litologia, citações de grandes homens, testemunhos históricos e geográficos "fabricados"55. Essa expectativa estabelece uma paisagem que se apresenta como o microcosmo do universo, numa proposta muito além da aparente simplicidade arcádica 56.

\footnotetext{
53 LE DANTEC, op cit, pp 125 a 128.

54 WHATELY, Thomas. Observations on Modern Gardening, 1770. Apud HUNT and WILLIS, op cit, pp 305 e 306.

55 GUSDORF apud LE DANTEC, op cit, p 131.

56 De modo a descrever a redescoberta da natureza no século XVIII, os termos ingenuidade e simplicidade são comumente usados. De fato, as maiores vozes do período, a começar com Rousseau, continuamente pranteiam as virtudes dessas duas qualidades. Mas nada poderia ser mais falacioso que deduzir disso a rejeição do artifício, ilusão e deliberada complexidade, para o benefício de um retorno a um estado original sem alguma preparação envolvendo a inteligência humana. LE DANTEC, op cit, p 130.
} 
Embora a tese de Grimal seja referenciada pela cronologia, em finais do século XVIII, toda uma geração será tocada por Jean-Jacques Rousseau e sua filosofia fundada na redescoberta de uma Natureza: conforme a Nouvelle Héloïse amar o jardim clássico (francês) é, para Rousseau, não apenas prova de mau gosto, mas testemunho de uma alma depravada 57.

Tem-se, portanto, um quadro de relações que associam razões econômicas e alterações perceptivas, ações de afirmação cultural e identitárias; em meados do século o desenvolvimento da configuração do que se chamará pinturesco e a nova roupagem que será estabelecida para a antiga figura do sublime, a partir do escrito de autoria de Edmund Burke: Uma Investigação Crítica acerca da Origem de nossas Idéias de Sublime e de Belo, (1757), constituirão, ao lado do Belo, as principais chaves estéticas em valência no período posterior.

\section{rudeza e confusão: um novo status para a paisagem}

Simon Schama inicia a quarta parte de seu livro Landscape and Memory apresentando a Arcádia em sua dupla face. De um lado a conhecida, bucólica e construída a partir de Virgílio no primeiro século, suave e luminosa; das Arcádias, a dominante: é ela que os jardineiros têm em mente quando constroem o Elysium no castelo de Howard, ou o autor Rousseau emula, quando estabelece o Elysée, nome do jardim de Julie. Contudo, há uma outra face, uma Arcádia áspera e soturna, na qual ao invés do deleite lânguido se estabelece o primitivo pânico.

Essa outra Arcádia nunca de fato fora apagada, apenas banida para além dos muros, treliças e cercas, mas quando rudeza e confusão se tornam termos de apreciação em paisagens, é evidente que a velha Arcádia está se tornando uma vez mais visível 58.

\footnotetext{
57 A elaboração de Grimal não tributa à filosofia de Rousseau responsabilidade na transformação do jardim em seus princípios, sua reflexão se volta muito mais para a abertura do mundo e o contato com a China e seus jardins irregulares. Rigoroso em relação à datação observa que o romance de Rousseau, no qual descrevendo os jardins de Julie acrescenta a eles valor moral e mesmo religioso, é escrito apenas em 1760: "os primeiros jardins pinturescos precederão aos textos literários escritos em sua glória." GRIMAL, op cit, p 93.

58 SCHAMA, op cit, pp 537 e 538.
} 
Os ensaios de Joseph Addison no The Spectator, 1712, revelaram não só a defesa de um certo grau de naturalidade para a arte dos jardins ${ }^{59}$, mas também, e especialmente, uma particular percepção estética a partir da a descoberta de um novo prazer, quando o Acaso parece possuir um Efeito de Desenho, que está nas origens desse desenvolvimento do que veio a ser chamado de teoria estética da composição: o crescente interesse pelo irregular ritmo da natureza.

Algumas qualidades dessa sociedade conspiram para esse crescimento: a propalada afeição por parte do homem inglês em palmilhar seu país é fruto da associação entre o apreço inglês pelo exercício físico 60 à curiosidade de descobrir e revelar paisagens singulares. Talvez a informação mais transformadora em termos culturais tenha sido o fato do viajar ter se tornado uma prática desejada e instruída: o território inglês e sua paisagem são agora objetos de visitação e construção cultural. Essa questão causava um afastamento da referência puramente clássica e mergulhava a percepção em um universo de altas montanhas e paisagens selvagens cuja rudeza se fazia de difícil transição para o vocabulário das linguagens ditas neoclássicas.

Imaginar e procurar são essencialmente atividades pinturescas que o XVIII formalizou para os viajantes. As cenas podiam ser colecionadas pelos turistas, que davam a elas outro significado que seus habitantes locais. Um olhar estrangeiro, por vezes apenas de outra região do mesmo país, vai sendo treinado para viagens ainda maiores; quando o Império inglês se instalar ampliando o cenário para o mundo, essa prática observadora fará parte do imaginário de uma época.

\footnotetext{
59 “Determinar o que realmente significara esse natural iniciou uma discussão que não chegou a nenhuma conclusão fácil. Em termos breves, a controvérsia tinha como ponto central a questão da possibilidade do artifício humano ser alinhado a outros aspectos naturais, ou suas leis invisiveis. O Pinturesco tenta ocupar uma posição deslocada que mistura artifícios óbvios e regulares com o irregular, menos aparentado com o artifício derivado da natureza. O aspecto da Natureza era uma referência, mas o desenhador (designer) mantinha a liberdade de arranjar as árvores, água e pedras de acordo com uma composição ideal.” ROBINSON, Sidney, K. Inquiry into the picturesque. University of Chicago Press: Chicago \& London, 1991.
}

60 CLIFFORD, op cit, p 124. 
Reconfigurar a união entre homem e natureza implica numa nova compreensão do sentido de mímesis. 0 que antes era mediado pela retórica deve ser substituído pelo olhar sem filtros do poeta inspirado. Uma nova Arcádia se esboça, a mímesis não é mais das aparências, mas do que subjaz, do que estando oculto espera ser revelado; é na paisagem que se estabelecerá essa singular união.

A determinação de unir o mundo sob uma forma encontra na natureza a fonte para a elaboração das peças daquele quebra-cabeças ${ }^{61}$, trata-se de um desvelar que não é mais geométrico, ou matemático, mas descritivo, fortemente alicerçado na acumulação das experiências; a representação nesse contexto abandona as construções realizadas a partir de regras e passa para o domínio das sensibilidades privadas; deixa a pretensa universalidade de tradução da retórica e se lança na direção do prazer vagamente definido como caráter. A resposta se esboça a partir de categorias intangíveis, interiores e individuais.

Parte dessa liberdade, porém, virá da ignorância. John Dixon Hunt 62 afirma que a alteração da classe dominante que se vê paulatinamente substituída por outra, predominantemente burguesa, constitui um fator de peso nessa mudança de percepção. Enquanto a primeira era constituída por nobres homens que viam a leitura dos Clássicos e a Grand Tour, a grande viagem à Itália, como parte vital de sua educação; a segunda ligava-se muito mais à arte e cultura holandesas bem como a sua temática despretensiosa, ao invés dos modelos antigos referenciados pelas imagens de Claude e Poussin. Esse hiato cresce no decorrer do século e vai tornar a observação daquelas pinturas mera observação de uma paisagem, sem maiores referências. É a essa eliminação das qualidades de significação, à decadência das questões retóricas, que Hunt tributa a possibilidade de aparecimento em meados do século XVIII do auto denominado Capability Brown.

61“Esse programa, naturalistico e enciclopédico quase a despeito de si mesmo, implica e designa precisamente o lugar no qual a aliança entre os Iluministas progressistas e Jean Jacques da La Nouvelle Héloïse se encontram: em uma comum rejeição, apesar de d'Alembert, ao geometrismo em benefício da história natural, em outras palavras, na rejeição de um tipo de abstração redutiva em favor de uma aproximação cumulativa e descritiva da realidade duplamente múltipla e incansável." LE DANTEC, op cit, p 131.

62 HUNT, John Dixon. Gardens and the Picturesque. Studies in History of Landscape Architecture, The MIT Press : Cambridge/Massachussets, $p$ 122. 
Brown afirmaria poder falar diretamente, sem mediações, a linguagem das coisas mesmas: o ideal imutável e permanente, modelo pretensamente clássico, era revelado a partir dos acidentes e variações do lugar. A imagem de seus jardins são aproximações da doce e arbitrariamente limpa Arcádia, extensos gramados ininterruptos e árvores em arranjo que tem como guia a ondulante linha que modela o relevo; pouca, apenas a imprescindivel, arquitetura ${ }^{63}$. Brown acreditara no poder da organização humana sobre o fenômeno natural, a variedade proporcionada pelo projeto copiava a natureza e assistia suas operações: ela era modelo em ambas as dimensões. Contudo, Brown foi homem de muitas obras e pouca escrita, ao contrário de Humphry Repton, que a historiografia a princípio localizou como seu seguidor, e que em tempos atuais surge como alguém cuja produção se destaca de Brown especialmente no que diz respeito às suas estratégias e desdobramentos ${ }^{64}$.

Sua afirmação, de que raramente um só autor poderia de fato se expressar teórica e praticamente sobre os jardins, revela a intenção presente em seu ensaio, Observations on the Theory and Practice of Landscape Gardening, 1803, de reunir essas qualidades e empreender uma reflexão que leve em conta os dois lados dessa questão ${ }^{65}$. Repton possuía grande habilidade de desenho e se utilizava de um expediente no qual apresentava a imagem do jardim que trabalhava antes e depois dos melhoramentos. Seus livros vermelhos, Red Books, eram escritos e copiosamente desenhados. Sua prática selecionava belezas de diferentes estilos e os adaptava a cada lugar ${ }^{66}$, o que por princípio o afasta de Capability Brown e o aproxima de um novo ideário e período.

63 "O reverso do desenvolvimento Renascentista estava agora completo, No século XV na Itália, o arquiteto tomou posse do jardim pelo interesse da unidade artística; no século XVIII na Inglaterra, o jardineiro tomou as arquiteturas pela mesma razão. (...) Brown desenvolve o ideal de mundo privado da sociedade que serve. Era um mundo não forjado pelo homem, mas pela Natureza, porém uma Natureza em forma limitada, opulenta, rotunda, fecunda e feminina. Ele deu forma e unidade e equilíbrio às idéias de Kent". CLIFFORD, op cit, pp 156 e 157.

64“Ele [Repton] visa antes de tudo à criação de um conjunto e à congruência dos edifícios, do entorno, das pessoas - preocupação crescente no decorrer do século - o que ele consegue [dá-se] por um estudo minucioso dos efeitos comparados dos diversos segmentos da paisagem. Ele leva em conta o que conduz o olhar e as ilusões produzidas por este trajeto; indicando em particular como elementos da paisagem que conduzem a visão, as árvores (...) e a água (...). Ele mostra que a arte dos jardins apresenta diferenças em relação à pintura, dentro de princípios comuns; assim, as leis da perspectiva, bem como a sombra e a luz, são aplicadas de modo diverso; a pintura é feita para ser observada de um só ponto, mas a paisagem é feita para ser vista por um observador que se desloca; a pintura tem necessidade de sombra e de luz, enquanto que a paisagem pode ser inteiramente iluminada.". Sobre Sketches and Hints on Landscape Gardening, 1794, de Humphry Repton, in MARTINET,op cit, pp 234 e 235.

65 HUNT, op cit, p 140.

66 Em outro ensaio, Enquiry into the Changes of Taste in Landscape Garden, 1806, Repton investiga os quatro requisitos necessários a essa arte. Clifford afirma ser Repton o inaugurador de um ecletismo que atribuirá filigrana ao caos. CLIFFORD, op cit, p169. Repton seria o primeiro a se 
Os modos pelo quais se empreendiam os melhoramentos já haviam sido objeto de crítica por William Gilpin, que escreve no ensaio, Observations, Relative Chiefly to Picturesque Beauty made in the year of 1772; nele argumenta contra as reformas realizadas por Brown, em especial os relacionados à ruína, que eram normalmente removidas 67 .
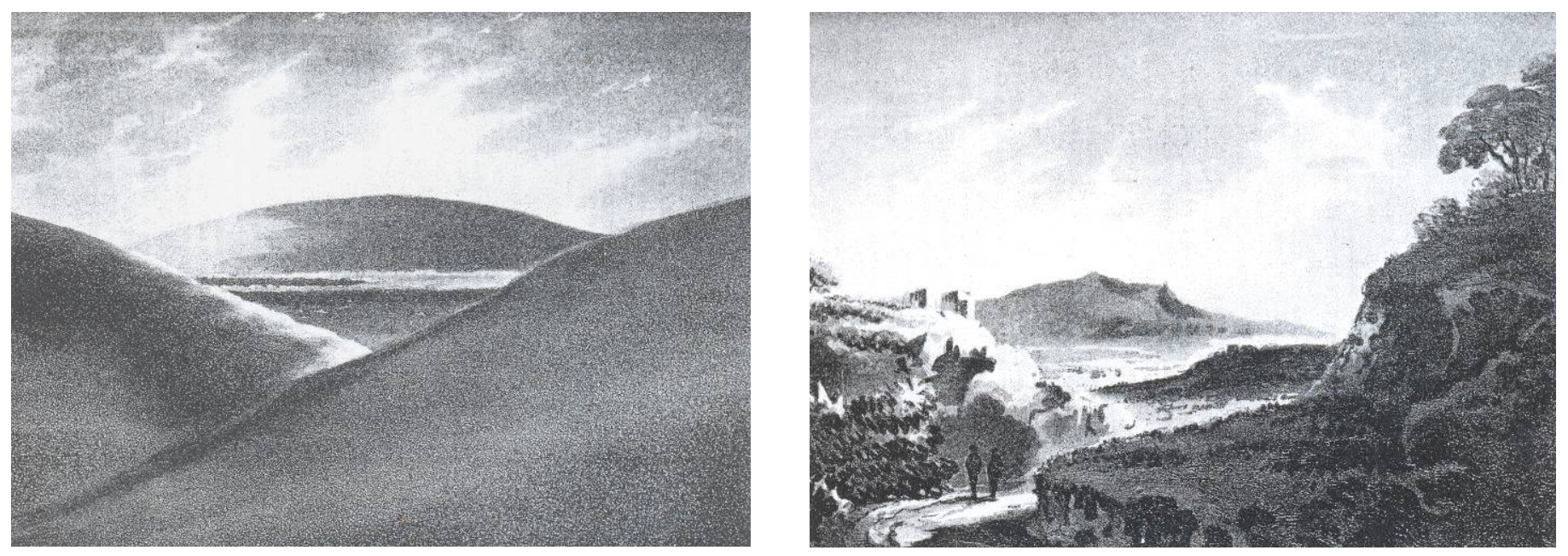

fig. 10 - Pintura de William Gilpin em Três Ensaios (1792) mostrando a diferença entre uma cena sem elaboração e outra com composição pinturesca

A mímesis pretendida nesses projetos e intervenções passa por forte ataque na viragem dos séculos XVIII e XIX. Uvedale Price e Richard Payne Knight pregam a revisão do ideário naturalístico que afirma copiar poeticamente a natureza; a experiência da natureza, afirmavam os defensores do pinturesco, tinha tom maior que as proporcionadas pelas ambiências de Brown e, para eles, a realidade e sua mímesis invocava idéias mais complexas.

\footnotetext{
auto denominar landscape gardener, embora a locução já houvesse sido utilizada por William Shenstone, poeta e proprietário de modestas terras, em seu ensaio, Unconnected Thoughts on Gardening, 1743. COFFIN, op cit, p 37.

67 Em 1776, Gilpin visita outra obra de Brown em Yorkshire, Sandback Park, e lastima o resultado que transformou a ambiência de uma antiga Abadia em verde, brilhante e pelado morro COFFIN, op cit, p 55.
} 
A popularização do Pinturesco por William Gilpin 68, em suas várias viagens descritivas pela Inglaterra, suas recomendações acessíveis e desenhos, são o ponto de partida para uma empreitada de maior envergadura teórica pretendida por Price e Knight.

Os limites de uma possível definição para o Pinturesco, entretanto, são pouco nítidos. Relacionam-se mais com uma prova pelo exemplo do que assertivas numa linguagem teórica, muito embora elas tenham sido elaboradas. Ao mesmo tempo em que o Pinturesco aparece como uma reação ao modo de compor que busca controlar todos os elementos constituintes, ele refuta uma elaboração visível, numa atitude claramente endereçada à retórica. O naturalismo de Brown, que afirmava em seus contratos construir seus jardins com os sentimentos do poeta e com o olhar do pintor, era objeto de controvérsia e desprezo pelo público culto que desenvolvia a percepção pinturesca no período; a produção de Capability Brown era acusada de ser repetitiva e mecânica. A mistura (mixture), base da composição pinturesca, é empregada para interromper esses domínios percebidos como monótonos e instalar outros mais complexos.

Uvedale Price em seu ensaio On the Picturesque 69, 1794, confessa lamentar-se de um momento em sua atuação quando, ao empreender melhorias em um jardim, arrasa o que lá existia, o Antigo, em prol do que então chama Moderno; nesse momento Moderno implica muito mais em uma postura ou atitude, do que a mistura de tipos contrastantes. Com o passar do tempo, ele se aperceberia de que a combinação entre padrões distintos traz à paisagem algo que captura a atenção e promove singular experiência 70 . A questão do contraste e da variedade remete uma vez mais à retórica, contudo, o modo pelo qual essas figuras são utilizadas distende

\footnotetext{
68 Alguns autores afirmam que a normatização do Pinturesco já aparece em Gilpin em 1772 quando este o define como "o quebrado e o abrupto, o que evita a ordem geométrica, o que pode identificar-se com o natural". In SILVESTRE e ALIATA, op cit, p 75.

69 "A noção sobre o Pinturesco é exposta em um tratado de 1794 e argumentado em três ensaios em 1798; ele [Uvedale Price] define a paisagem pinturesca como aquela que será agradável pintura, reação da arte sobre a percepção da natureza." MARTINET, op cit, p 246.

70 "O que pode ser misturado, em que proporções, e em que grau constitui grande parte da controvérsia sobre composições estéticas e políticas que aparecem em livros e artigos de revistas em fins do século XVIII". ROBINSON, op cit, p 2.
} 
qualquer regra. Não se trata de uma linguagem pública cujo significado esteja subsumido a alegorias; ela parte do espectro individual e repercute segundo essa especificidade.

A Natureza expressa a mudança através seu crescimento, variedade de formas e texturas, modificando-se ainda pelas diferentes estações. 0 descompasso entre a experiência de Natureza e o ideário de permanência e constância estabelecido em algumas filosofias engendra o espaço de percepção de uma Natureza que se desvia de qualquer regra óbvia. o Pinturesco se refere à Natureza, ela é seu mote e motivo, uma mímesis na qual o artifício cumula de sentidos aquilo que parece haver sido produzido pelo acaso.

Outra característica que ensaia a disposição pinturesca é o uso de menor poder do que o disponível para compor as partes num arranjo que não pretende, ou pressiona, a conclusão. Essa produção, que relaciona partes e que pretende parecer obra de acaso, é na verdade resultado de escolhas conscientes. Sua prática receberá, contudo, no que diz respeito à experiência que é capaz de criar, críticas por parte de teóricos e praticantes de jardins sob o domínio de outras inspirações ${ }^{71}$.

A acumulação dos tempos, a imagem que resulta de sua passagem, a mudança, são modelos para o tipo de mistura pretendida. Quando os gentis homens teóricos do Pinturesco realizam suas viagens à Itália, os jardins Renascentistas que visitavam tinham mais de duzentos anos. As arquiteturas mantinham-se, mas o tempo lhes transformara a feição, algumas ruinosas, outras cobertas de musgo e hera, toda a vegetação crescida alterava a original disposição e suscitam outras questões se constroem à luz dessas experiências. Quando o Pinturesco for aplicado à arquitetura, Richard Payne Knight 72 recomendará o estilo misto, não distinguindo modo de execução, ou classe de ornamentos: a ausência de linhas de separação diz respeito a uma postura que abrange tanto a questão da continuidade de leitura de um território, tornado em sua totalidade paisagem pela ausência de visual

\footnotetext{
${ }^{71} \mathrm{~A}$ crítica elaborada acerca da hipocrisia inglesa, natural fabrique, e os esforços necessários para obter a pura paisagem, na qual quase tudo é puro artifício e cópia em resultado profundamente tedioso, esse sem dúvida a mais grave ofensa, é elaborada por exemplo por Charles-Joseph de Ligne, the prince of fabriques, 1781, e aparecem no artigo de Monique Mosser, 'Paradox in the Garden: A Brief Account of Fabriques', in The History of Garden Design, the Western tradition from Renassance to the present day. Editores MOSSER, Monique and TEYSSOT, George. Thames \& Hudson : London, 1991.

72 Autor do escrito An Analytical Inquiry into the Principles of Taste, 1805, Richard Payne Knight se empenha em demonstrar “... como diferentes modelos de transposição de idéias resultam do jogo variado entre sensações e associações de idéias. Ele critica as qualidades objetivas pelas quais Burke irá caracterizar o sublime, e Price o pinturesco". MARTINET, op cit, 260.
} 
das cercas, quanto às partes que constituem as arquiteturas; em outras palavras, à separação que a regra imprimia na maneira de pensar o projeto, identificando cada parte e determinando que ordem utilizar.

Ao afirmar a mistura como elemento constituinte, o Pinturesco inclui elementos comumente excluídos graças às suas qualidades obscuras; a incongruência visível em lugares como Boboli, em Florença, e Bomarzo, em Viterbo, estivera restrita ao jardim; essa percepção, ainda que destituída de suas formas mais construídas e alegóricas, explodiria os limites de um espaço cerrado e agora a Arcádia soturna, rústica e grave nesse século XVIII move-se pela paisagem.

O jogo que se estabelece evita regras de um sistema fixo; ajustando-se a diferentes condições, o equilíbrio na arte da composição corre sempre o iminente risco, seja da perda de significado pelo exagero da mistura, seja pelo excesso de estímulo, que termina por homogeneizar a experiência. 0 simples desejo de mudança em si é mórbido, afirmaria Knight, mesmo a
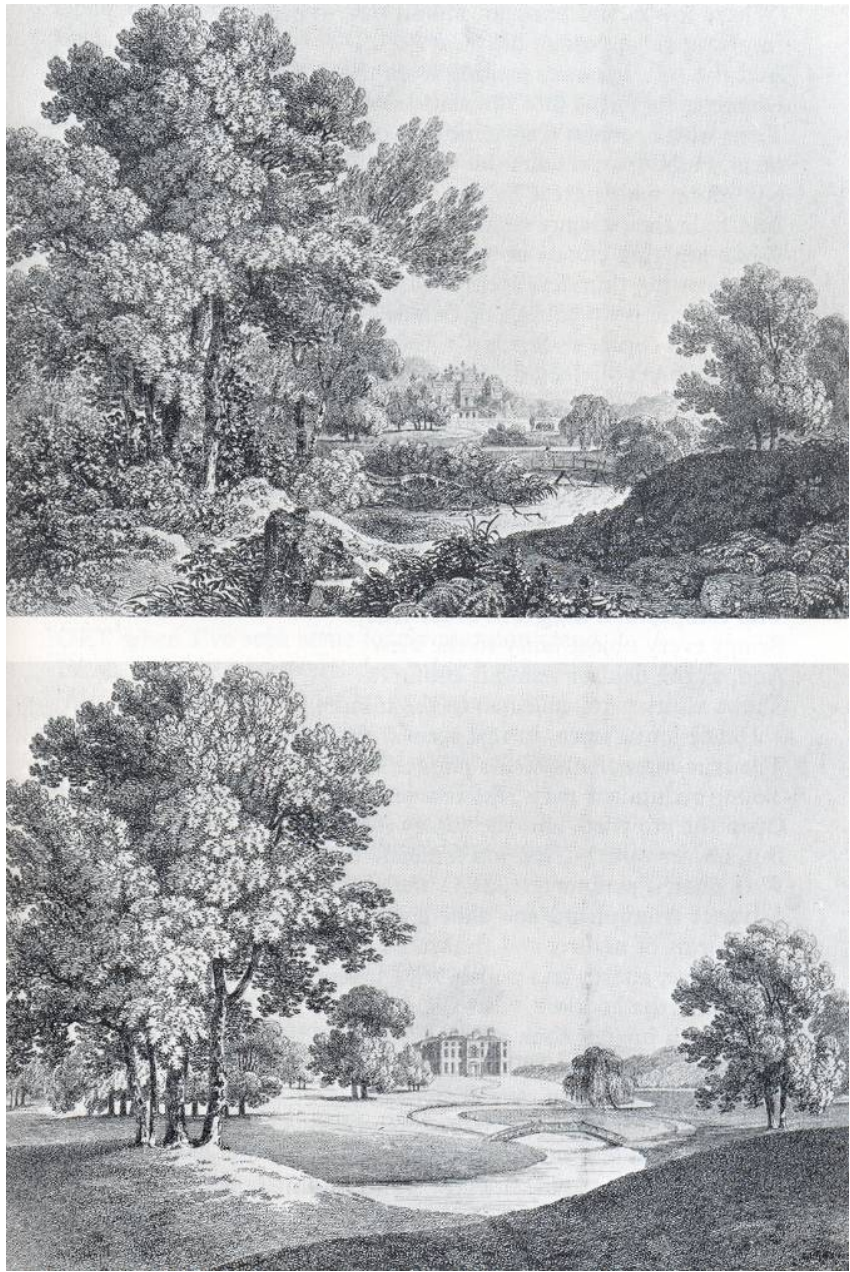

fig. 11 - Contraponto entre composição pinturesca e representação segundo perspectiva de Capability Brown

novidade e variedade podem significar um novo e entediante padrão. 0 poema didático The Landscape ${ }^{73}$, 1794, expõe a doutrina pinturesca onze anos antes do escrito Analytical Inquiry into the Picturesque of Taste,

73 "Primeiro fixa os pontos onde desejas ir; / Então deixa o simples modelo espontaneamente fluir;/ Sem curvar-se a nenhuma afetação, ou artifício,/ Que te leves ainda mais longe do fim:/ Para, conforme o princípio do gosto dispõe,/ O que quer que seja evitado do sentido, ofende." 
que torna claro no que os versos implicavam: que o pinturesco é, com efeito, uma teoria de associação, uma função da imaginação ${ }^{74}$.

A alternância entre surpresa e descanso engendra a curiosidade, essa sim, sem descanso. Uvedale alude ao estímulo (irritation), esse é o objeto da ação e a vida dos prazeres: emoções suaves são interrompidas por outras emoções, rápidas, ásperas, impetuosas; e vice versa: a composição não ambiciona a recuperação do equilíbrio, mas a manutenção contínua dos contrastes.

Price identifica também a condição de abrupta variação entre partes como característica do Pinturesco 75; contudo não se deve perder de vista o paradoxo que essa postura parece interpor à afirmação da ausência de linhas de separação. Desafiante coreografia essa que se desenvolve pela mistura, mas que deve contar com a surpresa como trunfo contra o tédio, esse sempre perigoso inimigo do século.

Shenstone, autor de Unconnected Thoughts on Gardening, de 1765, asseverava que uma seqüência de gramados era bela, mas causaria enjôo ${ }^{76}$ se não fosse possível alternar sua vista com cenas selvagens; apenas a partir do contraste é que os gramados seriam tornados, uma vez mais, graciosamente novos e belos. 0 Pinturesco é também uma reação a essa condição de plenitude nefasta. A apaziguada percepção estética é banida em favor de uma espiral de emoções e sensações.

Filho do primeiro ministro Sir Robert Walpole, o gentil homem Horace Walpole, que escrevia sobre jardins, fora educado numa geração informada pelos escritos de Addison e Shaftesbury, bem como por imagens de Salvatore Rosa, napolitano cuja obra seria apreciada e colecionada por ingleses, especialmente por suas qualidades mais

KNIGTH, Richard Paine. 'The Landscape', apud HIPPLE Jr, Walter John. The Beautiful, The Sublime, \& The Picturesque in Eighteenth - Century British Aesthetic Theory. New York: The Southern Illinois University Press, 1957, pp 248 e 249.

74 "Como os prazeres do intelecto devém da associação das idéias, quanto mais se multiplicam as associações, mais a esfera desses prazeres serão ampliadas.(...) Para os olhos do observador desavisado, o sublime espetáculo dos céus apresenta nada a não ser a abóbada azul adornada de brilhos: mas, ao letrado e ilustrado, ele dispõe inumeráveis mundos, distribuídos através da imensidão variada do incomensurável espaço." KNIGTH, Richard Paine. 'Analytical Inquiry into the Picturesque of Taste'. Apud HUNT, John and WILLIS, Peter. The Genius of the Place Tthe English Landscape Garden 1620-1820. The MIT Press : Cambridge Massachussets, 2000, (1988).

75 “...desejo de identidade. O Pinturesco é certamente uma asserção nesses termos. Faz sentido apenas contra um fundo que permite o elemento/padrão ser identificado, mesmo que a preservação daquela identidade requer constante ajuste. O paradoxo reside na assertiva de promiscuidade, a qual, plenamente levada a termo pode resultar na auto-destruição". ROBINSON, op cit, p 2.

76 ROBINSON, op cit, p 8. 
selvagens na representação. Quando convida o amigo e poeta Thomas Gray em 1739 para acompanhá-lo numa viagem pelos Alpes, o que os interessava não era vivenciar de uma epifania com o onipotente Todo-Poderoso, mas sim experimentar sensações. Sua jornada fora projetada para levá-los próximos do limite, para brincar com o desastre ${ }^{77}$. Nesse mesmo ano surge a tradução diretamente do grego, por William Smith, do tratado sobre retórica atribuído à Longino, no qual o capítulo 35 é inteiramente devotado à figura do sublime.

\section{as origens do sublime}

Um escrito de qualidade teológica de autoria de Thomas Burnet, Telluris Theoria Sacra, ou Teoria Sacra da Terra de 1681, fora admirado pelo jovem Addison que escreve a Burnet uma Ode em latim agradecendo a tão vital conhecimento ${ }^{78}$. A fala de Burnet, futuro bispo de Salisbury após a Revolução Gloriosa de 1688, mirava as posturas filosóficas de Cambridge, almejando provocar uma mudança nessa perspectiva complacente e ideal. Baseava sua argumentação numa percepção de realidade muito mais eloqüente e profunda, uma Natureza que provoca o apreço pelo irregular e pelo acidente: 0 que Burnet oferecia em lugar da asseada e bem-posta cosmologia era um estupendo e primordial drama. Ao invés do divino relojoeiro, o Jehovah que havia feito as montanhas era sublime, senão furioso, dramaturgo 79 .

Edmund Burke publica seu tratado Philosophical Inquiry Into the Origin of Our Ideas of the Sublime and the Beautiful, Uma Investigação Crítica acerca da Origem de nossas Idéias de Sublime e de Belo, em 1757. 0 que torna especial seu escrito é que ele estabelece as bases de uma compreensão acerca do Sublime que desdobrariam o significado clássico.

O percurso se origina a partir de um texto anônimo, atribuído a Dionísio Longino, no Século I, Peri Hypsous ou, sobre a elevação do estilo, traduzido para o latim como De Sublimitate, o Sublime. Duas publicações são

\footnotetext{
77 SCHAMA, op cit, p 449.

78 SCHAMA, op cit, p 452.

79 SCHAMA, op cit, p 451. 
realizadas antes da de William Smith de 1739, a primeira no Renascimento por Rebortello em 1554; e uma segunda tradução francesa por Boileau em 1670; o escrito de Burke tem relevância não apenas por atualizar o significado de Sublime no século XVIII, mas por torná-lo categoria estética distinta não apenas do Belo, mas também do Pinturesco 80.

O sublime aparece no texto de Longino no primeiro século como uma figura ligada à relação que se estabelece entre arte e natureza. Essa questão ocupara os Antigos em diferentes tempos; Aristóteles, na Física sustém que a Arte imita a Natureza, a téchne é mímesis da phýsis 81. A questão para Longino se apresenta em mesma chave, a téchne não implica em replicar, a mímesis não é reprodução banal de um objeto, contudo há em Longino uma afirmação de que essa se dá como violenta exaltação, supondo a faculdade de eleição e admiração que se deixa possuir, como a Pítia pelo sopro de Apolo 82; a experiência da criação permite e pretende rivalizar com o mestre.

Seu escrito investiga a criação a partir da constatação de que a técnica é insuficiente para a produção de uma obra. Para que obra seja memorável, acredita-se, deve existir o dom, e aqui está a natureza. Porém Longino elabora de modo a comprovar que, se a natureza tem suas leis, e nisso a maior parte dos gregos concorda, então deve existir um método, um caminho que permita o ensinar dessa arte que produz à semelhança da natureza.

A solução apresentada em seus escritos é a da parenética, conduzir a alma não à ação direta do sábio, mas sim o instigar da atitude conveniente que propicie a visão. A questão é estimular nossos dons naturais para a

\footnotetext{
${ }^{80} \mathrm{Ao}$ separar as duas categorias, Burke engendra espaço para o surgimento de um meio termo que descreveria composições que participavam de ambos. Uvedale Price localizava o Pinturesco em seu ensaio entre o Belo e o Sublime; misto, mas perfeitamente distinto. As discussões sobre as diferenças entre o Belo e o Pinturesco foram mais acaloradas uma vez que, no julgamento de Gilpin e Knight a descrição de Price referendando a de Burke pecava pela excessiva alusão à doçura. Uvedale Price defender-se-ia, (inclusive do próprio Repton, que Ihe escreve assinalando suas contradições), afirmando que seu trabalho sumariza uma totalidade, que inclui a rudeza e a doçura, sem a qual a primeira não apareceria em sua força. Cf. ROBINSON, op cit, pp 17 e 23.

81 “... a quem se empenha em uma téchne, incumbe operar de modo similar e atentado às mesmas regras (nómos) com que a phýsis atua. Entre a téchne e a phýsis há de haver, pois, pela mímesis, relação de isonomia, e esta é um ideal de medida e ponderação, (...). Outrossim, o étimo téchne potencia certa acepção mais ampla e generosa que a do recente termo arte: téchne implica a aplicação de precisos procedimentos consagrados pelo tirocínio ou pela prática para a consecução de certa finalidade ou aviamento de uma utilidade." AZEVEDO, Ricardo Marques. Arte e Natureza, in Nefelomancias, ensaios sobre as artes dos romantismos, texto do autor, janeiro de 2008.

82 LONGINO, op cit, p 27.
} 
grandeza, conspirar pela visão porque na criação não há como estabelecer um caminho claro e distinto. 0 sublime escapa à razão enquanto conceito, de modo que só pode apresentar-se por exemplos; essa mudez na definição é paradoxo que Longino estima: sublime é o que não se enuncia, mas com o que se pode ter contato 83 .

A primeira seqüência de exemplos apresentada por Longino diz respeito situações limites, e o sublime, é a percepção disso: Homero e sua narrativa do salto dos cavalos dos deuses cujo impulso coincide com o espaço do universo; noutro exemplo, o poema de Safo acerca do corpo é apresentado como um concorrer de partes, uma pluralidade de acontecimentos que não compõe um corpo de fato, mas o corpo constituído no poema, essencial. Nesse momento singular é posta em evidência a produção, o processo mesmo, de criação do sublime: a unidade e o movimento são referências do sublime, bem como a idéia de que somos atingidos num golpe por sua força.

O sublime é ainda violento e desequilibra, e segundo a regra do decoro ele não pode ser falseado. 0 desequilíbrio não é uma estratégia que busca o convencimento, o desequilíbrio é o transe e a suspensão de toda razão: o choque suspende o julgamento nos mergulha no êxtase e propicia a visão; o que é admirável é sempre o inesperado.

Longino realiza o elogio do desvio e inscreve o sublime nesse sobre humano que caracteriza o discurso poético e narrativo memorável, a grande arte para os Antigos. o encontro sublime da natureza no artifício dá-se, para Longino, num preciso tempo, melhor dito, na fresta de tempo em que a ocasião apresenta a oportunidade: o kairós grego expressa essa qualidade. Todas essas qualidades localizam o Sublime para além da regra, ultrapassando-a, esse ultrapassar implicava numa figura de linguagem adaptada ao salto, a metáfora 84 .

83 “A admiração bruta é o contato com o pensamento nu, o grande pensamento". LONGINO, op cit, p 19.

84 Enquanto técnica, artifício na criação do sublime, a metáfora presta-se em especial ao lado de duas outras figuras, o hipérbato, a perífrase, o assíndeto, elipse, a ausência de ligação, a mudança de pessoa, a passagem do singular para o plural. 
A publicação de Edmund Burke foi o grande meio de difusão do ideário do Sublime no mundo inglês do século XVIII ${ }^{85}$. Seus escritos refletem acerca dos efeitos da obra sobre a psique humana, e estão informados pelo empirismo inglês, especialmente David Hume. A postura de sua investigação antecede os estudos sobre recepção na arte em geral e colabora na derrocada das regras em relação à produção da obra em curso no mesmo século.

Burke estabelece a idéia do Belo como aquilo que se associa ao prazer e ao deleite, referendando o cânone clássico quando afirma ser o Belo algo alheio às paixões, inscrevendo-se, portanto dentro do território harmônico; nesse sentido é agregador e sociável, um empenho afirmativo da vida. O Sublime, ao contrário, é inscrito nesse doentio território do pathos e relaciona-se ao terror e ao infinito 86.0 sublime para Burke coloca o homem frente à principal sensação de perigo: a ameaça de autoconservação (sic). Impulsiona a reflexão frente aos grandes temas do pensamento humano: o infinito a morte, o sentido da vida 87.

Burke opera a definição do Sublime também através das noções de infinito e em termos do inexprimível, e nessa direção reitera Longino; contudo o ideário que firma o faz a partir do terror, e essa especial da situação relacionada ao perigo de morte não comparece nos escritos do primeiro século. Aquilo que se descrevera como tensão, em momento algum se referiria ao horror que Burke imputará à noção de Sublime. Muito ao contrário, a

85 A segunda edição de 1759 contém adições ao texto com novas argumentações e respostas às criticas realizadas à primeira edição; precede sua investigação de uma Introdução sobre o Gosto na qual ele apresenta o poder que tem a imaginação de reagrupar as imagens; retomando a distinção de Locke entre o espírito que vê as semelhanças (...) e o julgamento que vê as diferenças, conclui que o prazer poético é maior nas semelhanças (por exemplo, as metáforas); ele se aproxima, portanto mais do sentimento estético da imaginação imediata que do julgamento reflexivo. MARTINET, op cit, p 146.

86“Outra fonte do sublime é o infinito. (...) [o] Infinito possui a tendência de preencher a mente de uma espécie de prazeroso horror, que é o mais genuíno efeito, o mais verdadeiro teste do sublime. Há poucas coisas que podem se tornar objetos de nossos sentidos que são, realmente, infinitos em sua própria natureza. Mas o olhar, não sendo capaz de perceber o limite de muitas coisas, elas parecem ser infinitas, produzindo o mesmo efeito que se elas realmente fossem. Nós somos iludidos do mesmo modo que, se partes de algum grande objeto são continuadas em qualquer número indefinido, a imaginação não encontra obstáculo que possa impedi-la de estender [esse número] a seu bel-prazer". BURKE, Parte II, Seção VIII, Infinity, in Philosophical Inquiry Into the Origin of Our Ideas of the Sublime and the Beautiful, apud MARTINET, op cit, p 152.

87 SILVESTRI e ALIATA, op cit, p 91. Esse modo de apresentar o sublime, - originalmente sinônimo de 'estilo elevado', categoria definida por sua vinculação às paixões, relacionando-o à preservação, é uma outra maneira de mostrar que o Sublime responde a um apelo diretamente associado a elas. 
imagem produzida por Longino é de luz, a metáfora que usa é a do relâmpago, como uma revelação; a elaborada por Burke toma do relâmpago a tempestade, o apreço pela situação extrema, de iminente catástrofe 88 .

O nascimento da Estética enquanto campo de investigações acerca do Belo é coetâneo a esse período 89. Immanuel Kant é um dos principais representantes do esforço de tornar o gosto, aquilo que parecera fruto do acaso individual, em algo atinente à razão universal.

Kant tem como ponto de partida a separação da arte e ciência, mas tem como horizonte o equilíbrio entre ambas as instâncias. A Beleza só é passível de ser apreciada pelo sujeito autônomo, relacionando-se aos sentidos e não à razão: o belo é o que é representado sem conceitos como objeto de uma complacência universal; (...) o juízo de gosto não é pois, nenhum juízo de conhecimento, por conseguinte não é lógico senão estético, pelo qual se entende aquilo cujo fundamento de determinação não pode ser senão subjetivo 90.

A Natureza, construída pela Razão humana, localiza o Belo nesse lugar sensível onde se encontram harmonicamente o artifício e a natureza. O Sublime, ao contrário, implica numa distorção, o ultrapassar apresentado por Longino, no século XVIII em Kant, torna-se desfiguração do Belo. Enquanto experiência e representação de um objeto da natureza, o Sublime força nosso espírito a pensar, ao contrário do Belo, cuja natureza diz respeito apenas ao sensível 91.

\footnotetext{
88 "O que quer que estimule o excitar das idéias de dor e perigo, isto é, o que quer que seja de qualquer modo terrível, ou verse sobre objetos terríveis, ou opere em um modo análogo ao terror, é uma fonte do sublime; isto é gerador da mais forte emoção que a mente é capaz de sentir." BURKE apud HIPPLE Jr, op cit, p 87. Hipple acrescenta: Burke não diz, note bem, que o sublime é sempre terrível; ele é também terrível, ou associado a algo terrível, (...) insiste que: "quando o perigo ou a dor estão muito próximos eles são incapazes de nos dar qualquer deleite, e são simplesmente terriveis, mas a certa distância, e com certas modificações, eles podem ser, e eles são, deliciosos, como experimentamos todos os dias"; p 88.

89 Em meados do século XVIII as bases de uma nova disciplina filosófica, a Estética são lançadas; a Arte “... não mais se obriga a ater-se a finalismos utilitários, ou devocionais, tampouco se baliza em considerações iconológicas, metafóricas ou simbólicas, ideais transcendentes, ou cosmologias míticas. De um modo geral, considera-se que o belo seja antes um juízo suscitado pela experiência do sujeito que um atributo inerente ao objeto". AZEVEDO, op cit, p 25.

90 KANT, Immanuel. Crítica da Faculdade do Juízo. Rio de Janeiro: Forense Universitária, 1995. pp 48 e 56.

91“... esse pensar mais além dos limites, que coloca o observador estupefato frente às profundidades do sagrado, é despertado - e controlado pela recepção estética. Isso torna a arte a grande alternativa frente a nossa possível imobilidade frente ao mundo: sem a mediação da arte assim entendida, o homem ficaria inerte frente ao mundo." SILVESTRI e ALIATA, op cit, p 93.
} 
Afirmar o Belo em detrimento do Sublime é decisão que se associa aos interesses sociais da época: a harmonia e o enlevo são sensações aprazíveis, sentencia Burke já na Introdução do ensaio. Também ali aparece a idéia de que o gosto não é acidente, mas algo que se cultiva. Essa idéia, cuja origem remonta ao século XVII, repercute uma associação entre gosto e caráter, questão compartilhada tanto por Humphry Repton quanto pela a romancista Jane Austin: um refinado gosto estético denota excelência de caráter moral ${ }^{92}$.

Muito embora a Arcádia soturna houvesse ganhado status de paisagem, a produção dos jardins no depoimento de seus autores se fazia segundo as necessidades e convenções de seus clientes, o que levava Repton 93, em finais do século XVIII, a atenuar deliberadamente possíveis efeitos assombrosos que alguns lugares poderiam produzir. Essa arte desenvolve seus efeitos na direção da agradável surpresa, e segue evitando o domínio do cenário selvagem que aparece apenas como variação fugidia, uma aspereza de configuração pinturesca.

O prazer da cena persegue o Belo e o Pinturesco que seriam destruídos pelo horror que toma parte no Sublime ${ }^{94}$ de então.

\section{o sublime tornado aprazível ou uma percepção na qual a mímesis ultrapassa a phýsis}

Quase cem anos separam as primeiras predisposições pinturescas pelo irregular, áspero e abrupto à verdadeira febre que passa a imperar na procura dessas cenas, deambulando pela Natureza. Os teóricos do Pinturesco

\footnotetext{
92 HUNT, (1992), p 163.

93 “É importante notar a importância da associação no pensamento de Repton. Como aquelas de Price e Knight, as regras estéticas e o julgamento de Repton dependem fortemente da associação - não havendo quase nenhum traço da psicologia de Burke - mas as classes de associação operam de modo distinto. O que Repton chama 'associação' não tem ordem primeira de importância em construção de sua teoria, embora sua apreciação seja 'uma das mais impressivas formas de deleite; se suscitada por um acidente local, (...), pelas lembranças de uma antiguidade, como a ruína de um claustro, ou castelo; mas mais particularmente pela ligação pessoal à objetos conhecidos de longa data...como um lugar favorito para se sentar, uma árvore, um lugar singularizado pelas lembranças de eventos passados, (...)'. Essas circunstancias pessoais ou históricas dispõe associações mais concretas que abstratas, esse é o tipo de associação só foi levada a termo por Repton." HIPPLE Jr, op cit, p 233.

94 “Nascido do oximoro de agradável terror, o Romantismo foi nutrido pela calamidade. Enquanto o século XVIII foi convencionalmente pensado como uma época de luzes - o lluminismo, (...) Edmund Burke coloca-se a si mesmo como sacerdote do obscuro, da escuridão. Ser profundo era perscrutar as profundezas, (...). E é muito mais importante, ele argüi, a encarar tal terrível sublimidade que banhar-se no brilho da complacente iluminação". SCHAMA, op cit, p 450.
} 
afirmavam que aquele que desenhava o jardim deveria aprender sua arte através da natureza e do artifício, especialmente pela pintura. Da primeira, emular com ênfase os acidentes - uma vez que é neles que se vislumbra a profundidade de significado; o segundo termo, artifício, ensinava a empreender a combinação das várias partes num todo coerente ${ }^{95}$. A diferença era que não se tratavam mais de lugares que haviam sido objeto de projeto, mas da procura por paisagens que satisfizessem uma visão forjada no último século, uma percepção, essa sim projetada e sequiosa por lugares cuja rudeza e imensidão expusessem o infinito e desafiassem a descrição. 0 meio termo do Pinturesco 96 pende nesse momento para o outro dos limites que não o Belo: a harmonia mostrava-se rota e tediosa, o apreço pelo Sublime e sua potencia surgia como intensa e possível comoção.

Nascido em Londres em 1819, John Ruskin teria em sua infância e adolescência a oportunidade de palmilhar o território inglês e escocês junto à sua família guiada por seu pai, comerciante de vinhos ${ }^{97}$. Ruskin testemunha seu apreço pela Natureza em seus escritos 98, à qual associa a figura de Mãe, cuja imagem suscita ensinamentos, respeito e afeto; ele será chamado o filósofo da natureza e do coração humano. Sua fala referenda uma tríade que nessa época já fazia parte por completo da cultura inglesa: viagens, educação e paisagem, chamada por Ruskin poderosa escola das mentes.

Em 1837, seguira para Oxford para aperfeiçoar seus estudos, mas após dois anos apresenta séria anemia e empreende viagem à Itália para recuperar-se; lá vive o contato direto com a chamada cultura clássica. Ao retornar em 1840 publica o primeiro volume do Modern Painters, que o lança como importante escritor no que

95 CLIFFORD, op cit, p 166.

96 O livro de Christopher Hussey de 1927, The Picturesque: Studies in a Point of View, é tido pelos dois autores, Hunt, (capítulo 6. Picturesque Mirrors and the Ruins of the Past, p 173), e Richardson, (Prologue, p xiii), como aquele que localiza o Pinturesco como interregnum entre Clássico e Romântico.

97 A mãe seria responsável por sua ligação e leitura incansável das Escrituras. Cf. GARCIA, Celso. La Naturaleza y el Hombre, (seleciones de John Ruskin). Madrid : Nueva Biblioteca Filosofica, 1933.

98“Se bem que a ausência de amor à Natureza não seja razão suficiente para condenar a ninguém, sua presença é distinção infalível da bondade de coração e de justiça na percepção moral; ainda que de nenhuma maneira da moral prática". Capítulo XVII da quarta parte de Modern Painters: A Natureza e o Homem. Apud GARCIA, op cit, p 9. Essa frase deixa de condenar o que era condenável em Rousseau. 
se refere ao tema da paisagem; além de localizá-lo, a partir de então, como um dos principais críticos desse período 99.

A acusação de que a educação formal destruía o amor à natureza é objeto de argumentação do Capítulo XVII, $A$ Natureza e o Homem, do The Modern Painters: o predomínio das palavras e das abstrações em geral tinha efeito desolador sobre a percepção do aluno; o modo como estava estruturado o ensino causava um desserviço à liberdade criadora: os estudantes dóceis e de bom comportamento são educados na cegueira e na atrofia de metade de suas faculdades 100.

Essa liberdade repercute uma vez mais a fala de Rousseau, a natureza fala em nós, a liberdade dos olhos e das mãos produz desenhos que expressam sua voz: o amador da natureza não é associado ao mais inteligente, mas sem dúvida ao que tem uma inteligência que se situa para além da comum; ao mais sensível, suscetível às maiores emoções e mesmo à alma fragilizada pelo amor, dor e paixões. Contudo, são esses os dotados com sentimentos muito valiosos para a humanidade 101.

O capítulo XIX da quinta parte tem como subtítulo Ensinamentos da Criação e se inicia pela afirmação de que as regiões montanhosas são inevitavelmente melancólicas; mas a um só tempo, a manifestação da beleza da obra de Deus e de sua cólera, um contraste que revela a face religiosa de um autor preocupado em demonstrar que a cada coisa boa corresponde uma má, prova da justeza e sabedoria divina. Entretanto, não se trata apenas de um contraste moral, mas fundamentalmente sensivel, visual. 0 contraste reaparece mais à frente quando às comumentes linhas curvas que compõem a natureza são contrapostas às montanhas e suas sublimes imagens: a agudez do cristal, os fragmentos rochosos e convulsões do solo; raras formas que nos proporcionam o

\footnotetext{
99 Os cinco volumes ou partes da publicação Modern Painters tem como temas: V1: Of General Principles / Of Truth; V2 Of Imaginative end Theoretic Faculties; V3 Of Many Things; V4 Of Mountain Beauty; V5 Of Leaf Beauty / Of Cloud Beauty / Of Ideas of Relation.

100 RUSKIN, Modern Painters, apud GARCIA, Celso. (seleciones de John Ruskin). Madrid : Nueva Biblioteca Filosofica, $1933, \mathrm{p} 11$.

101 RUSKIN, apud GARCIA, op cit, p 12. (Modern Painters, parte IV, cap XVII).
} 
verdadeiro contraste das linhas violentas 102. O impacto da amplidão, a grandiosidade dos espaços como um lugar inesquecível é outro aspecto que imprime à sensibilidade, experiência memorável 103.

A grande inversão acerca da qualidade na percepção desses espaços, que se iniciara em fins do século XVIII, mas nesse momento se configura como anseio estético de mudança que clama: deveríamos considerar todas as superstições que nascem das montanhas como uma forma de poesia, (...) desejaria que [0 leitor], as considerasse não apenas como centro de energia imaginativa, senão também de pureza na doutrina e na prática 104.

O céu imenso por sua vez é o lugar no qual a natureza produz suas maiores belezas, Ruskin o percebe em sua mutabilidade um paralelo às paixões humanas; o céu é para todos, mas mal o percebemos, sua potencia poética é pura comoção, mas nossa atenção insuficiente: quem viu o fugidio raio de luz que, vindo do oriente, foi morrer nos altos píncaros das nuvens e as ligou e desvaneceu, reduzindo-as a mansa chuva e de finas gotas? 105 Nos céus, ainda, o capricho em eterna evolução das nuvens, mote infinito para a imaginação; pergunta Ruskin: porque desvanecem, não quando sai o sol, senão quando se põem, e deixam resplandecer as estrelas do crepúsculo, enquanto o vapor do vale se torna a estender como uma mortalha sobre a terra? 106

A sensibilidade para vivenciar essas qualidades está vinculada a uma experiência física, é o sentimento corpóreo agudo que inicia essa apreensão; no momento imediatamente seguinte, entretanto, é incorporado pela reflexão e memória, que necessitam retê-los e recordá-los; (...) porque quanto mais imaginação e sensibilidade possui uma pessoa, mais facilmente cai em erro, porque vê o que deseja ver, e admira e julga com seu coração

\footnotetext{
102 RUSKIN, apud GARCIA, op cit, p 18. (The Modern Painters,livro II, parte III, seção I, cap V).

103 Pouco menos que 200 anos transformaram completamente uma percepção:“Todo objeto vasto, escreve Saint-Évremont em 1685, é incompativel com a beleza, pois inspira horror. As imensas florestas, as planícies muito largas e os jardins ilimitados são horríveis; nesses lugares incômodos, 'a visão se dissipa e se perde'. A busca da beleza ordena que se ponha obstáculos à desmedida; o artista deve evitar que o espírito se extravie; cabe a ele, assim como Deus soube conter o abismo, impor limites à visão". CORBIN, Alain. O território do Vazio. A Praia e o Imaginário Ocidental. São Paulo : Companhia das Letras, 1989, p 133.

104 RUSKIN, apud GARCIA, op cit, p 61. (The Modern Painters., livro IV, parte V,cap XX).

105 RUSKIN, apud GARCIA, op cit, pp 28 e 29. (The Modern Painters., livro I, parte II, sec III, cap I).

106 RUSKIN, apud GARCIA, op cit, p 33. (The Modern Painters., livro V parte VIII, cap I).
} 
e não com seus olhos ${ }^{107}$. O pretenso erro tem nessa construção valor positivo, a imaginação se alimenta dessas associações e dá à experiência a medida exata que deva ter no espírito.

O gosto de John Ruskin se forma originalmente dentro da perspectiva do Pinturesco, embora o renuncie publicamente a partir de 1860, e passe a utilizá-lo de modo pejorativo para indicar um lugar que parece ser apenas um testemunho das habilidades de composição seu artista. Contudo, essa percepção pinturesca persiste em seu espírito e impregna suas críticas que são elaboradas a partir dessa particular visão, como por exemplo, testemunha a reutilização do datado termo Genius Loci 108.

Afirmaria Ruskin ser o pintor Turner superior aos outros artistas precisamente porque se esses últimos observavam e gravavam com maior acuidade os aspectos do fenômeno natural; Turner, ao contrário, não praticava a precisão topográfica, ele criava a sua própria, ao que Ruskin denominou topografia turneriana 109. Num grande trabalho de imaginação, defende o crítico, a arte da paisagem não pode ser mera cópia: o descompasso entre a cena e a representação é motivo de elogio por Ruskin: é bonito ver como Turner arranja e elimina, escreve Ruskin em carta ao pai ${ }^{110 .}$

Suas descrições acerca das imagens presentes numa paisagem muitas vezes soam contraditórias, é necessária a devida mediação para ultrapassar explicita alusão religiosa e visualizar a poética latente. Ruskin estabelece uma chave crítica a partir da compreensão de que, a utilização da linguagem verbal no tratamento de algo não verbal, demanda expedientes que afrouxam e estendem o verbal ${ }^{111}$. Essa hipótese nasce pela primeira vez com John Ruskin, mas certamente já se ouvira soar algo correlato desde o tratado de Longino.

107 RUSKIN, apud GARCIA, op cit, p 22. (The Modern Painters., livro I, parte II, sec I, cap II).

108 RUSKIN apud HUNT, op cit, p 193. John Ruskin and the Picturesque, é o ensaio que compreende o 7o. capítulo do livro. Ruskin atualizaria a compreensão do Genius Loci ao lado de Turner como algo escondido, percebido e revelado com esforço. Cf. HUNT, op cit, p 221.

109 Cf. HUNT, op cit, p 215 a 239. Capítulo 8o. Ruskin, "Turnerian Topography" and Genius Loci.

110 Datada de 21 de agosto de 1845. RUSKIN apud HUNT, op cit, p 217.

111 “...as palavras não são acuradas o suficiente, delicadas o suficiente, para expressar ou traçar a constância, que impregna as finas linhas e vagas sombras que atravessam o trabalho de Turner". RUSKIN, Modern Painters, apud HUNT, p 200. 
As palavras não eram precisas o suficiente para lidar com o desafio de descrever imagens que rompem com a tradição iconográfica da pintura alegórica e mitológica ${ }^{112}$. Ruskin está convencido de que a paisagem resulta de um processo de elaboração e que a arte de Turner oferece da paisagem uma maior e mais profunda verdade relacionada ao lugar.

Muitas vezes Ruskin invoca a tradição da metáfora artística - uma metáfora que nasce sustentada por seu espelhamento na Natureza. Contudo o espelho está longe de refletir um idêntico, produz no mais das vezes uma imagem insatisfatória, incompleta: todo objeto, mesmo próximo dos olhos, tem algo que você não pode ver, e que traz o mistério da distância mesmo às partes que supomos ver mais distintamente 113.

O verdadeiro artista afirmava, tinha no poder da invenção algo de profeta, parte do que apresenta sequer aparece em sua representação, há aqui no espaço do invisivel lugar para notáveis associações; ao mesmo tempo esse artista torna aquela representação inútil às apreensões das ciências, nesse sentido escapando à regra, e ao valor quantitativo.

É possível vislumbrar a figura do sublime nesta última passagem que trata de um espaço invisível, bem como nas outras duas, a saber, uma primeira que afirma a necessidade de uma especial linguagem, poética, metafórica, para o tratamento e descrição dessa arte que por si explode na tela; e a segunda na qual Ruskin fala da compreensão ser algo que vê para além dos olhos.

Essas idéias que participam da cultura de uma época atravessam o tempo estabelecendo contato com o Moderno do século XX. Essa relação interessa na medida em que, ao contrário da pretensa falência da história propalada pela Modernidade, a sobrevivência desse contato sob diferentes matizes indica que essas figuras ainda operam nos modos de percepção e construção paisagem.

Burke atribuíra excelência à poesia em detrimento da pintura. Os expedientes da escrita seriam mais capazes de criar o sublime de então; a pintura, constrangida pela representação figurativa no século XVIII, nada pode

112 HUNT, op cit, p 201.

113 RUSKIN, apud HUNT,op cit, p 209.

86 
realizar que se assemelhasse ao êxtase propiciado pela palavra. A experiência dessa liberdade viria mais tarde, quando a obstinação em representar a figura ultrapassasse a própria figura e suas imagens. Entre outros expedientes, a mímesis pareceria então ceder lugar à metáfora.

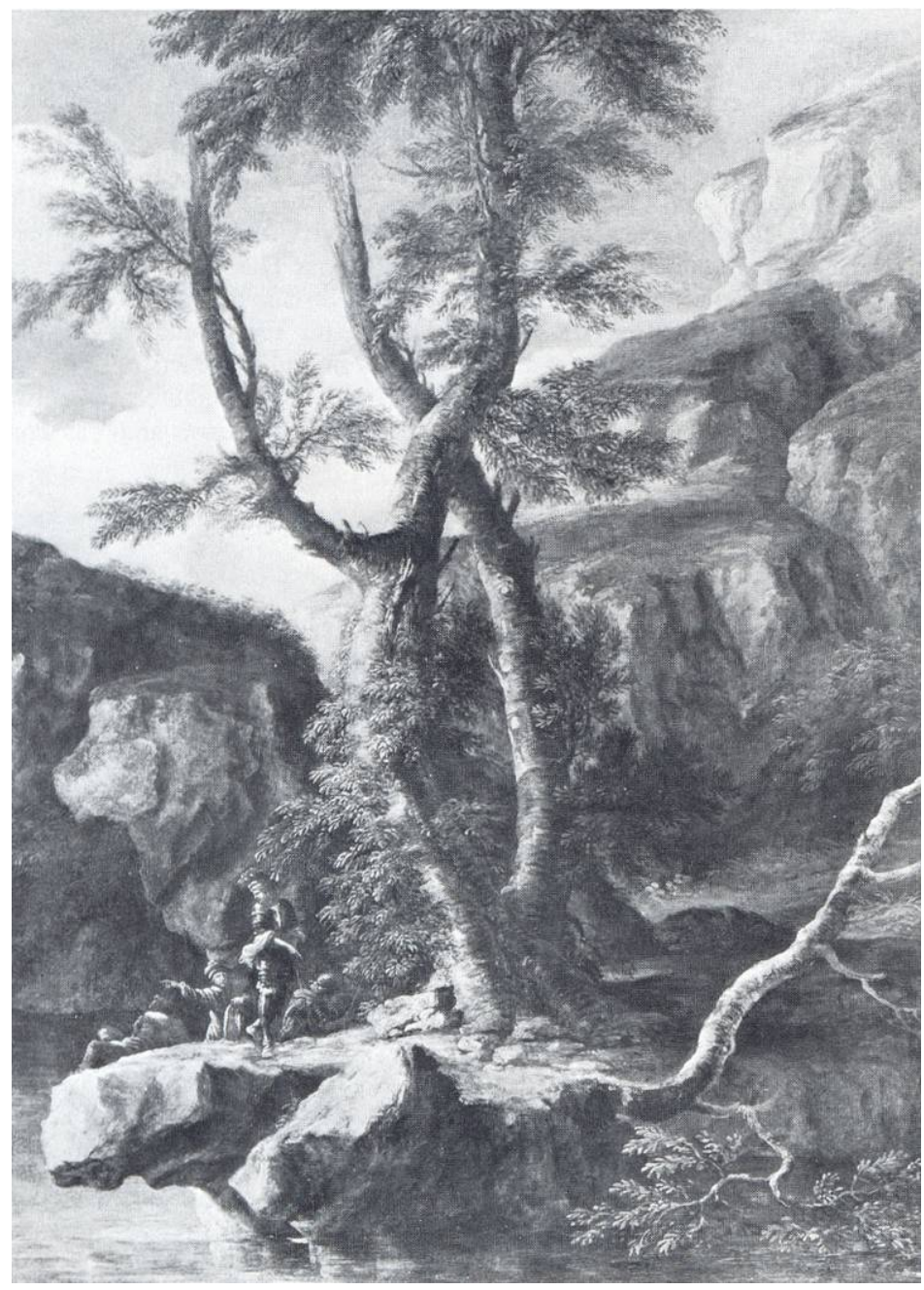

fig. 12 - Soldado e camponeses em paisagem rochosa, 1650 pintura de Salvatore Rosa 


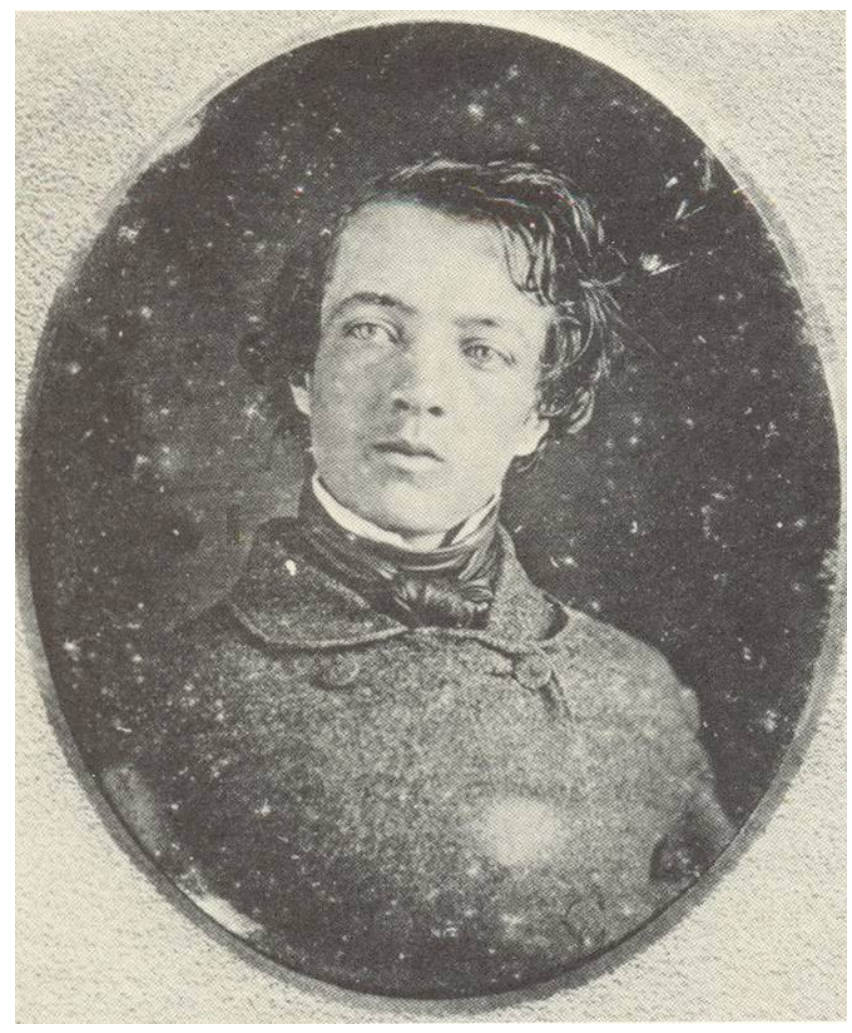

OLMSTED

IV 
Será preciso entendermos um dia, talvez um dia próximo, o que falta cima de tudo em nossas cidades: tranqüilos e amplos, espaçosos lugares para reflexão, lugares com longas e altas galerias pra o tempo ruim ou demasiado claro, aonde não chegue o barulho dos carros e dos pregoeiros, onde um refinado decoro proibisse até a um padre a reza em voz alta: construções e passeios que, no conjunto, exprimissem o que há de sublime no meditar e no pôr-se de lado ${ }^{1}$.

pequena introdução

Frederick Law Olmsted, (1822-1903) referirá John Ruskin, (1819-1900) e seus livros, em especial os que compõem os Modern Painters diversas vezes em sua vida 2. De fato, segundo o editor Charles Capen McLaughlin 3 os anos em que toma contato com essa literatura são um ponto de inflexão no percurso de Olmsted. O papel desempenhado por Frederick Law Olmsted, autor de escritos e projetos para os espaços livres da cidade interessa na medida em que seu percurso participa ativamente das definições, tanto da atividade profissional do que veio a se chamar Arquitetura da Paisagem, Landscape Architecture; quanto da fundação do próprio campo disciplinar que estuda e projeta a paisagem.

A intenção nesse capítulo é palmilhar parte de sua biografia apontando autores, lugares, referências e especialmente as dimensões estéticas e culturais que o levam a elaborar seus projetos, visualizando assim o universo de informações que compunha seu repertório. Esse recorte, estratégico, procura conformar relações que pretendem, ainda que por hipótese, ensaiar um nexo entre as origens do campo disciplinar e o Paisagismo atual.

\footnotetext{
1 NIETZSCHE, Friedrich. A Gaia Ciência. São Paulo : Companhia das Letras, 2002, p 190.

2 A biógrafa Laura Roper denomina Ruskin um dos mentores de Olmsted; em seu estóico escritório sempre houve uma fotografia de Ruskin na parede. In ROPER, Laura Wood, FLO, A Biography of Frederick Law Olmsted, The Johns Hopkins University Press : Baltimore \& London, 1983, (1973), p 72.

3 The Papers of Frederick Law Olmsted, volume I, The Formative Years(1822 - 1852); editor chefe: Charles Capen McLaughlin. The Johns Hopkins University Press : Baltimore \& London, 1977, p 225.
} 
A educação do jovem Olmsted não foi exemplarmente associada ao cânone, embora fosse filho de um comerciante abastado, John Olmsted, ele não seguirá os caminhos traçados pela educação formal da alfabetização à Universidade, passando por diversos lugares, diferentes tutores e experiências nem sempre felizes ${ }^{4}$. Por um lado essa prática de seu pai buscava pelo melhor modo de lidar com seus dois filhos do primeiro casamento, a mãe Charlotte falecera pouco tempo depois do nascimento do irmão John Hull Olmsted; o pai se casa novamente ${ }^{5}$ cerca de um ano depois.

Ao contrário do que se possa a princípio pensar da ação paterna, os filhos sempre foram bem vindos ao lar, e era permitido a ele perambular livremente pelos arredores de Hartford, visitando seus numerosos parentes que participam de sua formação; também as viagens de férias em família serão lembradas com apreço e detalhe. John Olmsted será uma figura paterna memorável, ele aparece nos livros como ponderado senhor que suportará financeiramente a família, sendo também, um dos principais responsáveis pelo despertar em seus filhos de um olhar atento em relação à natureza, por toda a vida objeto de suas viagens ${ }^{6}$.

Outra figura associada a sua formação, ao menos nesses anos iniciais é a de Jonathan Law, que se casara com a irmã mais velha da mãe Charlotte, e que lia os poetas latinos em voz alta para o jovem Frederick; essa experiência de poder inclusive manusear a biblioteca era acompanhada da oportunidade de cultivar partes do jardim. Suas leituras eram complementadas também na casa da avó, onde Olmsted tinha liberdade de investigar junto aos livros da biblioteca do avô, patriota convicto e amador das árvores. Data desse período as primeiras leituras de Izaak Walton; de Zimmermann, On Solitude; e de Uvedale Price, The Picturesque. Esse

\footnotetext{
4 Sobre John Olmsted, afirma Sutton:"Determinado que seu filho possuísse uma sólida e puritana base, que ele mesmo era incapaz de prover, envia seu filho a seis diferentes ministros de temperamento e inteligência variados". SUTTON, S. B. Civilizing American Cities. A Selection of Frederick Law Olmsted's Writings on City Landscapes. The MIT Press : Cambridge, Massachussets and London, England, $1971, \mathrm{p} 2$.

${ }^{5}$ Após a morte de Charlotte, em abril de 1827, John Olmsted casa com Mary Ann Bull. Cf. ROPER, op cit, p 5.

6 "Os Olmsteds realizam longas viagens em família, às vezes em transporte público ou barco, e frequentemente na carruagem da família, para as White Mountains, pela costa do Maine e pelo estado de Nova lorque. Eles se hospedavam em locais no interior ao longo do caminho e buscavam por vistas pinturescas descritas nos livros de escritores como Timothy Dwight e Benjamin Silliman. Embora fossem desarticulados sobre esses assuntos, os pais eram zelosos que suas crianças apreciassem as belezas da paisagem na qual elas encontravam a evidência da bondade de Deus". MCLAUGHLIN, op cit, p 5.
} 
tempo de descobertas é referenciado pela biblioteca do Instituto de Jovens de Hartfort, na qual encontra entre outros, o Forest Scenery de William Gilpin. Nesse mesmo Instituto participa de palestras com a proeminente intelectualidade de então, como Horace Bushnell e Ralph Waldo Emerson.

Contudo, as mazelas dessa educação pouco convencional na infância e adolescência acompanharão Olmsted por toda a vida, mas serão especialmente angustiosas nesses primeiros anos de busca nos quais alterna soluções para um futuro que vão do estudo precocemente frustrado de engenharia com o Sr. Frederick Barton; uma tentativa de formação como comerciante numa firma de importação em Nova York; até a decisão de aventurar-se no mar numa viagem, repleta de desconfortos e doenças, à China. Essas idas e vindas em busca de uma vocação que pudesse dar-Ihe condições, segundo as palavras de seu próprio pai 7 de participar do grande teatro da vida, parecem começar a se resolver apenas a partir de 1844, quando retorna da viagem a bordo do Robinson ao Oriente.

A idéia de que seu futuro estivesse ligado à terra faz com que inicie nova série de investidas em sua formação. Como fazendeiro ele precisava de treino e para isso em outubro de 1844, com 22 anos, vai viver com David Brookses em Cheshire, Connecticut, de modo a aprender o que pudesse da profissão. Relê, uma vez mais, On Solitude de Zimmermann, que entusiasticamente desejaria que todos conhecessem ${ }^{8}$.

Em março de 1845 está novamente em casa paterna à procura de novo lugar para trabalhar e aprender; o contato vem por um colega do irmão John, Frederick J. Kingsbury, que o indica para um fazendeiro de sucesso em Waterbury, Connecticut, Joseph Welton. Nesse momento de sua vida, possivelmente instado pelo irmão, que como ele não segue com afinco os estudos em Yale onde fora admitido em 1842, Olmsted escreve sobre as vantagens que acredita existir na vida como agricultor. Para ele, tratava-se de uma vida simples e respeitável, uma prática que se atualizava com a investigação e conhecimento científico; enfim, uma profissão congênita, singularmente pacífica ao espírito, distante das invejas e rivalidades tão presentes nas outras ${ }^{9}$.

\footnotetext{
7 ROPER, op cit, $\mathrm{p} 15$.

8 OLMSTED apud ROPER, op cit, p 35.

${ }^{9}$ Carta de Frederick ao irmão John de 23 de junho de 1845. OLMSTED apud, ROPER, op cit, p 37.
} 
No outono de 1845 Frederick Law Olmsted vai ficar com o irmão em Yale. Lá, como ouvinte, tem oportunidade de participar de aulas de Benjamin Silliman sobre agricultura científica, bem como química, mineralogia e geologia. Entretanto, é outra qualidade de encontro que marcará essa passagem por New Haven. Olmsted costumava troçar de sua formação afirmando ser ele nada mais que um grosseiro 10; uma especial senhorita terá um papel decisivo na nova percepção que o futuro arquiteto da paisagem terá de si mesmo: Elizabeth Baldwin ${ }^{11}$ afirmaria que a suposta falha em sua educação não deveria evitar que ele se tornasse um homem culto; é graças a sua influência, afirmaria Olmsted, que viria a ler Emerson, Lowell, Ruskin e outros reais profetas. Esses autores fariam com que Olmsted acreditasse na possibilidade de seu refinamento poético e mesmo na peculiaridade de sua constituição de gostos.

Em finais de 1846, John Olmsted adquire para o filho Frederick Law Olmsted, em Sachem, uma pequena fazenda. 0 período imediatamente anterior é passado junto de outra propriedade modelo, Fairmont, para que ganhasse confiança em suas habilidades como fazendeiro. Dessa vez a indicação para que trabalhasse junto a George Gueddes veio pelo editor do Cultivator, Luther Tucker. No período que passa em Fairmont, as leituras transitam entre a Bíblia e seus Salmos, um livro de autoria de Thomas Upham, Principles of the Interior or Hidden Life e a declarada intoxicação por que passa sob a influência de Sartor Resartus, de autoria de Thomas Carlyle 12 .

Na ocasião em que Olmsted estivera no escritório de Luther Tucker, ele encontrara Andrew Jackson Downing, landscape gardener, jardineiro da paisagem, já famoso pela publicação de seu livro A Treatise on the Theory and Practice of Landscape Gardening Adapted to North America; primeiro livro a discutir o arranjo e a conexão entre

\footnotetext{
10 ROPER, op cit, p 40.

11 Elizabeth era filha do advogado, abolicionista e governador Roger Sherman Baldwin; ela, a partir principalmente de Emerson e Lowell, parece convencer Olmsted de que as idéias que possui vêm de sua educação informal e são respeitáveis e dignas de mérito; em carta a Elizabeth, muitos anos após terem deixado de se ver, em 1890, Olmsted assevera ser ela responsável pela sua descoberta de que sua educação não seria um obstáculo para uma vida intelectual, como habitualmente supunha..Cf. MCLAUGHLIN, op cit, p 66.

12 I do think Carlisle,(sic), is the greatest genius in the world. OLMSTED apud ROPER, op cit, p 45.
} 
as arquiteturas e o entorno das propriedades, o que o transformou num reconhecido árbitro nas questões de gosto rural ${ }^{13}$.

Contudo, esse período de aparente brilho na condução de sua formação parecerá viver um ocaso no tempo em que Olmsted se dedica à nova propriedade em Sachem. Quando o irmão John o visita, em maio de 1847, encontra um homem que parece haver esquecido o quanto mais amplo pode ser o contato com a Natureza: não há companhias apropriadas, nenhum vizinho com quem estabelecer uma conversação mais elaborada; Frederick fala apenas com os homens que para ele trabalham e o assunto é plantar, colher e fertilizar, sem trâmites poéticos.

Ele por certo continuava a pensar grandes pensamentos, acreditava o irmão, tornava-se mais e mais transcendental a cada dia 14; mas Frederick parecia ter escolhido atolar seus planos de tornar-se um cidadão exemplar, o que implicaria numa ação que incluía trabalhar para seu país e concidadãos, num lugar que não ofereceria contraparte ao seu gênio. O fato é que em 1848 os irmãos Olmsted partem para Staten Island à procura de novas terras, dessa vez propriedade mais produtiva, em termos físico-naturais, bem como culturais.

O verão de 1848 será passado na nova propriedade de Frederick, que agora possui uma casa de nove quartos e pode abrigar o patriarca John e toda a família. As melhorias que Olmsted imprime à casa e entorno são simples mas marcantes; nos três anos que passa nessa terra planta grande variedade de árvores ornamentais, projeta um novo acesso por gracioso caminho em curva para a casa principal, propondo nova localização dos celeiros que estavam muito próximos dela. Os vizinhos promovem vida social e os mais próximos são os Perkins: o doutor Cyrus Perkins, é possuidor de notável biblioteca e tem, entre seus quadros e gravuras, um original de Salvatore Rosa. Os Perkins são avós de Mary, que perdera os pais na infância e vive com os avós em ambiente letrado. Mary Perkins e John Olmsted, o irmão, estarão sob o domínio de Ruskin no verão seguinte: em julho de1849, John lê Ruskin em voz alta para Mary, que será sua futura esposa, enquanto observa sua admiração

13 ROPER, op cit, p 44

14 OLMSTED, John Hull, carta à Collins de 8 de dezembro de 1847. Apud ROPER, op cit, p 44. 
acerca da finalidade da vida do homem: A função e utilidade do homem (...) é ser testemunha da glória de Deus, e antecipar essa glória pela obediência prenhe de razão e a felicidade que resulta disso ${ }^{15}$.

A indicação da leitura viera possivelmente pelo próprio Olmsted que em carta de 10 de fevereiro de 1849 relata sua intensa satisfação de ler em voz alta Modern Painters 16 com sua amiga, e uma das poucas pessoas com quem afirma poder falar em termos estéticos, Sophia Candence Stevens.

Nos finais de semana, o amigo em comum dos irmãos, companheiro de John em Yale, Charles Brace, ocasionalmente visita a fazenda e faz leituras em voz alta da obra de Ralph Emerson. É essa atmosfera que impregna o discurso de Frederick Law Olmsted quando procura organizar uma sociedade agrícola para Richmond County, no discurso Appel to the Citizens of State Island, 1850, ele reverbera tons da obra de Emerson, Nature: Addresses and Lectures. Argumenta que uma sociedade por si traz vantagens práticas como a difusão de conhecimento científico, introdução de novos métodos agrícolas, melhorias nos transportes e variedade nas espécies vegetais, bem como na arquitetura doméstica e no gosto rural. 0 movimento seguinte de sua fala estabelece o objetivo maior ao fazer do membro dessa sociedade alguém preocupado com as questões éticas e morais: ...com o fazendeiro deve erguer-se o Homem. Os mistérios de Deus estão sempre revelados à observação. (...) Nós devemos cultivar mutuamente o verdadeiro gosto, e seus frutos amadurecerão não apenas para agradar seus olhos pelo embelezamento de nossa região, mas nutrirão nossos corações com tudo que é verdadeiro e bom ${ }^{17}$.

De abril a outubro do ano de 1850, Olmsted deixa sua propriedade e a liderança da sociedade e parte com o irmão John e o amigo Charles para uma temporada em Londres. O que havia sido visto nos livros seria agora objeto de experiência.

15 RUSKIN apud ROPER, p 61.

16 “Modern Painters aperfeiçoa o entendimento e Miss Stevens forma um amálgama com ele em meu coração..." OLMSTED apud MCLAUGHLIN, op cit, p 91. Sophia Candence Stevens foi professora em Hartford High School de 1848 a 1851, casa-se em 1851 com Stephen Hitchkock.

17 OLMSTED apud MCLAUGHLIN, op cit, p 333. 
A carta de 29 de fevereiro de 1850 mostra um Olmsted que procura obter a permissão do pai para deixar a fazenda e juntar-se ao irmão e amigo naquilo que the parece ser uma oportunidade única. Sua argumentação enumera prós e contras asseverando que essa é a melhor alternativa para a continuidade de sua formação e para o próprio desenvolvimento da fazenda num negócio rentável: Por favor, some o dinheiro perdido em minha ausência, e o compare com o valor de minha experiência entre os fazendeiros ingleses e escoceses. 0 modo pelo qual eu tenho gerenciado essa fazenda certamente mostra que eu não faço pouco de sua aplicação 18.

É verdade que Frederick Law Olmsted vem transformando a lida da fazenda, sistematizando o trabalho: ordens são dadas aos homens contratados; elas devem ser estritamente seguidas e reportadas pelo gerente ao final do dia, quando ele recebe novas instruções ${ }^{19}$. A organização se expressa não só pela cadeia hierárquica, mas vai da organização das ferramentas, que retornam ao lugar de origem no término da jornada, ao aspecto geral da propriedade, que, no entanto, ainda não era um modelo de produtividade. Seja pela confiança que vem ganhando desse pai que, de fato, acredita ser a viagem um contato relevante; seja porque esse mesmo pai não Ihe possa negar a real oportunidade de estar entre amigos, ele lhe dá a permissão a fazer tal visita aos cenários pinturescos que ele mesmo perseguia.

O cenário da Inglaterra rural seria um deleite constante, suas observações que incluem freqüentes percepções sobre os estados da atmosfera, as nuvens, as questões relacionadas a toda sorte de combinações e objetos de experiência na paisagem, estão gravadas em seus escritos; porém a relação mais fundamental, aquela que unirá a paisagem à elevação das condições de vida das classes menos abastadas estão apenas iniciando sua convergência. Esse contato tornar-se-á a força de sua argumentação em prol dos parques públicos nas cidades.

O parque de Birkenhead projetado por Joseph Paxton foi para ele como uma revelação 20.

\footnotetext{
18 OLMSTED, apud MCLAUGHLIN, op cit, p 340.

19 ROPER, op cit, p 60.

20 ROPER, op cit, pp 70 e 71 .
} 


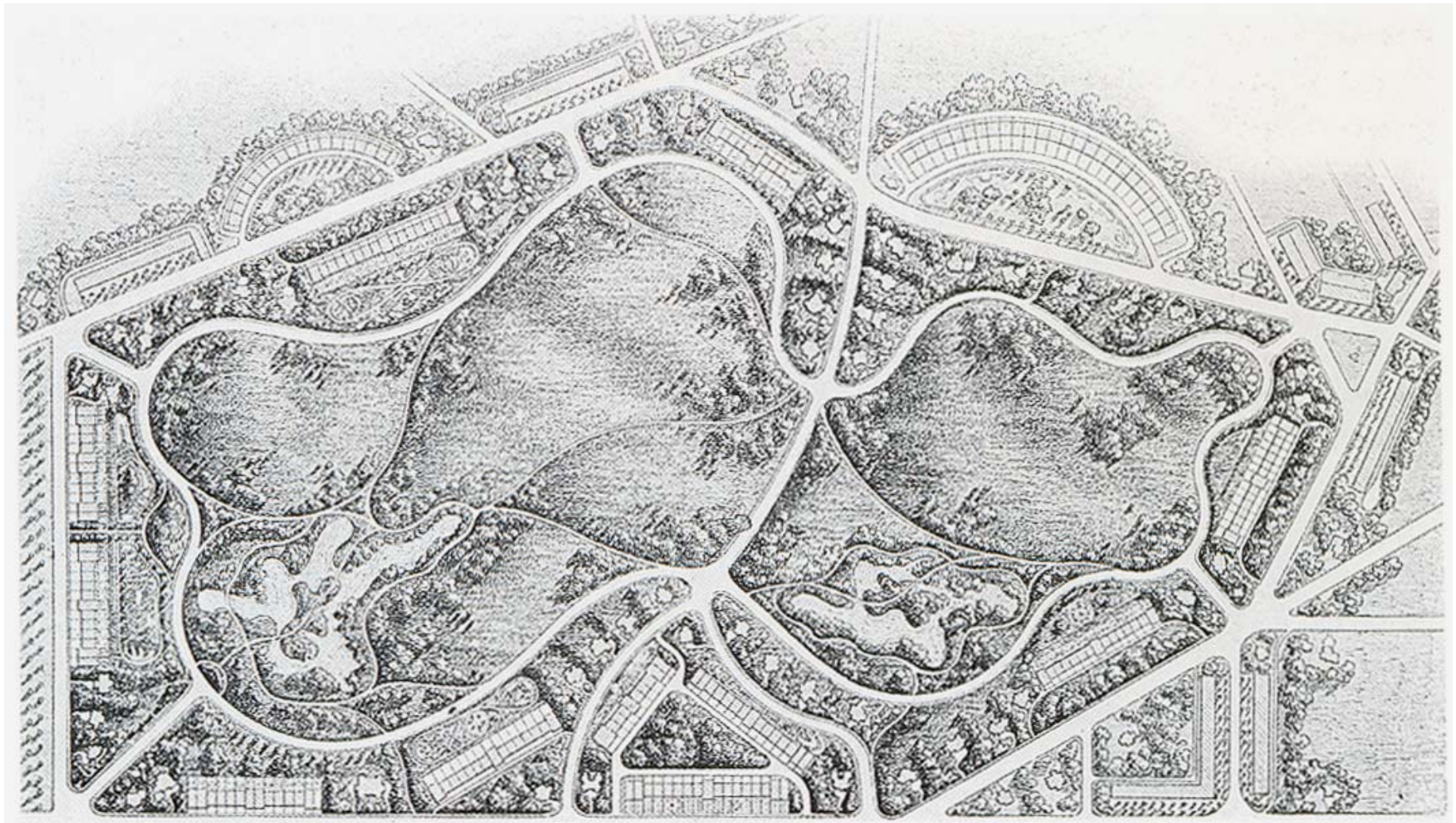

fig. 13 - Birkenhead Park próximo de Liverpool, 1843

Não passa despercebido à Olmsted que a empreitada traz acúmulos financeiros, os lotes lindeiros tem entradas particulares para o parque; as ruas que partem do espaço livre também foram objeto de projeto, e descrevem um arranjo de lotes que imprime qualidade à ocupação. Os 20 acres de original terra plana tiveram seu relevo modelado graças à terra obtida da escavação de um lago para o lugar, todo ele acessível por rodas, ou a pé. Porém não é no privilégio de poucos lotes que Olmsted tem sua atenção cativa: era a existência de um lugar como aquele na cidade que punha sua reflexão e sensibilidade em movimento. 
Dos parques que ainda não são públicos referencia o Eaton Park em Chester, sua fala elogiosa dirige-se apenas ao autor da obra ${ }^{21}$, em retórica apóstrofe: Que artista, tão nobre, tem sempre estado em meu pensamento, como aquele que com a mais alta concepção de beleza e poder de projeto, desenha uma linha, inscreve as cores e dirige as sombras de uma pintura tão grande que a Natureza deverá ocupar-se por gerações, antes que o trabalho que ele previra para ela realize seus intentos.

No caminho percorrido quase todo ele a pé entre Liverpool e Londres 22 fora testemunha de habitações bastante pobres e cortiços, uma massa morta de pura pobreza ${ }^{23}$. 0 contraponto entre essas imagens e as dos parques faz crescer a convicção de que esses espaços são necessários para civilizar a vida urbana; e mais, que a experiência artística passível de ser vivenciada nesses lugares só tem verdadeiro sentido se tornada pública; a beleza, repercutindo Ruskin e seus outros profetas, não pode ser dissociada de sua utilidade social.

Nos finais de 1850, já de volta à sua fazenda, coleta as cartas e manuscritos que escrevera sobre a viagem e procura dar-Ihes uma forma literária que fosse atraente ao homem comum; isso significava uma estratégia que pretendia lançar mão de sugestões e idéias relacionadas ao gosto que não apareceriam de modo direto. Esse expediente foi encorajado pelo vizinho e amigo George Putnam, considerado um dos editores mais liberais de Nova lorque; seria sua a idéia de lançar livros de qualidade literária a preços baixos em edições sem luxo, mas integrais e em grandes tiragens. Começa sua inovação com uma seleção de Charles Dickens, depois publica um volume de Thomas Hood, e o batizado Walks and Talks of an American Farmer in England, de Frederick Law Olmsted, que não é um sucesso de vendas, mas é recomendado pela crítica contemporânea como admirável observação de uma sociedade.

Esse processo vai fazendo com que o fazendeiro ceda lugar ao escritor; o período imediato à chegada da Inglaterra mostrara a Olmsted que a vida no campo não guardava todas as emoções que seu espírito parecia

21 OLMSTED, Frederick Law. Walks and Talks of an American Farmer in England. New York : Putnam, 1852, apud ROPER, op cit, p 71. A biógrafa Laura Roper assinala que não parece haver confirmação de que Olmsted esteja alerta para o fato de que é a Capability Brown que seus elogios se dirigem.

22 Segundo a cronologia presente no apêndice do $1^{\circ}$. Volume do The Papers of Frederick Law Olmsted o percurso é trilhado entre 27 de maio a 21 de junho de 1850. MCLAUGHLIN, op cit, p 394.

23 OLMSTED, Frederick Law. Walks and Talks of an American Farmer in England, apud ROPER, op cit, p 70. 
querer viver ${ }^{24}$. Os acontecimentos, se não o tornam um escritor de sucesso, ao menos o colocam em contato com uma parte da sociedade que o interessava, e que será sempre de grande valia nas empreitadas com as quais se envolveu a partir de então.

Entre 1851 e 1852 Andrew Downing publicará seus artigos, sobre o Birkenhead Park e sobre o cultivo de frutas na Inglaterra no periódico Horticulturist. Olmsted, leitor de Downing, no Horticulturist e de Bryants, editor do New York Evening Post, mantém-se ao lado daqueles que acreditam na necessidade de guardar uma parte do espaço livre de edificações da cidade de Nova lorque para um parque. Downing virá a falecer em acidente náutico no rio Hudson em julho de 1852, antes que a comissão desse início aos trabalhos de construção do Central Park; o segundo volume do Walks and Talks of an American Farmer in England será dedicado a ele.

\section{um período no sul do país e a configuração de uma nova atividade}

A publicação do livro e a indicação do amigo Charles Brace fazem com que Olmsted seja convidado pelo editor do The New York Times, ainda em 1852, para que realizasse uma reportagem abrangente acerca das condições, sociais, econômicas e culturais, do Sul dos Estados Unidos ${ }^{25}$. Seu método de reportagem foi bastante similar ao do livro Walks and Talks: ele apresentava uma realidade concreta e rica de detalhes para que o leitor pudesse desenvolver uma opinião sobre a questão, em seguida ele oferecia a sua própria. Observador incansável, ele descrevia a maneira pela qual as pessoas falavam, como se vestiam, as construções e mobília das casa e hotéis

\footnotetext{
${ }^{24}$ A viagem causara intensa impressão ao seu espírito, a rotina da fazenda e as pessoas o entediavam, como atesta a carta enviada a Charles Brace em 12 de novembro de 1850: "Estou muito satisfeito em ouvir notícias suas de Hamburgo. Gostaria de estar com você. Eu o aconselho a ficar o maior tempo que conseguir. o fato é que quando nós estávamos viajando, estávamos vivendo muito mais, tendo muito mais do mundo, e alcançando muito mais. Todos por aqui parecem superficiais, frívolos absorvidos em uma maré de espuma, gás e bolhas". OLMSTED, apud MCLAUGHLIN, op cit, p 358.

25 Aparentemente seu estilo incomodou aos editores, mas a audiência se sentiu tocada pela fala de Olmsted, o que garantiu a continuidade de sua participação e publicação. Cf. SUTTON, op cit, p 5.
} 
que visitava e se hospedava; as plantações e modo de cultivo, das marginais às padrões, antigas e modernas; as estradas, as estradas de ferro, as características dessa parte do país pela qual viajava ${ }^{26}$.

A idéia da série fora de Henry Raymond, editor e um dos fundadores do New York Times e tinha como horizonte municiar a campanha abolicionista, contudo Olmsted não se mostra um adepto da idéia a princípio. Fiel à natureza de sua empreitada, constrói a cada artigo aquilo que parece ser uma sólida argumentação sobre o assunto, que nasce de dados práticos como valores: dos empregados e dos lucros obtidos em propriedades com esse tipo de sistema, para declará-los ao final como dispendiosos e perdulários. De início, ele fora reticente acerca das características e capacidades naturais dos negros ${ }^{27}$, porém as experiências pelas quais passa revelam não uma raça inferior, mas escravizada, é o medo que opera em seus espíritos, não a curiosidade, ou a vontade de desenvolver suas capacidades 28 .

A inversão do argumento é trunfo olmstediano: a não elevação da situação da raça negra é desmoralizante para a branca. A situação dos Estados sulinos é a expressão de um domínio branco pouco ambicioso e indolente; péssimas estradas, casas desconfortáveis, comida monótona e pobre, tudo testemunha a indiferença. A conclusão aparece nos jornais do dia 13 de fevereiro de 1854 e afirma ser a escravidão um desserviço à economia, um erro moral e uma desastrosa deficiência para negros e brancos 29.

As viagens de Olmsted para o Sul desencantaram-no definitivamente da vida rural. Embora ele tenha ficado com a propriedade da fazenda até 1860, passa sua gestão a partir de 1855 para o irmão que retornara da Europa, casado com Mary Perkins, com filhos, e ainda sem melhora significativa em sua saúde.

Entre 1855 e 1856 ele se junta a dois conhecidos, Joshua Dix e Arthur Edwards na publicação do periódico mensal Putnam's Magazine. Seu pai Ihe empresta o capital necessário para a sociedade: cinco mil dólares.

\footnotetext{
${ }^{26}$ Seus artigos foram publicados sob o título de Yeoman e estrearam no New York Times em fevereiro de 1853. Cf. ROPER, op cit, p 86.

27 ROPER, op cit, p 87.

28 Tratar um homem como escravo, ou afirmar sua incapacidade de ser livre é reduzi-lo '...a um corpo de homem, movido apenas pela força externa, agindo pelo medo; uma alma sem responsabilidade'. OLMSTED, Frederick Law. Yeoman in New York Times, 30 de junho de 1853 . Apud ROPER, op cit, $\mathrm{p} 88$.

29 ROPER, op cit, p 89.
} 
Olmsted acumula cargos que vão da edição da publicação ao responder de cartas, o livro concebido a partir dos artigos sobre o Sul, Journey in the Seaboard Slave States, é editado pela Dix \& Edwards; porém toda essa atividade não evitaria que o negócio fosse à falência. Antes disso, Olmsted tentaria uma última cartada, viajando junto da irmã para a Europa ele vai visitar editores para tentar algumas trocas; em fevereiro de 1856 parte para Londres, sua primeira parada. 0 tour é intenso e inclui França, Itália, as cidades de Praga e Leipzig. Contudo, o que aparece como grande experiência nessa viagem é a paisagem da Itália, cujos jardins eram muito mais refinados do que ele esperava, vegetados interessantemente e constituídos sob princípio novos para ele. (...) ele os estudou com os olhos e a mente de modo a reter para o resto de sua vida profissional as impressões e informações que então alcançou 30 .

A firma falida, o irmão uma vez mais indo para a Europa adoentado; é o acaso que brinda Olmsted quando ele encontra um dos participantes da Comissão de construção do Central Park.

\section{uma atividade sob medida}

O encontro põe Olmsted a par da próxima reunião que escolherá o superintendente de obras do futuro parque; o superintendente é chefe de trabalhos e, principalmente, o responsável por fazer valer as regras governamentais de uso público do parque. Em 1857, munido de cartas de recomendação ele consegue a indicação para ser o Superintendente do Central Park na Cidade de New York ${ }^{31 .}$

Seu apreço pelos parques tinha se desenvolvido a partir da viagem para Londres, embora já compartilhasse de sua defesa antes disso. Birkenhead Park, próximo a Liverpool, era um símbolo; mas muitas outras cidades na Europa, mesmo as que não haviam chegado à república, forma mais apropriada ao homem livre, como França e Alemanha, já tinham assegurado o pedaço de grama e céu aos seus concidadãos. A argumentação de Olmsted

30 ROPER, op cit, p 114.

31 SUTTON, op cit, p 7. 
procura firmar o parque para além da moda, dentro do território da necessidade, da natural necessidade ${ }^{32}$; ao mesmo tempo defende ser essa necessidade algo que cabe ao poder municipal suprir.

A reserva de terra para a construção do parque foi preocupação constante de homens como William Cullen Bryant, que publica no New York Evening Post o primeiro editorial sobre o tema em 1844. Apenas em 1853 a câmara legislativa do Estado de Nova lorque autorizará a cidade a adquirir um espaço central para a edificação do primeiro parque dos Estados Unidos, com dimensões suficientes para abrigar o que Downing chamava de fino parque rural. A fala de Downing, como a proferida no artigo A Talk about Public Parks and Gardens de outubro de 1848, repercutia um movimento em favor dos parques que começava a firmar-se nos Estados Unidos que se inicia por volta dos anos de 184033.

São muitas as estórias que povoam a conquista dessa grande porção de terra, e da luta, da qual participará ativamente Olmsted, para salvaguardá-la em sua totalidade e uso predominante ${ }^{34}$.

Em grandes tintas pode-se contar algumas delas com o propósito de fazer conhecer melhor o contexto em que se move Olmsted em meados do século XIX, ao mesmo tempo em que se revelam suas referências artísticas e sócio-culturais.

O parque já possuía um primeiro plano desde 1853, de autoria de Egberg Viele, engenheiro com especialização sanitária que havia preparado às suas expensas um primeiro levantamento topográfico e um plano geral. Em 1856, a comissão adota seu plano e o contrata como engenheiro chefe ${ }^{35}$. Quando Olmsted se torna

\footnotetext{
32 OLMSTED, Jr. \& KIMBALL, Theodora, editors. Forty Years of Landscape Architecture: Being the Professional Papers of Frederick Law Olmsted, senior - Landscape Architect, 1822-1903. Volume 2: Central Park as a Work of Art and as a Great Municipal Enterprise, 1853-1895. New York and London : G.O.Putnam's sons / The Knickerboker Press, 1928, p 14. Esse volume oferece, segundo seus idealizadores, a concepção do parque como a idealizou Olmsted e se inicia com um balanço sobre o tema dos parques.

${ }_{33} \mathrm{O}$ artigo é publicado na Horticulturist num tempo em que Nova lorque já conta com meio milhão de habitantes. Cf. DAL CO, Francesco et alii. De los Parques a la región. Ideologia progressista y reforma de la ciudad americana. In La Ciudad Americana, da guerra civil ao New Deal. Barcelona : Gustavo Gili, 1975.

34 "O parque era então, como ainda segue sendo, vulnerável às mazelas políticas e um dos milagres ocorridos é que um plano de qualidade superior foi escolhido, executado e permanece na sua maior parte, intacto". SUTTON, op cit, p 8.

35 OLMSTED, Jr. \& KIMBALL, op cit, pp 31 e 32.
} 
superintendente em setembro de 1857, encontra um ambiente hostil 36; para completar um ano de angústias e desafios, o irmão, John Hull Olmsted, falece na Europa em 24 de novembro do mesmo ano.

\section{a premiação}

Olmsted tem uma rotina bastante extenuante no trabalho quando Calvert Vaux o convida a colaborar no projeto do parque que participaria da competição que a Comissão do mesmo decidira empreender. Como superintendente Olmsted auxiliava o Engenheiro chefe na execução das tarefas, e também funcionava como os olhos e ouvidos da Comissão no que diz respeito ao cumprir de suas ordens 37.

O plano de Olmsted e Vaux, chamado Greensward, foi elaborado às noites e finais de semana do inverno de 1858, entregue no último dia e escolhido entre 32 outras proposições ${ }^{38}$.

Uma de suas principais qualidades era trazer beleza a um território sabidamente desprovido de belezas naturais marcantes, um trabalho no qual arte e técnica procuravam construir uma paisagem memorável. Eles conquistavam essa beleza através de refinadas estratégias técnicas, ajustando todo o trabalho ao resto da cidade, numa congruência até então nunca esboçada 39.

Calvert Vaux nascera em Londres dois anos depois de Frederick Olmsted. Graduado na Merchant-Tailors School e aprendiz em escritório renomado de arquitetura, Vaux encontra Andrew Downing no verão de 1850 em

\footnotetext{
36"Nada em seu currículo - um fazendeiro que não fez sua fazenda produtiva, um escritor que não tinha nada, exceto reputação, um editor que foi à bancarrota - sugeria suas capacidades". ROPER, op cit, p 130.

37 OLMSTED, Jr. \& KIMBALL, op cit, p 37.

38"As regras da competição especificavam que os planos deveriam promover certas características: ao menos quatro ligações diretas leste oeste entre as ruas 59 e 106, um local para paradas de 20 a 40 acres, três playgrounds de três a dez acres cada, um lugar para exibições, ou concertos, um lugar para uma fonte ornamental e um para um mirante, um jardim de flores de dois a três acres, bem como um lugar que pudesse ser cheio de água para que, congelado, funcionasse como local de patinação. OLMSTED em carta ao pai, John, de 14 de janeiro de 1858. Apud ROPER, op cit, p 136.

39 "O Parque é um trabalho de arte único e como tal, objeto de uma lei primeira que rege todo trabalho de arte, a saber, que ele seja forjado sob um único e nobre motivo ao qual o desenho de todas as suas partes, mais ou menos de modo sutil, devem confluir e concorrer". OLMSTED apud OLMSTED Jr. \& KIMBALL, p vi. e SCHAMA, op cit, p 569.
} 
Londres, que o convence a vir para a América trabalhar. Sócios, herda o negócio quando Downing falece, mudando para Nova lorque em 1857.

Olmsted e Vaux explicam suas intenções de criar no novo parque um contraste nos percursos; uma variação nos cenários que procuraria sugerir à imaginação grande espectro de condições rurais (sic). A questão social na perspectiva de Olmsted tem a mesma valoração que a artística, uma vez mais referendando a questão lançada por Ruskin de que não havia como dissociar a beleza da função social: o parque deveria ser aberto a toda população, sua experiência tinha dimensões pedagógicas e formativas, e a qualidade do uso, um assunto sujeito a estratégias tão elaboradas quanto as da arte ${ }^{40}$.

A descrição do plano afirma poder considerar a partir do lugar uma distinta divisão em duas porções que serão chamadas, convenientemente, de upper e lower parks, parque de cima e parque de baixo. 0 upper park tem as linhas do horizonte mais nítidas e extensas; suas declividades são amplas sob qualquer ponto de vista e essa unidade deve, segundo os autores da proposta, ser estudada e preservada em seus detalhes. Como essa característica é o mais elevado ideal que pode ser alcançado num parque, sob quaisquer circunstâncias, e é o

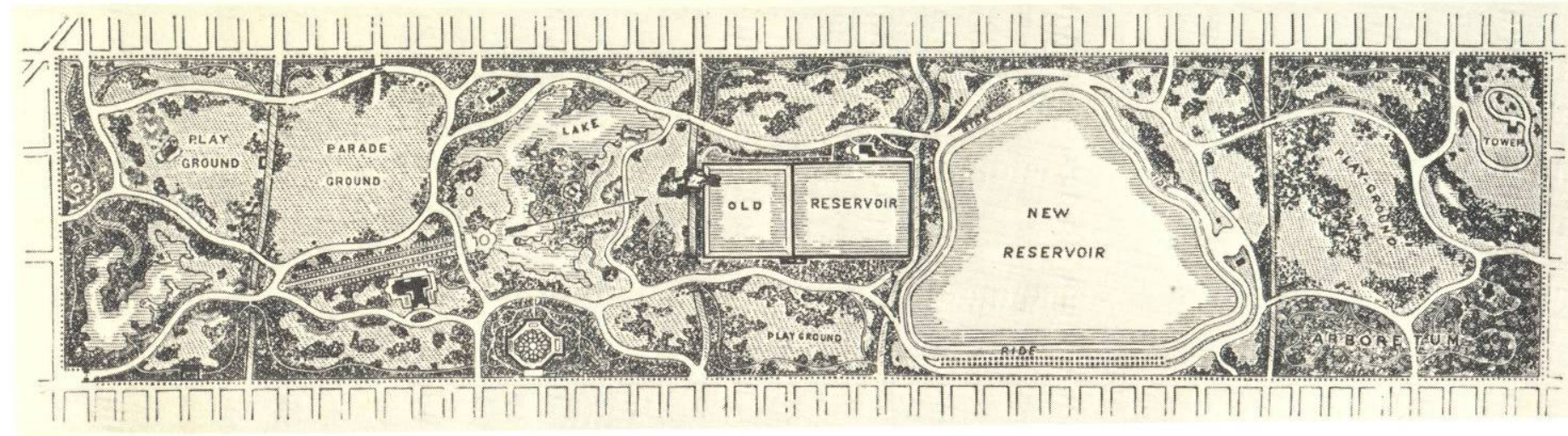

fig. 14 - Central Park, à esquerda Lower Park, à direita Upper Park

400 parque tinha seus limites claramente definidos e toda sua extensão tratada de modo que não podia escapar à percepção que mesmo os lugares que ainda não haviam recebido melhorias eram distintos do entorno de terras livres, e deveriam ser utilizado diferentemente. Conforme o projeto foi sendo implantado, e uma parte após a outra foi aberta à utilização, o papel dos guarda-parques foi fundamental para criar o espírito de uso comum e civilizado que seus arquitetos defendiam. A política para sua manutenção foi objeto de extensa argumentação por parte de Olmsted, que selecionava as pessoas e as treinava. Cf. ROPER, nota 14 p 145; e OLMSTED apud OLMSTED Jr \& KIMBALL, op cit, pp 58 a 61. 
mais decisivo contraste às confinadas e formais linhas da cidade, é desejável, interferir nela, com ruas que Ihe atravessam e outras construções, o menos possivel ${ }^{41}$.

O lower park possui uma heterogeneidade que demanda um tratamento muito mais particularizado, não há uma característica ou feição predominante que guie o projeto nessa parte do território. A mais importante qualidade de sua variada fisionomia é a encosta rochosa e arborizada, imediatamente ao sul do Reservatório: Visto que além desse ponto não parece existir nenhuma característica natural de importância que opere como direcionador da intervenção no cenário, será importante desenhá-la com a maior atenção possível de modo a prover os meios de descanso e lazer contemplativo propiciando vistas naturais e tornando a lateral que limita 0 parque e suas vizinhanças, tão pouco evidentes quanto possível.

As instruções do concurso pediam por quatro ruas que atravessassem o parque de lado a lado no sentido lesteoeste, os arquitetos baseiam-se em exemplos do exterior para criticar o modo pelo qual essas ruas se apresentam, por exemplo, no Regent's Park em Londres, onde as ruas cindem o parque e, principalmente, a paisagem. A engenhosa técnica proposta foi a atualização do haha de Humpry Repton, que já havia entrado na cidade através da releitura que fazem dele os projetos de alguns Boulevards ${ }^{42}$. Esse estratagema que busca a continuidade da paisagem e sua variação sem o limite explicitado, manterá o tráfego de carros separado dos caminhos de pedestre, tornando as ruas que cruzam o parque pouco perceptíveis; mesmo as ruas para as carruagens e o pedestres são diligentemente separadas e o cruzamento desses caminhos tratados com esmero de desenho em suas pontes e passagens.

41 OLMSTED, Frederick Law. Description of Plan for the Improvement of the Central Park. In The Papers of Frederick Law Olmsted, Volume III, Creating Central Park, (1857-1861). McLAUGHLIN, Charles Capen, editor chefe. The John Hopkins University Press : Baltimore and London, 1983, p 119.

42"Em muitas vezes, de modo a não interromper as aléias, as ruas que os cruzam, (aos Boulevards), são realizadas em forma de passadiços, levados a cabo através de altos arcos. (...). No plano oferecido à Comissão, cada rua transversal será rebaixada em relação à superfície geral, de sorte que em toda intersecção com os caminhos do parque, estes estejam elevados sobre aqueles, sem qualquer óbvia divergência em suas mais atrativas rotas". OLMSTED apud McLAUGHLIN, op cit, p 122. 
Ponto a ponto o projeto apresenta sua interpretação das regras dispostas pela Comissão e suas alternativas de projeto, das quais se ressaltam algumas que parecem ser de especial importância para os propósitos desse trabalho.

Ao descrever a entrada pela $5^{\text {a }}$. Avenida, os autores afirmam ser essa a mais bela aproximação da cidade, contudo sua declividade por demais abrupta poderia comprometer a percepção artística da paisagem da chegada. 0 caminho dessa entrada é projetado de modo que se visualize uma grande massa rochosa que oferece características naturais suficientes para ocupar a atenção. Outro pequeno morro de pedras dentro de curta distância dirige o visitante ao centro do parque. Isso pode ser facilmente alcançado graças a uma pequena elevação do terreno intermediário; na extensão, à direita, a conformação natural oferece um fácil acesso diretamente conectado com amplo platô que ocupa o centro da metade baixa do parque 43 .

Embora se declarem avessos de modo geral ao princípio simétrico de arranjo das árvores, os arquitetos afirmam considerar que uma característica essencial de um grande parque metropolitano é que ele possua uma Promenade; um passeio cujo projeto está referenciado na tradição e se apresenta nivelado, amplo, inteiramente sombreado, e cuja extensão é suficiente para uma boa caminhada. Esse caminho desenha-se como uma grande regularidade em meio a um desenho irregular, seu comprimento cria um eixo que visualiza o que se chamou de Vista Rock, o mais proeminente ponto da paisagem de lower park. 0 argumento dos autores acerca de uma possivel crítica sobre essa opção de projeto apresenta a variação como figura fundamental do pinturesco; a topografia da área do parque é tão variada, tão sugestiva do tratamento natural, que a regularidade participa desse cenário eminentemente pinturesco como explícito artifício; essa avenida deve ser considerada como aspecto central de nosso plano disposto no lower park, e os outros detalhes e arranjos estão mais ou menos desenhados em conexão com ele ${ }^{44}$.

43 OLMSTED apud McLAUGHLIN, op cit, p 124.

44 OLMSTED, idem. 
Os playgrounds são concebidos como espaços livres nos quais, vez por outra, apresentam-se algumas construções de apoio que podem receber o uso de jogos, ou exercícios. São compostos de clareiras gramadas cujos contornos irregulares estabelecem congruência com o desenho dos caminhos e lagos.

O nordeste do plano prevê a implantação de um arboretum de árvores americanas. A idéia de coleção subsumida na idéia do arboretum não dá lugar a um disposição formal; ao contrário, está pensado como uma ambientação que retrata o orgulho da diversidade da flora do território americano, bastante pequena se comparada com os trópicos, mas em torno de cinco a seis vezes o número das árvores autóctones inglesas 45.

O plano apresenta ainda uma prática imortalizada por Repton em seus Livros Vermelhos, Red Books, são esboços que mostram a cena antes e depois da intervenção. Essa estratégia apresentava ao júri o cenário que Olmsted e Vaux pretendiam construir, ao mesmo tempo em que, segundo a argumentação, resguardavam o lugar que sobreviveria à ocupação e crescimento da cidade. Esse espaço livre testemunharia a riqueza de uma paisagem anterior em contraponto à monotonia das ruas retas, e possibilitaria o restabelecimento da saúde e vitalidade física e mental em face ao desgaste da vida citadina 46.

Propõe-se algo para além do modelo inglês pastoral; cria-se uma corrente de represamentos irregulares e caminhos sinuosos de rochas expostas: é uma brilhante, brava, anti-pastoral, solução americana a que Olmsted imaginou. As férias de verão para aqueles que podiam custear já significavam as paisagens selvagens de Adirondacks ou das White Mountains de New Hampshire. Mas para os "milhares trabalhadores exaustos" que não tinham meios, nem tempo para gozar de tais prazeres, algo da original selvatiqueza de Nova lorque deveria ser preservada 47.

45 OLMSTED apud McLAUGHLIN, op cit, p 133.

46 Downing já havia argumentado em meados do século sobre a necessidade de existência desses espaços na cidade: “...uma terapia contra o caos, a sujeira e a violência da metrópole moderna. Contudo, sua solução paisagística , posta em seu artigo, apresentava uma peculiar mistura entre entretenimentos modernos e sentimentalidades pastorais. Tanto quanto estufas que comporiam o parque, Downing previa mostras de artes industriais, um zoológico, bem como um virgiliano Panteon aos valores americanos. O parque ofereceria solidão aos Rousseaunianos de Manhattan que procurassem por solidão, e encontro aos gregários. SCHAMA, op cit, p 567.

47 SCHAMA, op cit, p 569. 
Os arquitetos projetam um lugar que supre demandas não apenas dos tempos presentes, mas principalmente, prevêem um parque para uma cidade de prováveis dois milhões de habitantes 48; apresentando, já no plano Greensward, o dado que afirma estar a população crescendo para além da meta prevista, desde $1800{ }^{49}$. Logo de início fica claro que o parque será um sucesso de público e que seu papel na cidade será reconhecido pelas muitas classes sociais que ele visitam.

A partir de 1858, a Comissão que gere o parque indica Andrew Green como seu presidente. Seu espírito controlador pouco confia em seus subordinados e o trabalho de Olmsted se vê ameaçado por um superior que o controlava nos menores detalhes ${ }^{50}$. Sua permanência frente à superintendência terá mais alguns anos de fôlego, propiciados por uma licença para visitar a Europa e estudar seus parques uma vez mais 51 , bem como pela própria guerra civil que fará com que Olmsted acumule dois cargos.

\section{a guerra civil e sua participação}

\section{A questão referencial desse período é o trabalho de Olmsted como secretário executivo junto à Comissão} Sanitária. A Sanitary Commission foi organizada com propósitos de aconselhamento e investigação e não

\footnotetext{
48 Em carta escrita em maio de 1872 ao editor William Robinson, da revista inglesa The Garden, Olmsted argumenta que o parque mesmo nesse ano ainda está distante do centro, contudo, prevê que em dez anos, o parque estará envolto por compacta cidade, por isso a grade de ruas já se apresenta projetada. OLMSTED apud OLMSTED Jr \& KIMBALL, op cit, p 96.

49"Até o presente momento, no planejamento dos trabalhos públicos da cidade de Nova York, em nenhuma instância têm sido tomadas providências para enfrentar o crescimento da população e negócios, (...). Uma sábia previsão para o futuro garantiria ao parque proposto o nome Central. (...) Há apenas vinte anos atrás a Union Square estava fora da cidade; daqui há vinte anos a cidade terá envolvido o Central Park". OLMSTED apud McLAUGHLIN, op cit, p 120.

50 Mesmo um corte de grama, ou o plantio de árvores deveria ter a autorização do presidente, a situação chega a um impasse quando Olmsted apresenta sua demissão em janeiro de 1861, mas a Comissão o faz rever a ação em seguida: "Mais que tudo, Olmsted finalmente percebia que não era apenas suas capacidades como artista e gerente de trabalhos que eram postas à prova, mas também sua reputação como homem honrado e honesto". ROPER, op cit, p 154.

51 Através do Office of Works of Her Majesty's Palaces and Parks, Olmsted faz uma visita privilegiada aos parques de Londres. Em Paris, tem oportunidade de encontrar-se com Adolphe Alphand, então diretor do Departamento de Estradas e Pontes. Alphand havia sido engenheiro chefe do prefeito Haussmann que pusera em marcha a reforma de Paris e o desenho das promenades. Era também autor de projetos de parques através dos quais exprimia um ideal de simplicidade e verdade como critérios de beleza, não apenas como opção estética, mas a partir de considerações econômicas. Segundo os Le Dantec, Alphand era um burguês na acepção do termo e qualquer despesa percebida como supérflua numa porção de natureza que recebesse trato de arte era moralmente repugnante a seus olhos. Cf. LE DANTEC, op cit, p 192.
} 
solicitara poderes legais para sua existência, apenas o reconhecimento oficial e moral de sua natureza civil e voluntária. A penúria dos homens que se alistavam para a guerra como voluntários, suas necessidades básicas como alimentação de qualidade, vestimenta e condições sanitárias, a higiene do acampamento militar, são as primeiras demandas apontadas pela Comissão, que nesse momento conta com a ajuda dos ingleses em sua experiência com a British Sanitary Comission.

O ponto a ser destacado é a arguta observação realizada por Olmsted e as soluções propostas, nem sempre aceitas pelos oficiais; havia sempre a suspeita de que a Comissão ganhasse poder e se tornasse algo mais que uma assistência estratégica para humanizar o campo de batalha. A Comissão Sanitária carregava até outubro de 1861, quando generais do Oeste fundam a Western Sanitary Commission, a bandeira de ser um símbolo de unidade e nacionalidade. 0 esforço para levantar fundos, a gestão destes e principalmente a transparência com que essas operações eram levadas a cabo acrescentam ao currículo de Olmsted a marca de gestor e articulador político de visão.

Durante o tempo em que Olmsted permaneceria em Washington secretariando a Comissão sua autoridade junto ao parque será esvaziada definitivamente ${ }^{52}$. Em meados de maio de 1863, Vaux entrega a carta na qual oficializa seu desligamento, junto com Olmsted, do cargo de Arquitetos da Paisagem do Central Park 53.

Contudo, a rotina da Comissão é tão desgastante quanto fora a do Parque, o desrespeito parecia ser o maior inimigo; quando recebe a oferta de emprego para gerir uma grande empresa na Califórnia, e pensa em aceitar, recebe carta de seu superior na Comissão Sanitária, Henry Whitney Belows, argumentando que não pode conceber um abandono como o que Olmsted planejava empreender; que sua figura é importante para o país, e suas responsabilidades para com ele urgiam e não poderiam ser postas como equivalentes a uma tentação pecuniária. Olmsted receberia por ano quase quatro vezes o que recebia como superintendente no parque, não há dúvida de que a questão monetária e familiar, agora que se casara com a viúva do irmão, fazia diferença;

52"Ele(Green) teve tanto sucesso minimizando o papel do superintendente que ninguém mais se incomodava em consultar Olmsted quando ele estava por lá, ou escrevia a ele, quando ele estava em Washington, a procura de aconselhamentos”. ROPER, op cit, p 179.

53 OLMSTED, Jr \& KIMBALL, op cit, pp 70 a 74. 
mas foram as sucessivas quebras de expectativas que parecem ter sido a principal causa dessa transposição para o outro extremo do território: Eu não penso que eu seja tão sábio quanto você alega, ao contrário, sou menos influente, meu conselho e informação são de menor efeito do que eu sinto que eles merecessem, muito menor. Há algo errado nisso... e eu espero que indo para a Califórnia me torne merecedor de obter mais respeito de meu julgamento ${ }^{54}$.

\section{a experiência em Mariposa Estate}

A idéia de coordenar a prospecção de ouro de uma imensa área de 70 milhas quadradas, cuja população flutuante é de aproximadamente 7.000 homens, entre americanos, índios e estrangeiros, especialmente chineses e mexicanos, era no mínimo perturbadora. Os banqueiros que adquiriram a propriedade diziam conhecer a reputação de Olmsted e acreditavam em sua capacidade de realizar a tarefa 55 .

Pouco tempo depois de sua chegada, após investigar os livros e administração anterior ele encontra lucros forjados e custos omitidos; sua gestão estava posta em questão antes mesmo que assumisse suas responsabilidades. Olmsted procura contornar a situação tirando da experiência desse Oeste ressequido a possibilidade de, uma vez mais, humanizar a bárbara situação reinante.

Após ter tido sua primeira impressão do lugar, ele se propõe a refletir acerca de suas características e encetar uma estratégia com a qual alcançasse seu propósito maior: o homem civilizado. Sua sensibilidade sempre atenta às qualidades dos homens percebia que o que Ihe faltava em refinamento, sobrava em versatilidade, o homem da fronteira tinha essa como sua principal qualidade. Olmsted acreditava no poder do progresso social, no potencial humano que ali jazia sob uma história de abandono e omissão.

54 OLMSTED em carta a Below de agosto de 1863. In Belows's Papers apud ROPER, op cit, p 235.

55 OLMSTED em cartas ao pai, (agosto de 1863 e fevereiro de 1864), afirmaria não ser comerciante ou guarda-livros; aos 42 anos, Olmsted está temeroso sobre o futuro,e procura compreender como a operação funciona: "Os mineiros escavam espalhados pela propriedade, (...) as pipetas de ouro são pulverizadas, amalgamadas e convertidas a lingotes, recebem um selo de identificação e vão pelo Expresso Wells Fargo da propriedade para os banqueiros em São Francisco. "Apud ROPER, op cit, pp 233 e 235. 
A primeira providência seria trazer água para o lugar, levar o ramo sul do Rio Mercedes através de um canal que atravessaria toda a propriedade; a água não só prolongaria as atividades de mineração que eram paralisadas na época das secas, mas transformaria toda ela num jardim, o cultivo e o pastoreio criariam condições de vida permanente, um novo lugar se desenharia 56.

Mas ele não poderia empreender nada disso sem água, e ela é recusada pela empresa, as minas têm um desempenho bastante flutuante, no mais das vezes deficitário. A experiência terminará do pior modo, com a venda da propriedade para outros donos que não assumirão compromisso com Olmsted. 0 traço mais marcante desse período, para além da confirmação de uma ordem de razões que the guia o pensamento, fortemente alicerçada no vínculo entre o desenvolvimento humano e o desenvolvimento do lugar, e na expressão dessa união pela paisagem, é seu encontro com uma outra Natureza.

A propriedade da Companhia, Mariposa, ficava a Oeste de Sierra Nevada, de onde se tornavam visíveis os contornos de Yosemite Valley. Esse vale havia sido reconhecido como propriedade inalienável pelo presidente Lincoln em julho de 1864, pouco antes de Olmsted e família empreenderem sua viagem de férias para o lugar. Seus registros mostram um maravilhamento sem precedentes: Não é numa cena, ou em cenas que seu charme consiste, mas em milhas de cenário nos quais penhascos de tremendas alturas e rochas de vastas magnitudes e variadas e belíssimas cores estão à margem e se apresentam orladas, drapeadas e sombreadas pela delicada folhagem das nobres e amadas árvores e arbustos, refletidas pelas mais plácidos espelhos de água, e associados aos mais tranqüilos meandros, a maior parte deles com corredeiras brincalhonas e toda variedade de suave e pacífica beleza pastoral. A união da mais profunda sublimidade à mais profunda beleza da natureza. 57

\footnotetext{
56“Olmsted concebe nada menos que uma radical tarefa de engenharia social: transfigurar o semi-árido, bárbaro lugar em bem irrigado, belo jardim; transformar sua economia, de perigosa dependência em industrioso e diversificado negócio; e modelar sua transitória e semi-bárbara população numa estável e civilizada comunidade na qual deverá prevalecer uma relação baseada na confiança, respeito e interesse de cada cidadão com o todo..." ROPER, op cit, p 257.

57 OLMSTED, Frederick Law. The Yosemite Valley and Mariposa Big Trees. A preliminary Report, 1865. In Landscape Architecture no. 43, Outubro de 1952, p 16. Introdução do artigo por Laura Roper.
} 
O Olmsted cidadão parecia haver predominado nos anos da guerra civil e na chegada a Mariposa; as responsabilidades nublavam o sentimento poético, que vez por outra se deixava entrever em suas observações e correspondência; porém, o Olmsted artista sempre estivera lá.

Prova disso são suas anotações sobre o significado da Landscape Architecture postas em seus cadernos durante o período passado em Mariposa: "Arquitetura da Paisagem é a aplicação ou a relação pinturesca de vários objetos circunscritos em um certo espaço, de modo que cada um possa ampliar o efeito no todo de uma composição da paisagem. Isso então abrange mais do que a jardinagem paisagística, incluindo arte e arquitetura os estende a ambas, levando-as para os domínios da pintura da paisagem. Na arquitetura da paisagem, não deve apenas existir a arte, mas a arte deve ser evidente. A arte de ocultar a arte é aplicável à manipulação dos materiais, o método pelo qual o grande resultado é obtido, mas não o resultado que deveria ser mera ficção natural, mas obviamente um trabalho de arte - cultivada beleza." 58

Ou ainda, a correspondência com Calvert Vaux, que se intensifica quando a Comissão reinicia conversações com os arquitetos para que retomem o trabalho junto ao parque. Os anos de ausência ocasionada pelas demissões de Vaux e Olmsted causaram danos à concepção original e um sentimento de perda por parte da sociedade se tornava expressivo, os jornais denunciavam e a população pressionava os homens que decidiam sobre os destinos do parque 59

Nesse período em que Olmsted ainda está na Califórnia surge a oportunidade de desenhar um grande parque nas vizinhanças da cidade de Brooklyn. Vaux escreve à Olmsted clamando por seu auxílio no que chama: a tradução da republicana idéia de arte em sua mais alta forma para os acres do projeto ${ }^{60}$.

A esse apelo junta-se um último por parte de Calvert Vaux a Olmsted: Você é, como eu sou, e muitas outras pessoas são necessárias a esse trabalho, que pode ser conduzido com sucesso em seu espírito artístico a um

58 FISHER, op cit, Cf nota 14, p 29.

59 Uma carta ao New York Evening Post de junho de 1875, assinada por George E. Waring, originalmente engenheiro responsável pelos trabalhos de drenagem do parque e que por causa da guerra fica quinze anos sem o ver, é um misto de celebração de sua beleza e lamento de sua ingerência. OLMSTED, Jr \& KIMBALL, op cit, pp 104 e 105.

60 VAUX, apud OLMSTED, Jr \& KIMBALL, op cit, p 79. 
final real, (...), em ambas as dimensões, como um trabalho construído e como um organismo vital; mas depende de você - e o espírito com o qual você agora se aproxima dele - (...) Não retarde sua volta se possível. Afetuosamente, Calvert Vaux.

O cenário está pronto para a volta.

\section{o retorno ao parque e os anos de produção da Olmsted, Vaux \& Company}

Os anos entre 1865 e 1874 estão entre os mais ativos e complexos da carreira de Olmsted. A volta ao parque acontece em dois momentos; um primeiro, quando Vaux realiza um acordo com a Comissão, revela-se como inapropriado: renovados descasos às sugestões e aconselhamentos dos arquitetos da paisagem são coetâneos de uma gestão corrupta de governo; o que termina por resultar em novo desligamento em 1870. Numa segunda volta em finais de 1871, Calvert Vaux será consultor e Olmsted arquiteto da paisagem. Em 1872, Olmsted prepara uma balanço financeiro da situação do parque e discute especialmente o uso do Central Park pelo público; em 1873, apresentará um completo resumo histórico e estatístico do trabalho ${ }^{61}$. Em outubro de 1872 , por razões de conveniência mútua, a sociedade entre Vaux e Olmsted terminará, embora eles ainda trabalhem juntos em alguns projetos posteriormente.

Vinte anos depois de um ano decisivo como 1846, o ano de 1866 também se mostrava ímpar. Um retorno que não se configurara como meio de conduzir o parque de modo mais autônomo leva Olmsted a desenvolver outras frentes de trabalho. A carreira de escritor parece oferecer uma oportunidade quando Olmsted, cedendo ao amigo e jornalista Godkin, passa a operar como editor auxiliar no periódico Nation. No início desse ano, Olmsted, que retornara em novembro de 1865, prepara junto a Vaux uma análise apresentada à Comissão de Parques do

61 OLMSTED, Jr \& KIMBALL, op cit, pp 92 a 95. Também em SUTTON, op cit, pp 9 e 10: “Ele demitiu-se do projeto cinco vezes, sempre retornando, atento a cada detalhe, protegendo-o contra as frivolidades da política". Quase vinte anos foram necessários para completar o Central Park, e as tensões e confrontos com os chamados por Olmsted homens 'práticos'. levaram-no à beira do colapso nervoso em mais de uma ocasião 
Brooklyn; produzindo não só uma análise do espaço livre em questão, mas especialmente os propósitos do futuro Prospect Park 62, que receberá boa parte da energia da Olmsted, Vaux \& Company então.

O Olmsted cidadão continua a se envolver em associações que julga fundamentais como a Southern Famine Relief Comission, comissão baseada em Nova lorque que buscava organizar fundos e modos de lidar com a penúria e fome posteriores à guerra civil nos estado sulinos. Vincula-se, outrossim, à American Social Science Association, por acreditar nas benesses da pesquisa e reunião de informações para reformar e melhorar a sociedade 63.

Nos inícios de 1870, Olmsted escreve: Public Parks and the Enlargement of Towns, afirmando serem os parques não apenas um bom investimento para a cidade, mas uma dívida da municipalidade para com seus cidadãos ${ }^{64}$. Aqui se apresenta a idéia de que a questão do plano deve ser pensada a partir da estrutura que articula espaços livres: o que inclui parques, grandes e pequenos e o sistema de ruas e avenidas, parkways, cujo desenho de qualidade engendra o controle sobre o território da cidade.

O período que separa a preparação do primeiro balanço à Comissão de Parques do Brooklyn desse escrito de 1870 será aquele em que Olmsted amadurecerá sua reflexão; chamado para analisar e projetar lugares, nem sempre terá suas idéias aceitas, ou de fato implantadas, contudo, aquilo que sua percepção colhia será posto sob a forma de textos, que constituem documentos preciosos para a compreensão do papel dominante da paisagem na sua concepção de plano.

62 The Papers of Frederick Law Olmsted, volume IV, The Years of Olmsted, Vaux \& Company; 1865-1874. SCHUYLER, David and CENSER, Jane, editors. The Johns Hopkins University Press : Baltimore and London, 1992, p 20.

63 SCHUYLER \& CENSER, op cit, pp 7 e 9.

64 ROPER, op cit, p 317. A respeito da publicação de Frederick Law Olmsted, Public Parks and the enlargement of Towns, (Cambridge : Riverside Press, 1870); ver nota 6 do capítulo XXVII : New Parks, new Suburbs, 1868-1872. 
Antes mesmo de retornar da Califórnia, Olmsted passa seu tempo final na Costa Oeste palmilhando São Francisco para depois, já em Nova York, através de mapas e levantamento fotográfico propor um plano contratado para um comitê de superintendentes. A proposta, que incluía um parque para a cidade, assegurava de modo visionário um lugar para as gerações futuras da cidade que seria a porta americana para o Pacífico 65 . O plano é descartado, mas sua estratégia de concepção, que trama dados físicos e humanos, experiências diretas e mediadas, como a cartografia e os sensos, projeções e cenários futuros, ensaia o que virá a ser a grande estratégia do que atualmente se elabora enquanto leitura das cidades.

$\mathrm{Na}$ reflexão que acompanhava a proposta realizada para uma propriedade que pretendia estabelecer um College em Berkeley, na Califórnia, Olmsted não realiza apenas um plano do campus, mas empreende uma vizinhança, uma comunidade para um local desocupado 66. O Morrill Act, fruto de diretrizes federais desse período posterior à guerra civil, prevê a possibilidade dos estados venderem terras federais e criarem oportunidades educacionais. Olmsted participa desse debate examinando a relação entre a educação superior, as demandas da vida adulta e as necessidades da comunidade. Olmsted acreditava ser "a função primeira de um campus intensificar a qualidade da vida rural. Para que um College treine com sucesso o homem civilizado, o campus deveria assemelhar-se a um 'modelo de vizinhança rural' ou comunidade” 67.

Olmsted planejava segundo sua argumentação 68 um lugar não apenas em cumplicidade com seu ambiente natural, mas que também fosse capaz de expressar as qualidades formativas pretendidas. Ao mesmo tempo previa que se a empreitada tivesse sucesso e recebesse novo fôlego, demandando ampliações, que a própria

65 “O relatório demostrava uma tal minúcia e uma tal previsão, dando espaço para a expansão da cidade e das necessidades dos cidadãos, que permite ser Olmsted considerado como um pioneiro planejador de cidades; o relatório aplica pela primeira vez seus princípios de arquitetura da paisagem a um parque rural em um clima não adequado ao estilo paisagístico inglês". ROPER, op cit, p 303.

66 ROPER, op cit, p 305. Também conforme nota 14: OImsted Vaux, \& Company, Report upon a Projected Improvment of the Estate of the College of California at Berkley, near Ockland. San Franciso : Towne and Bacon, 1866.

67 OLMSTED, A Few Things to Thought of Before Proceeding to Plan Buildings for National Agricultural Colleges, december 1866. Apud SCHUYLER \& CENSER, op cit, $\mathrm{p} 13$

68 Também essa empreitada irá à falência pelo pouco capital arregimentado e a Universidade da Califórnia encampará Berkeley. 
estrutura indiciasse sua continuidade: ele concebeu o College como uma entidade orgânica, cujos edifícios deveriam ser arranjados de modo a propiciar o crescimento sem destruir a beleza da totalidade 69.

O princípio orgânico transparece em sua determinação de alcançar um desenho que expresse a congruência entre os usos destinados à instituição que lá se pretende construir e a forma física que esta toma, bem como entre a qualidade da arquitetura e sua implantação, entre o artifício do engenho humano e o lugar 70.

A experiência de setembro de 1866 junto ao Massachusetts Agricultural College segue o mesmo caminho dos planos frustrados elaborados para Berkeley. 0 que se recorta é a capacidade de Olmsted de pensar filosoficamente acerca da relação entre indivíduo e lugar. Contratado para refletir sobre uma implantação, retrocede ao processo de formação desse indivíduo que se liga ao College. A partir das informações que constrói, recusa a proposta inicial de arquitetura, defendendo sua impertinência: um único edifício implantado no meio de uma fazenda. Sua alternativa, pequenos edifícios relacionados na escala de uma pequena vila, é recusada por uma Comissão que insiste que a questão independe da tipologia do edifício já aprovado.

O balanço dessa situação é levada ao público em artigo no Nation de 25 de outubro de 1866 sob o título How not Estabilish an Agricultural College: Como não estabelecer uma faculdade de agricultura, fato que leva novo projeto para as mãos de Olmsted, o Maine Agricultural College, fadado a ser mais uma reflexão que não se constrói de fato .

Embora não haja frutos concretos, o cuidado com que cada um dos planos é elaborado para uma específica proposição, a ênfase em excluir o arbitrário, o ambíguo, o supérfluo, em especial a concentração em uma questão geral que subordina todo o resto e desenha os detalhes; bem como o grande mote da construção de uma cuidadosa congruência entre arquitetura e entorno, entre artifício, arte e natureza leva a uma atuação e postura que se tornam paradigmas da atividade profissional e posteriormente do campo disciplinar.

\footnotetext{
69 SCHUYLER \& CENSER, op cit, p 11.

70 "Tão imperativo era para Olmsted o princípio orgânico, que o levou a considerar a adequação do projeto artístico em relação à região e à localidade. O resultado em um projeto deveria ser localmente congruente e apropriado às condições originais do local”. FISHER, op cit, p 31 .
} 
Para Frederick Law Olmsted, a relação entre homem e natureza, entre o que se produz culturalmente, e a percepção ou elaboração de uma paisagem, fruição do fato natural, é vital para a sanidade humana 71 ; a Landscape Architecture, Arquitetura da Paisagem, sobre a qual escrevia estabelecendo seus fundamentos e potenciais definições, o mais poderoso meio para empreender essa experiência 72 .

\section{sistema de parques I - Brooklyn}

Em 1861, o mesmo engenheiro que havia realizado o primeiro levantamento do Central Park, Egbert Viele, havia determinado a terra e preparado um desenho para um parque na área do Brooklyn. A guerra civil suspende os planos e em 1865 o presidente da Comissão do parque, insatisfeito com os originais de Viele consulta Calvert Vaux sobre o assunto. Após examinar o lugar, Vaux propõe mudanças nos limites e disposições do parque pretendido e em junho, quando contratado, passa a escrever pedindo o retorno de Olmsted da Califórnia. Recém chegado em novembro, Olmsted elabora suas reflexões preliminares ${ }^{73}$ e as entrega sob a forma de documento em janeiro de 1866 .

Nesse documento, ele associa a importância dos parques como símbolo de uma nova vida comunitária, uma paisagem importante no processo de recuperação do incessante ritmo da vida urbana. Sua preocupação de que os parques fossem organicamente conexos à cidade, na medida em que o tempo passa, torna-se mais complexa em relação ao desenho do sistema de ruas, bem como na especificação dos transportes públicos que acessam espaço livre.

\footnotetext{
71"Implícita em cada reflexão estava a crença de Olmsted de que o homem era uma criatura maleável, que pela alteração favorável de seu meioambiente, poder-se-ia mudá-lo favoravelmente. Implícito também estava sua visualização da profissão e da arte da arquitetura da paisagem, uma visão fundamental e ruskiniana: (...) manipular o entorno humano para promover o melhoramento humano, física e espiritualmente. ROPER, op cit, pp 315 e 316.

72"Por causa da natureza dos materiais com os quais trabalhava, Olmsted seria capaz de incorporar a concepção orgânica, organic conception, de maneira mais direta e de modo correlato/relacionado aos filósofos e estetas românticos." FISHER, op cit, p30.

73 Brooklyn Park Comission, annual Reports 1861-1873, p 83 a 116. In SCHUYLER \& CENSER, op cit, p 20. 
A existência das parkways, que promoveriam o agradável deslocamento sombreado, são fruto desse processo que não pensa mais um parque, mas um sistema deles. O parque proposto para o Brooklyn tem seu significado pleno gerado pelo vínculo que assume com a estrutura viária urbana, reorganizando-a através da criação desse sistema de parkways. Elas determinam a reestruturação do sistema de tráfego e são os eixos do futuro desenvolvimento urbano ${ }^{74}$.

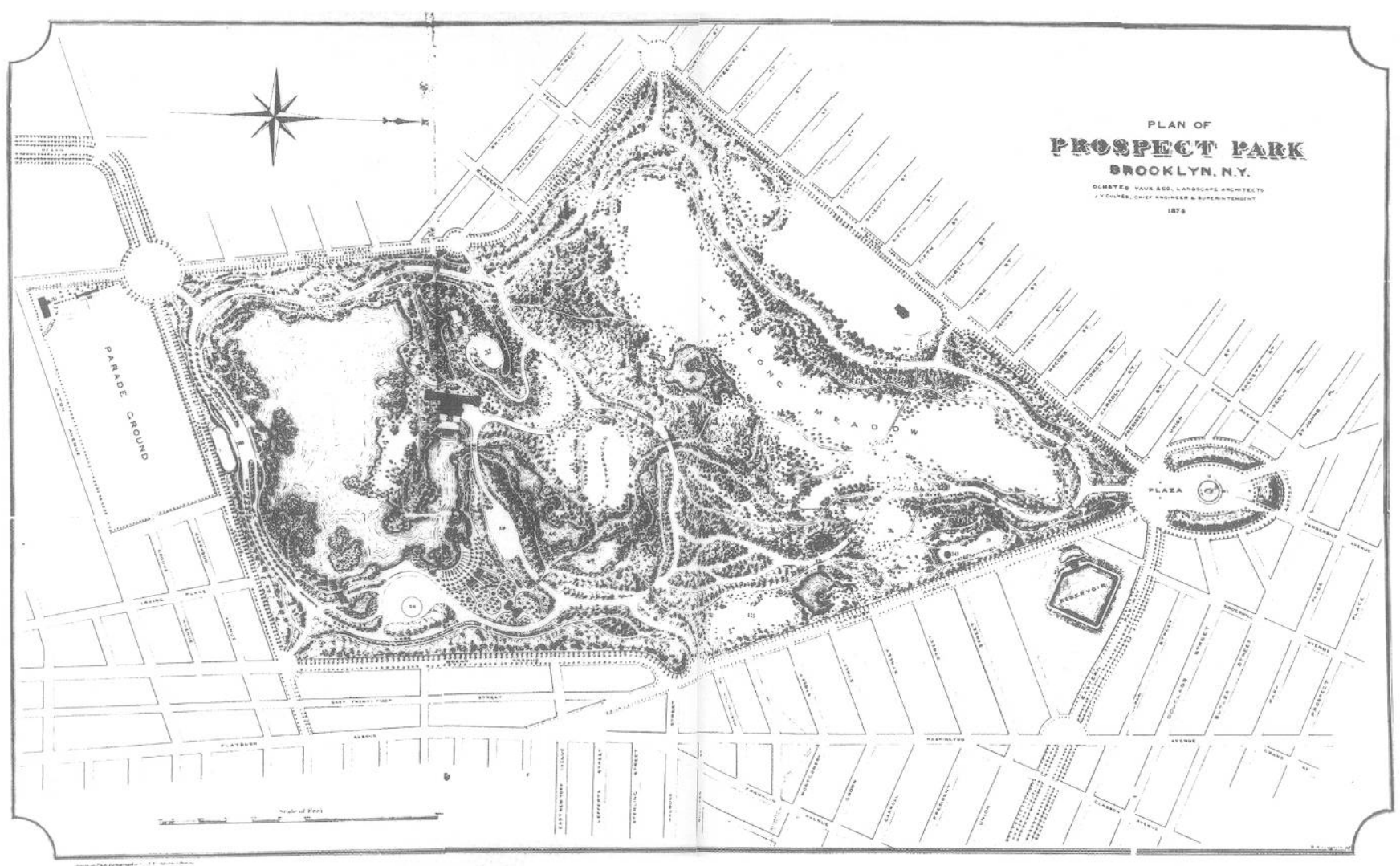

fig. 15 - Prospect Park

74 "Na descrição das soluções do Central Park é evidente a constante preocupação na relação com a cidade; isso se manifesta não apenas na implantação das vias de deslocamento, mas também na intenção de encontrar momentos e fórmulas de mediação entre a área do parque e a cidade circundante. (...) No Propect Park, Olmsted acentua decididamente o caráter de intervenção urbanística global que devia ter a ordenação do parque". DAL CO, op cit, pp 168 a 170. 
Não há dúvida de que a própria história desse parque, que imediatamente se torna o lugar favorito de descanso e lazer da população, é a chave para a compreensão do porquê foi possivel levar adiante essa estratégia ${ }^{75}$ : a Comissão do Prospect Park recebe a incumbência de administrar outros espaços públicos do Brooklyn, o que se transforma na oportunidade de trabalhar algumas das idéias esboçadas pelos arquitetos.

Os pequenos parques seriam articulados por parkways à peça chave, o Prospect Park, em um elaborado sistema de parques, que pretendia ter unidade em seu todo, embora guardasse particularidades em cada um de seus projetos. Os desenhos do Prospect, do Parade Ground, do Washington e do Carrol mostram a capacidade de seus idealizadores que buscaram um comprometimento na criação de parques que servissem a necessidade de vários grupos de pessoas ${ }^{76}$.

No início de 1878, trocam-se em Nova lorque
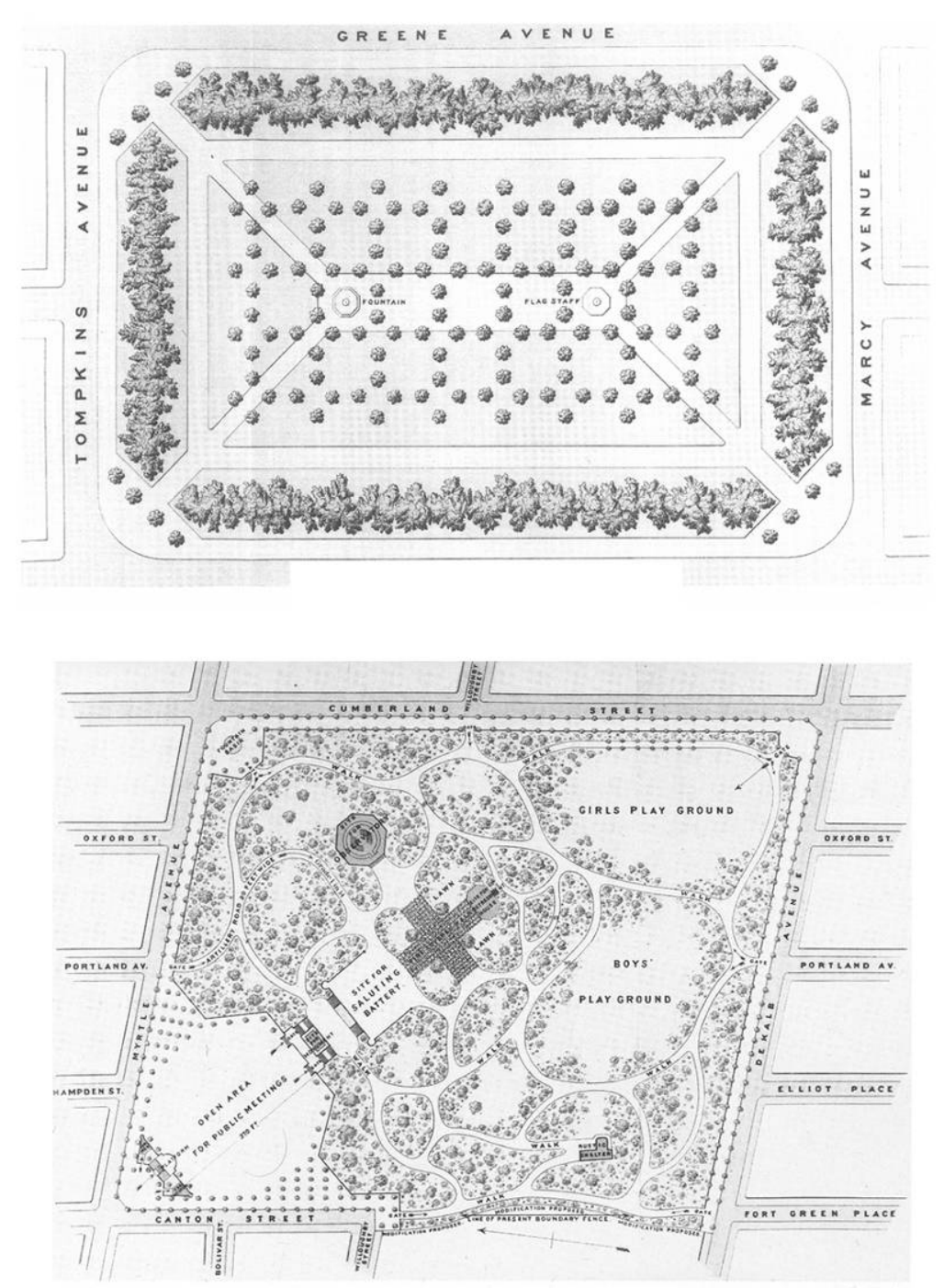

fig. 16 - Imagens de dois parques do sistema. Superior: Tompkins Park, 1870. Inferior: Washington Park, 1867.

75 Afirma Sutton, não ser tarefa fácil contornar a urgência dos políticos que fazem a gestão da cidade, e que no caso da Comissão do Brooklyn havia uma feliz exceção com a qual Olmsted e Vaux trabalharam harmoniosamente podendo prever e implementar, ao longo do tempo suas idéias. SUTTON, op cit, pp 11 e 12.

76 SCHUYLER \& CENSER, op cit, pp 24 e 25. 
os políticos e as cadeiras das Comissões; a do Central Park declara não haver mais necessidade dos trabalhos de Olmsted, apenas como consultor esporádico, Vaux é apontado com arquiteto da paisagem; na verdade extinguem não só o escritório de projetos, [Bureau of Design], e a superintendência, mas todos os escritórios sob sua tutela. A mudança de Olmsted e família da cidade de Nova lorque será um processo lento que se inicia no verão de 1878 e só se completa em 1881. Contudo, mesmo depois de deixar a cidade, Olmsted sempre arranjará um modo de passar pelo Prospect Park, declarando-o em carta ser ele uma das coisas que mais se orgulhava haver concebido ${ }^{77}$. Nesse projeto ele pretendia ter alcançado a almejada dimensão que acreditava ser parte da profissão: educar o público através do lugar; esse é o tema de outra carta, também de 1886, escrita para Charles Eliot, promissor arquiteto e filho do presidente de Harvard, e um dos principais articuladores do futuro sistema de parques de Boston.

\section{sistema de parques II - Boston}

Charles Eliot e o jornalista e editor Sylvester Baxter lideram a promoção da idéia de construir um sistema de parques para a cidade de Boston. Os trabalhos se iniciam efetivamente sob a autoridade da Cidade e a Comissão Metropolitana de Parques em 1893 procurando por terras apropriadas para associar preservação e recuperação a um possível uso ${ }^{78}$. 0 balanço realizado e publicado pela Comissão do Departamento de Parques da Cidade de Boston mostrava que a primeira necessidade da Back Bay Fens era a melhoria de pestilentas condições; o Fens era um pântano no qual juntavam-se as águas do rio Charles e do córrego Stony, que na época das chuvas ampliava seus incômodos 79 .

A paisagem original da cidade de Boston em finais do século XIX havia sido fortemente modificada pela mão do Homem. 0 desmonte de morros e o aterro de áreas pantanosas resultaram não apenas na mudança de uma

\footnotetext{
77 Carta de Olmsted a A.A. Smith de 18 de outubro de 1886, in ROPER, op cit, nota 103 da página 403.

78 ROPER, op cit, p 453.

79 BOARD of COMISSIONERS of the DEPARTMENT of PARKS - CITY of BOSTON. Seventh Annual Report, for the year 1881. Boston : Rockwell \& Churchill, 1882, p 27. Apud ROPER, op cit,p 385.
} 
imagem que possibilitava a ampliação do território urbanizado, mas principalmente numa determinante alteração do fluxo das marés, que anteriormente contribuíam para esgotar e levar para o mar a água servida de bairros da cidade.

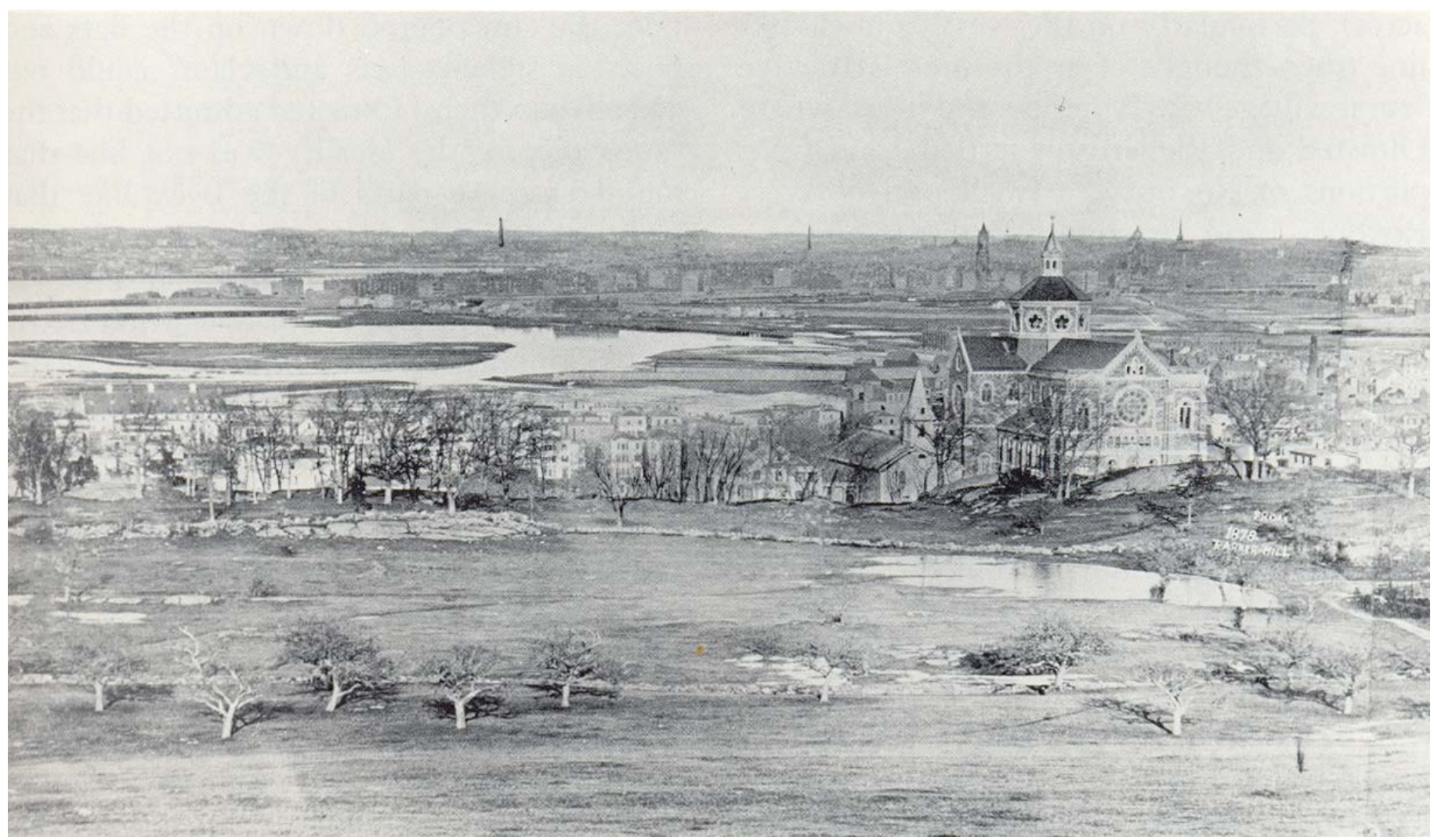

fig. 17 - Fens antes da implantação do parque, 1878

Apesar da técnica e a engenharia já serem capazes de lidar com as questões de drenagem, o Fens nunca seria um lugar inteiramente presente para o uso segundo reflexão do próprio Olmsted, o cenário arcádico nunca seria congruente ou apropriado. Suas condições geográficas e físicas faziam dele um natural descanso das águas, o mais sério desafio seriam os esforços para reverter as condições de proliferação de doenças relacionados ao 
cuidado com as águas servidas e a atenção aos fluxos das marés; o que fazia do investimento nas infraestruturas parte decisiva da empreitada. O grande ponto parecia ser a qualidade dessa infra-estrutura, que forma essa solução tomaria concretamente.

“Olmsted projetou o Fens como uma depressão de formato irregular, moldada a partir dos baixios da maré. A configuração e o tamanho da bacia de 12 ha permitiam que a quantidade de água dobrasse, com a elevação do nível da água de apenas poucos centímetros; durante as enchentes 8 ha adicionais poderiam ser cobertos pela água. Taludes com declives suaves e margens com contornos irregulares reduziam as ondas. Uma comporta na entrada do rio Charles controlava o fluxo das marés para prevenir as enchentes e melhorar o fluxo das águas na bacia. Parte do plano de Olmsted era a recuperação do antigo pântano de água salobra; ele dispõe às margens da bacia plantas que pudessem resistir à salinidade e tolerar as mudanças do nível das águas" 80.

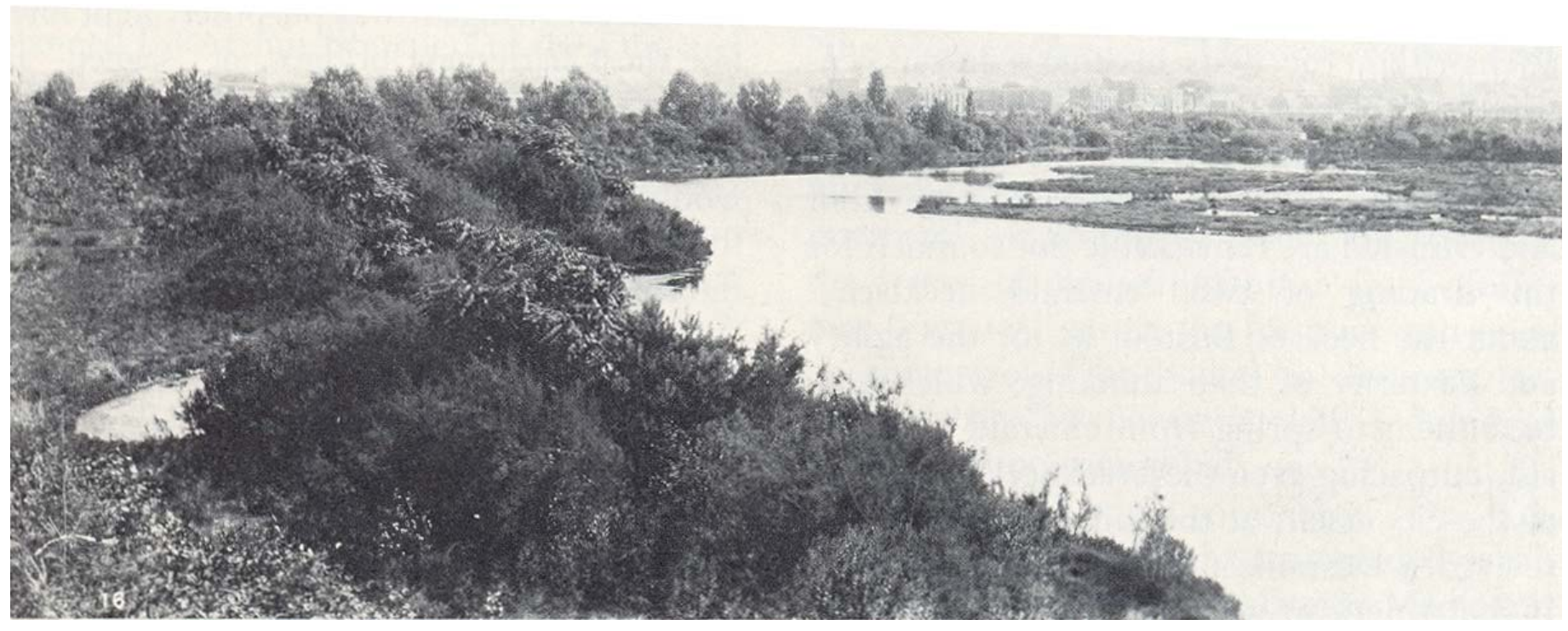

fig. 18 - Fens após implantação do parque, visão da Boylston Street Bridge

80 SPIRN, Anne W. O Jardim de Granito, a natureza no desenho da cidade. São Paulo : Edusp, pp 164 e 165. 
A solução que se apresentava não era apenas de qualidade técnica, sua resposta procurava trazer orgânica e congenitamente a alternativa da fruição, o deleite de uma paisagem produzida pela arte, um artifício aqui reitera características da paisagem: o Fens deveria aparecer como um gesto simples, embora um grande e sério esforço estivesse envolvido para produzi-lo 81; a perspectiva de uma distinta estética, uma delicada experiência operando como contraparte a uma realidade citadina feia e conturbada 82.

As duas lagoas presentes no Fens são versões que, distante algumas milhas, reproduzem a linha litorânea de Massachusetts, a intenção era emular as condições originais da paisagem, de modo que o mangue pudesse ganhar espaço e qualidade aos olhos do cidadão como elemento que participava de uma realidade originária 83.

Quando Olmsted defende seu plano frente ao Conselho da cidade na primavera de 1880, ele pretende deixar claro que as condições de subida e descida das marés e sua entrada no território, que as pessoas comumente denominavam com desprezo pântanos e mangues, têm uma característica e apelo muito diferentes em sua imaginação. Aos olhos daqueles que acreditavam no princípio orgânico sua lógica referendava os pulsos da Natureza e suscitava não só sua manutenção, mas um projeto que fosse capaz de provocar essa percepção, de sorte que a visão do mangue submetido à melhoria do artifício o transformava numa faixa de água esmeralda tão bela como o venerado mármore ${ }^{84}$.

Em seus planos, Olmsted engenhosamente soma à questão da solução dos desconfortos, a dimensão estética do princípio orgânico e todas as elaborações relacionadas ao sistema de parques que vinha desenvolvendo. A criação de uma passageway que ligaria a cidade aos seus subúrbios, passando pelo Fens, levaria a uma singular solução que buscava incorporar a área e fazê-la articular-se à cidade. Esses melhoramentos incluíam drenagem,

81 CREESE, Walter L. 'The Boston Fens', in The Crowning of the American Landscape. Eight Great Spaces and their Buildings. Princenton University Press : Princenton, New Jersey, 1985, p 172.

82 A convivência entre o mangue ou pântano e cidade seria nova em espaços urbanos objeto de projeto, essa situação, passível de crítica, recebe de Olmsted a seguinte argumentação: [ela] “...é um desenvolvimento direto das condições originais do local como adaptação às necessidades de uma densa comunidade urbana. Visto dessa maneira, será reconhecido como natural, no sentido artístico da palavra, e possivelmente sugerirá um modesto sentimento poético mais gratificante às mentes citadinas do que um elegante trabalho de ajardinamento poderia produzir". OLMSTED, apud ZAITZEVSKY, apud SPIRN, op cit, p 165.

${ }^{83}$ A fala de Charles Eliot em seu Report upon the Opportunities for Public Open Space in the Metropolitan District of Boston, de 1883 faz o elogio da paisagem original dos mangues e dos habitantes que não a desfiguraram. ELIOT apud CREESE, op cit, p 174.

84 CREESE, op cit, p 175. 
diques, calçamentos e pontes, num plano geral de desenvolvimento da região; as disposições procuravam gerar uma continuidade de espaços livres que ligavam o Common, o Public Garden, a Commonwealth Avenue, o Back Bay Fens, o próprio rio Muddy e seu vale superior, o Jamica Pond, o Arboretum até o parque rural de West Roxbury 85 .

Tratava-se de um conceito maior que qualquer um que tivesse trabalhado anteriormente. Embora certas questões participassem de trabalhos anteriores realizados com Vaux, nenhum deles tinha a escala da proposição idealizada para Boston ${ }^{86}$. 0 próprio Olmsted evitava o uso da palavra parque para o projeto como uma totalidade, e mesmo para o desenho do Fens; a palavra poderia suscitar expectativas que o lugar não lograria suprir; ele seria compreendido antes como um grande elemento articulador, um nó urbano 87 , presença que vinculava a estrutura urbanística circundante e determinava sua organização; um lugar que deixava de ser um vazio entrave para se tornar meio que asseguraria a continuidade entre partes da cidade, cúmplice de uma pretendida organicidade.

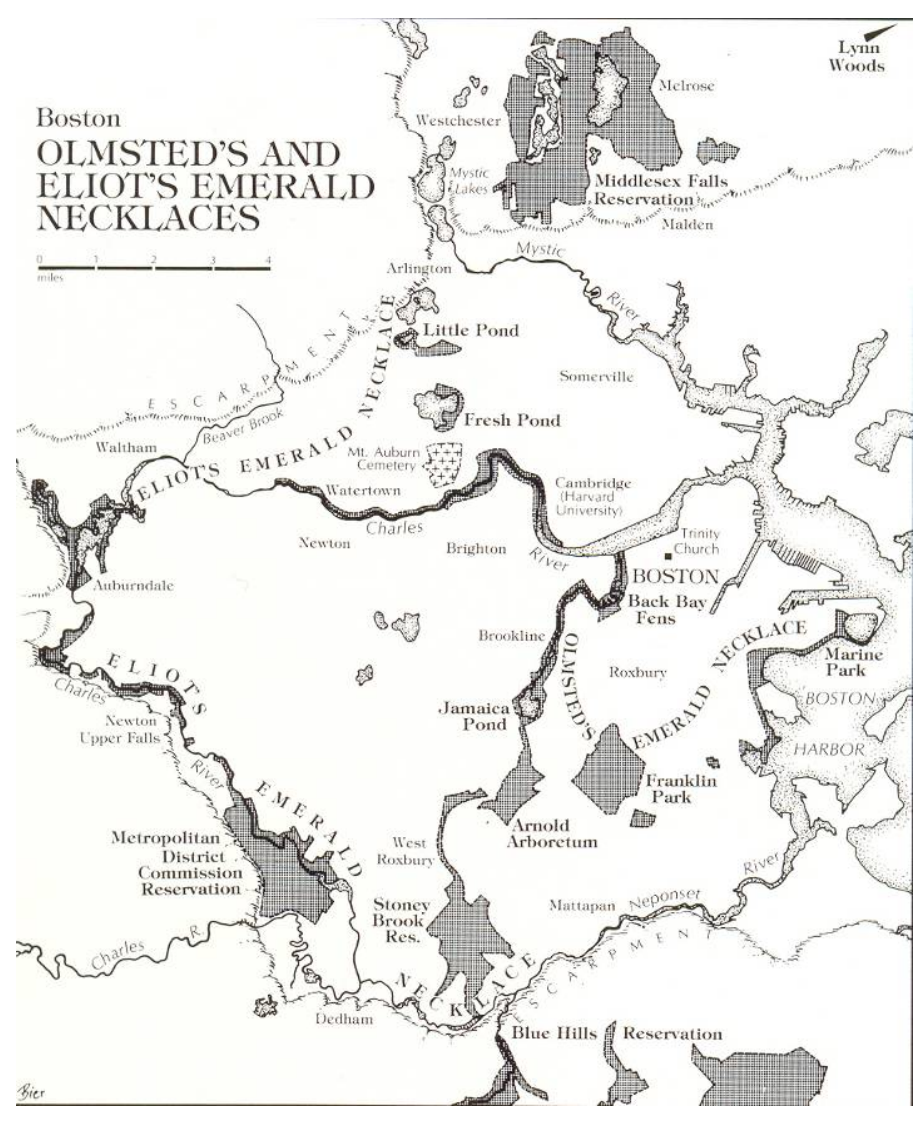

fig. 19 - Sistema de Parques da cidade de Boston

85 ROPER, op cit, p 385.

86 Robert Copeland e Horace Cleveland foram sócios em um escritório de Arquitetura da Paisagem e chegam a propor parques para a cidade de Boston em finais da década de 60. Suas contribuições são contemporâneas às de Olmsted para a área metropolitana de Nova lorque. Olmsted promovera a leitura de um documento, posteriormente publicado sob o título Public Parks and the Enlargment of Towns, para a American Social Science Association no Lowele Institut em Boston, em 25 de fevereiro de 1870, tendo provavelmente inspirado os arquitetos a uma primeira proposição. Olmsted estará em contato com eles a partir de então, especialmente Cleveland. Cf. ROPER, op cit,p 327.

87 DAL CO, op cit, p 171. O autor tributa aos escritos olmstedianos sobre a intervenção em Boston a mais sensivel das novas teorias sobre parques, nela a cidade em seu conjunto se converte no objeto de intervenção. 
É certo que o processo de construção de parques é moroso e dependente de legislaturas; é também muitas vezes, como no Central Park, objeto de ações políticas, ou simples mazelas hierárquicas. Nas chamadas vilas suburbanas, objeto da iniciativa privada relacionada ao capital, a questão do tempo é fundamental para a realização do lucro esperado e elas surgem em vários locais num fenômeno digno de nota. Segundo o próprio Olmsted, não se tratava de um processo que acontecesse apenas em território americano, ocorrendo também em cidades como Paris, Londres, Viena ou Berlin.

Nos Estados Unidos, em particular, havia então duas formas de subúrbios, os que reuniam comunidades cujos moradores haviam deixado a cidade para se estabelecerem na proximidade de seus negócios, como a que Olmsted participara quando de sua empreitada como fazendeiro em State Island, ou as que cresciam na periferia das cidades, ao longo das estradas em condições miseráveis e sem plano 88 .

A história de Riverside inaugura um modelo de comunidade que se estabelece num espaço livre e que como tal será inteiramente qualificado. Embora existissem experiências anteriores como as de Berkeley que o próprio Olmsted participara, havia uma novidade em curso nesse projeto contratado pela Riverside Improvement Company - o que se pretendia não era a proposição de uma peça isolada, mas uma paisagem que funcionasse como instrumento urbanístico completo, uma alternativa que estendia os benefícios da cidade e mitigava suas mazelas: a cidade em seu conjunto se converte em nova escala de intervenção urbanística 89.

\footnotetext{
88 ROPER, op cit, p 321.
}

89 DAL CO, op cit, p 170. O autor, a despeito da qualidade romântica que impregna o primeiro balanço realizado por Olmsted em seus Preliminary Reports, alerta para o perigo de uma interpretação anti-urbana da proposição; a matriz trancendental que participa de sua reflexão não descuida, ou renega a tecnologia: "nesse sentido o trancendentalismo crê na cidade, (...), não como instituição estática, mas sim como lugar dinâmico, modificável e reestruturável, de integração e composição de contradições”, p 148. 
A cidade de Chicago passa por terriveis acontecimentos em 1871. Um incêndio transforma em escombros a Garden City, cidade jardim, como era então conhecida dada a quantidade de espaços livres verdejados com que contava. Esse violento desaparecimento poderia explicar a iniciativa de estabelecer um lugar como Riverside 90.

A inspiração inicial remete a Birkenhead Park, mas inova na direção de uma solução mais global e especialmente ambientada para essa paisagem; Olmsted visita pela primeira vez o local em agosto de 1868; atento, escreve a Vaux 91 sobre a intensa especulação pela qual passa Chicago, mas estabelece um tom otimista: após percorrer um entorno desprovido de graça, encontra nas terras onde será estabelecida Riverside um lugar promissor e diferenciado. Até os finais desse ano, a partir dos levantamentos e das reflexões realizadas por Olmsted, são lançadas as diretrizes gerais do

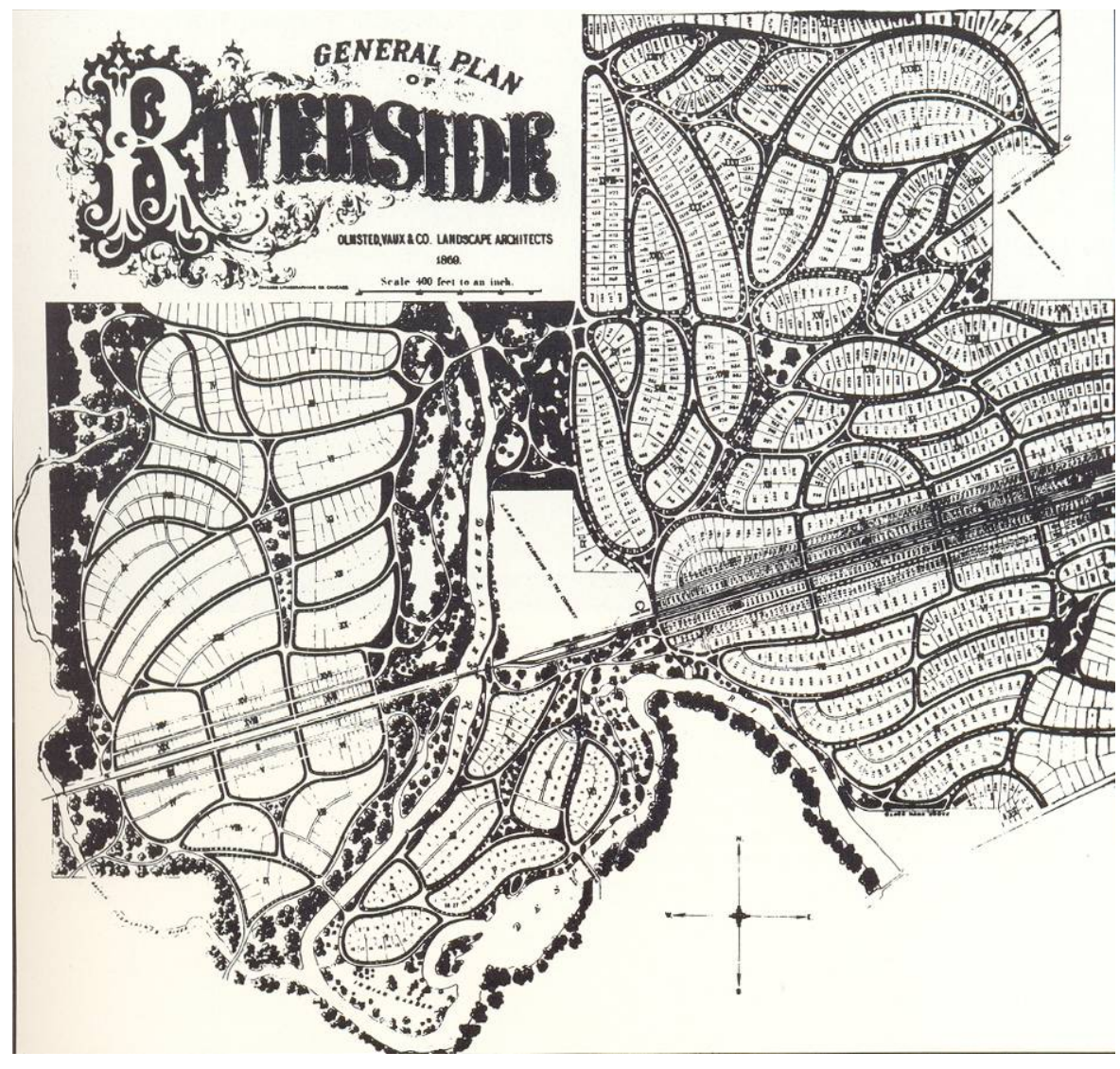

fig. 20 - Riverside, 1869.

\footnotetext{
90 "Por que esperar pelo lento desenvolvimento do tempo? (...) Um subúrbio com parques, calçadas, avenidas, um clube, tudo exclusivo, isso era o que os especuladores visionários diziam ser a grande solução para Chicago. Então o famoso jardineiro [sic] da paisagem do Leste [OImsted] foi contratado e a fazenda de Dave Gage se tornou o subúrbio da moda em Riverside". COOK, Frederick, Bygone Days in Chicago: Recollections of the Garden City of Sixties. Chicago : A.C.McMlurg \& Co, 1910, p 302, apud, CREESE,op cit, p 223.

${ }_{91}$ Carta de Olmsted para Calvert Vaux de 29/8/1868. In ROPER, op cit, p 323.
} 
projeto e se iniciam as obras.

Para tornar factível a idéia de nova urbanidade, a extensão dos domínios do urbano sob novas qualidades 92 um ponto fundamental seria a construção de caminhos e estradas de qualidade ligando o subúrbio à cidade. A totalidade dos caminhos foi construída com excelente trabalho técnico de drenagem e construção, bem como materiais e tecnologia.

A implantação pretendia promover dois aspectos da vida suburbana: a privacidade da vida em familiar e o convite da vida em comunidade; seus passeios arborizados, uma oportunidade de exercício e contato com uma realidade cujo ritmo era o contraponto da cidade.

Contudo, o contraponto mais marcante vinha do próprio desenho. Concebido em congruência com sua paisagem ${ }^{93}$ a implantação de Riverside serpenteia; desestimulando a rápida passagem, ela oferece diferentes enquadramentos a cada mudança de direção, essa estratégia buscava uma alternativa ao relevo pouco acidentado do lugar, que não suscitava o pinturesco como comumente concebido, mas guardava uma de suas principais proposições relacionada à variação.

Em abril de 1870, Frederick Withers, arquiteto supervisor ligado à Olmsted e Vaux reporta que as condições de execução da obra estavam insustentáveis ${ }^{94}$; havia uma denúncia contra o empreendimento de desvio e uso de dinheiro público, o tesoureiro da cidade era o antigo proprietário da fazenda onde se constrói Riverside, o rombo nos cofres públicos de meio milhão equivaleria ao que já foi gasto em infra-estrutura no local.

Parte do dinheiro que os empreendedores deviam aos arquitetos seria retirado em forma de lotes que a princípio pouco valiam, o empreendimento não teve sucesso imediato, contudo, o futuro próximo mostrou que a

92 Vincent Scully afirmaria ser essa tendência de "equalizar dispersão física e liberdade política" uma atitude que revelava a pouca fé na civilização urbana, engendrada desde Jefferson e fortemente arraigada na cultura americana. Esse ideário mostra-se falacioso com o passar do tempo, sendo objeto de críticas dos urbanistas. SCULLY, Vincent. American Architecture and Urbanism. New York: Holt, Rinehart and Winston, 1969, p 89

93"Os caminhos deveriam ser dispostos nas curvas de nivel para tirar vantagens das características naturais da terra, e as casas deveriam ser construídas a uma distância especificada mínima e acessadas por caminhos privados". ROPER, op cit, p 323

94 ROPER, op cit, p 324. 
qualidade do desenho e execução foram suficientemente bem constituídos para transformarem Riverside em lugar e empreendimento referenciais.

As instalações de Riverside não tinham precedentes e isso explica a quantidade de capital envolvido na operação. Os caminhos foram construídos num misto de asfalto e pedra, as ruas aplainadas com maquinário importado da Europa; foram gastos aproximadamente 9,5 km de encanamentos, $9 \mathrm{~km}$ de canos para gás, 200 luminárias urbanas ou postes, $26 \mathrm{~km}$ de drenos e milhares de árvores e arbustos numa profusão verde contínua uma vez que a disposições gerais orientavam os moradores a não construírem cercas ou muros 95 .

A diferença entre a cidade e esse novo subúrbio, explicava Olmsted para os empreendedores, estava além das facilidades, a tecnologia era meio sem dúvida utilizado, mas não fim: Nós não poderemos argumentar que o quê você oferece a respeito de gás, água, drenagem, acesso da rua e outros aspectos ligados à conveniência serão melhores do que os encontrados em algumas das mais desejáveis residências da cidade, mas o que, além do puro ar e das condições saudáveis, você pode oferecer, é o mais alto grau de gratificação propiciado pelo verdadeiro gosto 96 .

\section{a contribuição na distinção de uma atividade profissional}

Em carta a Harry Codman de 30 de julho de 1892, Olmsted afirma não existir nada na América que se compare ao cenário pastoral, de beleza pinturesca comum e própria à Inglaterra: Eu não posso sair sem me sentir deleitado, (...). Às vezes a questão se apresenta, se mesmo nas declividades atlânticas, não estamos tão longe das condições climáticas daquelas cujas belezas pastorais dependem, que é fútil lutar com nossas dificuldades.

95 CREESE, op cit, pp 224 e 226.

96 OLMSTED, Selection from the Papers of Frederick Law Olmsted, apud CREESE op cit, p 224. 
Mas quando penso quais são as alternativas, sempre concluo que nós devemos ser apenas mais criativos em nossos expedientes para ampliar nossas oportunidades ${ }^{97}$.

Olmsted defendia que as propriedades vitais dos elementos que participavam do projeto eram captadas e postas em jogo graças à arte do gênio; mas acreditava que essa atividade de criação não tinha como força primeira a expressão individual do artista; ao contrário, ele defendia o trabalho artístico que tinha como horizonte o compromisso com o coletivo dos homens: 0 verdadeiro trabalho do artista é menos expressar a si mesmo que produzir, para os outros, experiências estéticas de natureza elevada 98, que são aquelas das quais participa o impulso, a verdadeira força, e que produz uma sociedade melhor. É sob essa perspectiva que argumentava ser uma das obrigações fundamentais da Arquitetura da Paisagem educar o público a perceber e valorizar a Natureza da qual participava 99; produzir trabalhos que suscitassem a visão na população em geral: esse ser capaz de ver, em Olmsted, relaciona-se ao gosto, que o arquiteto da paisagem acredita ser objeto de construção e estímulo. A ordem de razões une a dimensão do sensível na produção de experiências estéticas como estratégia fundamental para engendrar o cidadão de gosto elaborado, a existência desses lugares poderia potencialmente torná-los capazes de apreciar o que Ihes ofereciam em conjunto as artes e a técnica.

O cotidiano, porém, traduziu-se sempre em árduo embate. A crítica Mariana Griswold Van Rensselaer, contemporânea de Olmsted, afirmava não haver mais que seis Arquitetos da Paisagem nos Estados Unidos àquele tempo; o campo de trabalho, por outro lado, era largamente ocupado por viveiristas, engenheiros e jardineiros, mostrando que se era necessário educar público e governantes, era ainda mais urgente esclarecer a qualidade e investir na distinção desse profissional. A única formação possível então era unir-se a um desses seis profissionais como aprendiz, ou derivar num processo tão randômico quanto havia sido o do próprio Olmsted ${ }^{100}$. Qualquer uma das alternativas era pouco satisfatória para algo que clamava tão singulares

97 ROPER, op cit, pp 441 e 442.

98OLMSTED apud ROPER, op cit, p 435

${ }^{99} \mathrm{Em}$ carta a Charles Eliot de 28 de outubro de 1886. ROPER, op cit, nota 107, p 403.

100 Os livros de Olmsted estavam por toda sua casa e testemunhavam a miríade de interesses que Ihe detinham a atenção: novelas, clássicas e contemporâneas; poesia, biografias, memórias, livros sobre formas de governo e políticas, diplomacia, história, sociologia, filosofia e religião; educação, viagens, viagens oceânicas e explorações; ciência e medicina; traduções dos gregos e latinos; balanços governamentais e 
competências e relevâncias; uma atividade que pretendia ultrapassar o mero comércio de mudas, ou mesmo o conhecimento como o do jardineiro, ou do engenheiro para ser a expressão de uma singular convergência entre técnica e arte ${ }^{101}$.

Anterior ao estabelecimento do primeiro programa de graduação em Landscape Architecture, Arquitetura da Paisagem, sob a direção de Frederick Olmsted Junior, em Harvard, 1900-1901, data a fundação da ASLA, American Society of Landscape Architects, de 1899. Essa organização, embora recebesse em seu título a denominação arquitetos, não se restringiu a eles, ampliando seu quadro a amadores da paisagem, jardineiros, superintendentes de parques, engenheiros, escritores e artistas em geral - sua participação só era vetada àqueles que guardassem alguma ligação com atividades comerciais. A revista Landscape Architecture inicia-se em 1910 e se torna o veículo que procura tornar conhecida a profissão ao mesmo tempo em que esclarece quais são os objetos e objetivos dessa prática ${ }^{102}$. Esses acontecimentos testemunham a questão cultural que envolve o nascimento do campo disciplinar e o desenvolvimento da atividade profissional em território americano.

Olmsted falece em 28 de agosto de 1903, após quase oito anos de senilidade, momentos de lucidez e confinamento; retira-se em 1895, os últimos dez anos à frente do escritório demonstram o largo espectro de projetos com os quais a atividade poderia estar em contato: para além do jardim ou parque, na estreita congruência entre as idéias de lugar e natureza dos projetos, planejamento e cidade 103: Olmsted fez muito mais

institucionais; fábulas, Bíblias e livros de culinária, dicionários e enciclopédias; textos sobre matemática, engenharia, botânica e geologia; livros sobre arte, arquitetura, mágica e xadrez. "Alguns velhos amigos como Milton, Bunyan, Zimmerman, Gilpin, Emerson, Ruskin e Mill, Olmsted mantinha no criado-mudo ao lado da cama." ROPER, op cit, p 345.

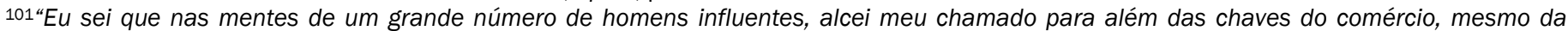
artesania, para aquele de uma profissão liberal, uma arte, uma arte do design...”. OLMSTED, apud OLMSTED, Jr \& KIMBALL, Forty Years of Landscape Architecture, volume I, pp 68 e 69, apud SUTTON, op cit, p 13.

102 SIMO, Melanie. 100 Years of Landscape Architecture. ASLA Press: Washington DC, 1999.

103 Entre os projetos destacam-se, a Universidade de Palo Alto na Califórnia e a propriedade de George Varderbild, Biltmore State, na Carolina do Norte, 1888, cuja pretensão seria a de ser a primeira propriedade a combinar funções de reserva à um empreendimento economicamente rentável; bem como os planos para a Exposição Mundial em Chicago, 1893, elogiados por críticos e sociedade. 
que o projeto de um parque, mais que uma batalha com os políticos, (...): introduziu uma idéia - a idéia de utilizar a paisagem de forma criadora - Tornando a natureza urbana, ele naturalizou a cidade ${ }^{104}$.

A divisão de funções que tomará forma no urbanismo Moderno distinguindo suas partes, como o morar, trabalhar, recrear-se ou circular, já participa das investigações olmstedianas sobre as comunidades suburbanas como a projetada para Berkeley e a construída em Riverside. Porém não operam como parte de uma argumentação que as isola, uma vez que sua reflexão transita sob a égide do princípio orgânico que a tudo procura unir, defende a coexistência mediada das partes; o subúrbio proposto não é mono-funcional, mas um microcosmo planejado em congruência com a paisagem. As vantagens desses assentamentos derivam principalmente destas serem uma alternativa realista à congestão, conciliando o contato com a natureza com as vantagens da comunidade urbana 105.

Todas essas informações pretendem trazer um personagem que representa um momento de viragem, um pivô no que diz respeito à arte e paisagem, à cidade e seu projeto. A princípio sua filiação ao pinturesco, a imagem de seus projetos e seu discurso muita vez romantizado, em especial quando defende a criação como fato inteiramente subjetivo, poderiam fazer pensar que se trata de um indivíduo ligado à tradição, anti-moderno por excelência. No entanto, Olmsted guarda dimensões profundamente modernas em sua fala e atuação. A primeira delas diz respeito à vinculação entre a qualidade da intervenção e sua vital contribuição na sociedade da qual participa; o projeto é meio, instrumento contra a barbárie 106; a construção do homem civil é projeto moderno.

Outra preocupação sempre presente e fortemente desenvolvida nos projetos finais de Olmsted relaciona-se aos avanços técnicos, à obra projetada e à cidade como uma só questão. Fruto de reflexões tornadas visíveis pelo contexto moderno, como o crescimento das cidades e a industrialização, são ensaiadas respostas para esse fenômeno que implicam em qualidades de articulação, deslocamentos e acessos entre partes da cidade; bem como em espaços livres de qualidade, ruas e avenidas arborizadas, parques e praças, a idéia de um sistema

104 MUMFORD, Lewis. The Brown Decades, A Study of the Arts in America, 1865 - 1895. Dover Publications Inc.: New York, 1971, p 40. Apud DAL CO, op cit, p 166.

105 DAL CO, op cit, p 170.

106 ROPER, op cit, pp 315 a 317 e 328. 
que funcione como contraponto e complemento 107. Essas experiências, por sua vez, atualizam em seus expedientes questões estéticas elaboradas no século XVIII, como continuidade ou diferença, e as traduzem, o que significa dizer que a passagem dos modos de uma forma pinturesca é parte fundamental na criação do que será o motor de uma nova estética: a questão da percepção.

A preocupação com as lógicas próprias ao meio-ambiente urbano suscita a reflexão acerca da congruência entre projeto e lugar, sua natureza física e humana; associada a esta, o artifício que resulta numa paisagem. Essas relações realizam outra passagem singular aos trânsitos modernos: a especificidade de cada relação que se percebe constrói em conjunto o projeto, que deixou de possuir um guia, uma norma estabelecida a priori. A intensa liberdade experimentada é devedora apenas da qualidade de associações que se elabora, revelada ou expressa pelo projeto construído 108. Porém, torna-se sua refém se o processo criativo estiver subsumido à pequena razão já mencionada em capítulo anterior. Foi contra essa razão, que dominou os homens práticos, que Olmsted travou inúmeras batalhas.

A pretensa confusão entre natureza e paisagem revelou origens remotas e conduziu a uma série de desdobramentos especialmente relacionados à questão das intervenções: buscava-se investigar o que estaria por trás, enquanto fundamento, dos projetos dessa paisagem. O inaugurar de um campo disciplinar ligado à figura de Frederick Law Olmsted faz entrever a arte que o informa, fundamentada no século XVIII e de matriz filosófica romântica. A presença das questões sociais participantes desde a origem estabelece especial relação com essa forma estética, pautada no princípio orgânico e que compreende a Natureza e seu projeto como o momento privilegiado de encontro entre arte e técnica na constituição de uma Paisagem.

107 “O trancendentalismo implica numa reflexão sobre a utilização da máquina, (...) Nesse sentido o trancendentalismo crê na cidade, (...) não como instituição estática, mas sim como lugar dinâmico, modificável e reestruturável; lugar pois, de integração e composição de contradições”. DAL CO, op cit, p 148.

108É inspirado por essa liberdade, que só se realiza plenamente sob o compromisso da responsabilidade social e em consonância com a Natureza, que Olmsted recusa a solução simplificadora do tabuleiro ortogonal todas as vezes em que se pensa em planejar a cidade. Quando em 1874, terras para além da ilha de Manhattan são adquiridas para a ampliação futura da cidade de Nova lorque, Frederick Law Olmsted, em cargo de chefia à frente do New York Departaments Bureau of Design, e J.J.R.Croes refutam enfaticamente a solução proposta em grade, alegando ser um reducionismo cuja ordem de razões contrariava a experiência do lugar, especialmente em relação ao trecho de relevo mais acidentado, pinturesco e naturalmente sinuoso entre a avenida Riverdale e o rio Hudson. A solução vencedora imprime a manutenção do modelo original sob estreita defesa de ser essa a imagem do perfeito planejamento. Cf. OLMSTED, Frederick Law \& CROES, J.J.R. Preliminary Reports, doc.72, p 4. Relativo às notas 50 a 54, in ROPER,op cit, p 355. 
A Modernidade pareceria conflitar com esse desenvolvimento de uma visível continuidade, ainda que traduzida, em relação aos séculos anteriores. A questão que se coloca finalmente ensaia acerca desses contatos; mudanças e permanências ocorridas como perspectiva de investigação para desenvolvimentos de projetos de espaços livres.

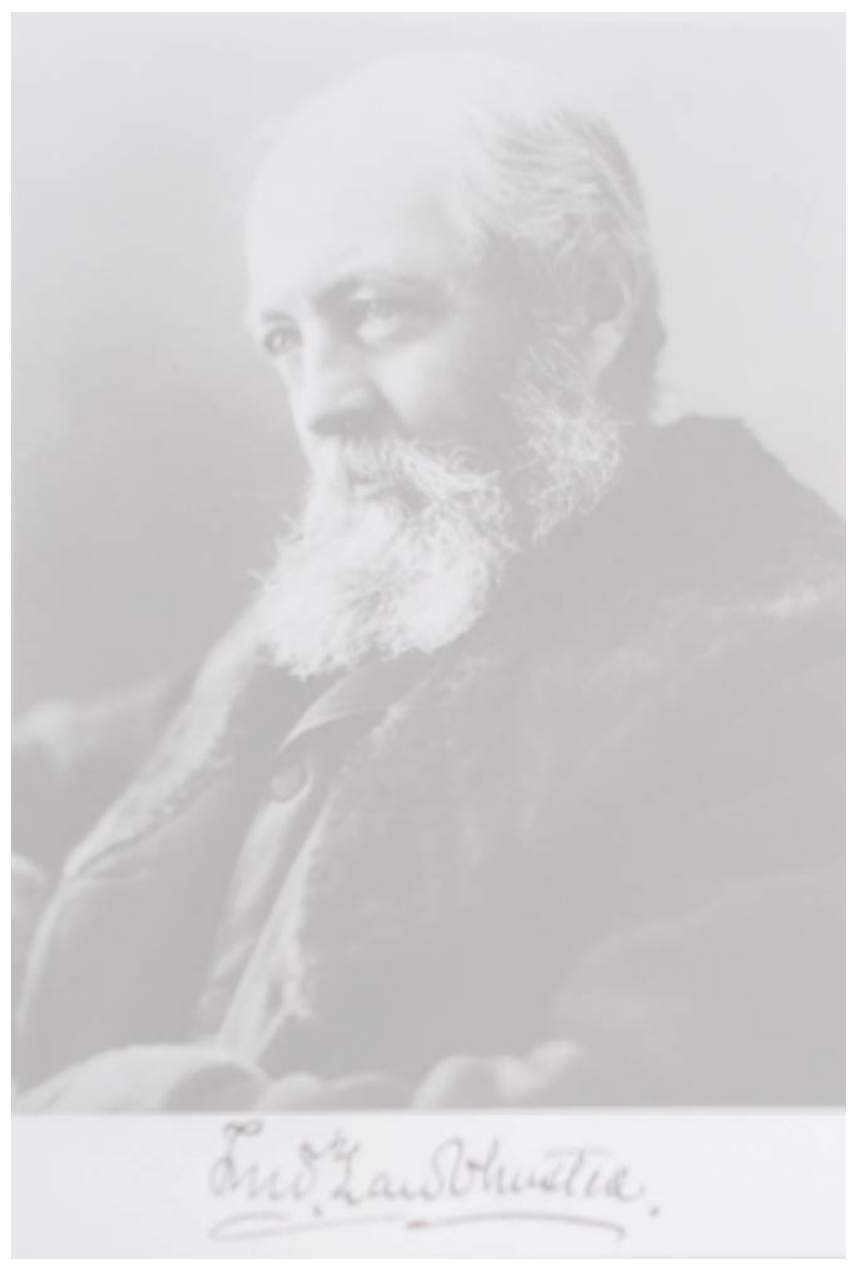

fig. 21 - Frederick Law Olmsted 


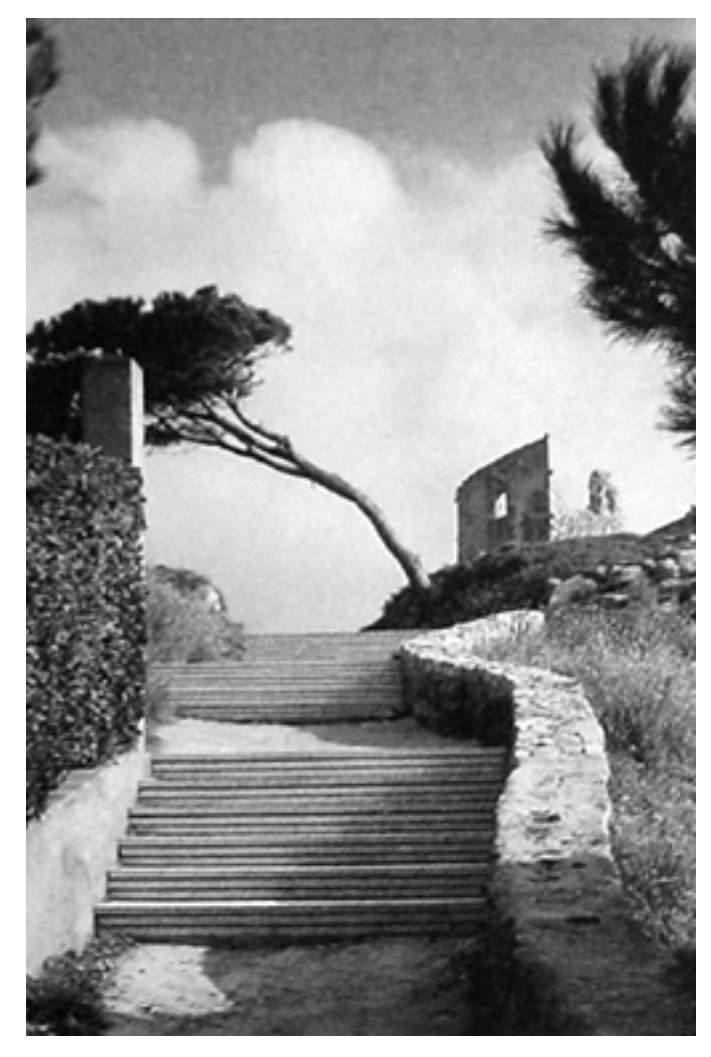

conclusões V 
Toda a Modernidade é atravessada por essa condição de Ulisses. Por isso o homem moderno não se perde no jardim, mas sim recorda a partir dele: jardim e parque, paisagem e natureza só adquirem sentido porque existe cidade junto aos simulacros de harmonia. o projeto de subsumir-se na natureza significa a intenção de esquecer a dor de nossa real condição ${ }^{1}$.

\section{É bastante complexa essa construção que coteja a Modernidade à existência de uma resposta ou expressão no} âmbito do jardim e da paisagem especialmente associada à sua dimensão cultural 2. A historiografia é unânime em datar a existência de um jardim moderno ligado aos movimentos de vanguarda a um período relativo às primeiras três décadas do século XX. Há, contudo, aqueles que vislumbram nas frestas, na obra daqueles que fugiam à chave dominante, não apenas uma resposta, mas os caminhos pelos quais o Moderno se desenvolve.

No que diz respeito às paisagens que se estabelecem em escalas de abrangência maiores que as do jardim, sempre dentro da perspectiva que as compreendem como construção cultural, são elas lugares privilegiados para a observação e reflexão dessa relação, muita vez conflituosa e descompassada. O intuito dessa conclusão é antes apresentar questões que versam sobre esse pretenso impasse, o Moderno e a Paisagem, e que guardam potenciais campos de investigação para futuros desenvolvimentos ligados ao projeto de espaços livres contemporâneos.

\footnotetext{
1 SILVESTRI y ALIATA, op cit, p 201.

2 Nos dois últimos capítulos de Viena Fin-de-Siécle, Schorske desvenda o jardim como um dos palcos onde se representa a emergência da modernidade ocidental entre finais do século XIX e inícios do XX. O jardim expressa as mutações de sensibilidade das elites sociais e artísticas naquele contexto e se dá a partir dos escritores e pintores e não dos jardineiros. SCHORSKE, Karl. Viena Fin-de-Siécle, política e cultura. São Paulo : Unicamp/Companhia das Letras, 1989, pp 273 a 317. Outra autora, Jane Brown, busca investigar o que chama "filho perdido do movimento moderno internacional na arte, arquitetura e desenho: o jardim moderno". Sua procura supõe o retorno aos oráculos dos pioneiros da Bauhaus, seguindo seu êxodo pelo continente europeu até o refúgio temporal que Ihes ofereceu a Grã-Bretanha durante a década de 30, e sua posterior estadia, mais permanente na América,[do Norte] para lá então afirmar o genuíno [sic] desenvolvimento do Moderno. BROWN, Jane. El Jardín Moderno. Introdução. Gustavo Gili : Barcelona, 2000. Ou ainda, a fala de Le Dantec que afirma estar o jardim moderno no início do século XX, entre repaginações do clássico e inspirações impressionistas. O formalismo geométrico reivindicará para si a designação de moderno, dividido que está em duas correntes na Exposição Mundial de Artes Decorativas de 1925: o Art-déco e os cubistas, associados à pintura de vanguarda e o Movimento Construtivista. LE DANTEC, Jean Pierre. 'O Eclipse Moderno do Jardim', in LEENHARDT, Jacques, org. Nos Jardins de Burle Marx. São Paulo : Perspectiva, 2000, pp 100 a 103.
} 
A presença dominante do jardim chamado paisagístico, que promove o modelo que se emula por todo o século XIX, é tida por autores como uma das causas do descompasso entre o projeto de espaços livres de então, e a Modernidade. Há uma mudez teórica no campo da Arquitetura da Paisagem no que diz respeito à investigação de lugares que o mundo moderno demandava ${ }^{3}$.

$\mathrm{Na}$ verdade, uma fundamental transformação havia sido iniciada na virada do século e expressaria uma das questões centrais da história do parque público e, de modo geral, também participaria da história dos jardins: Entre o final do século XVIII e os inícios do XIX a evolução do jardim sofreu, do mesmo modo que a arquitetura no período, de uma mudança de ênfase das estéticas para o funcionalismo. Uma modificação correspondente acorre na atitude daqueles para os quais os jardins eram projetados: no passado eles simplesmente fruíam deles como observadores, agora eles pretendiam fazer uso deles, organizá-los de modo que [esses lugares] preenchessem suas necessidades 4.

John Dixon Hunt corrobora dessa perspectiva que localiza por volta de 1800 um divisor de águas para a história da paisagem 5; ao mesmo tempo percebe nesse domínio que se desenvolve ao longo do século XIX, um novo padrão de percepção da natureza e produção de uma paisagem ligadas às questões do uso e função, relacionando-as geneticamente às causas da pretensa mudez: talvez o mais surpreendente aspecto da

\footnotetext{
3 “Dos finais do século XVIII, uma obsessão com um certo tipo de jardim - basicamente o paisagístico inglês, ou por vezes (significativamente) o jardim pinturesco (...) - parece haver prevenido a teoria de refletir acerca de muitos outros tipos de lugares que o mundo moderno demandava, (...). E a fixação em um tipo hipotético sem dúvida explica algumas das grandes oportunidades perdidas pelo século XX”. HUNT, op cit, p 289.

"O que distingue a arquitetura da paisagem do mero plantio é a arte. Um fator que obstrui o aparecimento de novas idéias é a persistência do naturalismo, ou tradição pinturesca." TRIEB, Marc. 'Axioms for a Modern Landscape Architecture', Introdução, in TRIEB, Marc, editor. Modern Landscape Architecture: a critical review. Cambridge, Massachussets: The MIT Press, 1993.

4 PONTE, Alessandra. "Public Parks in Great Britain and United States: From a 'Spirit of the Place' to a Spirit of Civilization'." In MOSSER and TEYSSOT, op cit, p 376.

5 HUNT, op cit, p 285.
} 
arquitetura da paisagem moderna tenha sido sua incapacidade de responder à essencial privatização da experiência da arte ${ }^{6}$.

Têm-se, portanto, hipóteses que começam a construir, há seu tempo, o que será qualificado como causa da invisibilidade da atividade de projeto da paisagem, significando sua pouca importância para o mundo moderno: em primeiro lugar a ausência de investigações teóricas consistentes sobre a questão de quais seriam as qualidades do espaço livre moderno, em especial tendo como horizonte a afirmação da ênfase funcionalista presente a partir de então. Ao mesmo tempo uma nova percepção de natureza implicaria numa outra produção de paisagens, o que leva a um conflito: uma das faces da modernidade é a qualidade de percepção que se desenvolve fortemente ancorada no indivíduo, a essa instância, os cenários romantizados de um pinturesco apaziguado pouco falarão, ou pior, serão a representação de um mundo passado e indesejável.

Existira um momento, especialmente ligado aos últimos projetos de Frederick Law Olmsted, no qual uma atividade profissional se esboçara com maior clareza em suas complexidades e ensaiara a clara pretensão de chamar a si o planejamento das cidades ${ }^{7}$. Esse processo amadurece ao longo do percurso desse pioneiro; mas esse movimento compartilha momentos e mesmo antecedentes na Inglaterra, onde a questão dos parques emerge a partir dos problemas gerados pelo crescimento das cidades e sua salubridade.

O artigo Breathing Places for the Metropolis, de John Claudius Loudon, publicado na The Gardner's Magazine em 1829, é escrito à luz de uma controvérsia ligada à ocupação de um espaço livre de domínio público no qual as pessoas costumavam passear. O escrito apresenta toda uma argumentação em favor da manutenção desse lugar, associando-o às necessidades da comunidade frente às lógicas que o crescimento sem planejamento da cidade vinha causando - a população de Londres havia duplicado nas últimas três décadas, sendo de um milhão e meio de habitantes em 1830. A par de protestar contra a ocupação, Loudon apresenta um plano para

\footnotetext{
6 HUNT, op cit, p 290.

7 "É suficiente lembrar que o conceito de parque é um dos principais meios pelos quais os reformistas do século XIX se esforçavam para melhorar a situação e, portanto a qualidade de vida". PONTE, apud MOSSER and TEYSSOT, op cit, p 373 . Nada mais natural que a arquitetura da paisagem, responsável pelo projeto desses parques fosse, agora que eles tomavam a forma de um sistema de espaços livres, responsável por essa tarefa de planejar a cidade.
} 
a cidade no qual mostra círculos concêntricos que alternam ocupação urbana com cinturões rurais, um esquema que relaciona questões econômicas, político-sociais, estéticas e sanitárias ${ }^{8}$.

Também um escrito de Edward Kemp, publicado em 1850, segundo Alessandra Ponte, seria uma informação especial nesse contexto. Kemp, colaborador de Joseph Paxton no projeto do parque de Birkenhead, afirma em seu tratado: How to Lay Out a Garden: A General Guide in Choosing, Forming or Improving an Estate, [Como projetar um jardim: um Guia Geral na Escolha, Formação e Melhoramento de uma Propriedade], afirmaria que: Um jardim é um conforto e uma conveniência, (...). É para expressar civilidade, e cuidado, e desenho, e refinamento 9 . As dimensões pedagógica e de civilidade são atreladas à questão funcional e relacionam-se à mudança do aporte estético para o funcional que veremos ser desenvolvida na produção de Olmsted 10, especialmente a partir de 1857, ano da competição de projetos para o Central Park.

O Movimento pelos Parques Urbanos Americanos, Park Movement, transforma-se substancialmente ao longo dos últimos cinqüenta anos do século XIX. O interesse romântico e literário pela Natureza se transformou em uma ideologia complexa, mas capaz de expressar-se com propostas de base científica, direcionadas a planejar totalmente o desenvolvimento urbano. No entanto, esse Movimento que pretendera pensar o plano da cidade a partir de seu sistema de espaços livres não logra controlar a cidade como um conjunto urbano e arquitetônico ${ }^{11}$.

A Modernidade constitui-se num mundo industrial, urbano e em movimento. O espaço público urbano, que havia sido o local essencial de inovação na Europa de meados do século XIX 12, nas proximidades do século XX,

\footnotetext{
8 As idéias de Loudon parecem antecipar questões que serão apresentadas por Ebenezer Howard, (1850-1928), que apresentará o conceito de cidade-jardim.

9 KEMP, apud CHADWICK, G.F. 'The Park and the Town', apud PONTE, apud MOSSER and TEYSSOT, op cit, p 385.

10 "O fato de que esse conceito [civilização] estaria implicado com aqueles que envolvem o tema dos parques públicos é claramente relacionado àquela mudança descrita anteriormente, de uma aproximação estética para uma prática, funcional na arte do jardim. O recurso à noção de civilização - que sugere o orgulho nas conquistas técnicas, políticas e morais da sociedade - parece haver pretendido reviver uma prática que havia perdido seu sentido no mundo das belas-artes, reduzida a arte 'aplicada'. Esse desenvolvimento culminou no trabalho realizado por Olmsted. que celebrou o conceito de civilização transformando-o num movimento estético distinto. PONTE, apud MOSSER and TEYSSOT, op cit, $\mathrm{p}$ 386.

11 “... o salto de escala e a conquista dessa dimensão espacial de conjunto serão realizados não por pioneiros, mas pelos arquitetos de outro movimento, o City Beautiful". DAL CO, op cit, p 181.

12 "Tendo sobretudo como figuras de proa Barrilet-Deschamps, em Paris; Linné, em Berlin; Paxton, na Inglaterra e Law Olmsted, em Nova lorque". LE DANTEC, apud LEENHARDT, op cit; o excerto refere-se à nota 2 da p 99.
} 
apresentava-se num impasse em relação às fórmulas do chamado estilo paisagístico: o alfandismo,[sic] de certa maneira um paradigma desse estilo, acha-se em vias de ossificação dogmática e acadêmica desde 1875. De fato, as únicas criações vizinhas no campo formal que escapam a essa degenerescência são as propostas norte-americanas de Frederick Law Olmsted e de Calvert Vaux, sustentadas que estão por duas diferenças importantíssimas: uma escala espacial urbana completamente diversa e a inserção numa sociedade mais aberta e democrática do que suas homólogas européias ${ }^{13}$.

No entanto, a despeito desses aspectos, a arquitetura da paisagem mesmo em terras americanas não foi capaz de manter sua participação de forma decisiva no desenrolar do século XX. O Urbanismo apresentar-se-ia como a novidade técnica de gestão do fenômeno urbano, surgida também em meados do século XIX, quantificaria os problemas e registraria necessidades, substituindo os termos parques e jardins pelos espaços verdes 14; um processo que causaria reações tanto de profissionais quanto do campo disciplinar relacionado à Paisagem enfaticamente a partir da segunda década do século XX.

segunda parte

Invisible Gardens de Peter Walker e Melanie Simo tem no seu título a ironia da questão que fundamenta o livro: por que uma disciplina tão repleta de idealismo e soluções, a um só tempo práticas e economicamente viáveis, pode ter tão pouca influência e efeito? 15

\footnotetext{
13 LE DANTEC, apud LEENHARDT, p 100. A revisão do modelo de Adolphe Alphand em relação aos espaços públicos na Europa continental acontecerá pelas mãos do mesmo Jean Claude Nicolas Forestier que seria supervisor da seção de jardins da Exposição de Artes Decorativas de 1925. Sua publicação, Grandes Villes et Systèmes de Parcs, 1906, renova a questão em terras européias e se afirma francamente tributário do trabalho de Olmsted. Cf LECLERG, Bénédicte, 'Avant-Propos' e CHOAY, Françoise, 'Préface' in Actes du Colloques International sur J.C.N.Forestier. Paris : Picard éditeur, 1994.

14 LE DANTEC, apud LEENHARDT, p 99.

15 WALKER, Peter \& SIMO, Melanie. Invisible Gardens, The search for Modernism in the American Landscape. Cambridge, Massachussets : MIT Press, 1994, p 312.
} 
Dos pioneiros nas intervenções sobre a paisagem americana, iniciando pelo próprio Olmsted, passando por como a disciplina nasce e vai se estruturando nas Universidades dos Estados Unidos, os escritos de Walker e Simo procuram tornar visíveis fatos, personagens, projetos e contextos, na expectativa de trazer à luz as causas dessa invisibilidade.

A perspectiva da qual nasce a profissão parcialmente explicitada no capítulo anterior se desvia da corrente que se afirmará como dominante na modernidade nascente; para esta, as especificidades do lugar pouco, ou nada contam. A relação entre natureza, arte e técnica terá outra qualidade: o repúdio à natureza de matriz pinturesca será uma das chaves que se manifestam e que se torna modelo posteriormente no cenário mundial; a ela se alinham, entre outros, Mondrian e Le Corbusier.

Mondrian afirmaria que o aspecto natural esconde a expressão das relações que são de fato verdadeiras 16; a natureza de Le Corbusier, com o passar do tempo, torna-se mais e mais asséptica; nos inícios da carreira, compartilhava com o irmão da arte dos jardins, procurando, como Eric Mendelsohn, (1887-1953), buscar um sentido moderno também para o uso da vegetação ${ }^{17}$.

Todo o questionamento do porquê a atividade do Arquiteto da Paisagem e sua produção se tornarem invisíveis tem parte da resposta ensaiada por Walker e Simo a partir dessa dupla percepção: há um descompasso entre o Moderno que Gropius traz para Harvard a partir de 1937 e a matriz do curso de Arquitetura da Paisagem, que nasce da Faculdade de Horticultura, e que sob a direção de Olmsted Junior carregará toda uma bagagem estética que remonta ao século XVIII. Os autores argumentam que o foco de atenção projetado por Gropius e outros arquitetos vindos da Europa está em outros pontos, e o que se poderia se chamar Paisagem não vai muito além do perfeito e neutro cenário para que a peça arquitetônica pudesse ser claramente observada. Essa redução acentuaria nos Estados Unidos a divisão entre os cursos de Architecture e Landscape Architecture.

16“Em minha opinião o aspecto natural vela a expressão das relações. Se quisermos expressar relações exatas plasticamente, teremos de mostrá-las com maior precisão do que têm na natureza". MONDRIAN, apud SEUPHOR, Michel. Mondrian. New York : Abrams, pp 303 a 307.

17 Mendelsohn será um dos expoentes modernos que revelará em sua obra especial atenção às informações que a natureza física do lugar apresentava; a natureza contribuía para a produção e o solo, em sua rugosidade e modelado seriam companhia do edifício, claro contraponto à corrente racional-funcionalista que será dominante na Modernidade. Cf BROWN, op cit, p 25. 
Garret Eckbo elabora num artigo na Pencil Points em 193718 acerca de sua insatisfação com os eixos e pontos focais - fórmulas para a concepção dos jardins e áreas livres objeto de estudo e modelo no curso de Arquitetura da Paisagem de Harvard. Também fora aluno de Gropius na Harvard de finas de 30, e embora crítico da perspectiva historicista do curso, não estaria de acordo com a redução a que a Paisagem parecia fadada dentro da perspectiva moderna dominante. Procurou em seus escritos ${ }^{19}$ por uma atualidade da atividade profissional, relacionando-a ao tempo presente de descobertas técnicas, à necessidade de novos aportes metodológicos e atualizações artísticas.

Em meados do século XX, os professores Hideo Sasaki e Stanley White procurariam atualizar os princípios de Frederick Law Olmsted fazendo constar propósitos sociais, artísticos e culturais nas ementas do curso de Landscape Design em Harvard. Stanley White era estudioso do trabalho de Charles Elliot, que produzira junto a Olmsted.

O artigo publicado por Sasaki na revista Landscape Architecture de Julho de 1950 defende algo que percebe ser fundamental participar dos currículos de então: a necessidade de atualizar o conhecimento da arquitetura da paisagem localizando-a como o projeto e planejamento do meio ambiente. Imprime nessa mudança de perspectiva uma especial atenção para a relação entre os objetos, e não o objeto de projeto isoladamente. A alteração da postura em relação ao processo faz dele o motor de uma nova didática. Algumas questões, por sua vez, referenciavam e estabeleciam uma continuidade com o trabalho de Frederick Law Olmsted. A situação de alteração das ementas segue um movimento que acompanha mudanças na sociedade americana20.

\footnotetext{
18 "Garret Eckbo, Dan Kiley e James Rose discutiram as novas possibilidades de ensino e outros planos para a comunidade, espaços urbanos e parques selvagens numa série de artigos na Architectural Record de 1939, e fazendo isso eles efetivamente almejavam reconquistar o território perdido da arte para a política..." HUNT, op cit, p 289.

19 ECKBO, Garret. Landscape for Living, Architectural Record : New York, 1950. Nesse livro, “Eckbo em primeiro lugar situa a arquitetura da paisagem dentro da principal corrente cultural e tecnológica do século XX. Ele argumenta pela adoção de um método científico como base de um conhecimento teórico necessário pela disciplina em sua missão de contra atacar os efeitos adversos do boom econômico pós II guerra. Eckbo caracteriza o método em termos de análise, hipótese e experimentação que constituem o aporte dedutivo da teoria. SWAFFIELD, Simon, ed. Theory in Landscape Architecture, a reader. Philadelphia : University of Pennsylvania Press, 2002.

20“Para os arquitetos da paisagem esses anos, (1945 - 1965), foram um período crítico de transição. A partir de um nível sem precedentes de desenvolvimento e expansão econômica, arquitetos da paisagem vislumbraram oportunidades que nunca tiveram - e talvez nunca mais as tivessem". SIMO, op cit,, p 129.
} 
Esse desenvolvimento apenas ilustra um fato: a tese da invisibilidade percebida pelos autores americanos, bem como a explicitação da estratégia que buscava resgatar uma origem e observar criticamente o desenvolvimento para compreender possíveis causas. Contudo, a incômoda questão permanece, e a hipótese de que parecia estar no moderno a origem da falta de importância imputada à arquitetura da paisagem não se sustentava inclusive frente aos exemplos que se apresentavam. Porque pelos exemplos é possível ver as frestas, pelas quais outros modernos e outras preocupações, que são também fruto desse Moderno, aparecem.

Na metade do século XX, período em que se reabilita a origem do campo disciplinar tendo como horizonte a atualização de seus conhecimentos, há uma grande oferta de trabalhos na América do Norte que coincide com o desenvolvimento do conceito de meio ambiente. Essa nova etapa sinaliza não só novas qualidades de informações, como o desenvolvimento do planejamento da paisagem, como demarcam uma insatisfação com o possível significado da atividade, de sorte que landscape designers passam a se denominar city and regional planner, planejadores da cidade e da região. Esse aposto em sua denominação, ou simplesmente a sua substituição, denotava a necessidade de tornar visível um aspecto de sua formação e profissão, bem como o escapar à equivocada compreensão que julga ser essa atividade apenas ligada ao jardim e à anacrônica idéia de Beleza desarticulada pela modernidade.

Embora a hipótese pareça frágil, a questão da invisibilidade parece repercutir também em território brasileiro: o aqui chamado Paisagismo é no mais das vezes reduzido àquilo que preenche os abstratos espaços verdes do plano, ou ainda, a atividade profissional que se solicita após haverem terminado as construções, aquilo que preenche o espaço vazio.

O primeiro grande personagem brasileiro a marcar a história da paisagem como uma inflexão diferenciada e importante é Roberto Burle Marx, e sua matriz é francamente Moderna 21. Pouco provável seria inferir a invisibilidade a partir do Moderno em nossas terras, talvez seja mesmo o contrário: o Moderno tornou visível nossa paisagem, fundamentalmente participou de sua construção, pelas mãos de Burle Marx a natureza nunca

${ }^{21}$ DOURADO, Guilherme Mazza. Modernidade Verde, Jardins de Burle Marx. Dissertação de Mestrado. EESC - USP, 2000. MOTTA, Flávio. Roberto Burle Marx e a Nova Visão da Paisagem. São Paulo : Nobel, 1986. 
se comportou como mero e neutro cenário. Há uma congruência entre arquitetura e paisagem no sentido de que, em sua percepção, o tratamento de ambas se define em concordância com o meio natural 22. É necessário, para esclarecer esse desenvolvimento, retomar uma vez mais a questão que coteja natureza e artifício para compreender aquilo que a primeira vista pareceria contraditório.

Em primeiro lugar é necessário ambientar a formação de Burle Marx e desvendar que sua ordem de razões e sensibilidade participam desse momento no qual a arte e técnica parecem constituir-se no poderoso meio que torna possível a redenção de um velho mundo. Essa articulação é o instrumento pelo qual o paisagista empreende sua missão social, que guarda pretensões pedagógicas e de emancipação. A paisagem e sua criação, por sua vez, inscrevem-se na esfera das necessidades: Não nos esqueçamos de que a paisagem também se define por uma exigência estética, que não é nem luxo, nem desperdício, mas uma necessidade absoluta para a vida humana sem a qual a própria civilização perderia sua razão de ser 23.

Michel Racine em seu ensaio, Burle-Marx - o elo que faltava, assinala um movimento que a historiografia já vem empreendendo nos últimos anos: constatar que o jardim fora, até a década de 30 do século XX, inseparável da arquitetura, e que imputar ao Movimento Moderno a invisibilidade do jardim e da paisagem é apenas uma reação desmedida 24 . Sua estratégia foi buscar nas resistências, no que chama fraturas, o fio que manteve viva a criação moderna, daí o encontro da obra não apenas de Burle Marx, mas, na própria Europa, a redescoberta daqueles que continuaram a exercer seu ofício de criadores de jardins 25 . Se for possível perceber um denominador comum entre eles seria sua formação clássico-humanística e seu desejo de buscar uma continuidade com a história e paisagem local. Para aí converge também Roberto Burle-Marx.

22 BURLE MARX, apud LEENHARDT, op cit, p 61.
23 BURLE MARX, apud LEENHARDT, op cit, p 47.

24 “Indissociável da arquitetura e da cidade até os anos 30, volta hoje o jardim como centro de todas as reflexões sobre o tratamento do espaço - ao mesmo tempo em que começamos a nos preocupar com os habitantes, com sua vida social, com o que se passa entre os prédios, com o conforto das ligações, com os meios de transporte, com o prazer dos sentidos na paisagem. No momento dessa redescoberta chegamos até a nos perguntar por que e como foi a arquitetura reduzida à produção de objetos autônomos jogados numa sopa ordinária chamada 'espaço verde'?(...) Ao buscarmos em que floresta de conceitos maléficos se produziu a ruptura, quem foi a bruxa, fomos excessivamente afoitos em acusar o 'movimento modernista' de ter oferecido a maçã do 'espírito novo', e assim mergulhado as reflexões sobre o jardim europeu num sono profundo. RACINE, Michel. 'Roberto Burle Marx, o elo que faltava'.In LEENHARDT, op cit, pp107 a 109.

${ }^{25}$ André Véra, Henri e Achille Duchêne, Jean Claude Nicolas Forestier, Ferdinand Bac, entre outros. A maior parte dos jardins é realizada no sul da França. Cf. RACINE, apud LEENHARDT, op cit, p 109. 
Há entretanto, uma questão de grande relevância dentro desse pioneirismo. Talvez porque o conhecimento técnico-científico que domina a obra de Burle Marx seja eminentemente de natureza botânica e não urbanística, sua experiência não cria escola nessa direção. 0 desenvolvimento de sua contribuição se apóia em qualidades de congruência ligadas às questões estética e meio-ambiental.

Muito embora uma das grandes qualidades de seus projetos seja o fato deles serem públicos, não passa pelo escopo de seu trabalho o pensar a cidade da mesma forma que pensara Olmsted. Isso possivelmente não tivesse a menor diferença no que diz respeito à participação do Paisagismo como elemento norteador de intervenções urbanísticas no Brasil; essa batalha já havia sido perdida em território americano onde o Urbanismo, quantitativo, prático e funcionalista, vence um oponente que havia construído, senão um corpo teórico consistente, uma prática e difusão de inigualável substância, mas cuja funcionalidade era baseada em questões de ordens humanística e natural, que se mostraram frágeis frente ao desenvolvimento moderno.

A questão, uma vez mais, é que não havia um corpo teórico sistematizado acerca dessa resistência ${ }^{26}$, e o que significava essa paisagem moderna que se construía, inclusive no que diz respeito ao que Ihe faltava. Existia uma produção que foi objeto de crítica muitos anos depois; contudo, a mudez sobre a qual se fala no início dessa conclusão, ou a invisibilidade de um campo disciplinar e atividade profissional reverbera por quase todo o século XX, apenas em suas últimas décadas é que se inicia com consistência esse debate.

Essa perspectiva que retoma a discussão pela fratura reabilita autores e práticas, e passa a refletir sobre as demandas do espaço atual. Autores que nos parecem referenciais nessa reconstrução são o inglês Christopher Tunnard, o americano Lawrence Halprin e o escocês lan McHarg.

Tunnard finaliza seu Gardens in the Modern Landscape 27 em 1938 e inspira toda uma geração de jovens arquitetos acerca da compreensão do jardim como obra de arte depois que vem para a América do Norte em 1939 e passa a lecionar em Harvard. A mudança que se consolida a partir de 1950 no curso de Arquitetura da

26 O livro do qual participam os ensaios de Le Dantec e Racine é editado por Leenhardt em 1994 com o objetivo de tornar visível ao público francês a obra de Burle Marx para além do lugar comum do exótico e instalar a discussão sobre o desdobramentos do jardim, e da paisagem modernos nos tempos atuais.

27 TUNNARD, Christopher. Gardens in the Modern Landscape. New York : Charles Scribner's Sons, 1948, 2a. edição revista e ampliada, (1938). 
Paisagem, e é impressa no livro de Eckbo, inicia-se na década anterior. Embora seja objeto de crítica por parte de autores como Dixon Hunt ${ }^{28}$, que o acusa de falta de rigor histórico; ou Jane Brown, que afirma serem os dois primeiros capítulos de Tunnard dedicados aos séculos XVIII e XIX pouco necessários ao propósito de escrever um livro sobre a paisagem moderna; seria possível criticar o livro de Tunnard também a partir da perspectiva de resistência, de fratura que sustém.

Simpático a muitas das idéias de seus contemporâneos colegas modernos, o que o diferenciava é que, através de seu interesse nas questões históricas que envolviam jardins e paisagens, preparava e apresentava seu ideário do que viria a ser o espaço livre moderno; de sorte que, a despeito de sua falta de rigor, há um claro endereçamento na sua fala. Os escritos de Tunnard enfatizavam flexibilidade, economia e ampliação dos usos humanos dos parques, jardins e corredores formados por canais e estradas de modo a constituir um sistema de espaços livres, numa clara sintonia com ideais modernos.

Ele acreditava ainda que o planejamento da paisagem se tornara elemento essencial nas soluções dos problemas modernos, seu projeto transcende o confinamento histórico ligado à horticultura e se move dentro dessa nova perspectiva artística, na direção da grande paisagem conformada pelo meio-ambiente ${ }^{29}$.

O Moderno apresentado por Tunnard incluía uma intensa relação com os principais expoentes desse período, a arte em seus escritos é afirmada como integração entre propósitos estéticos, funcionais e sociais, o lugar e suas informações. A arte se revelava, portanto, intrínseca ao próprio desenvolvimento, ela conduziria toda a produção em consonância com a técnica, é o meio que representa o fim do equívoco na percepção da Arquitetura da Paisagem como Belas Artes, que nada mais era que um estreitamento de suas proposições originais. Especialmente significava a afirmação, uma vez mais, da Arquitetura da Paisagem como campo de saberes vital para o desenvolvimento humano, reunindo uso e ocupação do território, processos naturais e cultura.

\footnotetext{
28 “Na primeira edição do Gardens in the Modern Landscape, Tunnard atacaria o 'misto de estilo' do século XIX sem registrar como eles ocorreram ou que pletora de estilos representou. No prefácio de sua segunda edição ele argumenta pelo ecletismo de estilos, ainda sem parar para perguntar sobre suas bases culturais, ou determinação...". HUNT, op cit, p 295.

29"As idéias de Tunnard explodem os cânones das artes dos jardins aceitos no século XIX bem como os resíduos pinturescos da Inglaterra, e a explosão reverbera através do Atlântico. NECKAR, in TRIEB, op cit, p144.
} 
Lawrence Halprin gradua-se em Plant Sciences, Botânica, em 1939, e em Landscape Architecture em 1943 por Harvard, e se confessa devedor de Tunnard ${ }^{30}$. Após a $2^{\mathrm{a}}$. Grande Guerra muda-se da costa oeste para a leste dos Estados Unidos e apresenta em seus escritos a clara pretensão de investigar a natureza do espaço moderno, compreendido como relação entre pessoas e meio ambiente. Um depoimento que torna essa questão mais aparente é o realizado por Halprin e publicado na revista Process Architecture, número 4: "Comecei com trabalhos em que as relações eram personalizadas: jardins e casas. Depois procurei expandir e ligar - grupos de casas, vilas pequenas, shopping centers. Com o passar do tempo a escala se amplia e a questão passa a ser: como pessoas, em regiões podem viver juntas sem degradar o ambiente que habitam. (...). Eu sempre senti que o design é um processo de total envolvimento e não algo puramente visual. Esse processo para mim tem sido sempre relacionado aos resultados" 31.

Há no modo como Halprin desenvolve seus projetos uma intensa cumplicidade com a questão cidade ${ }^{32}$. A ênfase à relação entre vida pública e meio ambiente tem como uma de suas diretrizes a questão da participação. No desenvolver dos projetos, o envolvimento de outros profissionais e especialmente do usuário é fundamental para a estratégia, ele é a razão de ser do processo, apresentando uma nova lógica na realização de projetos.

Também esse autor parece pretender dar continuidade à investigação do que venha a ser a construção de uma paisagem moderna, a modern landscape design, propondo uma metodologia que representa uma crítica ao modo de compreensão da problemática das cidades desse período. Seu processo de projeto está baseado em sistemas de mobilidade ${ }^{33}$, que são diagramas não lineares e sistêmicos, peças gráficas que expressam 0 movimento e o refletem acerca deles quantitativa e qualitativamente. Segundo o autor, são a própria definição

\footnotetext{
30 "Esse livro foi uma revelação - como um raio - relembra Halprin. (...). Argumentando pela simplicidade e integração de propósitos estéticos, funcionais e sociais no planejamento da terra em qualquer escala." WALKER and SIMO, op cit, p 149.

31 Revista PROCESS ARCHITECTURE, número 4, Lawrence Halprin, p 10.

32 Lewis Mumford é referencia fundamental para Halprin que procura atualizar um dos ideais do crítico e escritor - a cidade como um lugar no qual as pessoas realizam seu potencial criativo. WALKER and SIMO, op cit, p 149.

33 HALPRIN, Lawrence. R.V.P.S. Cycles. Creative Processes in Human Environment. New York : George Braziler, Inc,1969.
} 
do meio-ambiente: apenas após compreender e expressar o movimento poderá o meio ambiente, 'envelope' no qual o movimento se dá, ser projetado.

Toda a questão do meio ambiente é um decisivo ponto de inflexão no campo de atuação da Arquitetura da Paisagem, despertando diferentes alternativas metodológicas em seus expoentes. A ciência da ecologia e os métodos científicos relacionados à sistematização de informações tornam as produções mais complexas e implicam na interdisciplinaridade da profissão. As bases de dados agora reúnem regiões e territórios.

Projetar a paisagem passa a ser, a partir dessa perspectiva, descobrir meios que sejam capazes de articular essas informações: da interpretação de cartas com dados físicos, informações ambientais diversas, da vida animal existente, lençóis freáticos, às alternativas de desenvolvimento e usos pensados para a área; tudo é cúmplice da síntese que propõe o melhor modo de ocupar aquela região. E esse melhor implica numa idéia de beleza que imediatamente retoma a questão original: o desvendamento da relação que se estabelece entre natureza e artifício.

lan McHarg é personagem referencial da mudança em pauta, escrevendo em 1969 um livro que se tornou referencial à Arquitetura da Paisagem ${ }^{34}$. 0 percurso de McHarg desde a poluída Glasgow onde cursa o College Art, até Harvard, onde, entre 1946 e 1950, obtém dupla graduação em Landscape Architecture e Planning Arquitetura da Paisagem e Planejamento Urbano - inclui, durante todo o primeiro ano, aulas interdisciplinares. McHarg também fora aluno de Walter Gropius - e já no período lamenta a visão que certos modernistas têm do meio-ambiente, sua referência Moderna é Louis Kahn e a poética do espaço e da luz.

Em 1957, discursando à NCILA (National Conference on Instruction of Landscape Architecture), afirma: "Estamos no campo das artes e não devemos duvidar disso. O que perseguimos é um senso de poesia na paisagem, um enlevo que enriquece a vida das pessoas que se movem nele". 35 Para McHarg aquilo que comanda o processo de criação dessa poesia mencionada é a natureza, palavra que o autor utiliza de modo

\footnotetext{
34 McHARG, lan. Design with Nature. Philadelphia : Falcon Press, 1969. 1969 é também o ano em que o ato de Políticas Nacionais do MeioAmbiente inaugura a política do Meio-Ambiente nos Estados Unidos.

35 McHARG apud Journal of the Institute of Landscape Architects, November 1957, p.4.
} 
indistinto a ecologia, ciência nova na descrição do mundo e da vida: ela opera como diretriz, fonte de verificação e obtenção de verdade.

É mesmo o estatuto da relação entre natureza e arte que passa por uma mudança. O Belo ao qual se refere McHarg vem do ecologicamente correto, emudecendo outras fontes criativas. Ao mesmo tempo, ao pensar na arte em termos da relação homem/meio-ambiente, pretende afirmar uma nova filosofia, um novo Humanismo alicerçado em conexões vitais que passam a ser reveladas através de metáforas operadas pelos Projetos da Paisagem. Essas metáforas, cuja inspiração aparece a partir do próprio lugar 36 , oferecem-nos, segundo sua argumentação, a chance de pensar ocupações e planos que contrariam lógicas eminentemente econômicas. Sua fala reafirma uma arte que transparece quando a ciência se realiza.

A escolha desses autores para alicerçar um possivel contraponto à fala de Hunt acerca da mudez teórica na arquitetura da paisagem procura ilustrar o que parecem ser as duas principais correntes às quais se associam as investigações atuais na área; a saber, a questão da ênfase ao processo ancorado à questão da participação; e a investigação e coleção de dados relacionados ao meio-ambiente, do qual emerge o assunto que está na ordem do dia: a questão da sustentabilidade, em seus diversos níveis, do ecológico ao paisagístico, passando pelo social e econômico financeiro.

parte final

O esforço da historiografia recente, com ênfase a partir da década de 80, mas que se anuncia já nos finais da década de 60 , procura sustentar a dupla chave que apresenta convivências inusitadas, ao mesmo tempo em que mergulham nas particularidades de um lugar, para extrair daí aproximações e deserções em relação ao universal aceite 37 .

\footnotetext{
36 WALKER \& SIMO, p276.

37 Os colóquios sobre Landscape Architecture realizados pela Dumbarton Oaks, ligada à Universidade de Harvard, atestam encontros nos quais, eleita uma temática observa-se uma seleção de artigos ligados a ela. Ver especialmente o Colloquium no. XIII: Garden History; Issues,
} 
São livros que mergulham mais profundamente em especiais lugares, ou projetos, procurando extrair dali toda uma cadeia de relações que pretende construir um vínculo mais elaborado entre paisagem e cultura, ao mesmo tempo em que tornam visíveis através desses desenvolvimentos, o problema das generalizações e estilos. 0 rigor pretendido por John Dixon Hunt é uma das marcas dessa historiografia.

O livro editado por Simon Swaffield 38, Theory in Landscape Architecture, é prova dos esforços empreendidos na direção de uma varredura do que já se realizou enquanto elaboração teórica para a arquitetura da paisagem. 0 instigante livro de Steven Krog, Creativ Risk Taking, que participa dessa mostra reproduz aquilo que parece ser o aporte necessário para ensaiar a parte final desse trabalho, e que se relaciona fundamentalmente à criação e como esta se estabelece, uma vez mais, entre natureza e artifício.

O livro nasce de uma questão: Por que são tão poucas as paisagens elaboradas artificialmente que não podemos deixar de tomar conhecimento, que devemos ver? E por que elas geralmente não nascem das mãos de paisagistas, (landscape architects), mas dos arquitetos de edificação, ou dos chamados artistas da terra, que produzem a Land Art?

Como hipótese de resposta, Krog associa essa ausência de participação dos paisagistas na realização das paisagens memoráveis, ao processo de projeto próprio do paisagismo, design process, herdado dos grandes nomes da arquitetura da paisagem. O design process é estratégia conhecida dos praticantes e significa a utilização de expedientes que reúnem dados, percepções e questões do lugar de intervenção. Como metodologia não apresenta respostas, apenas operacionaliza informações 39.

O campo disciplinar, especialmente o americano que engendrou essa lógica do design process, através de figuras como Eckbo, Halprin e McHarg, entre outros, tornou crescentemente complexas a apresentação desses

Approaches, Methods, edited by John Dixon Hunt e o Colloquium no. XVIII: Nature and Ideology; Natural Garden Design in the Twentieth Century, edited by Joachim Wolschke-Bulmahn, ambos publicados pela Dumbarton Oaks, Washington, D.C., 1989 e 1995, respectivamente.

38 SWAFFIELD Simon, editor. Theory in Landscape Architecture, a reader. Philadelphia : University of Pennsylvania Press, 2002.

39 "O design process geralmente produz mais informação que consome, e infelizmente nunca produz uma grama de insight. Isso não é culpa do processo. Ele nunca nos prometeu solução aos nossos problemas - apenas os meios pelos quais podemos realizar reflexões lógicas. Em nossa pressa, confusão ou indolência, não negligenciamos o fato de que o processo colapsa quando percebemos o assombroso abismo estabelecido entre o diagrama funcional e o desenvolvimento de projeto". KROG apud SWAFFIED, op cit, p 59. 
diagramas que reuniam toda a informação possível de ser disposta sobre um lugar. 0 próprio Halprin reconheceria o dilema acerca dos diagramas: eles por si não respondiam a nada, não apresentavam a solução. E por mais que se tentasse distinguir uma metodologia, o final do caminho não era visível; por mais que parecesse que se constituía uma teoria, ela não apresentava disposições sobre a etapa final de maneira clara. Esse desvio, ou resposta não completa devinha da própria qualidade do que se tinha em mãos: uma resposta para além dos diagramas, tratava-se do momento da criação artística. Nesse sentido, a crítica elaborada por John Dixon Hunt em relação à mudez é não só pertinente, mas desafiadora.

O design process, processo de projeto difundido pelo campo disciplinar, deve ser compreendido como expediente potencialmente capaz de gerar ilusão de que cumprida todas as etapas, realizadas todas as fases, o projeto aparecerá; contudo esse expediente não é mais que uma técnica, estratégico, mas não a razão de ser da arquitetura da paisagem ${ }^{40}$.

A proposta de Steven Krog torna visível uma arquitetura da paisagem pelo que potencialmente a distingue e define: sua qualidade estética. Qual seria o novo caminho, melhor dizendo, qual seria a reconquista? Essa resposta toca em questões abordadas no capítulo sobre Paisagem: reativar valências estéticas significa entrar em contato uma vez mais com essa dimensão, esse liame que tece a relação homem/natureza pelo artifício.

Implica também, no que diz respeito a uma prática que participa da construção de espaços livres, num potencial cliente, ou usuário, o que insere novas questões naquela relacionada à investigação artística. 0 dilema que se apresenta diz respeito a propor inventivamente questões reconhecidas pela sociedade a partir de símbolos culturalmente conhecidos, ou lançar mão do inusitado, do que subverte, daquilo que endereçado ao novo evoca mais complexos significados, e com isso correr riscos. Krog diferencia os projetos inventivos, que operam com símbolos familiares, dos criativos. A criação desenvolve alta atenção e exige maior esforço em sua compreensão.

40 "O processo metodológico dedutivo pode satisfazer os anseios dos planejadores funcionalistas. Mas a arquitetura da paisagem é uma mestra de maiores demandas. Essa é a arquitetura da paisagem da experiência, não dos objetos". KROG apud SWAFFIED, op cit, p 60. 
Sua proposta é a visualização de uma atividade que busca propor à sua audiência investigar os limites físicos e psicológicos de sua própria percepção. (...) Para acomodar necessidades contemporâneas, uma totalidade de novas combinações e proposições de significado serão necessárias ${ }^{41}$. Nesse sentido há necessidade de estudar e debater questões estéticas ${ }^{42}$, projetando uma nova agenda de significados ${ }^{43}$.

O que deve ser buscado pelo artista não é um objeto, mas uma experiência ${ }^{44}$, esse é o ponto central: a criação envolve uma ausência, uma falta e implica numa angústia.

A criação para Longino no século I implicava na suspensão da razão ${ }^{45}$, num estado de espírito que inspira a visão, que significa arrebatamento, um transe, que vê além. Se não se tem essas visões seria preciso trabalhar a imaginação que tira o ser do não ser, inventar a visão. Em parte é isso que o texto de Longino defende: seria possível sensibilizar o espírito, prepará-lo a perceber, conspirar pela visão. A metáfora tornava possível o salto.

Também Ruskin afirmava no século XIX que o verdadeiro artista tinha no poder da invenção algo de profeta, parte do que representa sequer apareceria em sua representação; invocando a tradição da metáfora artística, sustentada por seu espelhamento na Natureza, guia do artista.

Contemporaneamente artistas rejeitam a idéia da metáfora como meio. Frank Stella prega mesmo sua eliminação; Mary Gordon argumenta em favor da expressão da presença do real, nada além disso interessa. Todas essas questões estão endereçadas e abertas àqueles que hoje projetam e criam os lugares ${ }^{46}$.

\footnotetext{
41 KROG apud SWAFFIED, op cit, p 62 e 63.

42 "Bernard Tschumi parece haver encontrado a soluçãp em uma problemática hiperconceitual inspirada pela leitura de Barthes, Deleuze, ou Derrida, formalizando em uma linguagem que é menos vegetal que tecnológica. (...). Esse admitidamente ambicioso complexo [La Villete] apresenta a si como uma antecipação. A antecipação de um século XXI (...). Uma página foi virada". LE DANTEC, Denise, and LE DANTEC, JeanPierre. Reading the French Garden \; Story and History. Cambridge, Massachussets / London, England: The MIT Press, 1990, (1987).

43 HUNT, op cit, p 290.

44 "Eu acredito que para a maioria dos artistas hoje (...) o fazer arte é uma busca, um procurar por aquilo que o artista não tem, não encontra, e deseja a existência." KROG apud SWAFFIED, op cit, p 60

45 LONGINO, op cit, p 27.

46 “Se nós abandonarmos o design process como fonte de inspiração, mas o mantivermos como reunião de informações, isso pode ser catártico - e assustador. (...) Então qual é o 'novo meio' para se pensar? Eu defendo que a arte da arquitetura da paisagem envolve um simples reconhecimento, ou sutil criação e transformação de uma 'presença' (para utilizar um termo de Robert Irwin) do lugar; com o qual, ou talvez através, da minimização, ( Frank Stella clamaria pela eliminação) da metáfora". KROG, apud SWAFFIELD, op cit, p 60. Ainda sobre os termos presença e metáfora diz a nota 4 da mesma página: "Presença" é a resposta intelectual e emocional à combinação temporal e especial
} 
Quando o filósofo contemporâneo Jean-François Lyotard investiga a possibilidade de existência de um pensamento sem o corpo ele se vê às voltas com esse antigo problema de distinção entre a natureza e o artifício. 0 ensaio, Se pudermos pensar sem corpo ${ }^{47}$, realiza-se tendo a perspectiva do futuro inexorável, quando o sol desaparece e o humano se encerra.

Pondo em xeque a falácia de que é só uma questão de tempo para que a inteligência artificial reproduza de fato toda a qualidade humana que pode ser lançada a uma sobrevida no espaço, temos algumas especificidades apontadas e a impossibilidade de mimetizá-las: Como Husserl mostrou, o pensamento ausculta um horizonte, visa um noema, um tipo de objeto, uma espécie de monograma não conceitual que Ihe fornece configurações intuitivas ${ }^{48}$, a esse quadro associa Lyotard o pensamento kantiano acerca do juízo reflexivo: o pensamento não se dirige por regras de determinação de dados, mas é capaz mesmo de elaborar regras a partir de resultado reflexivos. No processo de pensamento não ocorrem apenas processos analógicos, mas pensamentos que processam analogias que escapam à simples lógica.

A questão de fundo é a da produção do pensamento - e ela se liga a uma aparente suspensão da regra presente na linguagem: para que o novo sobrevenha são necessários lapsos na plenitude da intelecção.

Kant já havia vislumbrado na imaginação seu potencial efeito libertador em sua análise sobre o trabalho da imaginação inerente ao gosto e ao prazer do belo: os elementos fornecidos pela sensibilidade são tratados livremente pelo espírito, no entanto a imaginação dá o que pensar ao espírito, mais do que o trabalho conceitual. A apreensão estética das formas só é possível se se renunciar a toda a pretensão de dominar o tempo com uma síntese conceitual (...) [trata-se antes] da aptidão para deixar aparecer as coisas da forma como se apresentarem ${ }^{49}$.

características do lugar. "Metáfora" pretendeu significar a extensão com a qual o trabalho 'parece', ou 'se refere a', algo fora de si, com ou sem intenção por parte do artista.

47 LYOTARD, Jean-François. O inumano, considerações sobre o tempo. Lisboa : Editorial Estampa, 1989.

48 LYOTARD, op cit, p 24.

49 LYOTARD, op cit, p 41. 
Não se trata de algo que acorra sem dor. Suspender a regra é afastar-se de si, no sentido do conhecido, para que desobstruído o corpo e o espírito possam perceber. Daí a afirmação de Lyotard de que pensar é sofrer, porque o pensamento não conduz necessariamente à solução, é antes o indeterminado, a atividade que contraria a identificação, e que, no entanto, participa dela. Essa parece ser uma qualidade fundamental da criação com a qual lidamos.

O desafio seria criar situações que provoquem esses momentos, e vivê-los.

São Carlos, junho de 2008. 
AB'SÁBER, Aziz. Os domínios de Natureza no Brasil - potencialidades paisagísticas. São Paulo : Ateliê Editorial, 2003.

ABBAGNANO, Nicola. Dicionário de Filosofia. São Paulo : Mestre Jou, 1982.

ADORNO, Theodor W. O ensaio como forma. Org. Gabriel Cohn; coord.Florestan Fernandes. São Paulo : Ática, 1994.

ALBA, Antonio. El Espacio del Arte em la Construccion de la Ciudad Moderna, in Ciudad y Territorio, enero / marzo, 1987.

ALBERTI, Leon Battista. Da Pintura. Campinas : Unicamp, 1999.

ARENDT, Hanah. A Condição Humana.Rio de Janeiro : Forense Universitária, 2005.

ARGAN, Giulio C. A História da Arte como História da Cidade. São Paulo : Martins Fontes, 1992.

ARGAN, Giulio Carlo. Arte Moderna. São Paulo : Companhia das Letras, 1992.

AZEVEDO, Ricardo Marques. Antigos Modernos: Contribuição ao Estudo das Doutrinas Arquitetônicas, (séculos XVII e XVIII). Tese de Livre Docência apresentada ao Departamento de História da Arquitetura e Estética do Projeto. Faculdade de Arquitetura e Urbanismo, Universidade de São Paulo, revisão de abril de 2007.

AZEVEDO, Ricardo Marques. Arte e Natureza, in Nefelomancias, ensaios sobre as artes dos romantismos, texto do autor, janeiro de 2008.

BERLIN, Isaiah. Las Raíces del Romanticismo. Conferências A.W. Mellon em Belas Artes, 1965. Madrid : Taurus/Pensamiento, 2000.

BROWN, Jane. El Jardín Moderno. Barcelona : Gustavo Gili, 2000.

CAUQUELIN, Anne. A Invenção da Paisagem. São Paulo : Martins Fontes, 2007.

CHOAY, Françoise. A Regra e o Modelo. Perspectiva : São Paulo, 1980.

CLIFFORD, Derek . A History of Garden Design. London : Faber \& Faber, 1962.

COFFIN, David. English Garden - Meditation and Memorial. Princenton (New Jersey): Princenton University Press, 1994.

CORBIN, Alain. O território do Vazio. A Praia e o Imaginário Ocidental. São Paulo : Companhia das Letras, 1989.

CREESE, Walter L. 'The Boston Fens', in The Crowning of the American Landscape. Eight Great Spaces and their Buildings. Princenton University Press : Princenton, New Jersey, 1985. 
DAL CO, Francesco et alii. De los Parques a la región. Ideologia progressista y reforma de la ciudad americana. In La Ciudad Americana, da guerra civil ao New Deal. Barcelona : Gustavo Gili, 1975.

DEBUS, Allen G. Man and Nature in the Renaissance. Cambridge, NY : Cambridge University Press, 1990, (1978).

ECKBO, Garret. Landscape for Living, Architectural Record : New York, 1950.

FERNÁNDEZ, BOLET e ESTEVA-GRILLET. Ideas de Humboldt sobre a Paisagem, in. in Paisagem e Arte, org Heliana Angoti Salgueiro. São Paulo : CBHA / CNPQ / Fapesp, 2000.

FISHER, Irwing. Frederick Law Olmsted and the City Planning Moviment. Michigan : Columbia University /UMI Research Press, 1976.

FRANCIS, Mark \& HESTER, Rando, editores. The meaning of gardens, Massachussets: MIT Press, 1990.

GARCIA, Celso. La Naturaleza y el Hombre, (seleciones de John Ruskin). Madrid : Nueva Biblioteca Filosofica, 1933.

GOMBRICH, Ernst. "Nature and Art as Needs of the Mind", (1981) in The Essential Gombrich - Selected Writings on Art and Culture, edited by Richard Woodfield. London: Phaidon Press, 1996

GRESE, Robert E. Jens Jensen, Maker of Natural Parks and Gardens. The John Hopkins University Press: Baltimore/London, 1992.

GRIMAL, Pierre. L'Art des Jardins. Paris : Presses Universitaires de France, 1974.

GRIMAL, Pierre. Les Jardins Romains. Paris : Presses Universitaires de France, 1967.

GUSDORF, George. Le savoir romantique de la natur. Payot : Paris, 1985.

HANSEN, João A. A temporalidade na cultura contemporânea. In Conversas no Ateliê, palestras sobre Artes e Humanidades. Direção Vera M. Pallamin, coordenação Joaci Furtado. São Paulo : FAU - USP, 2002.

HIPPLE Jr, Walter John. The Beautiful, The Sublime, \& The Picturesque in Eighteenth - Century British Aesthetic Theory. New York : The Southern Illinois University Press, 1957.

HOLDEN, Robert. New Landscape Design, Barcelona : Gustavo Gili, 2003,

HUMBOLDT, Alexander von. Cosmos, a Sketch of a Physical Description of the Universe. Baltimore and London : The Johns Hopkins University Press, 1997, (1845), vol II.

HUNT, John Dixon and WILLIS, Peter, editors. The Genius of the Place. The english Landscape Garden 16201820. The MIT Press : Cambridge/London, 2000, (1988).

HUNT, John Dixon, editor. Colloquium no. XIII: Garden History; Issues, Approaches, Methods. Washington, D.C.: Dumbarton Oaks, 1989. 
HUNT,John Dixon. Gardens and the Picturesque. Studies in History of Landscape Architecture, The MIT Press : Cambridge/Massachussets, 1992.

IMBERT, Dorothée, The Modernist Garden in France. Yale University Press : New Haven and London, 1993.

JELLICOE, Geoffrey \& Susan. The Landscape of Man. London : Thames and Hudson, 1995

JUSTINO, Maria José. Criticar é... entrar na crise. In GONÇALVES, Lisbeth R. e FABRIS, Annateresa. Os Lugares da Critica de Arte. São Paulo : Imprensa Oficial, 2005.

KOSTOF, Spiro. The elements of Urban Form Through History. London: Bulfinch Press Book, 1999 (1992).

KOYRÉ, Alexandre. Do Mundo Fechado ao Universo Infinito. Rio de Janeiro: Forense, 1979.

LAURIE, Michael. Intruducción a la architectura del paisaje. Barcelona : Gustavo Gili, 1983

LE DANTEC, Denise and Jean Pierre. Reading the French Garden: Story and History. Cambridge : MIT Press, 1990.

LE GOFF, Jacques e SETA, Cesare de. A Ciudad y las Murallas, Catedra : Madrid, 1989.

LEENHARDT, Jacques (org). Nos Jardins de Burle Marx. São Paulo : Perspectiva, 2000.

LENOBLE, Robert. História da Idéia de Natureza. Edições 70 : Lisboa, 1969.

LONGINO, Pseudo Longino ou Dionísio. Do Sublime. São Paulo : Martins Fontes, 1996.

MARTINET, Marie-Madeleine. Art et Nature en Grande-Bretagne. De I'harmonie classique eu pittoresque du premier romantisme, 17e - 18e siècles. Paris : Aubier-Montaigne, 1980.

MARTINS, Luciana de Lima. A Pintura inquieta da Paisagem Tropical, in 10.Colóquio Internacional de História da Arte: Paisagem e Arte. Coordenação Heliana Angoti Salgueiro. São Paulo : CBHA/CNPq/FAPESP, 2000.

MATOS, Olgária. A Escola de Frankfurt: Iuzes e sombras do iluminismo. São Paulo : Moderna, 1993.

MCHARG, lan. Design with Nature. Philadelphia : Falcon Press, 1969.

MERLEAU - PONTY, Maurice. A Natureza. São Paulo : Martins Fontes, 2000.

MERLEAU - PONTY, Maurice. O Olho e o Espírito. São Paulo : Cosac\&Naify, 2004.

MERLEAU-PONTY, Maurice. 'Em toda e em nenhuma parte'; in Textos Selecionados, coleção Os Pensadores. Org. Marilena Chauí. São Paulo: Abril Cultural, 1984.

MONBEIG, Pierre. Ensaios de Geografia Humana Brasileira. Rio de Janeiro : Livraria Martins, 1940

MORRIS, A.E.J. Historia de la forma urbana - desde sus orígenes hasta la Revolución Industrial. Barcelona : Gustavo Gili, 1984. 
MOSSER, Monique. 'Paradox in the Garden: A Brief Account of Fabriques', in The History of Garden Design, the Western tradition from Renassance to the present day. Editores MOSSER, Monique and TEYSSOT, George. Thames \& Hudson : London, 1991.

MOSSER, Monique and TEYSSOT, George, editors. The History of Garden Design, the Western tradition from Renassance to the present day

MUNFORD, Lewis. A Cidade na História - suas origens transformações e perspectivas. São Paulo : Martins Fontes / UNB, 1982.

NEGT, Oskar. 'Espaço Público e Experiência', in Cidade e Cultura, esfera pública e transformação urbana. São Paulo : Editora Estação Liberdade, 2002.

OLMSTED, Jr. \& KIMBALL, Theodora, editors. Forty Years of Landscape Architecture: Being the Professional Papers of Frederick Law Olmsted, senior - Landscape Architect, 1822-1903. Volume 2: Central Park as a Work of Art and as a Great Municipal Enterprise, 1853-1895. New York and London : G.O.Putnam's sons / The Knickerboker Press, 1928.

PALLAMIN, Vera M. Arte Urbana - Aspectos Contemporâneos. In Sinopes São Paulo, no.22, p24 a 32, dezembro de 1994.

PALLAMIN, Vera M. Arte Urbana : Região Central (1945:1998): obras de caráter temporário e permanente. São Paulo : Annablume: FAPESP, 2000.

PALLAMIN, Vera M. Arte Urbana como Prática Crítica, in Cidade e Cultura, esfera pública e transformação urbana. São Paulo : Editora Estação Liberdade, 2002.

PALLAMIN, Vera M. Cidade e Cultura: esfera pública e transformação urbana. São Paulo : Estação Liberdade, 2000.

PEVSNER, Nikolaus. Estudios sobre Arte, Arquitectura y Diseño; del Manierismo al Romanticismo, era Victoriana y Siglo XX. Barcelona : Gustavo Gili, 1983.

PLINY, THE ELDER, Natural History, a selection. London : Penguin Books, 1991.

Revista PROCESS ARCHITECTURE, número 4, Lawrence Halprin.

ROBINSON, Sidney, K. Inquiry into the picturesque. University of Chicago Press: Chicago \& London, 1991.

ROGER, Alan. 'La Naissance du Paysage em Occident', in Paisagem e Arte, org Heliana Angoti Salgueiro. São Paulo : CBHA / CNPQ / Fapesp, 2000.

ROPER, Laura Wood, FLO, A Biography of Frederick Law Olmsted, The Johns Hopkins University Press : Baltimore \& London, 1983, (1973).

RYCKWERT, Joseph. A Sedução do Lugar. São Paulo : Martins Fontes, 2005. 
SALGUEIRO, Heliana A. Pierre Monbeig: A Paisagem na Óptica Geográfica, in Paisagem e Arte, org Heliana Angoti Salgueiro. São Paulo : CBHA / CNPQ / Fapesp, 2000.

SALGUEIRO, Heliana A. org. Paisagem e Arte, org Heliana Angoti Salgueiro. São Paulo : CBHA / CNPQ / Fapesp, 2000.

SANTOS, Milton. A Natureza do Espaço. Técnica e Tempo. Razão e Emoção. São Paulo : Edusp, 2002.

SCHAMA, Simon.Landscape and Memory. New York : Vintage Books, 1995.

SCHILLER, Friedrich. A Educação Estética do Homem. São Paulo : lluminuras, 1995.

SCULLY, Vincent. American Architecture and Urbanism. New York: Holt, Rinehart and Winston, 1969.

SEGALA, Lygia. A natureza Virgem e a Paisagem Humana no Projeto Fotográfico de Victor Frond, in Paisagem e Arte, org Heliana Angoti Salgueiro. São Paulo : CBHA / CNPQ / Fapesp, 2000.

SILVA, Jonathas Magalhães Pereira da Silva. O Papel da Disciplina de Paisagismo na Formação de Arquitetos Urbanistas, Tese Doutorado, FAU - USP, 2005.

SILVESTRI, Graciela y ALIATA, Fernando. El Paisaje como Cifra de Armonía - relaciones entre cultura y naturaleza través de la mirada paisajística. Buenos Aires : Nueva Vision, 2001.

SIMMEL, George. Filosofia da Paisagem, in O Indivíduo e a Liberdade, Ensaios de Crítica e Cultura, Barcelona, 1986.

SIMO, Melanie. 100 Years of Landscape Architecture. ASLA Press: Washington DC, 1999.

SPIRN, Anne W. O Jardim de Granito, a natureza no desenho da cidade. São Paulo : Edusp.

STAROBINSKI, Jean. Jean-Jacques Rousseau: a transparência e o obstáculo; seguido de sete ensaios sobre Rousseau, São Paulo : Companhia das Letras, 1991.

STEENBERGEN, Clemens/ REH, Wouter. Colaboração de SMIENK, Gerrit. Arquitectura y Paysaje - La Proyectación de los Grandes Jardines Europeus. Barcelona : Gustavo Gili

SUTTON, S. B. Civilizing American Cities. A Selection of Frederick Law Olmsted's Writings on City Landscapes. The MIT Press : Cambridge, Massachussets and London, England, 1971.

MCLAUGHLIN, Charles Capen, editor chef. The Papers of Frederick Law Olmsted, volume I, The Formative Years(1822 - 1852. The Johns Hopkins University Press : Baltimore \& London, 1977.

MCLAUGHLIN, Charles Capen, editor chef. The Papers of Frederick Law Olmsted, Volume III, Creating Central Park, (1857-1861). McLAUGHLIN, Charles Capen, editor chefe. The John Hopkins University Press : Baltimore and London, 1983. 
SCHUYLER, David and CENSER, Jane, editors. The Papers of Frederick Law Olmsted, volume IV, The Years of Olmsted, Vaux \& Company; 1865-1874. The Johns Hopkins University Press : Baltimore and London, 1992.

THOMAS, Keith. O Homem e o Mundo Natural - as mudanças de atitudes em relação às plantas e aos animais (1500 - 1800). São Paulo : Companhia das Letras, 1988.

TRIEB, Marc. Axioms for a Modern Landscape Architecture, in TRIEB, Marc, editor. Modern Landscape Architecture: A Critical review. 1993.

TRIEB, Marc. Modern Landscape Architecture: A Critical Review. Cambridge, Massachussets: The MIT Press, 1993.

TUNNARD, Christopher. Gardens in the Modern Landscape. London : The Architectural Press, 1938, $1^{\text {a }}$. Edição. New York : Charles Scribner's Sons, 1948, 2ª edição, revisada.

WALKER, Peter \& SIMO, Melanie. Invisible Gardens, The search for Modernism in the American Landscape. Cambridge, Massachussets : MIT Press, 1994.

WILLIAMS, Raymond. O Campo e a Cidade, na história e na literatura. São Paulo : Companhia das Letras, 1989.

WOLSCHKE-BULMAHN, Joachim. Colloquium no. XVIII: Nature and Ideology; Natural Garden Design in the Twentieth Century, Washington, D.C.: Dumbarton Oaks, 1995.

imagens de abertura dos capítulos

cap. I - Ermenonville, gravura da sepultura de Rousseau, (1808), in HUNT \& WILLIS, p 42.

cap. II - Harmonia macrocosmi cum microcosmi, de autoria de Tobias Schütz, (1654), in DEBUS, p 28.

cap. III - Empedocles, de autoria de Salvatore Rosa, in SCHAMA, p 455.

cap. IV - Frederick Law Olmsted, in The paper of Frederick Law Olmsted, volume I, imagem contra-capa.

cap. V - La Fosca, Seafront Promenade, Pálamos, Espanha, projeto de autoria de Joseph Fuses e Joan Viader, in TOPOS, The International Review of Landscape Architecture and Urban Design, n 36, 2001, pp 67a 69. 
fig. 1 - Hypnerotomachia ou Sonho de Poliphilo, in SCHAMA, p 278.

fig. 2 - Exposição Internacional de Artes Decorativas e Industriais Modernas - Paris 1925, in IMBERT, p 31.

fig. 3 - Árvores de concreto de Jan e Joel Martel nos jardins de Mallet-Stevens, in IMBERT, p 38.

fig. 4 - Fonte da juventude miniatura da De Sphaera, Biblioteca Estense, Modena in MOSSER \& TEYSSOT, p 89.

fig. 5 - Detalhe do Central Park de autoria de Frederick Law Olmsted e Calvert Vaux, in SCHAMA, p 568.

fig. 6 - propriedade de William Sandy, desenho de Jan Kip (1720), in PEVSNER, pp 112 e 113.

fig. 7 - Twickenham, propriedade de Alexander Pope, in PEVSNER, pp 104 e 105.

fig. 8 - Desenho atribuído à William Kent (1734), in HUNT \& WILLIS, p 23.

fig. 9 - Projeto para os domínios de Versailles, in LE DANTEC, p 152.

fig. 10 - Pintura de William Gilpin em Três Ensaios (1792) mostrando a diferença entre uma cena sem elaboração e outra com composição pinturesca, in HIPPLE, entre pp 202 e 203.

fig. 11 - Contraponto entre composição pinturesca e representação segundo perspectiva de Capability Brown, in HUNT \& WILLIS, p 343.

fig. 12 - Pintura de Salvatore Rosa (1650), in HUNT \& WILLIS, p 14.

fig. 13 - Birkenhead Park, (1843), Joseph Paxton, in KOSTOF, p 171.

fig. 14 - Central Park, in MCLAUGHLIN, editor, The papers of Frederick Law Olmsted, volume 2, p 118.

fig. 15 - Prospect Park, in SCHUYLER \& CENSER, editors, The Papers of Frederick Law Olmsted, volume IV, pp 666 e 667.

fig. 16 - Tompkins Park, (1870) e Washington Park, (1867), in SCHUYLER \& CENSER, editors, The Papers of Frederick Law Olmsted, volume IV, pp 396 e 203.

fig. 17 - Fens, (1878), in CREESE, p 185.

fig. 18 - Fens, in CREESE, p 191.

fig. 19 - Sistema de parques de Boston, in CREESE, p 167.

fig. 20 - Riverside, (1869), in CREESE, p 219.

fig. 21 - Frederick Law Olmsted, fotografado por James Notman, (1893), http://www.americanlibrary.gov. 